
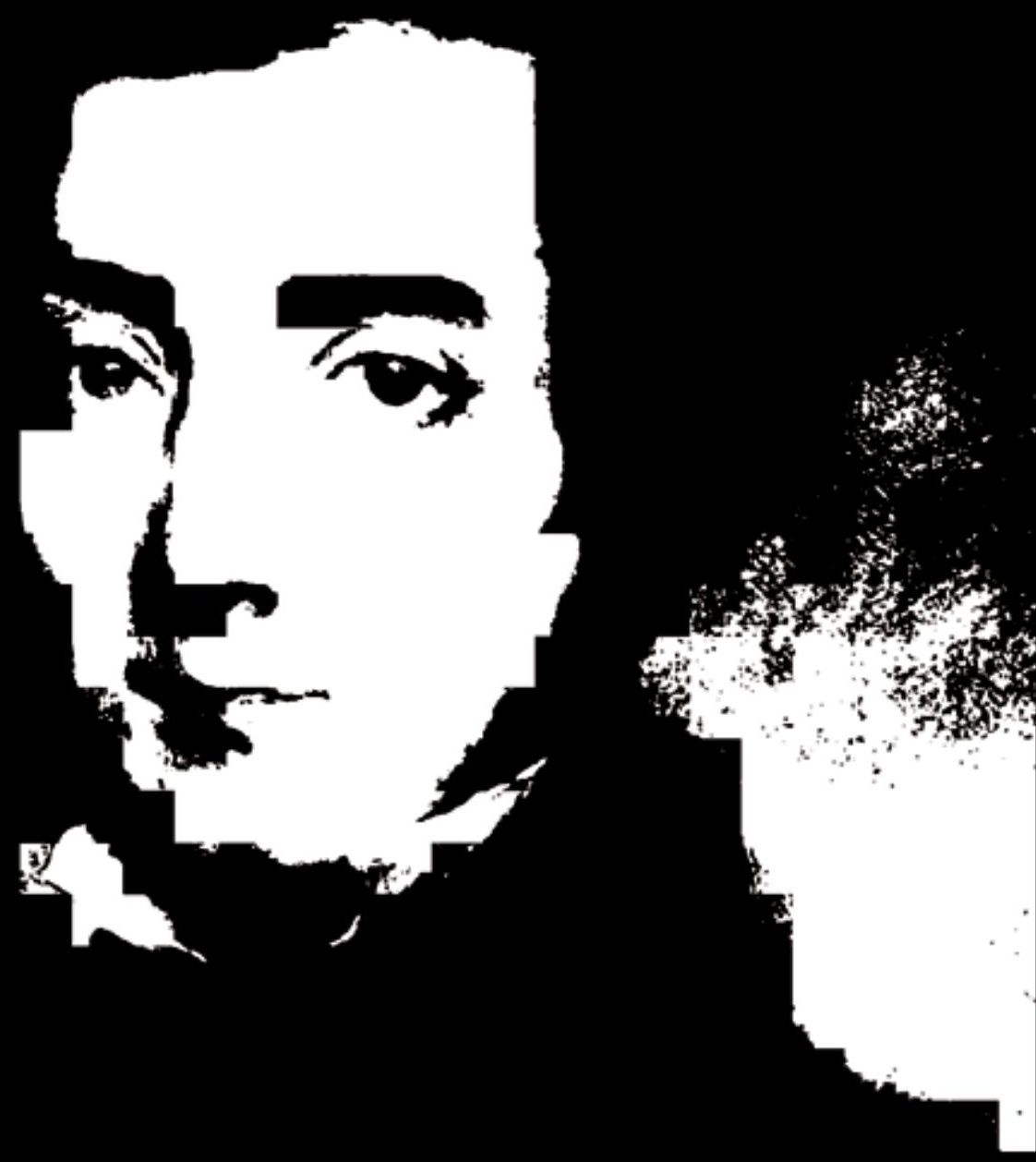

Tocqueville and Democracy

in the Internet Age

C. Jon Delogu 



\section{Tocqueville and Democracy in the Internet Age}





\title{
Tocqueville and Democracy in the Internet Age
}

\author{
C. Jon Delogu
}

\author{
() \\ OPEN HUMANITIES PRESS \\ An imprint of Michigan Publishing \\ University of Michigan Library, Ann Arbor
}


First edition published by OPEN HUMANITIES PRESS 2014

Freely available online at http://dx.doi.org/10.3998/ohp.12538666.0001.001

Copyright (C) 2014 C. Jon Delogu

This is an open access book, licensed under Creative Commons By Attribution Share Alike license. Under this license, authors allow anyone to download, reuse, reprint, modify, distribute, and/or copy their work so long as the authors and source are cited and resulting derivative works are licensed under the same or similar license. No permission is required from the authors or the publisher. Statutory fair use and other rights are in no way affected by the above.

Read more about the license at creativecommons.org/licenses/by-sa/3.0

Cover Art, figures, and other media included with this book may be under different copyright restrictions. Please see the Permissions section at the back of this book for more information.

ISBN-13 978-1-60785-303-9

OPEN HUMANITIES PRESS is an international, scholar-led open access publishing collective whose mission is to make leading works of contemporary critical thought freely available worldwide. Books published under the open humanities press imprint at Michigan Publishing are produced through a unique partnership between OHP's editorial board and the University of Michigan Library, which provides a library-based managing and production support infrastructure to facilitate scholars to publish leading research in book form. 


\section{Contents}

Introduction

I Tocqueville

1. Reading Democracy in America

2. Tocqueville's Commentators

\section{Democracy}

3. "Who controls the meanings of democracy and, thereby, its fate?"

4. Restore Previous Session

III In the Internet Age

5. Democracy Watch 2011

6. Democracy and the New Dignity 264

7. What Would Tocqueville Do? 288

$\begin{array}{ll}\text { Conclusion } & 304\end{array}$

Appendix 312

$\begin{array}{ll}\text { Bibliography } & 318\end{array}$ 

For Rose and Daniel... and in memory of

Kevin Boyle and Mohamed Bouazizi. 

"Has every other century been like this one? Has man always confronted, as he does today, a world in which nothing makes sense? In which virtue is without genius and genius without honor? In which the love of order is indistinguishable from the lust of tyrants? In which the sacred cult of liberty is confounded with contempt for the law? In which conscience casts but an ambiguous light on the actions of men? In which nothing any longer seems forbidden or allowed, honest or shameful, true or false?"

- Tocqueville, Democracy in America (from the Introduction)

"But when the intervals of darkness come, as come they must,- when the sun is hid and the stars withdraw their shining, - we repair to the lamps which were kindled by their ray, to guide our steps to the East again, where the dawn is."

- Ralph Waldo Emerson, "The American Scholar" 



\section{Introduction}

As the title indicates, this book is about a particular man, an idea, and the time period we live in. The man, Alexis de Tocqueville (1805-1859), was a French aristocrat. His name designates a place in Normandy whose people and soil he was linked to, like his father before him, by Old Regime ties of loyalty and mutual service. But he was born in the aftermath of the idealistic and bloody French Revolution under Napoleon's dictatorship and therefore had both an intense theoretical and a practical interest in the history of civil society and the workings of monarchy, aristocracy, and especially democracy. After existing as a term of derision for over two thousand years, ${ }^{1}$ democracy had become the name of both a form of government and a flourishing way of life in nineteenth-century America where he traveled for nine months in 1831 and 1832 to investigate this unexpectedly successful experiment in popular sovereignty.

Tocqueville is most remembered as the author of a two-volume study Democracy in America $(1835,1840)$. It is a digest of his observations about America and offers argued predictions about democracy's future prospects. It is a work that is still considered by many today, in the Internet age, to be "the best book ever written on democracy" 2 and "one of the wisest books ever written about us" [Americans]. ${ }^{3}$

Much has been written about Tocqueville, about his book on democracy, and about democracy in general since 1989, the roughly quarter century that I am calling the Internet Age, which also coincides with the post-Cold War era. ${ }^{4}$ The purposes and opinions of these recent studies vary greatly and can strike one as a confusing, formidable mass. The task of making sense of Tocqueville and democracy in the Internet age is further complicated by the fact that many commentators seem more interested in being a sun than a satellite and therefore not all that concerned by what others have to say. I have tried, like Tocqueville, to be a better listener, as well as a mediator between individuals who seem not to be talking to each other. The result is this book, an extended essay that 
proposes an open assessment of both Tocqueville and democracy in the Internet age and asks what the fortunes of both might be over the next few decades.

I first became interested in Tocqueville over a ten year period from 1995 to 2005 when I was teaching annual seminars on Emerson, Thoreau, Dewey, and William James to French students of English at public universities in Toulouse and later Lyon. Despite Tocqueville's aristocratic French origins, I noticed that he had many links to these four. He was only two years younger than Emerson (1803-1882), and he died the year Dewey was born (1859, the same year Darwin published On the Origin of Species, which was, like the French Revolution and democracy in America, a major challenge to static visions of the universe). His death occurred a decade after the French civil unrest in 1848 and just before the division and destruction of the American Civil War that he had foreseen as a strong possibility. Furthermore, he had chronic health problems as did Emerson (his eyes) and James (depression), and he died of tuberculosis like Thoreau. He was also, like all four of these enormously creative, energetic, cosmopolitan Americans, both a thinker (in the moralist, prophetic tradition of essayists from Montaigne and Pascal to Montesquieu and Rousseau) and a practical man of action who extolled what Emerson called "the infinitude of the private man" and believed in the possibility of liberty and justice for all.

While reading The Mind on Fire, Robert D. Richardson's wonderful biography of Emerson, during a university strike in 1995, I learned that Emerson had actually met Tocqueville during his second trip to Europe in May 1848 - one in a long line of revolutionary "French springs." I was also struck by the fact that they had both made bold, soul-searching trips to the country and continent of the other practically at the same time and for roughly the same length of time-nine months. The time it takes to give birth, so to speak, to new ideas, projects, and prophecies, and both of them clearly did.

Tocqueville arrived in America on May 9, 1831, and returned to France on February 20, 1832. Emerson first sailed for Europe on December 25, 1832, and arrived back in Boston on October 9, 1833. Therefore Tocqueville could have run into Emerson in Boston, in Concord, or somewhere else in America, but I have read no account that 
says he did. The man known to his family and friends as Waldo had not yet become Emerson, and there is no reason that Tocqueville and his traveling companion Gustave de Beaumont, who were officially in America as government emissaries doing research on the American penitentiary system, would have sought him out.

But by 1848 it was fitting that they should meet in Paris since by then both Emerson and Tocqueville were on their way to becoming the preeminent witnesses of the strengths and weaknesses of their respective countries, astute readers of the signs of the times, and disturbing oracles about what the future might hold. And of course 1848 was not just any year, but the hottest revolutionary period since 1789 , which would later be a nostalgic source of inspiration if not exactly the blueprint for later revolutionary moments in France and elsewhere: 1871 (the Paris Commune), the 1930s (with the rise of Nazism and Fascism, the time of the Spanish Civil War, and the era of Franklin D. Roosevelt in the U.S. and Léon Blum and the Front Populaire in France), and of course 1968 (Prague, Paris, Berkeley) and 1989 (the Berlin Wall, Tiananmen Square, the World Wide Web). The revolutionary upheavals and democratic aspirations that spread throughout the Middle East in 2011, the so-called Arab Spring, also elicited comparisons in the French press with the printemps des peuples of $1848 .^{5}$

However, while they defended liberty and justice, Tocqueville and Emerson were both tradition-minded reformists who were largely opposed to l'esprit révolutionnaire and to socialism. Emerson famously refused to join the utopian communities that seduced many of his friends and acquaintances, ${ }^{6}$ while Tocqueville considered the poet Lamartine's revolutionary zeal foolish; ${ }^{7}$ and Louis Auguste Blanqui's advocacy of a "dictatorship of the proletariat" in a speech in May 1848, which Emerson witnessed firsthand, shocked them both as terrifying fanaticism. ${ }^{8}$ At the time they met, Tocqueville was serving on a constitution drafting committee to try to insert some checks and balances (such as a bicameral legislature) into the precarious French democratic experiment, though he confesses in his Souvenirs that the results fell far short of the work of Madison, Hamilton, and Jay and did not manage to forestall the eventual breakdown of order during the "days of June" or moderate the eventual pendulum swing back to total law and order during the Second Empire 
of Napoleon III. ${ }^{9}$ We will return in a later chapter to Emerson and Tocqueville's shared aversion to socialism, their sympathy for the individual, and their fundamental belief in man's essential freedom. My point here is simply to underline that it was a natural transition for me, after having completed my general introduction to Emerson for the French, to turn my attention to the second great witness of the American experiment in self-reliant popular sovereignty, Alexis de Tocqueville. ${ }^{10}$

The present volume is the product of my thinking about Tocqueville and democracy since his bicentenary year, 2005, when I began teaching a yearly seminar, on Tocqueville and democracy, to groups of French students as well as to visiting foreign students from all over the world who choose to study French for one year in Lyon while also taking law, business, or humanities courses all taught in English. These classes have been enjoyable and instructive. Enrollment has been consistently high, and students seem genuinely engaged by the material though very few have ever read Tocqueville before and many have never even heard of him. My French students seem glad to fill a hole in their culture générale and enjoy comparing their contemporary impressions of democracy with those of a nineteenth-century "Erasmus student" from Normandy doing field research. ${ }^{11}$ My Asian students, though mostly born after 1989 now, are generally curious about the word democracy in the title of the book to be studied and particularly interested in Tocqueville's assessment of democracy's strengths and weaknesses. For an American professor like me trained in the Socratic method and often stymied by tight-lipped French and Asian students who usually prefer to listen and take notes in class, it's a relief to find that the material practically teaches itself since most of the students are willing to break their habitual silence and readily adopt Tocqueville's own comparative method, pointing out similarities or differences between the situation he describes and the political situation in their own country. So I am convinced that students find Tocqueville and his writings compelling and relevant. Indeed, I would like to report signs of a general groundswell of enthusiasm for Tocqueville and democracy beyond the classroom as well, because I have sympathy for both, but in fact there is little evidence of either.

Reports of a revival or rediscovery of Tocqueville since 1989 or 2005 are in my view exaggerated. I've spent hundreds of hours commuting to 
work by train over the past twenty years, and I've yet to see anyone reading Tocqueville. No one who discovers I'm working on Tocqueville has ever said to me, "Ah, j'adore cet auteur!" That Tocqueville is frequently mentioned in books or articles, or cited with a line or two pulled out of context, everywhere from Vanity Fair to the New York Times to the most in-depth scholarly journals, is scant proof that his work is actually read, understood, or respected. ${ }^{12}$ The fact is Tocqueville remains largely inaudible ${ }^{13}$ to older French readers, who are likely to prefer his contemporary Balzac (1799-1850) if they're still willing to read a dead author, and shunned by younger French people, who, despite France's traditional love of history, increasingly ignore anything that is not about themselves or that happened before they were born.

The same could be said about Americans, even more so perhaps, despite Tocqueville's induction into the Library of America series with the Arthur Goldhammer translation of Democracy in America (2004) the third translation to appear in quick succession after Mansfield and Winthrop (2000) and Bevan (2003) and just before the 2007 Norton Critical Edition edited by Isaac Kramnick that opted to recycle the original English translation from 1841 by Henry Reeve. ${ }^{14}$ So there is undeniable classroom enthusiasm about Tocqueville. I've seen it, and publishers have clearly been willing to compete with each other for a share of this no doubt small but I guess reasonably secure market. But in the larger scheme of things, Tocqueville's Democracy in America stands as further proof of Mark Twain's definition of a classic-something everybody wants to have read but nobody wants to read.

Am I then just preaching to the converted, and to a rather small congregation at that? No, that is not my purpose, nor, as I see it, is there much incentive to address myself exclusively to Tocqueville scholars, since a perusal of the commentaries published on Tocqueville in the Internet age shows that many are manifestly uninterested in taking into account what their peers have to say on the subject. As I've said, they seem often not to have read each other's work, and what's more some of the best Tocqueville studies of the past dozen years have not been translated out of their original language. I would be delighted to be read by Tocqueville specialists as well as by curious nonspecialists, and they are both a part of my intended audience. But like Thoreau's Walden (1854), this study 
is also addressed to "poor students," especially students poor in imagination and short of time- not that I think their lack of imagination, narcissism, materialism, and now-focus are all their fault. One could even say, after reading Tocqueville, that focusing on short-term gains is perfectly normal and to be expected in democratic times. Tocqueville teaches one to understand how democracy raises decent but nearsighted men and women that I will refer to as "demolanders."15

In short, I believe Democracy in America is a marvelous resource, and knowing about Tocqueville and democracy is good for students and all voting-age citizens, just as I think it's good to know how irony works, to know the difference between classicism and romanticism, and to commit to memory a few poems (and write a few of one's own). I have the genuine conviction from the lively thinking I see deployed in term papers and final exams that students are truly grateful to have discovered Tocqueville, grateful to make some connections and feel less "clueless in academe," 16 less "academically adrift." ${ }^{17}$ Emerson said the American scholar ought "to cheer, to raise, and to guide men by showing them facts amidst appearances." ${ }^{18}$ That is what Tocqueville did-though ultimately, like E. M. Forster, he was not prepared to give more than two cheers for democracy-and that is what I intend to do. ${ }^{19}$ But why this book now? It is not for material gain. I already have tenure and make a decent salary by French standards. I am motivated by an immaterial, I would even say spiritual necessity to step up and share my thoughts and feelings on this subject-Tocqueville and democracy in the Internet age-during a window of time in human history that sees men and women yearning for a new "sustainable" direction-for themselves, their loved ones, and the planet-and half-aware that if careful attention and application to this common search do not come soon, grave consequences for mankind and indeed all life forms are likely to ensue. I see myself, therefore, as a witness, and this book is my testimony and my contribution to that search.

In this pursuit Tocqueville, per se, is not of capital importance, though I persist in my belief that he is a valuable resource for discussing democracy and actual democracies and mapping out their future. That is what matters most. Editorially, Tocqueville studies is in a relative calm or holding pattern. The flurry of publications that came out around the bicentenary of the author's birth is over, and the bicentenary of his masterpiece 
Democracy in America is still a ways off in 2035. Tocqueville's writings received a burst of media attention at the end of the Cold War and the beginning of the Internet age (1989-1991), and again around the time of $9 / 11$, and yet again around the 2005 bicentenary. ${ }^{20}$ But that attention has mostly subsided now, which makes a lucid assessment of that earlier set of reflections more possible. And perhaps more valuable, because what has become increasingly popular and visible in the post-Cold War Internet age is debating the viability, suitability, and sustainability of democracy in the world today, a debate that goes on with or without Tocqueville's help, depending on the participants, as part of the larger question about "the wealth of nations" and "why nations fail." ${ }^{21}$ I will be making my contribution to that ongoing conversation in the second part of this book after a review of Tocqueville's strengths and weaknesses and those of some of the most noteworthy commentators of the past twelve years.

A list of world events since 1989 that have been the focus of discussions about democracy would include the following: the creation of the World Wide Web by Tim Berners-Lee and others, the fall of the Berlin Wall, the reunification of Germany, the collapse of the Soviet Union and the political and economic changes within Russia and the former Soviet satellite countries in Eastern Europe, the Masstricht Treaty establishing the European Union (1992), the Tiananmen Square protests in China, China's economic reforms under Deng Xiaoping, the creation of Google and the entry of Google into China, the disputed U.S. presidential election in 2000, "9/11" and other terrorist attacks (Madrid, Bali, London, Mumbai), the war in Afghanistan and the second war in Iraq, the American military's use of "extraordinary rendition" and torture during its "war on terror," the establishment of a five-year term and term limits (two) for French presidents, the "reign" of Nicolas Sarkozy and Angela Merkel (referred to briefly as "Merkozy"), the election of U.S. president Barack Obama (2008, 2012), the French "non" to the European Constitution (2005), the Lisbon Treaty establishing further European rules on immigration and the Schengen area of free movement within the European Union (2007), the global availability of Facebook accounts (2006) and Facebook's IPO (2012), the financial crisis of 2008 and the "bailouts," the "Great Recession" and "austerity" policies that followed, mass demonstrations of "indignant" citizens in several Mediterranean 
countries (2011), and the democratic movements in several Middle Eastern countries starting with Tunisia (December 2010) known as the "Arab Spring."

Other events of more local concern, but that of course become world events in this Internet age of instant global communication, would include the completion of France's switchover from Minitel to the Internet (2012); the U.S. Supreme Court's decision to permit essentially unlimited political campaign spending by corporations and unions (Citizens United vs. Federal Election Commission, 2010); the Oslo massacre (2011); the bombing of Libya (2011); the government suppression of civilian protests in Yemen, Syria, and Bahrain; the English riots against state spending cuts (2011); the heating up of the Scottish independence movement (2012); the Italian referendums against Berlusconi (2011) and his eventual ouster; the return amid protests and charges of corruption of Vladimir Putin as Russia's president (2012); and the presidential election victory of French Socialist party candidate François Hollande (2012), to name just a few.

A more diffuse set of incremental large-scale changes that have also entered into debates about world democracy— "too big to fail" or "too small to succeed"? - include the spread of automation, personal computers, broadband access, cell phones, and smart phones. There is also the impact of so-called social media that has intensified and diversified the practices of e-mail, blogging, texting, instant-messaging, "Googling," "Wikiing," and "Tweeting." Besides these technological changes in the way we live now that some might consider a new "passive revolution" (Gramsci) for good or evil, there have been widespread social changes such as the corporate, business-minded (and sometimes mafia-minded) takeover of the public sphere, the incremental privatization of many public government services (in health care, education, transportation, etc.), and the growth of individual retirement accounts and online trading, as well as the emergence of various countercurrents including the "slow food" and "real food" movements, the "antiglobalization," "altermondialisation," and "global justice" movements, the "green" movements, and loosely organized opposition groups such as the Tea Party in the U.S. or the "Indignant" demonstrators in Spain, France, and other European countries and the "Occupy" movements inspired by the protests in 
Cairo's Tahrir Square since the 2011 winter of discontent with the Moubarak regime.

Finally, alongside these specific events and widespread changes and trends, one must consider the global pressures that have spurred both democratically organized associations of ordinary citizens and cohorts of government or corporate-sponsored experts and officials who exhibit a marked skepticism or even contempt for democracy and democratically elaborated solutions to current world problems. ${ }^{22}$ First among these pressures is overpopulation, a subject succinctly treated by Aldous Huxley in 1958 in his Brave New World Revisited and more expansively in Paul Erlich's bestseller from 1968, The Population Bomb, but curiously absent from news headlines today despite the efforts of groups such as World Population Awareness (www.overpopulation.org) and readily available statistics that show the world population has nearly doubled since 1968, from 3.5 billion to 7 billion in 2011, and will reach 9 billion in 2041 . Other world pressures that are provoked and worsened by overpopulation (though this correlation is routinely ignored by the media) and in turn aggravate tensions between democracy believers and democracy skeptics include xenophobia and racism; mass migrations and homesickness, pollution and waste disposal; global warming and climate change, and shortages of water, food, energy, arable land, hospitable living environments, and good jobs. Predating and underlying these contemporary pressures on all societies and governments is a long-standing fundamental disagreement between democracy believers and skeptics about the existence of what New Yorker magazine business columnist James Surowiecki calls "the wisdom of crowds." 23

Tocqueville usually had two things in mind when he talked about the birth and growth of democracy. The first was expanding equality of social conditions, by which he meant more literate people, more landowners, and more people living in basically similar ways when it comes to their shared memories, customs and habits, and aspirations. The second was a system of government: popular sovereignty - "government of the people, by the people, for the people," as Abraham Lincoln memorably put it in his Gettysburg Address (1863). These two notions of democracy are the main focus of the first volume of Democracy in America. In the second volume that Tocqueville published five years later, he develops a third 
sense that is democracy as a way of life, and even a religious faith though nowhere does he explicitly call democracy a religion. For Tocqueville, democracy clearly gives rise to a new species of homo sapiens, the demolander, who has different core beliefs and habits, or "mores," than his ancestors.

The least controversial sense of the term democracy is when it is used as a synonym for expanded access. When the French, for example, speak of something being démocratisé, they usually mean that access to that product, service, or institution has increased to the point of becoming ordinary, banal, available to nearly everyone (often because of a drop in price or some change in the rules that regulate access). If early symbols of French démocratisation were the beret, the baguette, and the camembert, today they are postsecondary education, a cell phone, and vacation time at the seaside or abroad.

The less frequently heard meaning of démocratisation (no doubt because it occurs less often) is the expansion of the democratic character of a political regime, i.e., an increase of decision-making power in the hands of ordinary people, whether elected or appointed. It's one thing to allow, say, student or parent representatives to attend school council meetings and sit around the same table with the principal, the faculty, and municipal school board members; it's another thing to let them vote. Calls in France for "démocratie réelle" and more "démocratie participative," such as one heard during the unsuccessful presidential campaign of Socialist candidate Ségolène Royal in 2007, tellingly underscore the long-standing preference in the République Française (and many other so-called democracies) for low levels of political involvement by ordinary people-in effect, democracy without democracy. Your presence may be tolerated in the room, or within the territory, but you will have little or no power, no say when it comes to public policy-making, no real participation. The history of France's Fifth Republic has been one of liberal, though sometimes backhanded démocratisation in the first social sense (let the masses have access to cheap-i.e., inexpensive and shoddyhousing and higher education) and conservative containment of démocratisation in the political sense. Therefore don't allow trial by jury, don't let tax-paying foreigners vote, and do allow politicians to hold more than one elective office at the same time with no term limits. But France's 
ruling class is hardly the only political elite that is annoyed by voting and its ground rules ( 1 person $=1$ vote, all votes are to be counted, majority rule, etc.) and quietly skeptical or openly hostile to allowing important decisions to be decided by popular vote. Democracy skeptics are everywhere. Look around.

One of the reasons there are so many, as James Surowiecki demonstrates, has to do with the success of the unproven claim that while a person may be smart, people are stupid. ${ }^{24}$ One might call this a class prejudice that the more powerful and highly educated minority have against the majority of ordinary people, often pejoratively lumped together as "the masses." For the elite, who quite naturally consider their rule and their rules to be the best (being themselves the aristoi, the aristocracy), voting and hence democracy equals "mob rule," and anyone who says otherwise is decried as a "populist." "Mob rule" has to be the most enduring slur against democracy since the "storming" of the Bastille by a "mob" in 1789, and a charge that democracy believers feel they have to constantly fend off. ${ }^{26}$ What Surowiecki goes on to show is that in this face-off between snobs and mobs, diverse groups of ordinary people turn out to be better decision makers than elites so long as certain preconditions are in place, namely diversity, independence, decentralization, and a well-thought-out aggregating mechanism for collecting and tabulating the results of individual "votes" (whether for a candidate, restaurant, or football team). It's a fascinating and upbeat study if one is a democracy believer, as Surowiecki would seem to be. His concluding chapter, "Democracy: Dreams of the Common Good," strikes a hopeful note in the key of Tocqueville one could say.

[Democracy] is not a way of solving cognition problems or a mechanism for revealing the public interest. But it is a way of dealing with (if not solving once and for all) the most fundamental problems of cooperation and coordination. How do we live together? How can living together work out to our mutual benefit? Democracy helps people answer those questions because the democratic experience is an experience of not getting everything you want. It's an experience of seeing your opponent win and get what you hoped to have, and of accepting it, because you believe that they will not destroy the things you 
value and because you know you will have another chance to get what you want. In that sense, a healthy democracy inculcates the virtues of compromise-and change. The decisions that democracies make may not determine the wisdom of the crowd. The decision to make them democratically does. (271, my emphasis).

Surowiecki's conclusion gets to the heart of the most complex and interesting sense of democracy-democracy as a way of life and a belief system-that Tocqueville spent most of his time in Volume Two of Democracy in America presenting and explaining to his largely skeptical French readership. In that second companion volume Tocqueville devotes many chapters to the new kinds of relationships that develop between demolanders. Living democratically, as Surowiecki underlines, involves a belief in certain shared core values between oneself and one's fellow man (e.g., honesty is the best policy, cheating and dehumanization are wrong, being a gracious winner and a good loser is right) despite individual differences of taste or direction, as well as a commitment to the open-ended, ongoing debate (because circumstances are constantly changing) over the virtues and defects of specific policies and preferences. In a democracy "tomorrow is another day," as Margaret Mitchell had Scarlett say in 1936 about life in 1865. Positions and perspectives may (can / are allowed to) change. The eccentric Spartan Yankee Thoreau knew this when he concluded Walden with the stirring words, "There is more day to dawn. The sun is but a morning star."

Tocqueville says something similar in the concluding paragraphs of Democracy in America when he compares his own partial view of the world to that of the "Almighty Eternal Being, whose eye necessarily encompasses all things and sees the entire human race and each man distinctly yet simultaneously." In the following two paragraphs Tocqueville affirms a natural religion whose core tenet-similar to Thoreau's credo and to Emerson's "transparent eyeball" declaration from Nature (1836) - is to respect the equal dignity of all life. He confesses his reflex to condemn what, from his perspective, may strike him as decadent or painful, and he affirms his effort to adopt the universal perspective that democracy presupposes and reaffirms at every turn. 
It is natural to believe that what is most satisfying to the eye of man's creator and keeper is not the singular prosperity of a few but the greater well-being of all: what seems decadence to me is therefore progress in his eyes; what pains me pleases him. Equality is less lofty, perhaps, but more just, and its justice is the source of its grandeur and beauty.

I am doing my best to enter into this point of view, which is that of the Lord, and trying to consider and judge human affairs from this perspective. (DA II, 401, G833)

Tocqueville's God, therefore, is a democrat, not a Platonist or republican, and Tocqueville, by the work he seems to have done on himself in overcoming certain ingrained aristocratic tendencies while retaining others, invites us on a similar journey of self renewal via questioning, rethinking, and ultimately a leap of faith and trust. ${ }^{27}$

In the following pages we shall see that democracy, like a loving marriage or close friendship, can be not only a way of life-a religion or reliance on another person or people-but also a kind of therapy, a repairing of the connection with our lost self, with others, especially a "significant other," and with the larger world that we all need and desire. I have become newly persuaded of this universal desire for connection from reading, of all things, a self-help "guide for couples" by Harville Hendrix and his wife Helen Lakelly Hunt, Getting the Love You Want (2008).

Above all else, we seek connection-with parts of ourselves that we have repressed, with other people, and with the larger universe. We cannot experience life in its fullness unless we have an intimate relationship with another human being and, beyond that, a feeling of connection with the world around us. (xvii-xix)

I can imagine Tocqueville going along with this affirmation since getting the love you want is not all that different from a cooperative approach to getting the governance you want. Because of its valorization of horizontal, cooperative relations among co-equals (as opposed to vertical relations between superiors and subordinates-however necessary those may also be in certain circumstances) democracy, more than any other form of government or way of life, favors feelings of ordinary dignity and 
connection. In its most nontrivial sense, but also that which is most controversial and controversy creating, democracy, like the new language codes that are the currency of our Internet age, is an open-ended, everchanging system that advances or declines according to cause and effect relationships that are difficult if not impossible to direct or determine at one go or from a single position-a fact that some may find aggravating, but to democrats who recognize both the infinity and the fallibility of the private man, it is the saving grace that has so far kept us from making too many unrepairable mistakes and allowed us to continue to build new connections and honor some old ones.

That democracy makes repairable mistakes is one of the regime's "real advantages" that has received less attention than others, ${ }^{28}$ but it may be one of the most important, especially at the present time. Democracy may or may not be too big to fail, especially in the post-Cold War era, where it lives on precariously without its oppositional bad conscience, Communism, that acted as a useful prod to the "Free World" to live up to its name. But it has become, along with the notion of dignity that it both presupposes and fosters, the name for a desire for connection and wholeness that millions of people, billions even, have pinned their hopes on.

\section{$\phi$}

Part One of this study begins with a presentation of the main themes of Democracy in America and then offers a coordinated critical assessment of eight recent Tocqueville \& democracy studies by leading American and French specialists: Agnès Antoine, Leo Damrosch, Jon Elster, JeanMichel Heimonet, Claire Le Strat and Willy Pelletier, Paul A. Rahe, Emmanuel Todd, and Sheldon S. Wolin. The distinctive view that follows from these commentaries of commentators is that Cold War-era concentration on part 4 of Volume Two of Democracy in America with spooky scenarios of "soft despotism" is no longer as pertinent in the Internet age when so many, though not all, have already made their peace with "managed democracy" and not only do not find it scary but positively welcome it (in Russia, the U.S., and elsewhere). While not discounting the enduring importance of DA II, 4, I will argue that the center of gravity and reader's attention should shift in today's world to the earlier Parts Two and especially Three of Volume Two where Tocqueville can be helpful 
in getting us to think better about both personal and public relationships that either extend or harm "the spirit of democracy."

Part Two surveys democracy today as measured by various "democratic audits" 30 that have been conducted by groups (such as Democratic Audit) and by individuals who are each in various ways following in Tocqueville's footsteps as singular witnesses of democratic practices and institutions over a particular territory. Each auditor comments on democracy's strengths, weaknesses, and sources of resistance, but without necessarily coordinating their efforts with those of other auditors past or present-a gap I try to fill. In my own audit, a rough measurement of advances versus declines of democratic practice in the United States and France receives special attention. This survey is then set against the background or "distant mirror" offered by several British witnesses (Charlie Chaplin, E. M. Forster, Aldous Huxley, and George Orwell) who were each deeply affected by the political and social turmoil of the 1930s, a time that bears many resemblances to our own. Key elements from canonical works by these artists are used to highlight points made by Tocqueville and latter-day democracy auditors discussed in previous chapters. Finally, as a sort of bridge between then and now, I comment on some essays by the late British-American historian Tony Judt (19482010), who was in some ways more an anachronistic throwback to 1930 s modernism than he was representative of his own postmodern time.

Part Three brings the focus back to the contemporary situation of democracy and dictatorship today with summaries of important recent news items from France, the United States, Russia, and of course the Middle East with its "Arab Spring" and widespread civil unrest. After this short survey of democracy-related events that took place between December 2010 and December 2011, a second chapter discusses the emergence of dignity as a human right and then makes use of Tocqueville's isolated but important evocations of dignity to ask whether contemporary dignity-talk is a sign of democracy's triumph or defeat. Or if it is a sign, or perhaps even a battleground, of democracy's ongoing struggle with forces that would seek to contain it with a variety of management techniques ranging from the ruthless and brutal to softer, gentler ones (such as mass marketing of electronic devices) that insecure, overly preoccupied citizens might be all too willing to go along with. Part Three 
concludes with an inventory of Tocqueville's policy recommendations "to create or secure the independence and dignity" of men and women in times of relatively high equality of social condition, which, alas, as he noted, are also the conditions most favorable for establishing an absolute and despotic government. Based on his experience and his reading of other theorists such as James Madison, Tocqueville affirms that the many real advantages of democratic government (respect for rights and the rule of law, enhancement of the creativity and well-being of the greatest number, building confidence and self-esteem) cannot be sustained over the long term unless auxiliary precautions are put in place that can protect a democratic regime against both outside attacks and its own self-destructive tendencies.

The Conclusion offers a list of ten more specific policy recommendations articulated with mostly North America and Europe in mind but of general interest to any country, region, or other social entity seeking to build or block democracy.

In the Appendix the reader will find the answers to twenty factual questions about Democracy in America. It is a stand-alone component of the book (designed to be read before or after reading Tocqueville), as are all the chapters, which can be read profitably each on its own and in any order the reader chooses. This is a deliberate concession to the nonlinear, click-here-or-there habits of more and more readers in the Internet age. At the same time, the book is emphatically not a compilation of essays. There is coherence and a definite progression between all the component parts even as the "plot" moves between the 1830s, the 1930s, and today. Like Tocqueville's own prose, the book tries to balance seriousness and a plain style that is accessible to ordinary readers. Like democracy, I am trying to look out for the well-being of the greatest number and convey a sense that, although I am the author, "we're in this together."

If, as Sheldon Wolin and others have argued, ${ }^{31}$ democracy is incompatible with our divisive contemporary form of CEO-, shareholder-, financial-services-driven capitalism with its top-down corporate organization and ardent worship of profits, capital gains, and endless "growth," then it's up to people to find a way to treat and heal the individuals and communities mangled by capitalism's destructive side and to place their 
society on a surer path toward overcoming factionalism and building more sustainable relationships and associations. ${ }^{32}$

The bottom line, as people living in democratic times love to say, is that Tocqueville is a useful guide when it comes to this (re)building project, and his usefulness, I claim, has not diminished but increased in the Internet age with its ramped up versions of the market and communications revolutions that the 1830s America Tocqueville witnessed was experiencing in its early stages.

I invite you to read on and see if you agree.

\section{Notes}

1. See John Dunn, Democracy: A History (New York: Atlantic Monthly Press, 2006), Chapter One. As late as 1767, Adam Ferguson in his Essay on the History of Civil Society uses the term democratical in a rather condescending, disbelieving way as though it were a far-fetched and certainly temporary thought experiment-more theoretical than actually practical.

2. See Harvey C. Mansfield and Delba Winthrop's “Editor's Introduction” to their translation of Democracy in America (Chicago: University of Chicago Press, 2000), xvii. See also Robert N. Bellah with Richard Madsen, William M. Sullivan, Ann Swidler, and Steven M. Tipton, Habits of the Heart: Individualism and Commitment in American Life, 3rd edition (Berkeley: University of California Press, 2007 [1985]), 298: “Tocqueville's sense of American society as a whole (...) has never been equaled."

3. See David McCullough, "Vive la Similarité," New York Times, July 13, 2011.

4. The first commercial dialup ISP, The World, began in 1989, the year when CERN opened its first external TCP/IP connections. A CERN collaborator, Tim Berners-Lee, played a leading role in the development of the global connectivity technology that eventually became known to us all by the letters www. On November 9, 1989, the Berlin Wall was breached by thousands of East Berliners, marking the beginning of the end of the Communist era in Eastern Europe and in the Soviet Union, which was dissolved in 1991.

5. See the editorial by Philippe Tureau-Dangin in Courrier International, no. 1058, February 10, 2011, <http://www.courrierinternational.com/ magazine/2011/1058-le-printemps-arabe-vu-par-la-presse-arabe>.

6. Robert D. Richardson, The Mind on Fire (Berkeley: University of California Press, 1995), 337-344. 
7. See Alexis de Tocqueville, Souvenirs, preface by Claude Lefort (Paris: Gallimard/Folio, 1964, 1999), 151-153.

8. Richardson, 454. Tocqueville shared the view that Blanqui was truly mad and adds, "I have always thought that in revolutions, especially democratic revolutions, the mad, and not just those who are called by that name metaphorically, but the truly mad played a very significant political role," Souvenirs, 165, my translation.

9. Souvenirs, 223-231. See Richardson's Chapter Seventy-seven, "Chartism and Revolution," 451-456.

10. C. Jon Delogu, Ralph Waldo Emerson: Une Introduction (Rennes: Les Perséides, 2006).

11. Started in 1987, the "Erasmus Program" became the European equivalent of North America's “junior year abroad”-encouraging student mobility and intercultural exchange.

12. See Joseph Stiglitz, "Of the 1\%, by the 1\%, for the 1\%," Vanity Fair, May 2011. Tocqueville was mentioned as an authority in two of four letters to the editor published together under the title "Closing the Gap Between Rich and Poor," New York Times, March 9, 2012.

13. Inaudible, perhaps, but not invisible on the Web. See, for example, the documents gathered at <http://xroads.virginia.edu/ HYPER/DETOC/ home.html $>$ by the University of Virginia and at this French website: <http://www.tocqueville.culture.fr/fr/>. See also the Université du Québec à Chicoutimi's "Les classiques des sciences sociales” collection here: <http:// classiques.uqac.ca/classiques/De_tocqueville_alexis/de_tocqueville.html $>$. Digital versions of Democracy in America and De la démocratie en Amérique are helpful because they allow one to search efficiently for key passages that are frequently unsourced by commentators who mention or quote from Tocqueville and also because Tocqueville often writes about a given topic in several different chapters that are easy to confuse and misplace.

14. In a characteristically self-assured, witty, and often perceptive New Yorker magazine book review from 2001, Adam Gopnik predicts the Mansfield and Winthrop translation "will be the English translation of Tocqueville for a long time." See "The Habit of Democracy: Alexis de Tocqueville and the Pleasure of Citizenship,” New Yorker, October 15, 2001, 212. Sales information at Amazon.com in August 2011 places the four editions in this rank: Bevan (4,014), Mansfield and Winthrop (7,731), Goldhammer $(24,392)$, Reeve $(309,613)$. There is also the 1966 George Lawrence translation still in print at Harper (2000), rank 124,319. To his credit, Gopnik's derisive opening paragraph does offer the most accurate translation of the title of Tocqueville's masterpiece: "De la Démocratie en Amérique" ("On Democracy in America"). This English title more accurately reflects 
the tentative, essay-like character of Tocqueville's project, which follows in the footsteps of his countrymen Montaigne, Pascal, and Montesquieu. The standard translation, Democracy in America, with its pretension of offering the definitive portrait, does not get this across and may instead have inadvertently fueled attacks against Tocqueville as yet one more arrogant French theorist.

15. This term conveniently designates those who live in a society that has for at least three generations been organized more or less democratically (i.e., with generally expanding equality of social conditions) whether or not they consciously believe in or adhere to democratic policies or parties. In other words, a Republican living in contemporary America would be, in my view, a demolander though not a Democrat. And all American Democrats are demolanders whether or not they actually believe in democracy or have even given it a thought. France's Fifth Republic could be considered either a very young demoland or an "aristoland" republic transitioning to demoland status, perhaps, since many French grandparents today, including a large number of France's elected officials, were born before its creation in 1958. For example, France's current president, François Hollande, was born in 1954. Nicolas Sarkozy was born in 1955 and Jacques Chirac in 1932. In other words, there are fewer demolanders in the world than democracies. The roughly fiftyyear-old American democracy that Tocqueville witnessed was already an old demoland since its people (at least white males) had experienced five generations of relative equality and vigorous local self-government before America became officially independent from the British monarchy in 1781.

16. Gerald Graff, Clueless in Academe: How Schooling Obscures the Life of the Mind (New Haven: Yale University Press, 2003).

17. Richard Arum and Josipa Roksa, Academically Adrift: Limited Learning on College Campuses (Chicago: University of Chicago Press, 2011).

18. “The American Scholar” (1837), in The Portable Emerson, ed. Carl Bode (New York: Penguin/Viking, 1946, 1981), 62.

19. We shall return to Forster and other British observers of democracy and the specter of totalitarianism in Part Two, Chapter Two.

20. See Isaac Kramnick's account of Tocqueville bicentenary enthusiasm in his Introduction to the Bevan translation (ix-xii) and to the Norton Critical Edition (ix-xvi).

21. See Adam Smith, The Wealth of Nations (1776). Empire anxiety and the rise and fall of nations has been a perennial topic of interest since the days of Adam Smith and Adam Ferguson. Other important early contributors were Gibbon, Montesquieu, Rousseau, and Tocqueville, to which have been added contemporary academic studies such as those by Paul Kennedy (The Rise and Fall of the Great Powers, 1987), Emmanuel Todd (After the Empire, 2003), and 
most recently Daron Acemoglu and James Robinson's Why Nations Fail: The Origins of Power, Prosperity, and Poverty (New York: Random House, 2012).

22. See David Runciman, “Can Democracy Cope?” Political Quarterly 82:4 (Oct.Dec. 2011): 536-545.

23. Surowiecki's highly readable study, The Wisdom of Crowds (New York: Random House/Anchor, 2004), is a good example of the "magpie" or "mashup" research typical of the Internet age. The Wikipedia entry on the book provides a useful summary. The magpie is typically an analyst/chronicler of the "crowdsourced" collective consciousness or Zeitgeist. Other successful magpie authors who skillfully blend entertainment and instruction include Steven D. Levitt and Stephen J. Dubner, Malcolm Gladwell, Richard Thaler and Cass Sunstein, Nassim Nicolas Taleb, and Jean M. Twenge and W. Keith Campbell. For a survey of this magpie trend see Michiko Kakutani's book review of Jaron Lanier's You Are Not a Gadget (New York: Random House/ Vintage, 2010), “Texts without Contexts,” New York Times, March 21, 2010. The present study deliberately adopts some magpie tendencies.

24. Surowiecki's Introduction provides a selection of "people are stupid" pronouncements beginning with Charles Mackay, author of Extraordinary Popular Delusions and the Madness of Crowds (1841) and continuing to Bernard Baruch, Thoreau, Nietzsche, Carlyle, and the French writer Gustave Le Bon, author of the "polemical classic" The Crowd: A Study of the Popular Mind (1895), xv-xvi.

25. See Pascal Mbongo, "Populisme et démocratie," Le Monde, November 5, 2010.

26. See, for example, the concluding paragraph of Diana Saco's award-winning study Cybering Democracy: Public Space and the Internet (Minneapolis: University of Minnesota Press, 2002), 211: “This is not a defense of so-called mob rule, but rather a condemnation of any 'elite stance' that, as William Gibson puts it, evinces a 'certain relaxed contempt for the flesh' $(1984,6)$." The charge of "mob rule" is always zeroing in on the questionable foundation of the "moral empire" of the majority as Tocqueville called it, namely the idea that "there is more enlightenment and wisdom in an assembly of many than in the mind of one" (DA I, 344, G284). "This doctrine strikes at the last refuge of man's pride," says Tocqueville, and "Hence the minority is reluctant to accept it and takes time to get used to it." Skepticism about the enlightenment of the majority is one of the main obstacles to getting democracy to stick in places where people have little practical experience with democratic institutions and attitudes.

27. On the idea of Democracy in America as intending above all to induce in the reader a continuous critical self-examination, see Tocqueville's letter to Corcelle, September 17, 1853, in Oeuvres completes, XV, 81. This important letter is quoted and discussed by Jean-Michel Heimonet, Tocqueville et 
le devenir de la démocratie: La perversion de l'idéal (Paris: L'Harmattan, 1999), 376-377.

28. See DA I, 2, ch. 5, 318, G258: “The great privilege of the Americans is not just to be wiser than other peoples, but to have the faculty of making repairable mistakes" (my translation).

29. See Larry Jay Diamond, The Spirit of Democracy: The Struggle to Build Free Societies throughout the World (New York: St. Martins, 2008).

30. The term democratic audit was popularized by Kevin Boyle and his collaborators during the early Blair years that resulted in Auditing Democracy in Britain: The Democratic Audit of the United Kingdom-Democratic Audit Paper (1993). Kevin Boyle and David Beetham also co-authored for UNESCO the instruction manual Introducing Democracy: 80 Questions and Answers (Cambridge: Polity/UNESCO, 1995).

31. Sheldon S. Wolin, Democracy Incorporated-Managed Democracy and the Specter of Inverted Totalitarianism (Princeton: Princeton University Press, 2008). See also William Deresiewicz, "Capitalists and Other Psychopaths," New York Times, May 13, 2012: "Capitalist values are also antithetical to democratic ones. Like Christian ethics, the principles of republican government require us to consider the interests of others. Capitalism, which entails the single-minded pursuit of profit, would have us believe that it's every man for himself."

32. On "mangled or stupefied" lives, see Sheldon S. Wolin's subsection XI, "Capital and Democracy," in the concluding Chapter Seventeen, "Postmodern Democracy: Virtual or Fugitive?” of Politics and Vision: Continuity and Innovation in Western Political Thought, 2nd edition (Princeton: Princeton University Press, 2004), 596-597. See also the diagnosis and prescriptions offered by former Republican U.S. congressman Mickey Edwards, The Parties versus the People: How to Turn Republicans and Democrats into Americans (New Haven: Yale University Press, 2012). For another diagnosis and prescription that takes inspiration from William Morris and John Ruskin, but not (directly) from Tocqueville, see Bill Ivey, Hand-Making America: A Back-to-Basics Pathway to a Revitalized American Democracy (Berkeley: Counterpoint, 2012). 

I

Tocqueville 



\section{Chapter 1}

\section{Reading Democracy in America}

Tocqueville's masterpiece is Democracy in America, published in two volumes, five years apart, in 1835 and 1840 . He also wrote two other notable books: the political memoir entitled Souvenirs, written in 1850-1851 shortly after he had left politics but only published posthumously in 1893, and The Old Regime and the Revolution (1856). ${ }^{33}$ Although they also display Tocqueville's illuminating, against-the-grain thinking, some readers find these two works less satisfying than Democracy in America, which is the product of a more restless and hopeful young mind. Souvenirs has all the daring but also the flaws of many historical memoirs-one enjoys being in the company of a brilliant witness of the revolution of 1848, but one wonders to what degree the accounts he gives are true and truly valuable. ${ }^{34}$ This lively piece of "life writing" is both highly readable and troubling since, as Paul de Man famously observed, "Autobiography veils a defacement of the mind of which it is itself the cause." ${ }^{35}$ For somewhat similar reasons, to which must be added the facts of advancing age, illness, and disillusion, The Old Regime and the Revolution is an uncompleted study that a reader may find provocatively stimulating or annoying by turns. Besides these two works, Tocqueville wrote many other shorter pieces: government reports, travel essays, academic and political speeches, and countless letters. The still unfinished modern edition of his complete works (begun in 1951) will contain somewhere between thirty and forty volumes; an earlier Oeuvres complètes published after Tocqueville's death in 1861-1866 under the supervision of his travel partner and friend Gustave de Beaumont takes up nine volumes; and France's prestigious Pléiade collection presents a generous selection of Tocqueville's major works, travel writings, essays, and speeches in three hefty volumes. Fair or unfair, however, it is on Democracy in America that 
Tocqueville's reputation as a writer, theorist, historian, political scientist, and social scientist rests, and it is this work that will be the focus of our attention.

The following commentary is the product of several years of teaching Tocqueville to French and foreign undergraduates in France. I am not saying this is "all ye need to know," nor am I offering this commentary as a substitute for reading Democracy in America itself. This is why I have keyed my remarks to page numbers in the easily available two-volume paperback Garnier-Flammarion edition from 1981 and pair them with page numbers from the Goldhammer translation, which, being the most recent, has the best chance of having profited from observing and weighing the strengths and weaknesses of all earlier translations.

De la Démocratie en Amérique is about nine hundred pages long, while Goldhammer's Democracy in America is about eight hundred pages-French always shrinks a bit in the dryer of an English translation. Whatever edition one reads, however, it definitely qualifies as a big book; and yet if you read thirty pages per day, in about a month you're there, which makes it entirely manageable as an assigned text in a semester course or as summer or weekend reading.

The first volume is divided into two parts of eight and ten efficiently organized chapters plus a Conclusion. The second is divided into four parts consisting of twenty-one, twenty, twenty-six, and eight chapters that vary in length and whose subjects often overlap each other. The first volume would be about the same length as the second (roughly four hundred pages) were it not for the hundred-page final Chapter Ten of Volume One, Part Two, "Some Considerations Concerning the Present State and Probable Future of the Three Races that Inhabit the Territory of the United States." This last chapter is a supplement that Tocqueville might have considered publishing separately, for example, as a long introduction or review essay of the novel his friend Beaumont wrote after they returned from America, Marie, or Slavery in the United States-a portrait of American mores (Marie ou l'Esclavage aux États-Unis, tableau de mours américains, 1835). But in a way it's fitting for us that this chapter appear where it does, because it functions as a pivot between the major concern of Volume One, which is the history of Americans and their democratic institutions, and what one gets in Volume Two, which is Tocqueville's 
nonfictional "portrait of American mores" and his commentary of how those mores manifest themselves in daily American life. Mores, which rhymes with forays not doors, is the best translation of the French term mours that Tocqueville probably got used to from reading Montesquieu, and it means the "folkways of central importance accepted without question and embodying the fundamental moral views of a group." ${ }^{36}$ So this one-hundred page final chapter on American mours, filled with perceptively drawn "considerations" of different American types and their relations with each other, can be viewed as both a supplement to Beaumont's novel and as a spur that may have incited Tocqueville to come back to the matter and publish a longer, more detailed, and critical portrait of American mores five years later.

If in Volume One Tocqueville seems mostly content to play the disinterested scholar and present his observations and considerations with only the occasional critical aside or probing address to the reader via questions and the rare apostrophe to "you," in Volume Two he is definitely willing and able to do some side-taking. He argues in favor of the positions he wants to defend and criticizes views and behavior that he considers for different reasons to be wrong. This shift from a more dispassionate to a more impassioned Tocqueville can be observed in the two Introductions that are included in the French GF edition as well as in the Preface to Volume Two. ${ }^{37}$ All three of these short, argument-driven prefatory declarations convey Tocqueville's core convictions; namely that expanding equality of social conditions is a "providential fact" that marks the advent of democracy and the end of traditional aristocracy; that France is stuck between two modes of thinking, feeling, and behavingaristocratically and democratically-and needs to get unstuck; and that American democracy, though flawed and impossible to imitate given the specificity of each people's history, geography, and present circumstances, nevertheless offers some useful lessons for France and other Old World countries. He is certainly not acting as America's cheerleader; nor however is he anti-American or anti-America. Like Publius in The Federalist (1788), Tocqueville claims, against his countryman Montesquieu, that a democratic republic over a large territory is possible- he has seen it with his own eyes - but he does not claim that democracy, i.e., genuine popular sovereignty with broad participation by ordinary people from all walks 
of life in the policy-making decisions and daily running of the country, is either inevitable, easily sustainable, or without attendant dangers.

Following an early assessment by John Stuart Mill, Volume Two is often said to be darker and denser than Volume One, but I disagree. I find Tocqueville's language and rhetorical techniques to be roughly the same throughout (more on those techniques later). As for the possible negative side effects or "perils" of the "democratic revolution," which Tocqueville says he will not shy away from talking about in Volume Two, especially the specter of a new "hard" industrial aristocracy and a "soft," pseudo-democratic, professional-managerial despotism, they were already evoked in Volume One and perfectly audible for anyone with the ears to hear them. And for those who missed those warnings, there are the two Introductions to Volume One and the Preface to Volume Two. Here is a passage from each, starting with the first Introduction, which includes clear statements of Tocqueville's observations and convictions:

To educate democracy-if possible to revive its beliefs; to purify its mores; to regulate its impulses; to substitute, little by little, knowledge of affairs for inexperience and understanding of true interests for blind instinct; to adapt government to its time and place; to alter it to fit circumstances and individuals - this is the primary duty imposed on the leaders of society today.

A world that is totally new demands a new political science.

To this need, however, we [French and Europeans generally] have given little thought. Immersed in a rapidly flowing stream, we stubbornly fix our eyes on the few pieces of debris still visible on the shore, while the current carries us away and propels us backward into the abyss. (DA I, 61-62, G7)

Tocqueville is clearly frustrated by his generation's inability to carry out the French Revolution's worthwhile program-Liberté, Egalité, Fraternité. A few pages later, he switches metaphors, from river to ruins, to better get across the idea that his countrymen are stuck between an old regime that no longer exists and a new regime that doesn't yet exist:

Thus we have abandoned what was good in our former state without acquiring what useful things our present state might 
have to offer. Having destroyed an aristocratic society, we seem ready to go on living complacently amid the rubble forever. (I, 65, G11)

"All that for this!" Tocqueville laments. The long, disappointing outcome of the French Revolution-from the Terror to Napoleon to Charles X to Louis-Philippe to a Second Republic and then a Second Empire-must be increasingly aggravating as the years go by to the eloquent social scientist elected both to the Chamber of Deputies (1839) and to the Académie Française (1841). "They still don't get it!” must be his upset feeling, and so in the revolutionary year of 1848 he uses the occasion of a 12th edition of his acclaimed masterpiece to say once again that France still has the opportunity to learn from the American example and change course:

America's institutions, which were only a subject of curiosity under the French monarchy, must become an object of study for a republican France. Force alone cannot be the foundation of a new government; good laws are necessary. After the warrior, the legislator. The one destroys, the other founds. To each his work. If the question is no longer whether in France we will have royalty or a republic, we have still to learn if that Republic will be agitated or tranquil, fair and steady or haphazard, pacific or war-mongering, liberal or oppressive, a menace to the sacred rights of property and family or one which recognizes and defends them. This is a terrible problem whose solution is not only important for France but for the entire civilized world....

Yet, this problem, which we have only begun to think about, was solved by the Americans more than sixty years ago [Tocqueville is probably dating from the time of the ratification of the U.S. Constitution: 1788-1848.]

Where indeed could we find greater hope or greater lessons? But let us not turn our attention toward America to slavishly copy the institutions it established for itself, but to better think through those which would be right for us; not necessarily to do what they do, but to learn from what they've 
done; and to borrow the principles more than the details of their laws. (I, 54, my translation)

That this "terrible problem" has been definitively "solved" by the Americans sounds like a gross exaggeration today and probably would have to an American in 1848 as well; but from Tocqueville's perspective it may have looked as though the United States had definitely answered "Yes, we can" to the "important question" asked in the opening paragraph of Federalist \#1, and, who knows, he may even have been inspired by that famous passage and have decided to play the latter-day Madison or Hamilton when, like Publius, he considers the "terrible problem" as an "important question" addressed to his countrymen (whom he also casts in an empowered, decision-making role). Here is Publius:

It has frequently been remarked that it seems to have been reserved to the people of this country, by their conduct and example, to decide the important question, whether societies of men are really capable or not of establishing good government from reflection and choice, or whether they are forever destined for their political constitutions on accident and force.

The stakes are high in 1787 and 1788, as Publius makes clear, and Tocqueville, who served on a Philadelphia-like constitution drafting committee in 1848, raises them further in his new Introduction that also presents a stark choice: A or B.

If we save ourselves, we save all the peoples in our neighboring countries at the same time; if we lose our way, everyone will lose along with us. The destiny of the world will be markedly different depending on whether we come to have democratic liberty or democratic tyranny; and whether republican government is to be eventually established everywhere or abolished everywhere depends today on us. (I, 54, my translation)

That "the destiny of the world" depends on what happens in France is a long-standing conceit of French "exceptionalism" that understandably grates against America's own brand of exceptionalist grandeur; nevertheless, Tocqueville's underlining of the risk of "democratic tyranny" soon 
looked prescient after the decisive electoral victory of President Louis Napoleon, who would soon become Emperor Napoleon III.

To conclude, here is Tocqueville's 1840 declaration from the Preface to Volume Two justifying the full disclosure that he plans to make concerning the possible perils of the "irresistible" democratic revolution:

Since I am firmly of the opinion that the democratic revolution to which we are witness is an irresistible fact, and one that it would be neither desirable nor wise to oppose, some readers may be surprised to discover how often I find occasion in the book to be quite severely critical of the democratic societies created by this revolution.

My answer is simple: it is because I am not an enemy of democracy that I sought to deal with it in a sincere manner.

People do not receive the truth from their enemies, and their friends seldom offer it. That is why I have told it as I see it.

My premise is that many people will take it upon themselves to proclaim the new goods that equality promises to mankind but few will dare warn of the perils that it holds in the offing. I have therefore focused primarily on those perils, and being convinced that I had clearly made them out, I was not so cowardly as to hold my tongue about them.

I hope that readers will judge this second work to be as impartial as they seem to have judged the first. Amid the swirl of divisive and contradictory opinions, I have tried for a moment to forget the sympathies and antipathies that each of them may inspire in me. (II, 6, G480)

By "impartial," I don't think Tocqueville had in mind the so-called balanced reporting one hears about today, but instead an expression of sincere admiration for democracy's "real advantages," as he sees them, as well as a measured, complete account of its real defects and self-destructive tendencies. We will return later to the subject of Tocqueville's theoretical stance and his desire to adopt the more just, less partisan point of view of the Almighty Eternal Being "whose eye necessarily encompasses all things and sees the entire human race and each man distinctly yet simultaneously" (II, 401, G832). 


\section{$\phi$}

The above quotations, even if not in French, offer a fairly representative sample of Tocqueville's language and rhetorical techniques. If it's common for Tocqueville to be the go-to person for a handy quotation, as well as for commentators to marvel at how frequently that happens (Gopnik, Kramnik), fewer have taken the trouble to explain why Tocqueville is so quotable. The obvious answer is that he writes clear, grammatical, idiomatic prose about a complex problem-Is democracy possible and under what conditions? - that interests lots of people. In a letter to his friend Kergolay (November 10,1836), Tocqueville says that he reads a bit of Pascal, Montesquieu, and Rousseau every day. Those are good prose models, and Tocqueville seems to have absorbed from them a thorough knowledge of the moves that matter in persuasive writing that any language teacher or MLA president would be thrilled to see appear in student prose. ${ }^{38}$ Paragraph unity, logical paragraph sequencing, and the judicious use of the standard modes of development taught in any composition class (e.g., narration, description, examples, classification and division, comparison and contrast, process, cause and effect, definition, and argument $)^{39}$ seem second nature to Tocqueville and make his writing both engaging and graceful.

Tocqueville's prose strikes a nice balance between the written and the spoken. It's the prose of an orator, one could say, but not a showy or bombastic one (an American weakness noted in DA II, 1, 18). The prose is straightforward but not demotic or folksy, sharp but not snarky. And though Tocqueville is keen on exposing little-noticed cause and effect relationships, unexpected reversals, and the mechanisms of checks and balances, his presentations generally rank clarity over cleverness, acuity over cute, the tenor over the vehicle. Indeed, his use of metaphor, such as the stream and rubble images quoted above, is restrained, and all the more powerful for its rarity. ${ }^{40}$ Poetic attention-getting devices are unnecessary because he's not Emerson addressing a highly diverse crowd in some rented church or grange hall, but instead a classically educated aristocrat writing to the French "power elite" of his day, whether noble like himself or part of the notable bourgeoisie class. Unburdened by the need to seduce or conform, Tocqueville is free to move forward with 
his argument-driven essay as though he were trying to convince his best friends, siblings, or parents to accept what he has to say, and no doubt in part he was.

Two recurring techniques are worth special mention. The first may be something he picked up from the deadpan Pascal, the pragmatic Publius, ${ }^{41}$ or another political philosopher such as Machiavelli, Adam Ferguson, or Montesquieu. It consists of using probabilistic, noncategorical adverbs (généralement, rarement, souvent, etc.) and dynamic comparative structures such as "either $x$ or $y$ " "the more $x$, the more/less $y$," "when $x$, then/then not $y$," or "if more $x$, then the chances are more/less $y$," etc. Here is an example from a discussion about "How Democracy Simplifies and Eases Habitual Relations among Americans.”

Many people adduce purely physical causes to explain the strikingly unsociable character of the English and their reserved and taciturn nature. I am willing to grant that blood counts for something, but I believe that the social state is far more important, as the American example proves. (II, 212, G661)

This paragraph contains (1) a classic "They say / I say" structure (which here is articulated around a partial concession: "I am willing to grant"), (2) Tocqueville's characteristic use of comparison and contrast, here between vertical aristoland ways and the allegedly more horizontal demoland attitudes, (3) a strong comparative, "far more important," and (4) reliance on a supposed observation of opposite behaviors in a similar situation: two Americans / two Englishmen meet by chance in a foreign place; the former are natural, frank, and open with each other, the latter are stiff and distant. The point Tocqueville wants to make is that democracy favors "weak ties" with their attendant advantages and disadvantages: "Democracy does not create tight bonds among men, but it does make their habitual relations easier," he asserts in the first sentence of the chapter.

A second recurring technique, basic to all oral presentations, is Tocqueville's tendency to conclude each chapter with a tightly organized closing statement that recalls the opening main idea (usually clearly displayed in the chapter title as well). He never goes in for wisecracks, but 
he does like to conclude with a sort of zinger that will have the rousing energy of a sonnet's closing couplet and the memorable impact of a joke's punch line. Thus, the chapter in question concludes with a quick restatement of the whole argument once again:

Americans are as fully aware as we [French] are of the unsociable attitude of the English toward other Englishmen, and no less astonished by it. Yet the Americans are tied to the English by origin, religion, and language, and in part by mores. The only difference is their social state. Hence it seems fair to say that the reserve of the English stems far more from the country's constitution than from that of its citizens. (II, 213, G662)

Whether it really seems fair or not, in 1830, 1930, or 2030, is almost beside the point; because the empirical truth of the matter becomes secondary to the theoretical point that Tocqueville wants us to go along with (i.e., power struggles are more likely between unequals, and conversely); and who wouldn't, especially when the argument is presented in the triangular form of a joke with the American and the French as relaxed allies at the expense of the stiff Englishman?

A second example of a zinger is this conclusion to the comparatively long and complex chapter on "Why Great Revolutions Will Become Rare” (II, 3, 21):

People think that the new societies will constantly be changing their identity, while I am afraid they will end up all too invariably attached to the same institutions, the same prejudices, and the same mores, so that the human race will stop progressing and narrow its horizons. I fear that the mind will forever subdivide itself into smaller and smaller compartments without producing new ideas, that man will exhaust his energies in petty, solitary, and sterile changes, and that humanity, though constantly on the move, will cease to advance. (G760)

Here we have another variant of the "They say / I say" template: people think $x, \mathrm{I}$ am afraid of precisely the opposite of $x$, I fear $y$. Also, with the juxtaposition of "though constantly on the move, will cease to advance," we get an example of what Adam Gopnik (himself a lover of chiasmus) 
calls Tocqueville's obsession with tracking "this oscillation of opposites in America...following the American boomerang in action" (25). I agree with that assessment as well as with his remark that Tocqueville exhibits a keen desire to show that seeming contradictions or paradoxes (e.g., American people are moving about but not getting anywhere) are really perfectly logical upon closer inspection. In sum, Tocqueville's dynamic rhetoric is well suited to depicting both the more clearly graspable and the less easily comprehensible aspects of democracy in America.

\section{Q}

Democracy in America contains roughly twenty-five big ideas and about a hundred smaller ones that follow from the major "considerations" as he calls them. One of the most important of the top twenty-five is the fact that in America religion and liberty are mutually reinforcing and not mutually exclusive as commonly believed in certain quarters of postEnlightenment France and other dens of Europe. ${ }^{42}$

Tocqueville comes back to the subject of religion's fundamental necessity, centrality, and usefulness for democracy many times in both volumes. ${ }^{43}$ By religion, Tocqueville means a system of beliefs, such as one finds in any of the Christian denominations, but he is not proselytizing. Nothing he says in favor of religion's complementary relationship with a spirit of freedom and democratic practices would seem to exclude, for example, Buddhism or any other religion so long as it meets the important condition of sticking to its own transpersonal, immaterial, eternal plane. ${ }^{44}$ Religions that meddle too much in the world, says Tocqueville, are acting like political parties and will be treated as such and gradually lose their other-worldly source of attraction and thereby atrophy (see DA II, 1, 5).

In his bicentenary tribute Tocqueville Aujourd'hui (2005), Raymond Boudon notes that $96 \%$ of those living in the "land of the free" believe in God, $93 \%$ believe in the soul, and $87 \%$ believe in Heaven - statistics that astonish many French people, and the more higher education they have, the more likely they are to chuckle, shake their heads, and declare that Americans are manifestly not free if they believe that! And yet, if they only read Tocqueville, they would see that there's a tension but no contradiction or incompatibility between liberty and belief. As Tocqueville 
sees it, religious belief (i.e., dogma) frees up disk space, so to speak, and allows Americans to think and act freely and creatively in other areas once certain spiritual matters are settled and secure. And yet, although he sees that this practice of turning off one's mind in one area so that "liberté d'intelligence" can flourish in other areas is for most people a "healthy yoke" (joug salutaire, II, 30), he says he would prefer not to wear it himself; and he also notes that it always risks going too far, becoming too constraining, and ending all thought. ${ }^{45}$

Despite the possibility and drawbacks of excess conformism, a "genteel" tendency that also worried Emerson, Thoreau, and some other nineteenth-century Americans who were of two minds about the costs and benefits of the Second Great Awakening then sweeping the country, Tocqueville does not see much practical evidence in 1831 that religion has caused Americans to behave like brainwashed drug addicts as Marx famously opined. In Tocqueville's view, besides indirectly stimulating brain activity and economic productivity, religious belief checks democracy's three worst negative side effects: excess individualism, materialism, and nowism (G503). Most of the time, demolanders recognize and embrace this regulatory function that religion has to improve their lives_it's part of their "self-interest properly understood" as Tocqueville says (DA II, 2, 8). A healthy democracy respectfully acknowledges that religion provides life-affirming nourishment to the spirit (soul or mind) of man. Religion is chicken soup, not opium, would be Tocqueville's point when he says, "Unbelief is an accident, faith alone is the permanent condition of humankind." 46 Or when he declares in one of the most frequently quoted lines from Democracy in America:

For my part, I doubt that man can ever tolerate both complete religious independence and total political liberty, and I am inclined to think that if he has no faith, he must serve, and if he is free, he must believe. ${ }^{47}$

This and similar pronouncements may account for why Tocqueville is largely inaudible for the French, especially French Marxists, and this notwithstanding the loud efforts of Tocqueville's top admirer in twentieth-century France, Raymond Aron, whose L'Opium des Intellectuels (1955) owes much to Tocqueville. Following Aron, Raymond Boudon 
concludes his admiring study with the observation that Tocqueville's messages are "not pleasant to hear, but deserve to be listened to." That they have not been able to compete against France's "pensée unique"48 (whether expressed by the Left or the Right) illustrates another tension that Tocqueville explains in the chapter "On the Omnipotence of the Majority in the United States and Its Effects" (I, 2, 7); namely the fact that strong majorities are necessary to get things done but frequently harmful to minorities and intolerant of opposing views.

The short explanation of the majority's omnipotence constitutes Tocqueville's second big idea: When the majority recognizes no higher authority (e.g., the rule of Law, Justice, God) and "sheer numbers makes right" comes to look like an adequate replacement for "might makes right," then majority public opinion in a democracy can acquire an inflexible self-righteousness, intolerance, and omnipotence that can be as ruthless and destructive as old-style authoritarian and totalitarian regimes, whether secular or religiously inspired. ${ }^{49}$ Tocqueville's longer answer is excerpted here:

I know of no country where there is in general less independence of mind and true freedom of discussion than in America...

In America, the majority erects a formidable barrier around thought. Within the limits thus laid down, the writer is free, but woe unto him who dares to venture beyond those limits. Not that he need fear an auto-da-fé, but he must face all sorts of unpleasantness and daily persecution. He has no chance of a political career, for he has offended the only power capable of opening the way to one. He is denied everything, including glory. Before publishing his opinions, he thought he had supporters, but having revealed himself to all, he finds that his support seems to have vanished, because his critics voice their opinions loudly, while those who think as he does but who lack his courage hold their tongues and take their distance. In the end, he gives in, he bends under the burden of such unremitting effort and retreats into silence, as if he felt remorse for having spoken the truth... 
Tyranny in democratic republics ... ignores the body and goes straight for the soul. The master no longer says: You will think as I do or die. He says: You are free not to think as I do. You may keep your life, your property, and everything else. But from this day forth you shall be as a stranger among us. You will retain your civic privileges, but they will be of no use to you. For if you seek the votes of your fellow citizens, they will withhold them, and if you seek only their esteem, they will feign to refuse even that. You will remain among men, but you will forfeit your rights to humanity. When you approach your fellow creatures, they will shun you as one who is impure. And even those who believe in your innocence will abandon you, lest they, too, be shunned in turn. Go in peace, I will not take your life, but the life I leave you with is worse than death. (I, 353-354, G293-294)

Nowhere else does Tocqueville allow himself to be as over-the-top theatrical as here. And you don't have to be Kafka or Orwell to know what kind of persecution he is talking about. The subtle ostracism and alienation that the omnipotent majority can provoke is familiar to anyone who has uttered, published, thought, or done something that goes against the mores of a dominant group. ${ }^{50}$

A third and perhaps the biggest of Tocqueville's big ideas is the one announced in the very first sentence of the Introduction: "Among the new things that attracted my attention during my stay in the United States, none struck me more forcefully than the equality of conditions" (I, 57, G3). By "equality of conditions," Tocqueville does not mean that he witnessed a "classless society" composed of a single, massive middle class with no rich or poor. It is true however that the 1830s era of "Jacksonian Democracy" was a time of increasing egalitarianism (at least if one considers white males and overlooks the unequal civil rights and socioeconomic standing of women, blacks, and Indians - something Tocqueville both does and does not do). What he means is that the Anglo Americans and Euro Americans he met were a rather homogeneous lot with roughly the same "point of departure," outlook on life, and aspirations.

If America is the land of the free and at the same time a country of believers, few have claimed that it is also "the land of the equal"; and yet 
Tocqueville insists that equality of conditions strikes him as the "original fact [fait générateur] from which each particular fact seemed to derive. It stood constantly before me as the focal point toward which all my observations converged" (DA I, 57, G3). Some may reject this claim out of hand because for them (like for nineteenth-century feminists, 1960s civil rights activists, or recent observers such as Thomas B. Edsall, Timothy Noah, Joseph E. Stiglitz, and the chorus of Occupy Wall Street protestors) American inequality is so glaringly obvious and painful. However, they may be forgetting that from Tocqueville's perspective (a French aristocrat living under a constitutional monarchy of distinct social classes and highly restrictive rights to vote, assemble, and publish) America was comparatively very egalitarian. Aside from the predicaments of women, blacks, and Indians whose situations Tocqueville brackets but does not ignore, Americans look like a happy band of self-reliant, motivated citizens living out the revolutionary idea/l that "Men are born and remain free and equal in rights." ${ }^{11}$ Meanwhile in France in 1835, where even white males look and behave more like "administrated units" ("des administrés" $D A \mathrm{I}, 131)$ than citizens, that 1789 declaration may have sounded like a broken promise or "bad check" as Martin Luther King, Jr., would say in 1963 about America's insufficient investment in emancipation and equal rights for all. At any rate, it sort of kills the whole experience of reading Democracy in America if one is not willing to grant, at least provisionally, Tocqueville's lead-off claim that the American "état social" is one of "très grande égalité" and therefore "éminemment démocratique" (DA I, 107), at least when compared to France, England, and many other parts of nineteenth-century Europe.

\section{$\phi$}

In addition to the big three-1. religion and liberty are mutually reinforcing and not incompatible ( $D A \mathrm{I}, 1,2)$, 2. majority rule is both necessary (to get things done) and potentially dangerous (DA I, 2, 7), and 3. equality is real (DA I, 1, 3) - here now is a list of Tocqueville's other big ideas, many of which, as he says himself, derive from the "generating fact" of the unprecedented levels of equality he witnessed in 1830s America:

A social state of equality where ordinary people are, taken singly, all relatively weak, gives rise to individualism, a rational concern for the 
security and well-being of oneself and an intimate circle of family and friends (II, 2, 2).

Equality both loosens and softens the habitual relations (mæurs) between otherwise hierarchically opposed groups: master/servant, husband/wife, father/son, employer/employee, officer/soldier (II, $3,1-5,8-12)$.

Communal spirit (esprit communal) is the key to the success of local and national politics in America because it builds healthy, productive feelings of pride ("We built this city"), co-ownership as stakeholders, and shared responsibility and accountability. Local politics is the crucible of self-governance where particular private interests and general public interests overlap in the "public sphere" to decide and pursue projects for the commonwealth (I, 1, 5): "C'est sur la place publique et dans le sein de l'assemblée générale des citoyens, que se traitent, comme à Athènes, les affaires qui touchent à l'intérêt de tous" (I, 1, 2, 100, G46).

By extending equal rights (to speech and assembly) to all, and protection under the rule of law, a democracy offers religious practitioners a safe haven and the freedom to be different; while religions, by standing as examples of an orderly community of equals with common interests that celebrate in some form or other the infinite, the immaterial, and the transpersonal, usefully counteract democracy's negative tendencies, notably excess individualism, materialism, and nowism, by periodically turning people's attention away from themselves, from money and next Monday. With their various distinct codes and beliefs, some of which can strike outsiders as offensive or just bizarre, religions also counter democracy's inclination to suppress difference, especially thinking and acting differently, and to require conformity (in the name of "law and order," "discipline," or "equality," or out of secret envy or brute stubbornness) (I, 2, 9; II, 1, 5; II, 2, 15).

Excess individualism and the constant pursuit of personal well-being or eccentric passions can kill off local communal spirit and national solidarity (also known as rational patriotism), and therefore must be checked by religious services and other freely engaged in (and free or low-cost) social institutions and practices such as the postal service, newspapers (today of course "the Web": "the world's largest public resource"), civic associations that entail physical bodies coming together and not just 
ideas, including political parties, public libraries, parks, museums, and schools, as well as elections and jury duty that Tocqueville called "a free school, and one that is always open" and "one of the most effective means available to society for educating the people” (I, 376, G316).

Despite its negative aspects, democracy also has real advantages, the first being that it knows it has faults (including a penchant for waste, haste, recklessness, forgetfulness, and mediocrity), something an aristocrat has more difficulty admitting to since it's so easy to equate being the best (aristoi) with being perfect and being grand with grandeur. Other real advantages of democratic government that Tocqueville names are looking out for the well-being of the greatest number without needing to rely on virtuous supervisors (who may be in short supply); building a publicspirited "rational patriotism" (patriotisme réfléchi, I, 330) where private and public as well as local and national interests (a road or railroad, a water treatment facility, etc.) are "properly understood" (bien entendu) as necessary and necessarily overlapping; building respect for rights and law; building self-reliance and self-esteem; getting a lot done (even if what gets done is not always of the highest quality or the most durable); and making repairable mistakes (I, 2, 6).

Democracy may lack some grandeur and beauty, but it is more just, and justice is grand and beautiful (II, 4, 8, 401).

People living in a democracy can be petty, envious, resentful, vindictive, shortsighted, impatient, inattentive, reckless or timid, bombastic or mousy; but they also can be honest, fair, open, relaxed, spontaneously helpful, generous, caring, and brave. And of course self-reliant and practical - two of the most commonly cited character traits of Americans, neither of which is prominent in aristolands since affirming the individual, ordinary self is practically heresy (le moi est haïssable), and being practical is simply not a priority ${ }^{52}$ (II, 1,1 ; II, 1, 10-12).

People living in democratic times feel relatively equal, including all relatively weak and insecure, and therefore they tend to want to get the most they can now with the least effort and the least risk of loss (II, 1, $3,25)$. Therefore, demolanders can be tempted to passively make do ("You get what you get and you don't get upset") or do things on the cheap ("That's good enough"); or sign over their right to self-governance to a professional-managerial class of "brainworkers" (humans, animals, 
or machines); i.e., accepting "voluntary servitude," "outsourcing," and the "yoke" (joug) of "soft despotism" ("despotisme plus étendu et plus doux"); or they may remain children or revert to egocentric, childlike behavior, such as demanding scrupulous equality down to the smallest details: “That's not fair!" "Why does she get that?" (II, 4, 6).

Monopolies and specialization in commerce and industry (the professional pursuits of most demolanders) could lead to the emergence of a new "aristocracy" that would be just as draining and brutalizing for those at the base of the pyramid as during the Old Regime, but also more relentless and pitiless since this new overclass, these proud "captains of industry," would have none of the traditional feelings of paternal obligation to lighten the miseries of those it exploits. "Are there no prisons?" asks the hard-hearted Scrooge before his rebirth. "Are they my poor?" asks Emerson in one of his tough stances in the essay "Self-Reliance" (II, 2, 19-20).

While honor in aristocratic societies is derived from conquest in battle, or from being a descendant of a successful warrior (Tocqueville could trace his family back to William the Conqueror!), honor in democratic societies comes from work, and for democrats all work is honorable, although the most honor tends to redound to those whose activities earn the most money (II, 2, 10).

Since democratic honor is derived principally from building and selling stuff (industry and commerce) and not war, a democratic society has two good reasons to want to avoid war: 1) it's not exactly honorable, since the work of war is conquest, which is a predatory form of taking (life, treasure, territory) and not making; and 2) it disrupts the work of everyone else (i.e., it's bad for business). The only group in a democracy that wants war is the army (especially those at the lower and middle ranks, who have little or no property at stake and few civilian career prospects), since it is their chance to do their job (kill and conquer) and get ahead (with medals and promotions thanks to victory and attrition). In modern times Tocqueville's analysis would have to be expanded to include individuals and groups such as defense contractors and arms dealers that benefit from protracted or endless "foreign entanglements" that transform the traditional nonmilitary economy into a "military-industrial complex" 53 (II, 3, 22-25). 
On the question of freewill and determinism, Tocqueville has an intermediate position, close to Emerson's declaration in the essay "Fate," that affirms man's free willl while acknowledging certain physical constraints (e.g., having lungs and not gills):

Nor can he [man] blink the free will. To hazard the contradiction,- - freedom is necessary. If you please to plant yourself on the side of Fate, and say, Fate is all; then we say, a part of Fate is the freedom of man.

Thus, when it comes to history and historiography (II, 1, 20), Tocqueville is as opposed to giving all the credit to "great men" as he is to giving it all to "forces," but he adds it is also probably true that in democratic times "general facts" are more influential, whereas in ages of aristocracy "particular influences" explain more. This may be why Tocqueville forgoes almost all personal anecdotes in Democracy in America, whereas in his two other books, Souvenirs and Ancien Régime, concentrating as they do on aristocratic-minded France, a particular individual action (or inaction) receives much more attention. The following passage is a good example of Tocqueville's compare and contrast technique and his attention to the specific characteristics of different circumstances.

I am firmly convinced that, even in democratic nations, the genius, vices, and virtues of certain individuals can delay or hasten the fulfillment of a people's natural destiny. But these kinds of fortuitous and secondary causes are infinitely more varied, more hidden, more complicated, less powerful, and consequently more difficult to sort out and trace in ages of equality than in centuries of aristocracy, where the only problem is to analyze the particular action of one man or a small number of men within a general context...

My own view is that in every period some of the events of this world must be ascribed to very general causes, others to very particular ones. Causes of both kinds are always encountered; the only thing that differs is their relative importance. General facts explain more things in democratic centuries than in aristocratic ones, and particular influences explain less. In ages of aristocracy, the opposite is true... 
Historians who seek to describe what goes on in democratic societies are therefore right to pay a great deal of attention to general causes and to devote their primary effort to uncovering them, but they are wrong to deny the particular actions of individuals simply because it is not easy to find these out or trace their effects. (II, 2, 20, 108, G570)

At the end of this chapter Tocqueville clearly opposes the "doctrine of fatality" that underpins historiography in democratic times, and concludes with a zinger that affirms man's free will:

A glance at the histories written nowadays would suggest that man has no power over either himself or his surroundings...

If this doctrine of fatality, which is so attractive to those who write history in democratic times, were to spread from writers to readers and thereby infiltrate the citizenry en masse and take hold of the public mind, it would soon paralyze the new societies and reduce Christians to Turks.

I would add, moreover, that such a doctrine is particularly dangerous at the present time. Our contemporaries are only too ready to doubt the existence of free will because as individuals they feel frustrated by their weakness no matter which way they turn, yet they are still quite prepared to recognize the strength and independence of men joined together in a social body. One should be careful not to obscure this idea [of free will], because the goal is to exalt men's souls, not to complete the task of laying them low [car il s'agit de relever les âmes et non d'achever de les abattre]." (II, 110, G572)

Turks need not feel too personally attacked here, since Tocqueville is using that group as a rather arbitrary heuristic mechanism, just as Montesquieu made use of Persians, and the Chinese served as a negative example for the Scottish philosopher Adam Ferguson (and for Tocqueville as well in DA II, 1, 10). In each case the other culture, depicted as a static block, serves as the vehicle to send a message to one's own countrymen about the potential for paralysis and stagnation should they stop believing in freedom and acting freely. ${ }^{54}$ 
A group that has more reason to feel prickly about Tocqueville's closing remarks are structuralists, especially the twentieth-century Annales school of French historians whose emphasis on social structures as explanatory forces downplayed the political decisions of "great men" emphasized in much nineteenth-century historiography. One may raise an eyebrow, however, and point out the irony of Tocqueville's admonishing conclusion given the crucial importance for his whole enterprise of the "generating fact" of the "social state" of "equality of conditions" in America. Or one may see this as a sign of Tocqueville's self-awareness and insight about the balancing act and unresolved tension-because perhaps unresolvable - that he and all historians must accept as their unavoidable individual responsibility.

"Nothing is harder than learning to be free." By contrast, learning to accept despotism is easy. Why? Because although people would like to be both free and equal, they tend to have a stronger passion for equality than they do for liberty (I, 1, 3; II, 2, 1). What's more, they will more readily give up freedom if they are convinced it is incompatible with equality, or if they come to think it's a good idea to trade in their freedom for the law and order that they deem necessary for their security and well-being. Tocqueville explains how this works in the following passage from the "Real Advantages of Democratic Government" chapter:

$[\mathrm{N}]$ othing is harder than the apprenticeship of liberty. This is not true of despotism. Despotism often presents itself as the remedy for all ills suffered in the past. It is the upholder of justice, the champion of the oppressed, and the founder of order. Nations are lulled to sleep by the temporary prosperity to which it gives rise, and when they awake, they are miserable. Liberty, in contrast, is usually born in stormy times. It struggles to establish itself amid civil discord, and its benefits can be appreciated only when it is old. (I, 335, G275)

Like all romantic moralists from Emerson to Oscar Wilde to Jacques Derrida to today's op-ed columnist, Tocqueville is sure that he's wide awake, but others are dozing or blind. For Tocqueville, there are really two passions for equality, one "manly and legitimate," the other a "depraved taste for equality" provoked by envy and resentment in the 
human heart (I, 1, 3). The following passage that distinguishes these two types of equality is frequently quoted:

There is in fact a manly and legitimate passion for equality that spurs all men to wish to be strong and esteemed. This passion tends to elevate the lesser to the rank of the greater. But one also finds in the human heart a depraved taste for equality, which impels the weak to want to bring the strong down to their level, and which reduces men to preferring equality in servitude to inequality in freedom. Not that people whose social state is democratic naturally despise liberty; on the contrary, they have an instinctive taste for it. But liberty is not the principal and constant object of their desire. What they love with a love that is eternal is equality. They lunge toward liberty with an abrupt impulse or sudden effort and, if they fail to achieve their goal, resign themselves to their defeat. But nothing could satisfy them without equality, and, rather than lose it, they would perish.

Furthermore, when citizens are all almost equal, it becomes difficult for them to defend their independence against the aggressiveness of power. As none of them is strong enough to fight alone with advantage, the only guarantee of liberty is for everyone to combine forces. But such a combination is not always in evidence. (II, 115-116, G60-61)

In other words, it's not easy for individuals who are all relatively weak to combine forces, even if the goal is liberty, without giving up some liberty now in the hope of getting back that liberty, and more, later. But some sacrifices and compromises are more costly than others. (Think of the typical "wage slave" or of the workhorse Boxer in Animal Farm.) The Americans, Tocqueville says, are lucky that their circumstances and especially their mores have allowed sovereignty of the people to endure for more than sixty years; but other people, such as his countrymen, have not been so fortunate or wise.

Furthermore, the passions for equality and liberty are at their highest among peoples who are experiencing or have recently experienced a social revolution, because the taste of greater equality can feed expectations for 
yet more equality, and suddenly requests turn into demands, and wishes become rights... or riots (II, 2, 3). Similarly, says Tocqueville, a taste of greater equality can provoke greater amounts of anger and frustration toward any subsisting inequalities - an attack that the dominant may fend off with the mocking put-down "uppity." These matters are treated in the chapter on "How Democracy Modifies Relations Between Servant and Master" (II, 3, 5) and have lost none of their pertinence.

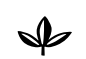

Another topic that has attracted more attention from recent commentators is Tocqueville's admiration for American women. ${ }^{55}$ One may wonder, however, if this admiration is based less on what they are-which is terribly unequal and unfree compared to their white male counterparts - and more on what they have not become, which is a mob of angry, revenging Medeas.

Tocqueville believes that women set the mores in a given society ("c'est la femme qui fait les mours," II, 3, 9, 247). Therefore, to know what those mores are and how they work, which for Tocqueville is the key to understanding that society, one must investigate the status and habits, thoughts and feelings of women. He recalls that in America there is a liberal constitution and a democratic social condition, and these give young American women more autonomy than anywhere else in the world. He notes that all American youth, including women, are nudged toward independence early on, and this is viewed as normal and correct by both children and their parents (II, 247). The education of young women is allowed, and it is not as prettified or watered down as in aristocratic lands. ${ }^{56}$

In France where our opinions and tastes are still a strange mix combining vestiges of all the ages of the past, we often give women a timid, sheltered, almost cloistered upbringing, and then we suddenly abandon them, without guidance or assistance, to the disorders that are inseparable from democratic society. (II, 248, G693)

In the U.S., on the other hand, women are given the chance, via education, to defend themselves in a world that all Americans know can be disorderly, competitive, and cruel. Young American women are not kept 
from knowing "the corruptions of the world" ("les corruptions $d u$ monde," II, 249, G693). Tocqueville admires that in America religious training is not used merely to defend the virtue of women, but to arm her reason ("armer sa raison"). He finds this training produces women who are more respectable and cold ("honnêtes et froides") than tender and loveable, but he admires them nonetheless. He sees it as a trade-off: the education of American women makes for a more tranquil and better regulated public sphere, but it may come at the price of a rather less charming domestic sphere. ${ }^{57}$ But he concludes these imperfections are "secondary ills, which ought to be braved for the sake of a greater interest." (G694) Ultimately Tocqueville is firm in his praise of the American model when it comes to the education of women: "a democratic upbringing is necessary to protect women from the perils with which the institutions and mores of democracy surround them" (G694). In other words, it's precisely because democratic equality and liberty provoke "secondary evils" [ maux secondaires] — games of seduction, single mothers, unwanted pregnancies, underpaid employment, sexual harassment and assault, sexual discrimination, deadbeat absent fathers - that women have to be armed to face those eventualities, and developing their thinking capacities and self-reliance is the best possible hope for their future survival and prosperity and for the future of democratic institutions.

"The Education of Young Women in the United States" (II, 3, 9), is an uplifting chapter that any woman aspiring to live free would find exhilarating to read. But there is also a larger message of hope here, and one not solely addressed to women; namely that democracy's vices must be answered with more democracy, not resignation or renunciation. Tocqueville will have more to say about this in the final admonitory chapters of Volume Two. Before turning to Tocqueville's description of a possible, future "soft despotism" in democratic societies (the single most interesting part of the book for many of Tocqueville's Cold-War-era commentators), it's worth saying a bit more about the real and present soft despotism endured by American women to which Tocqueville devotes three more chapters (II, 3, 10, 11, 12).

In DA II, 3, 10 Tocqueville extends his cost-benefit analysis of the education American women receive. He also reviews the situation within the marriages that they partly choose and partly have forced on them (by 
the strict mœurs and low horizon of expectations within American society that they inherit and transmit without getting to choose or rewrite them freely). Generally, married American women are obliged to keep a stiff upper lip; i.e., they must be stoically pragmatic and forward-looking, not emotional or complaining about the marriages they inhabit. He observes a widespread you-made-your-bed-now-lie-in-it attitude that leaves little room for public lamentation over their lot or self-pity among the women themselves. One gets the impression, he says (whether he believes this conceit is another matter), that the American woman enters freely into her marriage and must accept the consequences, especially the low level of social liberty (and professional opportunity) outside the domestic circle: "She has been taught in advance what is expected of her, and she accepts the yoke freely and of her own accord. She bears her new condition bravely because she has chosen it." ${ }^{58}$ Note the recurrence here of the freely accepted yoke that Tocqueville had earlier spoken of approvingly in the discussion of the benefits of accepting religious dogma, though he demurred that he would not want to wear that yoke himself ${ }^{59}$ (II, 19, G493).

In DA II, 3, Chapter Eleven, Tocqueville explains how equality of social conditions contributes to the enduring regularity and loyalty among married people in America. His short explanation (259) is that women and men are too busy pursuing material advancement to have extramarital affairs. Two other contributing factors are (1) that women and men occupy different spheres (domestic / public) and therefore don't have a lot of opportunities for meeting other potential sexual partners (259), and (2) women in democratic societies have more education about "les corruptions $d u$ monde" and they are therefore better equipped to make an intelligent choice and are allowed greater freedom to make that choice. Therefore, once the choice is made there is the feeling of a contract that must be honored.

The strictness of the Americans is partly a consequence of this. They see marriage as a contract which, though often onerous, must be rigorously respected, because the parties had the opportunity to study all of its provisions in advance and were entirely free to refrain from entering into any agreement at all. ${ }^{60}$ 
In aristocratic lands, on the other hand, marriage is often an even colder contract, not the product of a hot passion considered in tranquility; it's a legal bond to unite property, not a spiritual union of hearts (257). Therefore the need for full disclosure (of one's heart and soul) is not deemed necessary (bank accounts and birth certificates suffice), nor is there the same importance given to marriage vows and fidelity. Infidelity is in fact common, an open secret, for it is considered the heart's compensation for what the law forbids - passion's revenge on property. ${ }^{61}$ Tocqueville then shares in a longish footnote his explanation for why in aristolands there are romance novels where extramarital love affairs are often sympathetically represented to the reader as the just outcome or circumvention of overly restrictive social mores; whereas in demolands there are few such books since their laws and social habits do not permit the creation of this opposition between passion and property, true love and arranged marriage- - since they despair of making irregularity likeable" (G700). English wife notwithstanding, Tocqueville seems not to have delved much into the complexities of Jane Austen or other so-called women's fiction that exploits the easy likeability of irregularities.

Returning to firmer ground, Tocqueville adds a further remark about how fighting against one's social condition tends only to be pursued by the mad, or pushes one toward madness (think Romeo or Hamlet), and why it is therefore that revolutionaries (especially those involved in allegedly necessary, saintly revolutions) are rarely moderate and honest but instead extremists and outlaws (258). He then repeats his conviction about the lack of dreaminess among democratic peoples. "No one is less given to reverie than the citizens of a democracy, and few are keen to abandon themselves to the kinds of idle and solitary contemplation that usually precede and provoke major agitations of the heart." ${ }^{62}$ In other words, it takes leisure and security (which aristocrats have more of than democrats) to indulge in the reveries that are the precursors to great loves (whether of men, women, ideas, or causes). Besides missing out on Jane Austen, Tocqueville would seem to have underestimated Rousseau's following in America. ${ }^{63}$

Tocqueville concludes this chapter with the claim that the French Revolution did more to strengthen the morals of the aristocracy than it did those of the revolutionaries themselves. The aristocrats had been 
dissolute and became more orderly, he notes, while the popular classes, who had been more orderly under the Ancien Régime, become more dissolute (261). In the final paragraph he expresses the belief that eventually, when all the consequences of the democratic revolution have played themselves out - whenever that may be - all classes will be less tumultuous and more orderly in their mours. In the meantime, Tocqueville writes approvingly again of the American situation: it may lack sex appeal, but that lack is more than compensated for, he claims, by the benefits of peace, moderation, and regularity (259). His account can sound a bit stodgy, however, like the buttoned-up world of Mr. Banks before the arrival of Mary Poppins.

In the next chapter (DA II, 3, 12), Tocqueville explains how in America men and women have not sought to be completely equal, and he says this would have been a mistake anyway since it would have led to weak men and dishonest women (II, 263). Instead they occupy separate "circles,"-presumably "separate but equal"; i.e., a version of the argument later used in the 1896 Plessy vs. Ferguson decision that rationalized black/white segregation in the decades following the American Civil War. For Tocqueville, this state of affairs is another example of the softening of mours in democratic lands with greater equality of social condition, just like the rapprochement between fathers and sons and masters and servants. There's a raising of the low and a lowering of the high in all three cases, a movement to a more moderate, horizontal middle ground with a proliferation of the supposedly free contract as mediator. Tocqueville envisions a future equality between the sexes: "I think that the social movement that is bringing son and father, servant and master, and, in general, inferior and superior closer to the same level is raising woman and will make her more and more the equal of man." ${ }^{4}$

But "l'égale de l'homme," he insists, does not mean doing all the same things as men. ${ }^{65}$ Tocqueville's feminism is the 1830s "separate spheres" kind, not the American or French feminism of the 1960s and '70s. It is also far from today's more self-aware contested discourses in this area of "gender trouble." Tocqueville uses metaphors (cercle, sphère) that are still being used today by many men (and some women) to divide and conquer, even though for two generations now others have "deconstructed" this naturalization of political choices as part of their critique of the 
separate and unequal power of men and women in America, France, and elsewhere. ${ }^{66}$

In the second half of this chapter, Tocqueville piles on yet more praise, as though he felt obliged to make up for others' contempt, noting that American respect for women is often more genuine and less hypocritical than European attitudes.

It has often been observed that in Europe the flattery that men lavish on women conceals a certain contempt. Although the European male may frequently allow himself to be enslaved by women, he plainly never thinks of these women in a sincere way as his equals. (II, 265, G707)

Perhaps the most memorable sentence in this chapter comes on the next page where Tocqueville applauds the long, fearless, solitary voyage of young American women: "In America a young woman undertakes a long voyage alone and without fear." ${ }^{67}$ Or with fear and maybe a lot of anger too, if one thinks of unwed teenage mothers. Or of slaves. But of course it's more uplifting to think instead of Margaret Fuller, Louise May Alcott and her "Little Women," Elizabeth Peabody, Harriet Beecher Stowe, or Edith Wharton-the kind of exceptional self-reliant women who no doubt impressed Tocqueville during his nine-month journey.

Tocqueville concludes this chapter with his highest praise yet, casting his one vote ("I, for one") for American women as the key to American prosperity and the vigorous growth of the American people- the implication being that millions of others either don't care, do care but don't vote, or would just plain vote against such a proposition:

I, for one, do not hesitate to say that although women in the United States seldom venture outside the domestic sphere, where in some respects they remain quite dependent, nowhere has their position seemed to me to be higher. And now that I am nearing the end of this book, in which I have described so many considerable American accomplishments, if someone were to ask me what I think is primarily responsible for the singular prosperity and growing power of this people, I would answer that it is the superiority of their women. ${ }^{68}$ 
It's understandable and hardly original that Tocqueville bets on Christian values, and women as the main carrier of those values, to found and secure a new harmonious democratic civilization in fallen Europe. The tradition mariale (both Mary Magdalene and the Virgin Mary) has a very long history within fallen Catholic Europe as does the Church's ability to overlook its own contributions to that downfall. Thus, viewed from America today, such highfalutin' declarations have the appearance of what the French call "évacuation par le haut"; i.e., it looks as though the American woman is being kicked upstairs, which may be better than being kicked outside or being kicked all the way across the Mississippi River onto the Western plains like the Indians. But it's perhaps small consolation for someone to receive those injuries in the form of compliments instead of insults. Faced with the cruel irony that was not uncommon within the brutally civilized American genteel tradition, one has to admire the fortitude of the women who banded together in the ensuing decades to invent and struggle for more human dignity for themselves while also mourning the loss of those who desperately went off the deep end toward madness, murder, suicide, or self-exile. ${ }^{69}$

\section{Q}

If I have devoted so many pages to Tocqueville's views on women and their social state within an American society dominated by AngloAmerican males, it is because that case-even more perhaps than the cases of the Indian and the Negro that were considered at length near the end of Volume One $(I, 2,10)$ - is the play within the play, the microcosm, the synecdoche of the larger story that Tocqueville wants to tell about man's humanity or inhumanity to man, and the role that democracy can play in promoting one or the other depending on whether the accent is on democratic liberty or democratic tyranny-with the added difficulty of not always being able to tell which is which (since one person's police state can be another person's "homeland security"). It is my view that this focus on interpersonal relations will rightly become the most fruitful area of borrowing and learning from Tocqueville in the post-Cold War Internet age.

After this long digression through sexual politics, Tocqueville turns back to politics in general (i.e., questions of power distribution and 
policy-making) in the fourth and concluding section of Volume Two. The main ideas, abundantly developed by Cold War commentators so I can be brief, are these: (1) in times of expanding equality of social conditions, total government (tyranny) is more to be feared than no government (anarchy); (2) it is easier to establish despotism in times of equality than in times of inequality; because (3) democracy favors the concentration of power (and the elimination of intermediary powers) more than aristocracies whose members are each jealously attached to their own local privileges and will not yield their regional power without a fight; and (4) if auxiliary precautions are not taken to check and counterbalance the negative tendencies of democratic peoples (especially the tendency to become totally caught up in the pursuit of one's well-being, including saving for retirement and doing all one can to insure an "accessible future" for one's own children), demolanders will not find their country invaded by a tough foreign despot, but will instead select one or a few from within their ranks to whom they will sign over their liberty in exchange for having the complex and time-consuming business of governance taken off their hands because now they are simply too busy with their own affairs to treat common things in common as their less stressed out ancestors may have done. These homegrown mild despots will invariably be seen as regular, middlebrow people, "someone you could have a beer with," and they may or may not have the well-being of the greatest number uppermost in their thoughts. But whatever they really think, do, or get done, Tocqueville predicts they will all feign a strong allegiance to the values of equality, liberty, and justice for all.

For many, the climax in Part Four, and certainly one of the most frequently quoted passages of the whole book, comes in these paragraphs from Chapter Six, "What Kind of Despotism Democratic Nations Have to Fear," that directly follow a preliminary review of how traditional despotism worked in Antiquity.

If despotism were to establish itself in today's democratic nations, it would probably have a different character. It would be more extensive and more mild [plus étendu et plus doux], and it would degrade men without tormenting them.

I have no doubt that in centuries of enlightenment and equality like our own, it will be easier for sovereigns to gather 
all public powers into their hands alone and to penetrate the sphere of private interests more deeply and regularly than any sovereign of Antiquity was ever able to do. But the same equality that facilitates despotism also tempers it. As men become increasingly similar and more and more equal, we have seen how public mores become milder and more humane. When no citizen has great power or wealth, tyranny in a sense lacks both opportunity and a stage. Since all fortunes are modest, passions are naturally contained, the imagination is limited, and pleasures are simple. This universal moderation moderates the sovereign himself and confines the erratic impulses of his desire within certain limits....

Democratic governments may become violent and even cruel in certain moments of great effervescence and great peril, but such crises will be rare and temporary.

When I think of the petty passions of men today, of the softness of their mores, the extent of their enlightenment, the purity of their religion, and the mildness of their morality, of their laborious and orderly habits, and of the restraint that nearly all of them maintain in vice as well as in virtue, what I fear is not that they will find tyrants among their leaders but rather that they will find protectors.

I therefore believe that the kind of oppression that threatens democratic peoples is unlike any the world has seen before. Our contemporaries will find no image of it in their memories. I search in vain for an expression that exactly reproduces my idea of it and captures it fully. The old words "despotism" and "tyranny" will not do. The thing is new, hence I must try to define it, since I cannot give it a name.

I am trying to imagine what new feature despotism might have in today's world: I see an innumerable host of men, all alike and equal, endlessly hastening after petty and vulgar pleasures with which they fill their souls. Each of them, withdrawn into himself, is virtually a stranger to the fate of all the others. For him, his children and personal friends comprise the entire human race. As for the remainder of his fellow 
citizens, he lives alongside them but does not see them. He touches them but does not feel them. He exists only in himself and for himself, and if he still has a family, he no longer has a country.

Over these men stands an immense tutelary power, which assumes sole responsibility for securing their pleasure and watching over their fate. It is absolute, meticulous, regular, provident, and mild. It would resemble paternal authority if only its purpose were the same, namely, to prepare men for manhood. But on the contrary, it seeks only to keep them in childhood irrevocably. It likes citizens to rejoice, provided they only think of rejoicing. It works willingly for their happiness but wants to be the sole agent and only arbiter of that happiness. It provides for their security, foresees and takes care of their needs, facilitates their pleasures, manages their most important affairs, directs their industry, regulates their successions, and divides their inheritances. Why not relieve them entirely of the trouble of thinking and the difficulty of living?

Every day it thus makes man's use of his free will rarer and more futile. It circumscribes the action of the will more narrowly, and little by little robs each citizen of the use of his own faculties. Equality paved the way for all these things by preparing men to put up with them and even to look upon them as a boon.

The sovereign, after taking individuals one by one in his powerful hands and kneading them to his liking, reaches out to embrace society as a whole. Over it he spreads a fine mesh of uniform, minute, and complex rules, through which not even the most original minds and most vigorous souls can poke their heads above the crowd. He does not break men's wills but softens, bends, and guides them. He seldom forces anyone to act but consistently opposes action. He does not destroy things but prevents them from coming into being. Rather than tyrannize, he inhibits, represses, saps, stifles, and stultifies, and in the end he reduces each nation to nothing 
but a flock of timid and industrious animals, with the government as its shepherd.

I have always believed that this kind of servitude - the regulated, mild, peaceful servitude that I have just describedcould be combined more easily than one might imagine with some of the external forms of liberty, and that it would not be impossible for it to establish itself in the shadow of popular sovereignty itself. (II, 384-386, G817-819)

As I said, for many this is the dramatic climax to Volume Two and the whole book, the passage where Tocqueville gets his whale, or it gets him. It's worth noting however that he hardly says anything here that he hasn't said before; but when it comes to sustained theatrical flair and frisson, this passage surpasses even the disturbing description from Volume One of the modern omnipotent majority's attack on the soul of dissidents.

Interestingly, both passages make use of anthropomorphism to posit the new unnamable force in an imaginable body, even though Tocqueville says explicitly that this new mild despotism will most likely not be the intention or work of any one "master" or "sovereign," nor even of that which today we fumblingly label with names such as "Paris," "Washington," "Moscow," or "Downing Street." In other words, Hitler and Stalin were archaic throwbacks to the hard "sticks and stones" despotism of antiquity, especially Rome. ${ }^{70}$ Orwell recognized that much, which is why in 1984 he only has Big Brother exist as a poster, a menacing surveillance system, and of course a name. What he didn't choose to feature (had he read his Tocqueville?) was the new convenient soft-serve approach of truly modern headless despotism. This mistake, if that's what it is, was pointed out to him by one of his former Eton professors, Aldous Huxley, in a letter. ${ }^{71}$ Huxley's much earlier Brave New World (1932) is arguably closer to the totally automated despotism that Tocqueville had in mind.

But Tocqueville's story, like Melville's whale tale, does not end with this terrible dramatic encounter, and the actual conclusion to Democracy in America that comes about fifteen pages later is more subdued and practical minded. And it's a good thing too, because what Tocqueville presents as something scary, or at least highly objectionable, some people are simply not going to find scary. On the contrary, they're going to welcome 
it just like they welcome the new convenience store or Internet café opening up down the street. That Tocqueville secretly suspects the possibility of this undesired reaction ("Who's afraid of Trader Joe's?") may explain why he feels it necessary to ramp up the fear factor. Other contemporary readers raised on the gothic, the grotesque, and the fun of scaring themselves (and for whom the Cold War is already ancient history) may not ever get beyond the sci-fi frisson to ask themselves what they're supposed to think about this new... whatever it is, and more importantly what, if anything, they should do about it. Tocqueville, ever the content provider, has some suggestions though, and he doesn't leave us to make up our own minds until the very last sentence:

It is beyond the ability of nations today to prevent conditions within them from becoming equal, but it is within their power to decide whether equality will lead them into servitude or liberty, enlightenment or barbarism, prosperity or misery. (II, 402, G834)

The first claim about the inevitability of equality of social conditions everywhere is something we will return to later. For now, it's worth focusing on the second claim, "the Robert Frost moment" we could call it, which is that nations can choose one of two roads - the grassy road to democratic liberty or "the road to serfdom" as one reader of Tocqueville famously translated it with the pointed suggestion that to choose servitude would be to choose a return to the stony Middle Ages with its rigid caste system and low mobility. ${ }^{72}$

But Tocqueville knows that many people, harried democrats as well as nostalgic aristocrats, have a less dim view of those stable medieval times. That's why here, unlike at the end of Chapters Seven and Nine of Volume One where he thought he could play the schoolmaster and submit questions to the reader with the reasonable expectation of getting back the answers he wanted to hear, Tocqueville declares that there is a decision to be made but he does not formulate it explicitly as a question. Nor does he try any more shock and awe scare tactics, hectoring, or pleading. Although he did not have children of his own, he tries nevertheless to behave like a liberal father who wants to see his children, here his readers 
and by extension all his countrymen, grow up to be independent, creative adults and not remain children forever.

Therefore, he says one more time what he believes; namely (1) that equality and the democratic mores that develop out of that social state are not best thought of as categorically good or bad, (2) that through a combination of chance and choices democracy's specific functioning in actual circumstances now and in the future will be more or less free or oppressive, healthy or unhealthy, life-affirming or degrading, humanizing or dehumanizing. Tocqueville has spent nine hundred pages showing how democracy can or could go in many directions depending on the awareness and motives of the living actors, large and small, powerful and ordinary, who are involved in the process of government or simply living and working in civil society and making hundreds of conscious and unconscious decisions (votes) per day while going about their business. And he explains why, in the last analysis, he favors the more mature, legitimate passion for equality that spurs all men to wish for everyone to have the opportunity to be strong, free, and esteemed. This position may require him to sacrifice some types of grandeur and beauty, and accept a certain amount of vulgarity, monotony, mediocrity, and roughness, but it is, he believes, more just. He doesn't go so far as to say that he endorses this fraternal vision because it is God's will, only that it is God's preference. Secularists may even point out that he really didn't have to invoke God at all, just as he didn't have to say that greater equality in modern times is "a providential fact" instead of the outcome of political choices. Why? Because he has come to believe, without needing to be told, that the pursuit and consecration of liberty and justice for all is itself grand and beautiful.

\section{Q}

This is by no means an exhaustive account of Democracy in America, and my focus on what Tocqueville has to say about interpersonal relations in democratic lands has not been everyone's choice. Readers are encouraged to compare my Internet Age interpretation to other commentaries some of which will be discussed in the next chapter. In Part Three, I will return to Tocqueville's explicit and implicit policy recommendations for preserving democratic liberty and fending off democratic tyranny. 
Halfway through my Tocqueville courses I give students a midterm "20 Questions” exam to see how well they've understood and remembered what they've read. If you want to test yourself, before or after reading Democracy in America, here are the questions. Tocqueville's answers can be found in the chapter referenced after each question, and my own paraphrase of those answers can be found in the Appendix.

1. What are three of the original conditions that favored the spread of democracy among the Anglo-Saxon people in North America? (I, 1, ii)

2. When studying democracy in America, why is it necessary to examine what happens in individual states before considering the union as a whole? $(\mathrm{I}, 1, \mathrm{v})$

3. Why do the citizens of democratic lands often elect mediocre governors? (I, 2,v)

4. What are the real advantages derived by American society from democratic government? (I, 2, vi)

5. How does the majority in a democratic land become tyrannical? (I, 2, vii)

6. What moderates the tyranny of the majority in the United States? (I, 2, viii)

7. What are the main causes that tend to maintain a democratic republic in the United States? (I, 2, ix)

8. What are the main characteristics of the American philosophic method? (II, 1, i)

9. Why do Americans show more aptitude and taste for general ideas than the British? (II, 1, iii)

10. Why have Americans never been as enthusiastic as the French for general ideas in political matters? (II, 1, iv)

11. How does religion in America benefit and benefit from democratic tendencies? (II, 1, v)

12. Why is the study of Latin and Greek beneficial in democratic countries? $(\mathrm{I}, 1, \mathrm{xv})$ 
13. Why is theater so successful in democratic nations? (II, 1, xix)

14. Why do democratic nations display a more passionate and lasting love for equality than for freedom? (II, 2, i)

15. How do Americans combat the effects of individualism with free institutions? (II, 2, iv)

16. How do Americans counteract individualism by the doctrine of self-interest properly understood? (II, 2, viii)

17. Why are Americans so restless in the midst of their prosperity? (II, 2, xiii)

18. What is the influence of democracy on the family? (II, 3, viii)

19. How is it that Americans can be generally serious and yet sometimes behave recklessly? (II, 3, xv)

20. Why do democratic nations have a natural desire for peace while the armies within democratic nations naturally seek war? (II, 3, xxii)

\section{Notes}

33. Souvenirs is available in numerous English editions under the title Recollections, translated by Alexander Teixeira Mattos. L'Ancien régime et la revolution has been translated as The Old Regime and The Revolution by Stuart Gilbert (1955) and by Alan S. Kahan (2001) and as The Ancien Régime and the French Revolution by Arthur Goldhammer (2007) and as The Ancien Régime and the Revolution by Gerald Bevan (2008).

34. Claude Lefort's Préface to the Gallimard "Folio" edition of Souvenirs expresses such skepticism.

35. Paul de Man, "Autobiography as Defacement," in The Rhetoric of Romanticism (New York: Columbia University Press, 1984), 81.

36. The Random House College Dictionary (1976). For a discussion of Tocqueville's use of mores and manners and the eighteenth-century provenance from Montesquieu, John Adams, Adam Smith, and Edmund Burke, see the October 20, 1996, blog post of Jeff Weintraub, "Tocqueville on Mores," which includes this excerpt from a Tocqueville letter to his friend Corcelle (September 17, 1853) translated by Roger Boesche: "You say that institutions [which is what is usually meant by "laws" in, e.g., $D A$ ] are only half my 
subject. I go farther than you, and I say that they are not even half. You know my ideas well enough to know that I accord institutions only a secondary influence on the destiny of men. Would to God I believed more in the omnipotence of institutions! I would have more hope for our future, because by chance we might, someday, stumble onto the precious piece of paper that would contain the recipe for all wrongs, or on the man who knew the recipe. But, alas, there is no such thing, and I am quite convinced that political societies are not what their laws make them, but what sentiments, beliefs, ideas, habits of the heart, and the spirit of the men who form them, prepare them in advance to be, as well as what nature and education have made them" (Boesche, 294). In short, "habits of the heart" (borrowed for the title of Bellah et al.) count as much as or more than the laws of the land in Tocqueville's political sociology, and neither can do without the other. See <http://jeffweintraub.blogspot.fr/1996/10/tocqueville-on-mores.html>. Accessed May 20, 2012. The Tocqueville specialist Roger Boesche gained notoriety when he was signaled out by President Obama as his favorite professor at Occidental College. See Obama and other current Oxy students naming their favorite professors and classes: <http://www.youtube.com/ watch?v=D5T0FMFuFMg>.

37. The Goldhammer translation does not include Tocqueville's Introduction to the 12 th edition of 1848 , but the 1945 Knopf edition of $D A$ by Phillips Bradley and reissued by Random House/Vintage (1990) does include it (Volume One, xix-xxi) translated by Henry Reeve, Francis Bowen, and Bradley.

38. I have in mind former Modern Language Association president Gerald Graff, who is the author, with Cathy Birkenstein, of They Say/I Say: The Moves That Matter in Academic Writing (New York: Norton, 2007) — an instructive but overpriced guidebook for "clueless" students.

39. I am borrowing the list of modes of development presented chapter by chapter in Mary Lou Conlin's Patterns Plus: A Short Prose Reader with Argumentation, 6th edition (Boston: Houghton Mifflin, 1998).

40. For a discussion of Tocqueville's stylistic choices, see Franklin R. Ankersmit, "Tocqueville and The Sublimity of Democracy," The Tocqueville Review / La Revue Tocqueville XV:1 (1994): 193-215; reprinted in Tocqueville et l'esprit démocratique, ed. Laurence Guellec (Paris: Presses Sciences-Po, 2005), 167-201.

41. The authors of The Federalist do not claim that the national government they favor will be perfect or infallible, they claim it is better than all other alternatives and so language measuring comparative likelihood, as in these two sentences from Federalist \#3, is common and may have caught Tocqueville's attention: "But not only fewer just causes of war will be given by the national government, but it will also be more in their power to 
accommodate and settle them amicably. They will be more temperate and cool, and in that respect, as well as in others, will be more in capacity to act with circumspection than the offending State" (my emphasis).

42. $D A \mathrm{I}, 101$ : “[E]n Amérique, c'est la religion qui mène aux lumières; c'est l'observance des lois divines qui conduit l'homme à la liberté." See also DA II, 12: “C'est la religion qui a donné naissance aux sociétés anglo-américaines: il ne faut jamais l'oublier; aux Etats-Unis, la religion se confond donc avec toutes les habitudes nationales et tous les sentiments que la patrie fait naître; cela lui donne une force particulière.”

43. Religion is discussed in the following chapters: $D A \mathrm{I}, 1$, Chapters Two and Four; DA I, 2, Chapter Nine, especially pages 392-408; DA II, 1, Chapters One, Two, Five, Six, Seven, and Eight; DA II, 2, Chapters Two, Nine, Twelve, Fifteen, and Seventeen.

44. Without any supporting evidence, Tocqueville claims that religions in America have been able to restrain themselves from encroaching on the political order-perhaps a case of wishful thinking? See DA II, 12: “[E] n Amérique, la religion s'est, pour ainsi dire, posé elle-même ses limites; l'ordre religieux y est resté entièrement distinct de l'ordre politique, de telle sorte qu'on a pu changer facilement les lois anciennes sans ébranler les anciennes croyances."

45. At the end of II, 1,2, Tocqueville states categorically his personal reluctance to accept such a yoke: "Pour moi, quand je sens la main du pouvoir qui s'appesentit sur mon front, il m'importe peu de savoir qui m'opprime, et je ne suis pas mieux disposé à passer ma tête dans le joug, parce qu'un million de bras me le présentent" (II, 19). Tocqueville's grave concerns in these early chapters of Volume Two about the survival of intellectual liberty in democratic times are repeated most forcefully in the three very last chapters: another example of Tocqueville's stylistic penchant for symmetry and circularity.

46. G342. See DA I, 403: "L'incrédulité est un accident, la foi seule est l'état permanent de l'humanité.”

47. G503. See DA II, 31: "Pour moi, je doute que l'homme puisse jamais supporter à la fois une complète indépendance religieuse et une entière liberté politique; et je suis porté à penser que, s'il n'a pas de foi, il faut qu'il serve, et, s'il est libre, qu'il croie." Five short paragraphs later, Tocqueville sums up: "Religious peoples are therefore naturally strong precisely where democratic peoples are weak, which shows clearly how important it is that men retain their religion when they become equals" (G503-504).

48. Literally "unique thought" or "single thought" — an expression attributed to the French writer Ignacio Ramonet to criticize right-wing close-mindedness of the Margaret Thatcher variety ("There is no alternative"-TINA), but also 
applicable to the Leftist orthodoxies of Sartre and his followers criticized by Aron. See also Claude Hagège, Contre la pensée unique (Paris: Odile Jacob, 2012).

49. See DA I, 2, 7, 344-345: "L'empire moral de la majorité se fonde en partie sur cette idée, qu'il y a plus de lumières et de sagesse dans beaucoup d'hommes réunis que dans un seul, dans le nombre des législateurs que dans le choix. C'est la théorie de l'égalité appliquée aux intelligences.... L'idée du droit que possède la majorité, par ses lumières, de gouverner la société, a été apporté sur le sol des États-Unis par leurs premiers habitants... on la retrouve jusque dans les moindres habitudes de la vie.”

50. Tocqueville's claims here are similar to Emerson's famous pronouncement in his signature essay "Self-Reliance" (1841): "For nonconformity the world whips you with its displeasure"-and the whip is figurative lashing as Emerson goes on to explain: “... And therefore a man must know how to estimate a sour face. The by-standers look askance on him in the public street or in the friend's parlor." In the last sentence of this paragraph Emerson says it takes special powers, namely "the habit of magnanimity and religion" to withstand the "unintelligent brute force that lies at the bottom of society" (The Portable Emerson, 145). One can see how Emerson would share Tocqueville's aversion to l'esprit révolutionnaire given its strict need for party discipline and enforcement of ideological purity.

51. "Les hommes naissent et demeurent libres et égaux en droits" [Men are born and remain free and equal in rights], from The Declaration of the Rights of Man and of the Citizen (1789).

52. In aristocratic times, efficiency is not important and grand projects are embarked on-pyramids, castles, cathedrals, etc.-with little concern for deadlines and budgets. In his mock-serious Theory of the Leisure Class (1899), another witness of American mores, Thorstein Veblen (1857-1929) examined the value of the impractical and the uses of the useless among the new aristocracy that emerged during America's predatory "Gilded Age"-a phenomenon that Tocqueville did not live long enough to see but saw the potential for. On pyramids, one may recall Thoreau's typical demoland gibe in Chapter One of Walden: "As for the Pyramids, there is nothing to wonder at in them so much as the fact that so many men could be found degraded enough to spend their lives constructing a tomb for some ambitious booby, whom it would have been wiser and manlier to have drowned in the Nile, and then given his body to the dogs."

53. These two expressions were first used in the warning farewell addresses of the American presidents (and former army generals) George Washington and Dwight D. Eisenhower, respectively.

54. See, Montesquieu (1689-1755), Lettres persanes (1721), and Adam Ferguson (1723-1816), An Essay on the History of Civil Society (1767). 
55. See Jill Locke and Eileen Hunt Botting, eds., Feminist Interpretations of Alexis de Tocqueville (University Park, PA: Pennsylvania State University Press, 2009).

56. The French word éducation can mean actual schooling, but also often refers to general upbringing, socialization, conditioning - whether deliberate and programmed or unconscious and haphazard.

57. Tocqueville married an English woman, Mary Mottley, in 1835, and stayed "married with infidelities," but no children, all his life.

58. G696, DA II, 3, 10, 252: “On lui a appris d'avance ce qu'on attendait d'elle, et c'est d'elle-même et librement qu'elle se place sous le joug. Elle supporte courageusement sa condition nouvelle, parce qu'elle l'a choisie.”

59. DA II, 19, G493: "As for me, when I feel the hand of power weigh upon my brow, it scarcely matters who my oppressor is, and I am not more inclined to submit to the yoke because a million arms are prepared to place it around my neck." And yet ten pages later he can praise the "joug salutaire à l'intelligence" imposed by religions that thereby contribute to man's happiness and grandeur in this world (II, 30).

60. G700; DA II, 257: "Le rigorisme des Américains naît en partie de là. Ils considèrent le marriage comme un contrat souvent onéreux, mais dont cependant on est tenu à la rigueur d'exécuter toutes les clauses, parce qu'on a pu les connaître toutes à l'avance et qu'on a joui de la liberté entière de ne s'obliger à rien." In other words, the opportunity (whether taken or missed) to have "full disclosure"-kick the tires, look under the hood-places full responsibility on the contracting parties: caveat emptor.

61. DA II, 256: "La nature s'y dédommage en secret de la contrainte que les lois lui imposent" [Nature secretly exacts compensation for the constraints that laws impose on her, G699].

62. G702, DA II, 259-260: "Il n'y a rien de moins rêveur que les citoyens d'une démocratie, et l'on n'en voit guère qui veulent s'abandonner à ces contemplations oisives et solitaires qui précedent d'ordinaire et qui produisent les grandes agitations du coeur."

63. His brusque remarks here in Part Three of Volume Two are best read in conjunction with his earlier extensive observations about the "Literary Physiognomy of Democratic Centuries" (DA II, 1, 13) as well as the related thoughts in neighboring chapters about democratic poesis and craftsmanship (DA II, 1, 9-21). Tocqueville provides there an elaborate and more nuanced exposition of the tension between reverie and more goal-oriented imaginative dreaming. 
64. G705, II, 263: "Je pense que le mouvement social qui rapproche du même niveau le fils et le père, le serviteur et le maître, et, en general, l'inférieur et le supérieur, élève la femme et doit de plus en plus en faire l'égale de l'homme."

65. See the following chapter: "How Equality Naturally Divides the Americans into a Multitude of Small Private Societies."

66. See Judith Butler, Gender Trouble: Feminism and the Subversion of Identity (London: Routledge, 1990). See also Christopher Lasch, Women and the Common Life: Love, Marriage, and Feminism (New York: Norton, 1997).

67. My translation: "En Amérique, une jeune fille entreprend, seule et sans crainte, un long voyage" (II, 266). Jeune fille in French can mean young girl, although petite fille would be more common. Jeune fille is most often used to refer to a relatively young (unmarried) woman who is addressed as Mademoiselle. All the published translations of this sentence that I consulted are a bit off. The Goldhammer translation, for example, turns une jeune fille into Red Riding Hoods who decide to go Greyhound: "In America, girls take long trips by themselves, without fear" (707).

68. G708, II, 266: “Pour moi, je n'hésiterai pas à le dire: quoique aux Etats-Unis la femme ne sorte guère du cercle domestique, et qu'elle y soit, à certains égards, fort dépendante, nulle part sa position ne m’a semblé plus haute; et si, maintenant que j'approche de la fin de ce livre, où j'ai montré tant de choses considérables faites par les Américains, on me demandait à quoi je pense qu'il faille principalement attribuer la prospérité singulière et la force croisssante de ce peuple, je répondrais que c'est à la supériorité de ses femmes.”

69. If Tocqueville is less sensitive to these ironies when it comes to gender politics, his vision is more acute when considering the American government's harsh treatment of Indians: “The Spaniards, despite acts of unparalleled monstrousness that left them indelibly covered with shame, were unable to exterminate the Indian race or even prevent the Indians from sharing their rights. The Americans of the United States achieved both results with marvelous ease, quietly, legally, philanthropically, without bloodshed, without violating a single one of the great principles of morality in the eyes of the world. To destroy human beings with greater respect for the laws of humanity would be impossible" (I, 452-453, G391).

70. For a definition of the traditional despot, see Sheldon S. Wolin's description in his Tocqueville book: "The despot gathered all the power to himself; would not tolerate rivals; eliminated political life; ruled by personal whim; lived extravagantly while demoralizing economic life; and, as Montesquieu emphasized, used cruelty to create a climate of fear that paralyzed opposition and stifled cultural creativity. These conceptions were all inconceivable without the dominating figure of the despot himself. The state of society was a projection of him. Everything flowed back to him; everything flowed from him. Despotism as the abnormality of power." Tocqueville Between Two Worlds: 
The Making of a Political and Theoretical Life (Princeton: Princeton University Press, 2001), 340.

71. This letter to a former pupil, dated October 21, 1949, is included in the Harper Perennial edition of Brave New World and Brave New World Revisited (1958). In his Introduction to a 2003 reprint, Christopher Hitchens discusses the letter and the Orwell-Huxley, student-teacher relation. The letter and Orwell and Huxley's conceptions of totalitarian states will be returned to in a later chapter, "Restore Previous Session."

72. See F. A. Hayek, The Road to Serfdom, ed. Bruce Caldwell (Chicago: University of Chicago Press, 2007 [1944]). Aldous Huxley, it seems, agreed: "The impersonal forces of over-population and over-organization, and the social engineers who are trying to direct these forces, are pushing us in the direction of a new medieval system." Brave New World Revisited, 28. 
Chapter 2

\section{Tocqueville's Commentators}

\section{Why read Tocqueville today?}

The amount of secondary literature on Tocqueville does not equal the mountains of material devoted to many older canonical authors or even to some of his contemporaries such as Emerson and Marx. It is however a substantial body of work, perhaps two hundred books and two thousand articles. $^{73}$ A large portion of the total, maybe a fifth or a quarter, was produced within the last twenty-five years; i.e., during the post-Cold War era that I'm calling the Internet Age. One might have expected interest in Tocqueville to fall off during this period if it's true that his popularity after World War II was linked to the development of "American Studies" as an interdisciplinary department or program (attractive to returning GIs and other patriots) within many colleges and universities, and to his usefulness to the Free World as a champion of liberty in the fight against Communism. ${ }^{74}$ If after the 1989-1991 dissolution of Eastern European governments Communism was mostly dead, and if the humanistic American academy was dying, being killed off (with interdisciplinary studies being a main target), ${ }^{75}$ or repurposed (as exclusively preprofessional vocational schools, sports camps, wellness centers, or retirement community annexes), who could possibly be interested in reading Tocqueville? Besides, wasn't Tocqueville just plain wrong about equality of social conditions being the distinctive feature of American society? And not only wrong about today's America of extreme inequality ${ }^{76}$ but wrong about nearly every decade in American history going back to the 1830s. ${ }^{77}$ Wasn't he only able to call America egalitarian because he was using monarchical France as a skewed yardstick and because he mostly bracketed the case of blacks, Indians, and women and underestimated 
the negative impact on equality of the advancing industrial revolution, the market revolution (Sellers ${ }^{78}$ ), and the communication and transportation revolution (Howe ${ }^{79}$ )? If so, how could people think it worth their while to "rediscover" Tocqueville $?^{80}$ Surely the French press's habit of marking important anniversaries (10th, 20th, 25th, 30th, 50th, 100th, 200th, etc.) with articles, special issues, and other publications is not an adequate explanation, especially in the case of an author that most French intellectuals preferred to ignore for over a century, and also since many fairly recent publications in America and France appeared before the Tocqueville bicentenary in 2005.

Well, first of all, it is a well-known fact that peace and the "peace dividend" did not come through with the end of the Cold War. And the celebration of the West's victory over Communism, of "freedom" over "serfdom," eventually died down, along with the enthusiasm for Francis Fukuyama's The End of History and the Last Man (1992), and was rather quickly moved off the front page by Bill and Monica, O.J., and then "September 11."

But before 9/11 changed everything, many who were worried about finding a new raison d'être for U.S. foreign policy and the militaryindustrial complex in the post-Communist era (and thus keeping their jobs and keeping Americans fearful and docile) looked to Samuel P. Huntington's "The Clash of Civilizations" $(1992,1996)$ for a new global ideological conflict to replace the old Cold War. The flap created in North America and Europe by and around the books of Fukuyama and Huntington ("It's over!" / "No, it's not over!") arguably brought more readers to Tocqueville- he who had wondered if democracy in America would last, if it could take hold in France, if the Old Regime was dead or alive, and which parts of it were worth praising and preserving in order to save democracy from itself. Tocqueville's stock was also boosted by the obvious fact that there were plenty of Eastern European Communists living on in various guises after Communism, and some of these people who had only ever thought of "democracy" and "America" as a dream or nightmare may have decided to try and know more, and there was old Tocqueville ready to offer his help to those who wanted to investigate, weigh, judge, or tutor democracy as he recommended we do ("instruire la démocratie"). In other words, world events between 1989 and 2001 got 
more people in America, France, and other places to take a closer look at themselves and ask about what Martha Nussbaum has called "the clash within," and for this many have found reading Tocqueville helpful. ${ }^{82}$

In addition to recalling these recent events that I'm arguing had the unintended consequence of reviving interest in older theories about democracy such as Tocqueville's, it should be said that the fact of American inequality (as measured by income, education, health, housing, profession, etc.... or by the less easily quantifiable notions of rights and mores), whether in 2035, 1935 or 1835, does not disqualify the interest one might have in the theoretical point Tocqueville is making; namely that equality of social conditions among a people is a necessary though not a sufficient condition for democracy and a democratic way of life. If a large income gap, education gap, health and health care gap, mobility gap, or mores gap makes democracy unworkable, this is something that both democracy's friends and enemies ought to keep in mind (for different reasons), and Tocqueville can help you do that. Want to kill off democracy and replace it with a corporate, military, or mafia model? Read Tocqueville. Want to keep democracy from being taken over by or merging with corporations or the mafia or the military? Read Tocqueville. Want to keep democracy from committing suicide? Read Tocqueville. Want to push democracy over the edge and its people too? Read Tocqueville. If Tocqueville's writings are not exactly a how-to manual, neither are they simply "academic." In the right hands, his writings are a super "apps" store, no matter whether you're interested in genuine ordinary democracy, covert or overt oligarchy (also known as "republicanism"), or direct dictatorship.

\section{A Taxonomy of Tocqueville's Commentators}

Tocqueville's commentators can be grouped and talked about in many ways. One, obviously, is by time period. Commentators from the pre1989 era can be divided into four groups. In the first are Tocqueville's contemporaries: the first English translator Henry Reeve, important early reviewers such as Sainte-Beuve and John Stuart Mill, and the author of introductions to the first American editions of Democracy in America, John C. Spencer. ${ }^{83}$ A second scholarly, pre-World War II 
group takes shape around the time of the centenary with the founding/ framing work of J. P. Mayer, George W. Pierson, and Phillips Bradley. ${ }^{84}$ A third high Cold War group takes shape with a new translation (later often criticized) by George Lawrence, edited by J. P. Mayer (1966), and includes the work of David Riesman, Max Lerner, Martin Lipset, and Raymond Aron. ${ }^{85}$ The joint French-American founding of The Tocqueville Review / La Revue Tocqueville in 1979 constitutes the late Cold War consolidation of Tocqueville studies as an international field of scholarly research. Important figures within this fourth group include François Bourricaud, André Jardin, François Furet, Jean-Claude Lamberti, Claude Lefort, Pierre Manent, Françoise Mélonio, Robert Nisbet, and James T. Schleifer. ${ }^{86}$ This journal celebrated its twenty-fifth anniversary just in time for the bicentenary with a special "best of" anthology, Tocqueville et l'esprit de la démocratie (Presses de Sciences Po, 2005).

In the post-1989 era, there are many commentators who are publishing research on Tocqueville for their own reasons. Some are long-term projects that may have been started before the events of 1989-1991 and have little direct connection to them. Two examples would be Robert Putnam's Bowling Alone (1995, 2000) and Habits of the Heart: Individualism and Commitment in American Life (1985, 1996, 2008) by Robert N. Bellah, Richard Madsen, William M. Sullivan, Ann Swidler, and Steven M. Tipton. There are others who may have had their interest in Tocqueville spurred on by world events, by personal events, and/or by the work of other Tocqueville scholars that appeared in the 1970s and 80s (Antoine, Heimonet, Janara, Welch, Wolin). And although it may not be as strong a habit within American academia, the role played by anniversaries in France-a centralized country long obsessed by both math and history - is not to be underestimated.

A birth year, death year, or year of publication is not just a handy attention-getting device for newspapers and magazines, but an important "magic marker" as it were that can drive the organization of conferences and seminars, and influence the selection of the authors and ideas to be studied in a given year in all French secondary schools and universities. They can also influence the syllabi within selective junior college programs known as "prépas" as well as the list of items to be thoroughly studied in a dense program of cram courses prior to taking one of France's 
concours, the annual competitive exams that grant the winners lifetime employment as a civil servant (fonctionnaire) within France's National Education system. ${ }^{87}$ Publishers know that the pool of students who compete for these coveted jobs are a captive audience. In many ways they resemble the eager, docile, anxious, pragmatic, and self-interested demoland citizens Tocqueville describes in DA II, 1, and elsewhere. In other words, ideal consumers (numerous, predictable, and ready to spend), and for publishers this means being able to take risks on items that otherwise would have a harder time finding an audience. Consequently, there are professors who are going to hitch their wagon to a star and profit from the momentum, buzz, and sales that anniversaries routinely generate. There may be nothing wrong with this random and forced allocation of one's time and attention based on concours and calendar-counting; who knows? It does seem to focus the mind, and it has the added benefit of regularly yanking the lazy narcissist in each of us away from the contemporary prose streaming through our consciousness by exposing us to thinkers and thoughts from the so-called past. Is that any worse (or better) than having one's attention decided by Google, some website's "most e-mailed" list, or one's friends or thesis director? That's a real question.

At any rate, this cultural practice of the French, which goes on elsewhere in somewhat milder forms, needs to be factored in if one wants to explain why all of a sudden around Tocqueville's bicentenary there are three new translations of Democracy in America (2000, 2003, 2004), four new Tocqueville biographies (De Robien 2000; Benoît 2005; Brogan 2006; Jaume 2008), new scholarly general assessments (Audier 2004; Boesche 2007; Boudon 2005), new essay anthologies (The Tocqueville Review / La Revue Tocqueville 2005; The Cambridge Companion to Tocqueville 2006), new study manuals (Amiel 2002; Dubois 2004; Frioux 2002; Lafitte 2004; Guineret 2007; Ziccardi 2011), and many new single volumes and reprints of various selected shorter pieces taken from Tocqueville's Oeuvres Complètes, which of course are in the public domain. ${ }^{88}$ And that's not counting what's going on in other media on or around 2005, or what's been produced after 2008 (Craiutu and Jennings, Damrosch, Elster, Epstein, Kaledin, Locke and Botting, Mansfield, Rahe, Zunz and Goldhammer) or the mute inglorious Miltons who assign and 
teach Tocqueville in undergraduate or graduate courses without leaving any record.

A second way to organize what's been written by or about a famous author is by genre or type. In the case of Tocqueville these would include the following: allusion, anthology, article (scholarly, semischolarly [e.g., NYRB], mass market), biography, book review, didactic manual, edition, editor's introduction, encyclopedia entry, epigraph, essay, the Internet (blogs, online journals, forums, conferences, editions, bibliographies, course materials, etc.), mention, monograph, multiauthor study, paraphrase, quotation (short, medium, long), reader, reception history, review essay, single-work or single-topic study, translation, translator's note. One might also include various forms of "following in Tocqueville's footsteps" whether conceived as homage, parody, pastiche, or poems. ${ }^{89}$

Another genre, perhaps the most frequently used today, might be called Tocqueville sauce, a tricky mixture of name-dropping allusion and paraphrase that can either carry or bury thinking. An example occurs in the Elizabeth Badinter profile referred to above when the author Jane Kramer quotes Badinter's idea of what separates her from "most other feminists":

"I never saw myself as victimized or stifled; I never saw all men as oppressors. That one fact-the fact that I didn't suffer-has shaped my point of view. I know that I grew up in a very privileged world, socially, but like Tocqueville, talking about the eighteenth century, I think the most privileged classes are often the ones least tolerant of inequality. I never expected inequality. I was under no pressure to expect it. I had nothing to revolt against." (50, emphasis added)

Similar to epigraph, but less cold and static, Tocqueville sauce is a direct (mention) or indirect (allusion) reference to the great man smoothly inserted into a sentence that creates various effects (not necessarily all intended). Badinter's remark is a typical example of softly aligning the tutor-speaker's thoughts with those of a (better) known and (more) accepted authority.

I have never come across a willfully antagonistic lead-in or aside such as, "And as Tocqueville wrote, in words that are as false today as 
when they were written..." And yet writers and speakers who sympathetically apply Tocqueville sauce probably underestimate how much they may annoy the reader and provoke opposition. With writers like Tocqueville who are attracted to paradox and whose thoughts on paper are complex open networks, there is a fairly high risk of someone contesting whether the speaker's claim is really supported by the authority figure or specially selected quotation, when there is one. In this case, I would say that Badinter's claim may be true within a stable aristocratic society; i.e., when "talking about the eighteenth century," for example. It is the basis of the "Christmas spirit" (also known as the "Gospel of Wealth" and "giving something back to the community") that the most privileged can indulge in the easiest "to aid its servants and assuage their miseries" (DA II, 2, 20, 202, G652). But in a democracy such willingness becomes rarer and, frankly, less desired (because considered patronizing), and in its place there arises from different quarters a firm demand for social justice (as fairness) that replaces charity (or at least competes with it)..$^{90}$ Therefore the least tolerant of inequality (and most strongly in favor of "redistributive justice," in part because they're likely to benefit) tend to be those in the low- to middle-income range, not the most privileged. And so it is very important to specify what century and what type of regime one is talking about, as well as other particulars of its history, because, as Tocqueville notes, beliefs and behaviors vary significantly at different times and places even within the same "state." ${ }^{11}$ My point is that Tocqueville sauce, though potent, can cause indigestion by obscuring or contradicting the point of the person who decides to apply it.

The writings on Tocqueville can also be grouped by language. Up until now, more has been written about Tocqueville in English than in French, though this might change during this century depending on who cares most about Tocqueville and democracy and in what language they express that care. Some authors have had their work on Tocqueville translated into other languages, sometimes more than one. The major works of Tocqueville and several of the most intriguing essays (on poverty and colonialism, for example) exist in many languages. The Bradley/Knopf bibliography lists editions of Democracy in America in Danish, German, Hungarian, Italian, Russian, Serbian, Spanish, and Swedish. A casual glance at the websites of online booksellers outside the U.S. reveals that 
translations also exist in Japanese and Chinese. One can also find recent work on Tocqueville published in German, Spanish, and especially Italian. ${ }^{92}$ I regret that I can only read French and English competently, but it pleases me to know that Tocqueville is being read, hopefully well, in those other linguistic and cultural contexts.

To round out this taxonomy, we can list three final arrangements according to which what has been written about Tocqueville could be organized: audience (students, scholars, ordinary readers), attitude (very sympathetic, generally admiring, critical, hostile, complaisant, neutral), and purpose (advocate, amuse, doubt, entertain, inform, instruct, judge, persuade, question, weigh, wonder, etc.) - and of course a single text could have multiple aims and effects.

\section{How to Read Tocqueville / How Not to Read Tocqueville}

Of all the writings on Tocqueville during the Internet age that I have been able to put my hands on and get to know, I have selected eight texts that can serve as examples of how to read and how not to read Tocqueville. By reading Tocqueville, I mean an engagement with the complexities of his text that at least approximates Tocqueville's labor to read and understand the complexities of the institutions and mours of America and France. The four ways not to read Tocqueville can be summarized as follows. Instead of reading the text, (1) talk about how it was made; (2) talk about how it has been read by others; (3) talk about something else and use large helpings of Tocqueville sauce (i.e., allusion and quotation) to claim that his text is a perfect mirror, illustration, confirmation, prefiguration, etc., of that other thing; (4) talk about something else and claim that Tocqueville is of little or no help understanding that other thing and therefore not worth reading.

I know that reading is not everyone's preferred learning style, nor perhaps should it be. And because I am a teacher and not a salesman pushing product, and therefore open to the idea that there is something to be learned from mistakes and small achievements as well as from grand accomplishments, I have chosen four works that I consider to be flawed but interesting, and four others that I consider interesting but flawed. ${ }^{93}$ In each group of four, there are two texts in English and two in French. 
To my knowledge, none of the French texts have been translated into English and vice versa. The authors of the texts in the first group are Leo Damrosch, Claire Le Strat and Willy Pelletier, Paul A. Rahe, and Emmanuel Todd. The authors of the texts in the second group are Agnès Antoine, Jon Elster, Jean-Michel Heimonet, and Sheldon S. Wolin. To me, the first four exemplify different ways of how not to read Tocqueville; the second four are examples of how to read Tocqueville.

\section{Leo Damrosch, Tocqueville's Discovery of America (2010, 277 pages)}

One way not to read Democracy in America is to talk about how it was made. This is what Leo Damrosch decides to do, though I am not claiming that evasion was his motive nor that he entirely avoids talking about the text. The book is a remake of the récit de voyage told by George W. Pierson in 1938 (Tocqueville and Beaumont in America) and is not to be confused with James T. Schleifer's The Making of Tocqueville's "Democracy in America" (1980), for which it is the backstory. There is certainly nothing wrong with doing an original retelling of a good story.

Damrosch's book was reviewed by Martin Rogoff in the American Journal of Legal History and by James Wood in the New Yorker. ${ }^{94}$ After asking the unavoidable question, Why another book on Tocqueville?, Rogoff describes this new offering: "In Tocqueville's Discovery of America, Leo Damrosch describes aspects of Tocqueville's experience in America that give us a deeper appreciation of how Tocqueville came to the ideas and insights which he so eloquently expressed in Democracy in America. Damrosch focuses narrowly on Tocqueville's American experience itself." Rogoff then makes deft use of a quotation from Isaiah Berlin on the strenuous challenge of becoming good at political judgment (because it requires paying attention to so many different constantly changing things at the same time) and returns to it in his conclusion to say that Tocqueville comes close to the ideal described by Berlin and that "Damrosch's book enables the reader to participate in that experience." But does it enable reader participation? How much and what kind? If Tocqueville's discovery of America is a set of daily events that only really exist thanks to the organizing, meaning-making textual event of his diary and other writings on the subject, then by focusing narrowly on Tocqueville's American 
experience itself, Damrosch may be underestimating the importance of Tocqueville's voyage of the mind (if the metaphor is not abusive) without which there would probably have been no discovery of America because his political judgment (which occurs in language) would not have been exercised. How much of that kind of exercise does the reader get from this book? Damrosch is a good storyteller and a knowledgeable tour guide (pausing regularly to tie in stops on the journey with a plot-thickening quotation from Tocqueville or some other author), but it seems legitimate to ask if the text's desire for clarity and narrative pace doesn't impede exercising one's mind over a set of discoveries that of necessity, par la force des choses as the French say, can seem obscure (to those whose eyes are not yet adjusted) and therefore cause stumbling.

James Wood has similar reservations and chides his Harvard colleague for giving a too partial (in all senses) account of Tocqueville's discovery - too "scintillating," too smooth and one-sided to capture Tocqueville's "unadorned intellectual charm" and his constant "tacking from anxiety to optimism and back again." I share Wood's feeling that "Damrosch contagiously enjoys himself" (106) as he retells the talehe could be brought in as a consultant on the screenplay of a rollicking "buddy" road trip movie adaptation-but is joy or enjoyment really what's most appropriate given the subject matter?

Reading Damrosch, one is reminded that transatlantic travel in those days was calculated in days or even months, roads were often terrible, and river travel could be hazardous. It is a wonder, given all the adversity, that in 1831 two twenty-something French aristocrats, who could have just continued slouching toward whatever while living off the land (labored by others in their service), would choose instead to go off to America for nine months like a couple of graduate students doing field research, get back alive, and write dissertations that people actually paid money to read instead of the other way around. And it is interesting to learn about Tocqueville's reactions to what he witnessed, such as the solemn Fourth of July celebration in Albany, and about the informants who shared their views in response to Tocqueville's many questions. ${ }^{95}$ But we are not enabled to learn as much about Tocqueville's struggle to make sense of it all, because that's not the story Damrosch chose to tell. Over all, the book is informative and enjoyable, simply not all that probing or 
doubting, perhaps because really there is no argument. The book's bland last sentence is a clear sign that something is just not right: "Tocqueville's issues are still with us and still unresolved." You can't argue with that.

\section{Claire Le Strat and Willy Pelletier, La Canonisation libérale de Tocqueville (2006, 288 pages)}

Back at the pre-dawn of the Internet age, so-called reception theory and reception histories were for a time one of the more popular forms of literary criticism that had cropped up in the wake of 1950s formalist criticism and its radicalization in America as "theory" in the '70s and '80s. These metadiscourses about how reading was being performed within a given "interpretive community" were no doubt a welcome change of pace for those fatigued or annoyed by the "reading for rhetoric" they'd been taught in graduate school. ${ }^{96}$ The latter activity could be carried on by those teaching "comp," they figured, because they were no longer interested in "the meaning of meaning." They wanted to talk about politics and history.

In France's universities things didn't evolve that way because formalist criticism (especially the twin scholastic exercises commentaire de texte and dissertation) continued to play a dominant role within the concours system. And formalism's dominance extended into all the earlier school years as well going back to about age twelve since the language curricula are all designed in view of some future sorting and selecting procedure, and those two exercises along with math testing have been the standard French tools for over a hundred years. Therefore reception theory, generally understood to be a German-American import presented in the work of S. Fish, W. Iser, and H. R. Jauss, didn't catch on in French language departments. However it did find a home in sociology departments, notably in the work of Pierre Bourdieu (1930-2002) and his continuators who were interested in extending the Weberian analyses of the circulation, conservation, and transmission of power and prestige among the members of certain professionalized groups. ${ }^{97}$

La Canonisation libérale de Tocqueville by Claire Le Strat and Willy Pelletier is a late application of such techniques to the world of French Tocqueville enthusiasts of the twentieth century. They claim that this 
group is very homogeneous and dominated by a doxa such that the whole community (if that's the right word) constitutes what Bourdieu and others called a "habitus." For us laypeople, the authors choose to convey the idea metaphorically by likening Tocqueville studies to the Catholic Church, where Tocqueville would be a sanctified prophet who is worshipped by his faithful followers, the pope or "papa" among them being Raymond Aron (1905-1983). The book offers a detailed account of the genesis and genealogy of this "liberal" "church" founded by Aron, Tocqueville, and their sacred texts that together form a sort of holy trinity.

This "canonisation" story deserves to be translated into English and integrated within a Western history of ideas, and the history of the history of those ideas of course. It would be of interest to Tocqueville scholars since it provides the most detailed account of "Tocqueville and the French” since Françoise Mélonio's study from 1993. And since Tocqueville was French (wasn't he?), it seems worth keeping up to date on the reception history of his writings in France, or a certain France at any rate. It would also be of interest to anyone interested in the Cold War since the book focuses mainly on the polarized French academic milieu between 1955 (the year Aron published L'Opium des intellectuals, which formalizes the battle lines between Sartriens and Aroniens) and 1993, one could say, since Mélonio's reception history closes out the Cold War period with a last paragraph that tries to bring all parties to the peace table for a negotiated truce:

Tocqueville's work thus has been far more than a link in the historical chain of liberalism after Montesquieu and Constant and before modern democratic liberalism. The word liberal is only attractive in its vagueness. One cannot be simply a liberal. One can be an authoritarian liberal, a conservative liberal, a monarchist liberal, a republican liberal, a democratic liberal, a wise old liberal, a "new kind of liberal" like Tocqueville, or even under the Third Republic, "liberalish" or "liberawful." There are liberal practices, liberal sensibilities, liberals who were on the Left and on the Right, and sometimes, with the help of age, both in succession-but there is no French liberalism. The lineage in which we place Tocqueville's work is less important to us than its exoticism. An aristocrat by 
instinct and a democrat by reason, at the crossroads of French and American democratic cultures, Tocqueville has been the repressed side of democratic tradition. ${ }^{98}$

I think Mélonio is right when she says that Tocqueville is a figure of the repressed and that the word liberal is only attractive in its vagueness. But for anyone who seeks understanding, that vagueness soon becomes off-putting, and one realizes the only language users still attracted to the term are ideologues who seek to bash their enemies with it. In America those would be the "tax and spend liberals" vilified by conservatives, and in France the pro-business cult of "néo-libéralisme" denounced by the anticapitaliste Left. That liberal means "left" in America and "right" in Great Britain goes unexplained by Le Strat and Pelletier. ${ }^{99}$ Therefore, it's not surprising, given their choice of title and their view of liberalism as a dogma instead of a possible challenge to dogmas and rigidity, the authors cannot bring themselves to quote, much less follow, Mélonio's nuanced reading of the term liberal. For them, her closing remarks can only be another one of the clever ruses by which the Tocqueville church enforces obedience and closes off dissent. When convenient, a clique can always deny it's a clique to those outside the clique. School? What school? What doxa? What are you talking about?

In 1993, Mélonio is saying, "Look, it's over, or it should be over, so let's stop using Tocqueville as a sword and shield, and reinvent some esprit communal with which to treat our common interests in common-i.e., learning from reading Tocqueville in an open, collegial way." Le Strat and Pelletier will have none of that mushy appeasement talk. For them it's not over, and there's not a shadow of a doubt that Tocqueville studies as practiced in France (and presumably in the United States, though they don't bother citing any work on Tocqueville from the last ten years) is part of an "ongoing conservative modernization" as their backer Bernard Lacroix puts it in an explanation of the raison d'etre of the collection this book belongs to and that he directs entitled La Politique au scalpel"[Politics under the scalpel]. The upshot is a decisive rejection of Tocqueville and Tocqueville studies in the history it tells.

One can't help feeling, however, that the authors are cutting off their nose to spite their face with their strident tone, the constant suspicion, and especially the decision to include so few actual sentences from 
Tocqueville in their book; whereas they cut and paste passages from Aron and other commentators with a vengeance. Once they'd put their case to the reader (resolved: there is a right-wing Tocqueville consensus in France that has locked in certain interpretations of his writings to the exclusion of all others; here's how it got started; here's how it works; here's why it's harmful, etc.), why didn't they just set it aside and go on to develop their own alternative vision of Tocqueville, or, if they like, argue why reading Tocqueville is a lot less valuable in today's world than, say, reading Mill or Marx or Mitterrand? What was stopping them from cutting open that closed "horizon of meaning" they claim hangs over Tocqueville studies by writing their own story? Instead they sign off with a timid backward-looking hope:

Maybe the investigation will have been worth it, if we get out of it [presumably, the closed horizon of meaning mentioned at the end of the preceding paragraph] in the strong sense conveyed in Balzac's phrase, "disabused about social grandeurs." [“désabusé sur les grandeurs sociales"] (272, my translation)

By going on at length about an interpretive community whose vision they clearly disagree with, yet in the end offering no alternative interpretation of their own, the authors wind up lending even more prestige to their opponent (since bad publicity still counts as publicity); and no one will know whether their own vision was strong, weak, or somewhere in between, because they left the field without writing it up.

\section{Paul A. Rahe, Soft Despotism, Democracy's Drift: Montesquieu, Rousseau, Tocqueville, and the Modern Prospect (2009, 374 pages)}

What does Paul A. Rahe want? What's his dream job? What's his dream for America for the twenty-first century? Is it a dream that takes into account the inalienable rights of all men, women, and children - the tall and the small-to life, liberty, and the pursuit of happiness? What would be, say, twelve measurable, achievable, relevant actions that he would like to see taken-and by whom? - that would move the country closer to his vision of what America could and ought to be? And what arguments could he offer in favor of his top twelve to someone who might possibly 
disagree with one or more of his choices and argue instead for a different list of policy initiatives?

I'm leading off with these questions to make up for the fact that Rahe asks so few. In 280 pages of text plus another seventy pages of detailed footnotes, Rahe uses the question mark only twice $(258,310 \mathrm{n} 53)$. The only other question marks that appear in the book occur in some quotations and in the titles of other people's work. This aversion to the interrogative mood-if that's what it is - is unusual in a scholarly publication, which is generally presumed to be the write-up of a research project built around a problem (and set of related questions) that the author wants to solve. ${ }^{100}$ Rahe's Introduction, however, does not leave the reader guessing about what problem he wants to solve and how. After two pages devoted to recalling for the reader a selection of historical events and related publications that deal with the collapse of Communism and some symptoms of ill health in the West, Rahe writes, "There is something altogether odd and not a little unsettling about these developments, for they leave us wondering where to turn" (xiii). Restated as questions, Rahe is asking: If Communism just died, and Communism was the West's arch enemy, then why is the West not feeling all that happy and healthy? And what should "we" (Westerners?) do now? With whom? Why? So without coming right out and saying so, Rahe's book is a guide for the perplexed, a group in which he would seem to include himself-or at least a former "blind" version of himself before everything became clear to him. He offers a solution to our problem at the bottom of the next page:

If, then, we wish to understand whither we are tending, we would be well-advised to reacquaint ourselves with a forgotten form of political science and to read with care Montesquieu and then those, such as Rousseau and Tocqueville, who closely followed his lead and expanded in crucial regards upon what he had to say. This is, however, easier said than done. (xiv-xv)

It should be noted that when Professor Rahe says "read with care" and "easier said than done" and throws in gentlemanly archaisms like "whither we are tending" and "crucial regards," he is speaking the language of 
anyone who has ever come within a hundred miles of a certain private university located in New Haven, Connecticut.

The reason such reading won't be easy, Rahe informs us, is that Montesquieu "lived in an age of censorship, and he composed his works in conformity with unwritten rules of discretion, intimating that which could not with profit be openly said" (xv). So Montesquieu was a wily practitioner of the arts of indirection, an ironist to put it bluntly; and Rahe proposes that we read carefully and pay special attention to how he was read by Rousseau and Tocqueville, i.e., that we read readers reading. This "intellectual" challenge, which, Rahe adds, "is also literary" and "unavoidably historical" corresponds closely to what was for many "in a time now largely forgotten and unfamiliar" (xv) the bread and butter of "a free and ordered space": the utopian paradise known as Comparative Literature.

The promise Rahe makes us, his readers, is that if we take his advice and "undertake a journey into the past" (xv) to the days of the great teacher Montesquieu, an "archeological" task Rahe calls it (winking at Michel Foucault?), and then move forward to the time of his disciples Rousseau and Tocqueville, and if we read carefully at each step along the way, then we can experience a "liberation" (xv) from the unsettling developments in recent times and "recover from the profound sense of malaise to which we are now prone" (xvii).

And what is the malaise, the new "mal du siècle," for which Rahe offers us a cure? It is "Soft Despotism," an unhealthy condition first diagnosed among his French compatriots by the brilliant independent scholar Tocqueville and then re-diagnosed by Rahe (with Tocqueville's assistance) in full-blown form in contemporary France (see Chapter Three, "The French Disease") and then again in a perhaps treatable form in the United States (see Chapter Four, "Despotism of Administrators," and "Conclusion"). So we (the French, Americans, and lots of others in the European Union, Canada, Australia, and New Zealand!) are sick. But if we virtuously take individual responsibility as Rahe recommends (280), such as by reading carefully, we can cure ourselves and be well again. That's a stern yet ultimately hopeful message, but as with other recommendations about eating right, exercise, etc., the prescription is "easier said than done." 
One would expect Rahe to lead by example and be a careful reader. But is he? I leave it to others to decide what they think about his treatment of Pascal, Montesquieu, and Rousseau, but when it comes to Tocqueville, my answer is No. One symptom is that his text never doubts or questions anything that Tocqueville ever said or did. For him, it would seem, Tocqueville is an infallible prophet, his texts an oracle, a set of revelations that speak for themselves and thus need (must!) only be cited, accepted, and applied to modern times. Tocqueville's oeuvre is Rahe's bible, and its literal truth goes unquestioned by him. Again, this is unusual coming from a university history professor. Couldn't Tocqueville, like his teacher Montesquieu, also have been forced to write in a multilayered, rhetorically complex, nonliteral way at times? Was his age not also subject to tough censorship laws, the clunky weight of inflexible Aristotelian logic, and peer pressure? Were not freedom of speech and freedom of association severely limited and under constant threat of further erosion throughout his lifetime? And didn't Tocqueville have his weaknesses and blind spots like anyone else? If the answers to these questions are Yes, then one would expect Rahe to be more careful, i.e., more circumspect and resistant, when quoting and discussing Tocqueville.

Consider, for example, the long passage (quoted and discussed a bit hastily in my last chapter) where Tocqueville offers his vision of the "new features despotism might have in today's world” (G818). Given his title and the whole drift, to borrow a term, of the second half of his book, one would expect Rahe to be scrupulously attentive here. He is certainly interested in quoting from these pages, and he does so four different times in different ways (nearly always in English). First on page vi as one long, unreferenced epigraph; then on pages 186-88, where key words and phrases are cut and pasted into his own prose (the technique I earlier referred to as Tocqueville sauce); then again on page 237, where some of the most jarring images ("immense tutelary power," "herd of timid and industrious animals") are recycled into Rahe's diagnosis of what he calls "the French disease"; and then once more for good measure on page 270, where large portions of the whole passage are again interwoven with Rahe's prose to form the concluding paragraph of the "Despotism of Administrators" chapter. But that's not reading, that's typing. 
A more careful reading of these four reiterations would go beyond the framework of this survey, but it would be hypocritical of me to pass on without noting how, for example, Rahe uses Tocqueville to effect the transition he wants to make between "long ago" and "France today." In the key paragraph on page 237, Rahe plays political pundit, opining that even if (then) French president Nicolas Sarkozy "succeeds gloriously, in the manner in which Thatcher did... it is hard to imagine that he would move decisively beyond what she achieved-in the direction of dismantling the administrative state or dramatically reducing its size and scope." 101

Then comes the Tocqueville sauce whose main function is to make the reader swallow that opinion and give it the allure not just of argument but of "brute fact."

For what Tocqueville discerned in embryo long ago is now a matter of brute fact. Over the people of France today, as he feared would someday be the case, there "is elevated an immense, tutelary power, which takes sole charge of assuring their enjoyment and of watching over their fate," and it threatens to reduce this astonishingly talented nation "to nothing more than a herd of timid and industrious animals, of which the government is the shepherd" (II.iv.6, pp. 265-266). It is a truly astonishing sight. (237)

When I read this passage, I am first struck by the effort at yoking (zeugma in the rhetoric manuals) attempted with "astonishingly... astonishing." Rahe is dumbstruck, he seems to be saying, by how sixty-five million people can be so dumb. Such talented people behaving like a herd of animals-astonishing! But, what about that herd metaphor? Hasn't it been used as an unfair put-down, insulting to animal intelligence, by superior feeling anthropocentric humans since forever? My point is that herd animals, real ones, are neither timid nor industrious - those are projections we've learned from Aesop and La Fontaine-they're just doing what comes naturally to them; and man, whose true nature is closer to that of a pack animal, like the wolf, than to either a herd animal, like the emperor penguin, or to a solitary animal, like the tiger, should perhaps neither emulate nor condemn the evolutionary success of other species. 
Many herd animals existed before man appeared, and perhaps some will outlive our species.

Second, note the embryo metaphor that attempts to naturalize the history of the French nation as progressing in a deterministic way (acorn to oak) rather than in a more open, things-could-have-gone-differently way. This is a bit surprising coming from a history professor, since one assumes that historians all judge certain "hours" and "moments" to be finer, graver, or rougher than others, no matter where they position themselves on the continuum between "hero" historiography and "forces" historiography. Third, note the clever pun effected with "brute fact." Fourth, note the telepathy effect accomplished with "Over the people of France today, as he feared would someday be the case" - as though Tocqueville really had in mind Sarkozy's presidency under the Fifth Republic when he was writing in the 1830s.

When I read the Tocqueville passage, it strikes me that one source of its seductive power is that it never specifies any particular time frame or people. This indeterminacy, perhaps the result of Tocqueville's alternating, ghostlike interest and disinterest in the material world, may be what has allowed generation after generation of readers of this passage to color in Tocqueville's spooky outline as they wish. Wow, he's predicting the Soviet Union, the British Labor Party's "Nanny State," France's Fifth Republic, "Obamacare," etc. But that's not careful reading, that's reading into the text.

Nevertheless, aside from the questionable use of Tocqueville sauce to sharpen certain complaints, Rahe does give the reader some important historical information and political judgments that are worth considering. For example, besides the more commonly cited motives Tocqueville may have had for going to America, Rahe reminds the reader that Tocqueville was looking to confirm or refute democracy skeptics like his onetime teacher and future political adversary Guizot who believed that representative government would and should evolve toward an oligarchy of superior men (like himself) ruling over the ordinary masses. ${ }^{102}$ This rivalry with an intellectual father figure, along with the rivalry with his royalist biological father and other peers, seems plausible. ${ }^{103}$ But when he got to America, he didn't see the mass of men leading lives of quiet desperation. "Beat 'em or join 'em?"- that's the question I imagine Tocqueville asked 
himself, in impeccable French of course. And though ultimately he fails to beat them definitively (Democracy in America offers no knockdown argument for or against democracy), he nevertheless refuses both royalists and socialists and sides instead with God, a catholic God-small cwhom he has decided is a Democrat in favor of popular sovereignty and not a Republican who would prefer a grand guardian class of rulers, and this despite being himself the ultimate Ruler.

A second useful reminder reminiscent of Adam Ferguson's 1767 declinist warnings ("Of Relaxations in the National Spirit, incident to Polished Nations") comes in this passage that starts off Rahe's "Despotism of Administrators" chapter.

In the face of Europe's decline, Americans should not gloat or be smug-for, unless something dramatic is done in the near future, the odds are good that we will follow our European cousins on the path that leads to servitude. After all, in the course of the last century, we, too, contracted the French disease; and among us today, under Democrats and Republicans alike, the malady advances at a quickening pace.

This development Alexis de Tocqueville did not foresee. His worries concerning the United States were of another sort. He was a great proponent of administrative decentralization and local self-government, but it would be a grave error to think of him, in American terms, as an Anti-Federalist. In the 1830s, when he pondered the American prospect, he worried far less about the dangers attendant on centralized administration than about the possibility that the American union would come apart. Like Alexander Hamilton, for whose political perspicacity he evidently had great admiration, he was sensitive to the fact that state and local governments were present to the populace in a way that the national government was not and inspired a measure of loyalty that it could not match, and he was acutely aware of the tensions generated between the South and the North by the presence of slavery in the former and its gradual disappearance from the latter. (242-243) 
The first paragraph is Rahe's sententious diagnosis and prediction, now applied to present-day America. To my knowledge, Tocqueville never says that the "social state" of one people, whatever it may be, is easily transmitted to another. On the contrary, the specificity of the history, laws, and mours in each case tends to make exporting or importing democracy-which relies so much on local circumstances and energies-difficult. ${ }^{104}$ Therefore the risk of infection or catching some "French disease" may be a fanciful misreading more appropriate to a creative writing workshop or a paranoid Homeland Security immigration policy debate than to a history department. ${ }^{105}$

More interesting is the second paragraph, which continues for a little over half of the next page. First, note how Rahe asserts with no argument that Tocqueville did not foresee "this development." Which one does he have in mind? He has just named at least four developments (Europe's decline, American smugness, Americans contracting the French disease, the "quickening pace" of that disease). In any case, it's not clear why Rahe would consider Tocqueville to have been so prescient about the Fifth Republic but blind when it comes to the future of America. Of course it does allow him, Rahe, to have the privilege of being the visionary when it comes to America, but could that be the only reason?

Second, it may indeed be an error to think of Tocqueville in "American terms"-i.e., translated into the American context-but that's no less true of anyone else's writings, since all translation is impossible, and yet we all do it, more or less carefully and well, all the time. At any rate, I agree with Rahe that it would be incorrect to think of Tocqueville as an Anti-Federalist. But it's also hard to think of him exactly as a convinced Hamiltonian-style Federalist given his praise of local associations and community spirit. Yet wasn't this true for a lot of people at the time? Remember how close the ratification vote on the Constitution was in several key states. Really the whole thing could have gone either way. (NY 30-27, MA 187-168, VA 89-79). Like a lot of people, then (1788, $1835,1840,1848,1850,1860$, etc.) and now, Tocqueville saw on both continents the real and potential strengths and weaknesses of both union and disunion-of a confederate republic of states (in France régions and départements) united as one probably wealthier, stronger nation versus a 
collection of smaller and probably weaker entities, though perhaps also more cohesive, responsive, and maybe responsible and accountable.

If in France the risk of getting the centralization versus regionalism equation wrong has sometimes been a debilitating quagmire of resentment, distrust, fear, antipatriotism, and low productivity that spreads out between Paris and the provinces, I agree with Rahe that Tocqueville saw plainly the potential dissolution of the United States over the slavery issue (for economic as much as moral reasons). ${ }^{106}$ Tocqueville recognized that in an age when public virtue can be hoped for but not counted on, because, as Publius says, "men are ambitious, vindictive, and rapacious" (Federalist \#6) and tend to follow their interests and those of their peer group, a nation in which large numbers of people think differently about a major issue (such as slavery) is unlikely to survive.

The Kentucky and Virginia resolutions (to disobey federal law) and the rise of political parties, which Rahe mentions in the second half of this paragraph, are further symptoms of the fragility of the American union that Tocqueville was sensitive to. Why he wouldn't or couldn't have been equally sensitive to the threat of a "despotism of administrators" in the American case, as Rahe claims, is unclear to me, since the signing over of one's right to political participation to a select group of managers, albeit elected, does not seem to preclude "soft despotism" from taking hold in the U.S. if the auxiliary precautions of its laws and customs (i.e., the selfcorrecting feedback loops of democracy: an independent judiciary, a free press and other free institutions, and the right to freely associate whether to talk about God, politics, business, or sports) were to break down from abuse or disuse, or if government were to become completely outsourced to a professional-managerial class of administrators. ${ }^{107}$

When it comes right down to it, I think Rahe has been taken in by the astonishing, spooky passage he can't stop quoting from, and just plain wrong if he is claiming that the drift of Tocqueville's argument in Part Four of DA II is that Soft Despotism is the biggest and worst evil that should be avoided at all cost. At the end of the "French Disease" chapter, Rahe writes, "In short, in France, Tocqueville's worst nightmare has largely come true" (236-237). I disagree. First, it's not certain the animals of France (all species considered) are suffering as much as Rahe and others may want us to believe. Second, let's recall that Tocqueville's true 
worst nightmare is "a bunch of guys with a guillotine killing all your relatives” (Gopnik, 214) — and for good reason, it already happened once!

Tocqueville, who had his practical side just like Publius, renounces looking for the ideal Democracy or the ideal anything. He's not waiting for Godot or any tutor to step forward with some master plan, nor is he offering one. He would prefer Democratic Liberty over Democratic Tyranny, that is, if he can get it; who wouldn't? But if we can't have robust and resilient Democratic Liberty right now, for whatever combination of reasons (lack of attention, motivation, intelligence, experience, trust, etc.), it would be better to hunker down (or buck up) and accept Democratic Tyranny since it would be preferable to Tyranny tout court; i.e., Hard Despotism of the traditional kind that goes straight for the body. Besides, there's always a chance, in the fullness of time, and with a kick from man's unpredictable indocility, that things will be able to swing back in the direction of Democratic Liberty, and then some grandeur, some creativity, some love for love's sake could yet take place. So I agree with Rahe when he writes (270) that we could beneficially reassert as our motto "Don't Tread on Me" as an expression, say, of our commonly shared desire to avoid torture and other cruel and unusually invasive punishments. But shouldn't we also adopt in the characteristically American, pragmatic, keep-as-many-doors-open-as-possible sort of way, "Give me Liberty or Give me Soft Despotism"?

Another aspect of this book that deserves more attention than I will give it here is the intellectual cover that Rahe offers to the questionable doings of the so-called Tea Party in the United States. Even though Rahe does not mention the Tea Party by name, it is plain to anyone who has followed American politics since 2008 that he is sympathizing with the indocility and some of the views of that loosely organized group. Since publishing his book, Rahe has continued to express that viewpoint in more direct forums on the Internet, especially (Biggovernment.com and Commentary, for example). These matters have little direct bearing on Tocqueville studies, except perhaps for the biographical similarity that one might see between the careers of Tocqueville and Rahe insofar as they both drifted from the library and classroom to more contested areas and arenas over the course of their lives. One may wonder if Professor Rahe will go all the way, as Tocqueville did, and seek elective office to 
actually try and implement some of the policy recommendations that he casually puts forward in the final ten pages of his astonishing book.

\section{Emmanuel Todd, Après La Démocratie (2008, 312 pages )}

Emmanuel Todd became better known in the United States after the publication of After the Empire: The Breakdown of the American Order (2003). ${ }^{108}$ Its fall release was well timed to take part in the first wave of criticism of George W. Bush's war of choice in Iraq. In France, however, he often participates on the public intellectual circuit (radio, TV, glossy magazines), though less frequently than some, attuned as he no doubt is to the economics of scarcity. Todd's preferred role is to be the impromptu gadfly who takes pleasure in biting or tipping over sacred cows on all sides with a mix of edgy provocation and coolly delivered statistical analysis. He's a demographer by training, a comparatist at heart, and an author of a series of sociology- and anthropology-informed economics studies that regularly challenge received ideas. He has an enviable record as a debunker and fortune-teller. He made his name with his very first book, La Chute Finale (1976; The Final Fall, 1979), which "predicted" the collapse of the Soviet Union. Eight books later, he published L'Illusion économique: Essai sur la stagnation des sociétés développées (1998)another success, but nothing compared to the bestseller Après l'Empire (2002), which was even rumored to have caught the ear of the French Foreign Ministry and to have been influential in articulating France's decision to not take part in the American-led coalition's invasion of Iraq in the spring of 2003.

Après la démocratie, which has been translated into Spanish but not English unfortunately, is another turn of the screw. ${ }^{109}$ The book was published in the spring of 2008, roughly one year after the French presidential election of 2007. Among its many declarations on a variety of topics, there is Todd's repetition of the prediction, which he already made in After the Empire, of an immanent financial crisis throughout the West (2003, 98; 2008, 269): "The only thing certain is economic catastrophe, but we know neither its exact form nor its timing." Cool analysis or hot air? If Todd acted on his own speculation, like Mike Burray, he has 
probably become very wealthy by now as a short seller, but that kind of speculating may not interest him. ${ }^{110}$

Overall, Todd's democracy book has the same approach and contains some of the same arguments that appeared in earlier work. For example, as literacy rates go up, birthrates tend to go down; equality matters more to a universalist people (e.g., the French) that views humanity as one (brothers) than to a differentialist people (e.g., Anglo-Saxons) that tends to divide and rank mankind in distinct groups (brothers and others) according to certain criteria (e.g., skin color, religion, SAT scores); universalist empires last longer than differentialist empires, etc. In the democracy book Todd offers his theoretical spectacles again to take into account historical events in France since 2003, notably the call in some quarters for more "participatory democracy," the persistent efforts of France's far-right party the National Front to get their foot (or boot) in the door, and the presidential victory of Nicolas Sarkozy in 2007, a man who has been compared to Napoleon III, George W. Bush, and many other dubious leaders, but whom many think of as just one more lean and mean leader of traditional "republican" politics, i.e., the head of an oligarchy of trusted career politicians who rely on party discipline and staying on message. That message goes something like this: The world outside the Hexagon is nasty, brutish, and short, but that's OK because you're French, and if you vote for us, there'll be nothing to be afraid of; just work, vacation, and obey the laws that we've passed for your own good and we'll take care of you, and you'll live to a ripe old age. With some slight modifications this can also function as the message of the so-called opposition, a homogenizing tendency that exasperates wide-ranging intellectuals like Todd and confuses many ordinary people, some of whom are drawn into more extreme parties while others buy his books in search of an explanation of the big picture and "a theory of everything (sort of)."111

So where does Tocqueville fit in? Well actually he doesn't, at least not as much as one might expect, and that's one of the things I find most interesting about reading Todd. Before Zbigniew Brzezinski, Chomsky, Chua, Friedman, Gladwell, Paul Kennedy, Christopher Lasch, Oswald Spengler, or Todd, there was Montesquieu (1689-1755) and Adam Ferguson (1723-1816), Gibbon (1737-1794)... and Tocqueville (1805-1859). Anyone with the least historical, comparatist bent who's living in 
interesting times, or "between two worlds," generally devours the books of these authors and others like them. Todd has clearly read Tocqueville and may even be indebted to him for certain things. Indeed, they seem to be kindred spirits in some ways (cosmopolitan, restless, contrarian). And yet Todd chooses to not accord "notre élégant Normand" much space in his own books. Whether this is a case of Bloomian "anxiety of influence," Emersonian "self-reliance," or something else is hard to say.

In After the Empire, Todd's resistance to Tocqueville, if it even existed then, was hardly noticeable. He's only mentioned briefly four times, two of them being footnotes, and one of those is a translator's note cribbed from Seymour Drescher that tells the reader who Tocqueville was (206n3). Of the other three, one is a polite difference of opinion: Todd underlines higher literacy rates as one of the main material changes that contributes to expanding equality of social conditions, whereas Tocqueville used the catch-all fudge term providential to describe that long-term evolution (though he does discuss access to education, property, and other material causes). The second mention is a note of scholarly debt to Tocqueville for the interesting definition of Russia he sends in a letter to Beaumont: "America without the Enlightenment thinkers and liberty. A scary democratic society" (206n6). It's an intriguing "tweet" that Todd chose in turn to forward to his readers. The third mention looks like a case of collegial mutual support wherein Todd incorporates a nod to Tocqueville's Democracy in America to reinforce his own main idea: "American society has in effect recreated the three-part structure that existed at the time of independence and later when De Tocqueville made his observations at the beginning of the nineteenth century: Indians, blacks, whites" (111).

In Todd's democracy book, Tocqueville is referred to three times in a negative way. The first is by far the longest and most interesting. The second and third are two quick slaps that reinforce the negative assessment made earlier. The first slap takes the form, "One must really pay attention to $x$ and not to $y$ as Tocqueville did" (260). This is all that is likely to register with the general reader since the actual content (which requires knowing what happened on a certain August 4) is elliptically presented. Translated, the second slap says, "At the rate things are going in political philosophy today, democracy-loving intellectuals will soon miss the banal old Tocquevillism"112 (273). The expression "le tocquevillisme 
banal" leaves unspecified whether Todd is knocking Tocqueville, certain Tocqueville-inspired studies, or both.

The more detailed treatment of Tocquevelle, compared to which these two later mentions are mere glancing blows, comes in an earlier section of Todd's third chapter ("From Democracy to Oligarchy") entitled "Mass Literacy and the Emergence of Democracy" (84-88). What's evident from these five pages is that Todd is upset about the same things that bothered him already in 2003; namely Tocqueville's use of the fuzzy God-talk word providential and his negligence, according to Todd, of education, especially literacy, as a democratizing factor, which for Todd is of capital importance. So already with two strikes against him, Todd notes that Tocqueville's stock has risen lately and attracted more continuators than detractors ("plus d'héritiers que de contradicteurs"); but for Todd that's bad, not good, because these practitioners of "tocquevillisme" are only recycling "a few banal theories such as the one about a type of equality that is menacing for liberty and the one about a type of individualism that tends to undermine itself" 113 (84). The adjective banal has several meanings in French. Is Todd using it negatively to mean worn out, worthless, trivial; or positively in the sense omnipresent, common, widely accepted? I suspect negatively, but in either case, he is manifestly uninterested in being more explicit about this tocquevillisme banal, since he neither quotes or references the relevant passages where these theories come from (such as DA I, 1, 5 and DA II, 2, 2). Instead he gives a celebrity endorsement to the Le Strat and Pelletier book, calling it "excellent" and then wittily embroidering on its thesis: "in our present age of a resurgence of unegalitarian feeling, the Norman aristocrat has become a totemic figure" (85, my emphasis). This paragraph concludes with an ad hominem put-down of the presumed middle-class origins of those who study Tocqueville today just as, he says, before 1989 those studying Marx came from a similar social class. In other words, for Todd there are two kinds of readers: the intrepid who seek truth and find it in a concatenation of books that truly matter and the insecure who follow fads down blind alleys. But Todd's animus doesn't stop there.

In the next paragraph he notes that Tocqueville has become a symbol of a Transatlantic relation ("lien transatlantique"), only to ridicule that link by alleging that Tocqueville was secretly disgusted ("secrètement 
dégouté") by the United States and, unlike Nicolas Sarkozy, who was criticized by some for being too "pro-américain," would never stoop to spend a vacation in a country whose democratic mores repelled him. Without citing a specific letter or any other source, Todd claims the correspondence contains evidence that Tocqueville cut short his American stay out of disgust with those democratic mores, even though it is more frequently reported that he and Beaumont were called back for professional and family reasons (Brogan, 197). He concludes this paragraph with a dry mock: "It was all the more meritorious of him to have accepted with pursed lips the inevitability of democracy." ${ }^{114}$ But this too is misleading because it's not liberal democracy that Tocqueville claimed was inevitable, it was the expanding equality of social conditions. Furthermore, as Todd must know, democracy is never something singular or static for Tocqueville but comes in many different, usually hybrid, forms (tyrannical, aristocratic, liberal, venal, grand, petty, etc.), none of which are inevitable but depend on man's collective and individual choices and behaviors over time

In the next paragraph Todd quotes a passage from an example of tocquevillisme that he finds particularly "simplified" and "degraded." It's a study by Guy Coq entitled (I translate), "Does Democracy Make Education Impossible?” Instead of being drawn to titles that ask questions, for Todd its trendiness is repellent. He then quotes ten lines from the book and discusses the phrase "l'individu démocratique." Their gist is that democracy doesn't necessarily produce new and better men, but instead people of ambiguous value. In support of this claim, Coq turns to Tocqueville: "Let's recall Tocqueville for whom democracy's success entails a danger for its own survival, namely that the democratic individual's behavior, attitudes, and self-affirmation engenders a new despotic power" (Todd, 86; Coq, 13, my translation).

Aside from going a bit fast, jumping a few steps, and making the cause and effect relationship sound more fated with that verb engenders than I think Tocqueville really says or means, this particular instance of Tocqueville sauce does not seem abusive to me. For Todd, however, this passage serves as an example of how the "canonization of Tocqueville" squashes the necessary critical faculty. He claims Tocqueville almost got it, but didn't quite see (as Todd has) the fundamental role literacy plays in 
the birth of democracy. Todd clarifies his position: "One does not learn to read to become the equal of others, or to be a 'democratic individual,' but to be a better educated individual intellectually." ${ }^{115}$ What Todd has in mind by "a better educated individual intellectually" is as vague as the old term well-rounded; nor is it easy to see how he has refuted Tocqueville or Coq here, since he cites no text of Tocqueville that makes the claim he attributes to him, and nowhere in the passage quoted from Coq does the author embrace (or exclude) the subject of reading.

So there is no clear victor in this odd cockfight, but Todd is still intent on establishing, over Tocqueville's dead body, that the spread of literacy equals the birth of democracy "understood as the equality of conditions." He then adds, "But political democratization is only an effect, not a cause." This is rather elliptical, and its value is hard to gauge for that reason and also because Tocqueville has not been allowed to defend himself, so to speak. In the next and last paragraph of this section, Todd shows some mercy and pardons Tocqueville for not having had access to the statistical information about literacy rates that only began to be collected and published around 1826. Todd's conclusion: Tocqueville's reasoning was faulty, but it's not entirely his fault because he lacked some empirical evidence that only later research into the subject, such as mine, could incorporate into new and improved theories about the birth of democracy.

It would seem that Todd needs to get Tocqueville and his followers out of the way to clear a space for his own theorizing. This is a familiar story and somewhat understandable given the do-it-yourself spirit of democratic times-everyone wants an original relation to the universe; everyone wants to be Adam and have one's own chance to name the animals. ${ }^{116}$ Nevertheless, it's regrettable that Todd's will to open up for himself new horizons of meaning should have been done with such a crude scalpel and so little respect for Tocqueville's contribution. The result is that his book sends the unhelpful messages that the absent are always wrong, the present is superior to the past, theorists are a bunch of insecure, passive-aggressive nitpickers, and reading Tocqueville is a waste of time. Literacy may be a necessary condition for democracy (though I would want to ask anthropologists more about that claim), but it is hardly sufficient (look at Cuba). Also required are certain customs and dispositions, what Tocqueville called mours, and these would include 
agreement about the basic rules of engagement (such as good manners, mutual respect, security, generosity, honesty, and trust). The scarcity and fragility of those qualities might account in part for why democracy is so difficult to establish and sustain even among highly literate populations.

Another matter raised in the closing pages of this book is Todd's policy recommendation to his universalist compatriots and other Europeans that the only way to safeguard European democracy is to adopt me-andmine-first practices of protectionism; in other words the establishment of a differentialist hierarchy (an "invidious distinction" as Veblen would say) into brothers and others (e.g., European / not-European) with the attendant consequence of unequal treatment accorded to each. Is this an apology for "fortress Europe" or "La France forte" (Nicolas Sarkozy's 2012 campaign slogan)? Or is it intellectual cover for right-wing nationalism? Or an excuse for a new kind of exclusionary democracy like the American one Tocqueville studied that advanced in predatory fashion via "force and fraud"117 on the backs of women, blacks, and Indians (now women and "Arabs")? If so, is it really the best policy for Europeans or others to adopt now? Why? Why not? Moreover, for Todd this protectionism is not just about the circulation of people and material goods, but seems to extend to the marketplace of ideas as well. Is this underwriting of a division into strident factions wise? We may wonder if there aren't better alternatives.

\section{Agnès Antoine, L'Impensé de la démocratie: Tocqueville, la citoyenneté et la religion (2003, 410 pages)}

Why Todd should want to practice protectionism against Tocqueville, why he shepherds the reader away from the elderly "elegant Norman" as though he were senile instead of treating him like a brother, a familiar, a colleague as interested in the good, the true, and the beautiful as the next person, are mysteries that lead me to wonder if democratic association within even the most liberal, inclusive democracy is not always also dependent on an expulsion and continued exclusion of something or someone as part of the constituting frame or foundation of itself. Might this be part of what Agnès Antoine is getting at when she speaks of "l'impensé de la démocratie"? 
Another technique for drawing the reader in besides using a title question (Stanley Fish's Is there a Text in this Class? is a famous example) is to use a noun in one's title, such as impensé, that doesn't exist in the dictionary as such, but whose existence we can logically imagine since it is constructed out of something that does exist: the verb penser, to think, and its past participle pensé, thought, which is not exactly the same thing as une pensée, a thought, or la pensée, (the) thought. So with the prefix im-, l'impensé would then mean the unthought or the not thought. Follow this nonexistent (because as yet unthought until now!) noun impensé with a genitive construction, de la démocratie, and you add another layer of intriguing complexity because of the objective/subjective genitive ambiguity. So the title could be naming either democracy's unthought, what democracy has not thought about, but knows it possesses and is maybe just keeping in reserve for later, or something that democracy doesn't have a clue about, not the slightest idea of, because it lies outside, beyond democracy's ken, beyond what it can ever know or imagine. The latter would be closer to something we're more familiar with; at least the notion exists as entries in the dictionary, i.e., l'impensable, the unthinkable, and l'inimaginable, the unimaginable. So is it $x$ or $y$, or both $x$ and $y$ ? And then comes the subtitle, a list of three items-a proper noun and two common abstract nouns: Tocqueville, Citizenship, Religion. There is not a colon or equal sign between the title and subtitle, but sophisticated readers familiar with such titles often add, infer, or read them into the title. ${ }^{118}$ Then the subtitle would be naming three "things" that are unthought by democracy-things democracy has not (yet) thought about, because it is keeping them in reserve, or three things that democracy cannot think about, because they are beyond its reach, beyond its grasp, properly unimaginable, unthinkable. Or "repressed," as Françoise Mélonio suggests in the conclusion to her study Tocqueville and the French.

People who find such observations interesting and not simply annoying - perhaps because they too enjoy puzzling over things and believe that figuring something out and knowing it is, like virtue, its own reward-are generally drawn to philosophy and may even, under rare circumstances, rare under any regime let's recall, become professional philosophers themselves. Agnès Antoine has had the good fortune, and manifestly done the hard work that puts luck on one's side, to become a 
professional philosopher, and she is the author of a book on Tocqueville that could be fairly characterized as grand, important, big. That it will probably not be read by the likes of Le Strat, Pelletier, and Todd, because for them Tocqueville is bagged and tagged forever it would seem, is not something she is likely to lose any sleep over. Should she? For others, perhaps, her book will not remain a dead letter, but instead add to their knowledge and understanding of all four of the things named in her title-democracy, Tocqueville, citizenship, religion — as well as that fifth most strange "thing," l'impensé.

Remember Tocqueville's contrarian declaration in DA II, 1, 15, that the study of Latin and Greek is to be recommended to those living in democratic times because they usefully recall and may reinstate qualities that tend to drop out of everyday life within a democracy, namely "admirable mastery of technique and care in rendering details," as well as patience and motivated choices (545). He doesn't say everyone should become a classics major however.

It is obvious that in democratic societies individual interest as well as the security of the state requires that the education of the majority be scientific, commercial, and industrial rather than literary.

Greek and Latin should not be taught in all schools, but it is important that those destined by nature or fortune to cultivate literature, or predisposed to savor it, find schools where it is possible to gain complete mastery of ancient literature and steep oneself in its spirit. A few excellent universities would do more to achieve this result than a host of bad schools in which superfluous subjects taught poorly stand in the way of teaching necessary subjects well.

Everyone who aspires to excel in literature in a democratic nation should feast often on the works of Antiquity. There is no more salutary hygiene.

Not that I consider the classics beyond reproach. I believe only that their special qualities can serve as a marvelous counterweight to our peculiar deficiencies. They prop us up where we are most likely to fall. (G546) 
Here is food for thought for harried students, professors, deans, college presidents, and legislators. I would go further (and forward in time) and extend Tocqueville's recommendation to all texts written before the two World Wars, because 1914, roughly speaking, has now become the new dividing line today between Antiquity and Modernity, between what people today can still find more or less familiar and what stands as foreign to us as Greek and Latin were already to Tocqueville's contemporaries. I only regret that Tocqueville was not more explicit about how he envisioned the transfer of knowledge and sensibility from the classics major who feasts often on the works of Antiquity (which I'm saying these days could just as well be the writings of Tocqueville as Tacitus) and the majority of "us" who are obviously required to devote ourselves to scientific, commercial, and industrial arts rather than to literature, philosophy, and other nonvocational topics in the arts and sciences. When and how will that counterweight, that "prop" as Tocqueville calls it, be applied and effectively do the compensatory balancing or steadying, also called a "salutary hygiene," that will allow democratic man to regain and perhaps retain a better equilibrium? I've not yet found the answer to that question in Antoine's book either. But maybe I have not read carefully enough. Or maybe it's not there because she has not thought about it. Or maybe she has thought about it, sort of, but is keeping her thoughts in reserve for now and will tell us more about it later.

In any case, I'm convinced that reading Antoine's book would be a salutary counterweight in democratic times. Where others are restless, she is calm; where others are in a hurry and interested in getting the most with the least effort, she proceeds patiently with a serene aristocratic disinterest for any possible conversion of knowledge into fungible capital. While others have deadlines, she seems intent on constructing her argument with the same transpersonal outlook as the cathedral builders of olden times. The long maturation of her thought will take however long it takes, her own individual contribution being of little importance next to that of the work itself which began before her and will continue after she, AA, has turned to dust.

I'm also convinced she is devoting her time and effort to what matters most to Tocqueville once he has discovered America and how democracy works, namely the compensatory counterweights to democracy's 
"peculiar deficiencies" (G546) and self-destructive tendencies. Two of these counterweights are citizenship (which maintains community spirit) and religion (which stimulates projects and productivity while discouraging excess individualism, materialism, and nowism). A third counterweight, which Antoine enacts more than she discusses it, is the pursuit of a literary education; for example, feasting often on the works of Tocqueville, the first social scientist, and other scientists, philosophers, and artists. It is obvious that in democratic societies, only a minority will by nature or fortune be drawn to Antoine's Tocqueville book. ${ }^{119}$ But those who are so drawn should be allowed to read her and not be obstructed in any way or treated with contempt by the rest of us. Why? Because it's in our collective best interest properly understood ("bien être proprement entendu") that they be freely allowed to do so.

It therefore seems juste et bon to include a passage, chosen at random, from Chapter Twelve ("La Dialectique Tocquevillienne"), entitled "La modernité et la réhabilitation de la chair." We can cut in midsentence:

... the contemporary slide towards the flesh is dismaying. It represents a simple inversion of the preceding imbalance and a new extreme. One humanity, that of the former or "aristocratic" society, had reached too high, forgetting all other men. Another, that of democratic society, took into account the totality of human beings, but being preoccupied mostly with caring for well-being, it finds itself too low, and does not yet constitute a true humanity. Therefore, one must strive for a new balance, by giving the well-being society the possibility to rediscover more spirit. To guarantee the existence of this just middle within the democratic condition, the civic dimension is for Tocqueville the fundamental mediator. It helps the individualistic person raise herself from the sphere of material interests, just as it helps the religious believer not lose sight of the world. As in Aristotle, the important thing is to live neither above nor below humanity, and the man who places himself outside the city is, definitely, a brute animal or a god.

This perspective allows one to better understand Tocqueville's "aristocratism." Tocqueville dreads the democratic condition's leveling effect on man's grandeur, but in no 
way does he recommend a return to the former social order, despite that order's inherent beauty; nor does he wish to recreate a new aristocracy based on other social criteria. If something from the aristocratic condition is to remain present, it is not a social reality, but a dimension of being, a desire, an élan, an energy - that which pushes man to transcend in himself the animal and point his efforts in the direction of the high. At the same time, however, it is not about substituting for the mediocrity of the "last man" a new species of "overman," as Nietzsche attempted, even though his critique of the democratic, bourgeois order might seem, in some ways, to be a radicalization of Tocqueville's intuitions. (264-265, my translation)

By chance we've hit on a passage that (1) touches on the main thesis of Antoine's book-the necessity of democracy's supplements (Tocqueville, citizenship, and religion), which it protects even while sort of ignoring them; (2) features the need for striking a new balance as mentioned above in the context of Tocqueville's recommendation to protect and honor the voluntary pursuit of a literary education; and (3) shows Antoine practicing what she preaches, so to speak, with a piece of careful reading that is attentive to making sure the reader does not fall into misunderstanding. There is an evident desire for clarity as her prose guides the reader with its parallel repetition, "Une humanité, celle de... Une autre, celle de..."; phrases that underline the point to be understood: "Il faut donc... il s'agit de... Il ne s'agit pas de..."; and the judicious use of outside points of reference: Aristotle, Nietzsche. The latter are offered tactfully, as tools to even better understand Tocqueville's position, but they are optional, like hiking with ski poles, and the reader who knows nothing about Aristotle or Nietzsche is not made to feel stupid, excluded, or blocked from understanding and continuing to follow the argument.

Antoine's strategy and tactics exemplify the still dominant approach to reading in France; namely, critical explanation or interpretation that they call explication de texte or commentaire de texte. It is an approach that considers it to be in the reader's best interest to place the text first and try to serve it well by illuminating its truth and protecting it from possible misinterpretation by roving wolves or thirsty leopards who might 
willfully attempt to drag it off in other directions or change its spots. In Tocquevillian terms, one could say it's a form of rational patriotism within the republic of letters. It is a way of reading that tends to be conservation-minded, literal, and spiritual, and aristocratic in the sense that it believes in good, better, best, takes the long view, lives frugally off the light and nourishment engendered in the encounter between reader and text, and draws as little attention to itself as possible, convinced that individualism and narcissism, like Pascal's "moi," are "haïssable” and vulgar.

People raised in democratic lands where individualism, materialism, and nowism may have been allowed to develop unchecked can find reading a book like Antoine's unbearable or, on the contrary, wonderfully liberating, a refreshing change, a salutary counterweight to democracy's short-term thinking, pragmatist bullying ("There is no alternative"), and unquenchable thirst for news, novelty, change, progress. ${ }^{120} \mathrm{I}$ for one admire the way her 410 carefully composed pages push back against the general passion ("engouement général"). Just as I like the rock in the reproduction of the painting that was chosen to adorn the cover of her booka rock that juts up above the water on which two fur traders in a long canoe are floating with their goods and their cat, all three staring out at a spectator on the riverbank, if there is a spectator. ${ }^{121}$

\section{Jon Elster, Alexis de Tocqueville: The First Social Scientist (2009, 202 pages)}

Jon Elster starts off his Tocqueville book with a personal testimony about his first and second experiences reading Tocqueville:

I first read Tocqueville almost fifty years ago, as part of my French studies at the university. As I was largely ignorant of social science and of history, I was unable to benefit from him. When I returned to Democracy in America fifteen years later, having spent most of the intervening years learning those disciplines, I had an experience I have only had with two other books, Thomas Schelling's Strategy of Conflict and Paul Veyne's Le pain et le cirque. The work put me in such a state of intellectual and nervous excitement that I could not 
sit still, but had to get up from my chair and walk about from time to time.

When I tried to penetrate more fully into the work, its brilliance began to seem more blinding than illuminating. (vii)

This autobiographical anecdote is valuable for many reasons. First, it humanizes the author by recalling for us, his readers, that he too was a reader once, "clueless in academe," and later, though older and smarter, still challenged and ill at ease with a set of texts that both stimulated and blocked his efforts at understanding, texts that were teaching him more and better than almost anything he had ever read, but that still remained somehow unknowable, unmasterable. The feelings of exhilaration, frustration, adventure, and humbleness expressed here are emotions most readers who take on the task of reading nine hundred pages of argumentdriven prose can relate to, and this creates sympathy or shared feeling between him and us. Second, it reminds us of something that is easy to forget: the words on the page may not change, but we do, and therefore we never step into the same text twice no matter how familiar we may think it has become for us. We may think we're reading the same text, and in a sense we are, but the text is reading a new you every time you read it. Third, it enthusiastically puts Tocqueville's texts in a constellation with two others that we can file away for later and test whether we have the same reaction as Elster. And fourth, by being so intimately confessional with the reader from the start, it also allows him to put the personal aside, because it's clear from what follows that Elster, like Antoine, does not want this to be about him. He merely wants to be a helpful guide to those who are inclined to make use of his services as an experienced reader of Tocqueville, a pedagogue, and a fellow social scientist. ${ }^{122}$

His focus will be Tocqueville and especially Tocqueville's texts, and among those many pages he concentrates our attention on the least biographical and empirical dimensions, which he names in the second paragraph "small and medium-sized causal mechanisms and highly sophisticated methodological insights that"-and now here comes the claim that Elster will defend in the next two hundred pages - "although they do not add up to the grand theory to which he aspired, have lasting value. Even today, it seems to me, they are not as fully explored and utilized as they ought to be" (vii). 
Translated into the language of mid-twentieth-century philosophy of language, Elster's book could be entitled "How to do things with Tocqueville." In the language of the Internet age, it is the Tocqueville "apps" store with Elster as the general manager in charge of inventory, configuration, and local installation. His book could be compared to Gene Sharp's free, downloadable, how-to manual, From Dictatorship to Democracy: A Conceptual Framework for Liberation (4th edition, 2010) that is reported to have been widely read and highly influential during the Arab Spring. ${ }^{123}$ There are a few differences though. Sharp's inventory of strategies, tactics, and methods is more succinctly presented (93 singlespaced, large-type pages), and it addresses the roughly 2.5 billion people who are living in countries officially designated as "not free." Elster's book contains about four times as many words and could be addressed to readers of any political persuasion from dictators to democrats because it is not arguing in favor of any particular form of government but instead sticks to its self-imposed pedagogical mission of highlighting frequently overlooked causal mechanisms and insights in Tocqueville's text that could be used in many ways - to promote democracy, to foil democracy and favor liberal or tyrannical republicanism, or other purposes. In this way Elster's book and by association Tocqueville's texts (which Gene Sharp never mentions) are potentially more useful "playbooks," since the range of possible applications is much wider.

Before turning to a partial inventory of the Tocqueville tools that Elster's book passes along at little cost to the reader, it's worth noting Sharp's constant attention to the open-ended, probabilistic nature of politics and his reminder that "the conflict in which political defiance is applied is a constantly changing field of struggle with continuing interplay of moves and countermoves" (34). This sounds very much like Tocqueville, especially the later politically seasoned Tocqueville of $D A$ II, Recollections/Souvenirs, and The Old Regime and the Revolution. Here is a passage, for example, from a section of Sharp's Chapter Two ("The Dangers of Negotiations") entitled "'Agreeable' Dictators":

Dictators may have a variety of motives and objectives underlying their domination: power, position, wealth, reshaping the society, and the like. One should remember that none of these 
will be served if they abandon their control positions. In the event of negotiations dictators will try to preserve their goals.

Whatever promises offered by dictators in any negotiated settlement, no one should ever forget that the dictators may promise anything to secure submission from their democratic opponents, and then brazenly violate those same agreements.

If the democrats agree to halt resistance in order to gain a reprieve from repression, they may be very disappointed. A halt to resistance rarely brings reduced repression. Once the restraining force of internal and international opposition has been removed, dictators may even make their oppression and violence more brutal than before. (13)

Aside from certain thematic resemblances to the famous Part Four of DA II, what attracts my attention, now sharpened by what I've learned from reading Elster, is the repeated use of may (i.e., possible/probable, maybe/maybe not); the use of cause and effect formulas such as "effect $x$, if cause $y$ / if $y$, maybe $x$ "; and especially the warning in the last sentence to beware of making concessions because you could end up in a worse situation than before, which sounds a bit like the folk wisdom "Be careful what you wish for." It is also similar to the set of cause and effect scenarios that Elster groups under the heading "Precipitants: the Tocqueville Paradox" (162-169) — the crucial resemblance being the observation made by both Sharp and Tocqueville, and highlighted by Elster, that in real life the actual consequences of an action may be other than the hoped for consequences and may even be precisely the opposite of what the action aimed to achieve. ${ }^{124}$

Shakespeare and other writers of comedies and tragedies going back to Antiquity have always known this of course, but literary irony is not generally considered to be the stock in trade of social scientists. This makes Sharp's, Elster's, and Tocqueville's attention to backfiring, backlashes, boomerangs, and the other ironies of everyday life all the more special and striking to the social science reader who may have thought she was in the "real world" of more knowable, static truths-even though Tocqueville repeats over and over that democratic times are characterized by constant change, mobility, dynamic tensions, and blended contradictory impulses and identities. ${ }^{125}$ 
Tocqueville's discoveries, which all have as their source his insight into the not-necessarily-Newtonian physics of the mind, are not presented as a mere list of forces, but as an intellectual narrative that is argued and directed. ${ }^{126}$ With its embrace of a formation-of-thoughts-while-thinking approach, Tocqueville's text is obviously closer to the French essay tradition of Montaigne and Montesquieu than it is to a PowerPoint presentation. Nevertheless, it's helpful to us here in the Internet age to have Tocqueville's innovative achievement highlighted by Elster's rigorous translation of Tocqueville's lively prose into more easily graspable discrete units. Taking a cue from Sharp's book, Elster could go even further in that direction and add an appendix with a glossary if he gets a chance to rework his book for a second edition.

Elster clearly states his interest in Tocqueville in the Introduction: "the main task I set myself is to elucidate the structure of his arguments, their validity, and their relevance for us today." This relevance depends on proving that Tocqueville's writings offer "exportable causal mechanisms." Note, his claim is not the same as that of utopian, ideal State theorists from Plato down to modern times for whom designing, installing, and fine-tuning a given political regime, as though it were a computer operating system, seems entirely feasible. The causal mechanisms that he calls "exportable" are in effect underappreciated but knowable laws of psychology, especially group dynamics, and their exportability is predicated on certain universalist assumptions about how all our minds work, individually and collectively.

Among these laws are those that concern, for example, "preference formation." Elster lists three: the spillover effect ("behavior $p$ in context $x$ will be repeated in context $y$ "), the compensation effect ("not behavior $p$ in context $x$, but behavior $p$ in context $y$ "), and the satiation effect ("not behavior $p$ in $x$, not behavior $p$ in $y$ ") (13). Elster's goal is to train the reader's ear to hear Tocqueville using these analytical tools to make observations about the relationships between behaviors across one or more spheres of activity. These spheres include "religion, literature and the arts, politics, warfare" and "civil society" or "private life" (14). On the next page, Elster gives an example of Tocqueville observing how the spirit of risk taking and risk loving spills over from industry to warfare: 
Men in democracies naturally feel a passionate desire to acquire quickly and enjoy easily the goods they desire. Most adore risk [le hasard] and fear death far less than toil. It is in this spirit that they pursue commerce and industry; and this same spirit, when they carry it to the battlefield, makes them willing to risk their lives in order to assure themselves in an instant of the spoils of victory. No form of grandeur satisfies the imagination of a democratic people more fully than military grandeur, which is spectacular and sudden and obtained without effort, merely by risking one's life. (Elster, 15; DA II, 341, G775)

The persuasiveness of Tocqueville's argument depends on accepting at least (1) the feeling he claims democratic man has ("a passionate desire to acquire quickly and enjoy easily the goods they desire"), (2) the transfer of that feeling to another context ("It is in this spirit that..."), and (3) the stable reality of "military grandeur" and "the imagination of a democratic people." If no doubts are raised about any of that, chances are the reader will find Tocqueville's spillover observation perceptive and convincing.

Another area that interests Elster is Tocqueville's analysis of "Belief Formation" (Chapter Two), especially conformism. He claims that "Next to 'the Tocqueville paradox,' [it] is probably the piece of analysis in his writings that has had the greatest influence on social science" (40). He gives several examples of Tocqueville's observations about conformity, many of which rest on the presupposition that similar causes produce similar effects. Consider, for example, this passage from DA II.

Men equal in rights, education and fortune-men of like condition, in short-necessarily have needs, habits, and tastes that are not very dissimilar. Since they see things from the same angle, their minds are naturally inclined towards analogous ideas, and while each of them may diverge from his contemporaries and form beliefs of his own, all end up unwittingly and unintentionally sharing a certain number of opinions in common. (Elster, 40-41; DA II, 318-319, G754) 
In this same chapter, but developed further in Chapter Six, "Patterns of Social Causality," is Elster's commentary on Tocqueville's doubts about the possibility and sustainability of so-called halfway houses, i.e., intermediate "centrist" positions where one might try for bargains, compromises, or half-measures with the idea of attaining harmony or getting the best of both worlds, and instead one ends up with more conflict and less power or advantage than before. This presupposition (an apology for hard-liners and an admonishment to compromisers?) conditions Tocqueville's pronouncements about the dynamics of equality at the end of $D A$ I, 1, 3:

I know of only two ways to achieve the reign of equality in the world of politics: rights must be given either to each citizen or to none.

For nations that have achieved the same social state as the Anglo-Americans, it is therefore quite difficult to perceive a middle term between the sovereignty of all and the absolute power of a single individual. (DA I, 115, G60)

The weakness of halfway houses also conditions the "hang together or hang separately" thought lower down on the same page.

Furthermore, when citizens are all almost equal, it becomes difficult for them to defend their independence against the aggressions of power. As none of them is strong enough to fight alone with advantage, the only guarantee of liberty is for everyone to combine forces. But such a combination is not always in evidence. (DA I, 116, G60-61)

The idea here is that a group may try and win liberty for all together or risk seeing it taken away from each individual one by one. This almost sounds like Tocqueville coming out in defense of labor unions, with a cautionary doubt raised in the last sentence about how often they might really win their battles due to the difficulty of forming efficient collaborative groups.

The phrase "all almost equal" is typical of another theme that Elster explores, which is Tocqueville's sensitivity to how cause and effect relationships as well as perceptions of size (large, medium, small) can vary depending on whether one is living in a state of approximate equilibrium 
(in a democracy or under absolutism, for example) or transitioning between steadier states (such as during a revolution). As always, Elster keys his remarks to examples from Tocqueville's text. Thus, a sentence praising freedom of the press in a democracy as "the only cure for most of the ills that equality can produce" is juxtaposed with a warning about the harm a free press can cause when it occurs in contexts where it had previously been absent: "Woe unto those generations that abruptly introduce freedom of the press for the first time!” (DA I, 272, G213). Forgetting the difference between "transition effects" and "equilibrium effects" says Elster, echoing Tocqueville, can cause a lot of confusion, misunderstanding, and harm.

Ultimately, Elster's pedagogical laying out of Tocqueville's contributions to social science permits asking clearer questions about "the quality of democratic government" and the possibility and probability of containing "the pathologies of democratic government" (147-149) within reasonable, nonfatal limits. These are similar to the questions the American framers asked in Philadelphia and that Publius tries to answer in The Federalist. In Elster's plain style the question is posed this way: “To assess the quality of the system we may ask, therefore, whether it tends to produce wise aggregate beliefs and just aggregate values" (145). In other words, with statistical tabulation of choices (essentially "votes" of all kinds) over a sufficiently lengthy and broad sample space, we can measure the wisdom and justice of this or that regime, with whatever mix of democratic, oligarchic, or monarchical components it may have. It will test, among other things, the "wisdom of crowds" to see to what extent it really exists and to what extent it may be merely the ideological preference, the wish, of democracy sympathizers. ${ }^{127}$

Elster also stresses how important it is to have enough time. This is especially true for democracies, says Elster, echoing Tocqueville, because if people in democracies are guided by the principle that "the interests of the many ought to be preferred to those of the few" (Elster, 145; G285), and if they are able to correct their mistakes and counteract their own worst tendencies, then they may, in the long run, be able to avoid the ten "pathologies of democratic government" that Elster distills from his reading of Tocqueville (147-149). But in the short term, democracies frequently make bad policy choices due to "motivational and cognitive 
deficits" (144). This underscores the importance of making "repairable mistakes" (DA I, 318, G258) — something democracy is good at-but this takes time, which is uncompressible. ${ }^{128}$ Here again is Elster's commentary (147):

The crucial condition is that they have enough time for the learning to take place: they must have "the faculty of committing errors that can be corrected" (G258) The Americans have this enviable faculty because their geographic isolation ensures that they have no enemies who might exploit a momentary weakness (G192-3). "But democracy can discover truth only through experience, and many nations will perish before they have had an opportunity to learn from their mistakes" (DA I, 258). Even when a regime is free of any tendency to make systematic mistakes, a single large mistake might, in a hostile environment, be enough to bring it down. An implication is that "in order for a democratic republic to survive easily in a European nation, all the other nations of Europe would have to establish democratic republics at the same time." (G256)

It's easy to see from this passage why Tocqueville was picked as Foreign Affairs minister in 1849 even though there's doubt about whether he really did a good job or, we may add, had enough time (less than two years) to learn from and repair his mistakes. ${ }^{129}$ Along the same lines, it's tempting to think Elster's Tocquevillian sensitivity to the influence that geography, neighbors, and other variables have on public policy (leading to outcomes that are more or less wise and just) would make him a good consultant in Brussels, Paris, London, or Cairo; but then again that same knowledge might lead him to hold tight to the arms of his chaire at the Collège de France and be thankful for the chance to continue making his living peacefully in amphitheaters, libraries, and his study.

Unlike Rahe's ten-page Conclusion, which may strike some readers as a rather abrupt passage from the classroom to the war room, from talking points to bullet points, Elster's last ten pages follow the advice to orators at this stage of the game ("Tell 'em what you told 'em") and provide a clear summary of what he considers to be Tocqueville's key insights and 
strengths as a researcher. He then offers a diplomatic assessment of what Tocqueville's future role might be.

Even if the spillover effect turns out to be a marginal phenomenon or envy to be less important than Tocqueville thought it was, his work can still remain as an inspiration. It is important to understand what it could be an inspiration for; not for the construction of a general theory of the kind proposed by Talcott Parsons and his followers, but for the fine-grained analysis of a given society or regime. ${ }^{130}$

In other words, Elster is not claiming that air-dropping copies of Tocqueville over Europe, the Middle East, or other hot or cold war zones will solve the world's problems. He does believe, however, that "There is... a Tocquevillian mind-set that is consistently helpful" (190) when it comes to thinking about transitional effects and equilibrium effects, including the challenge of knowing which are which.

Another aspect that I will not develop here is Elster's conviction that Recollections is more than just anecdote and caricature, but offers a "psychology of revolutionary action" (151) that he says is also one of the hallmarks of The Ancien Régime and the Revolution. He praises that late unfinished work in his last paragraph as perhaps "the most theoretically informed historical analysis ever written" (191). Elster backs this up with an impressive list of what he says one can learn about from $A R$ :

Among the themes of this work are the "Tocqueville paradox," pluralistic ignorance, the dangers of concession or moderate repression and the superiority of preemptive measures, the causes and effects of emotions such as envy and hate, and the inevitable and inevitably futile attempt to harness revolutionary forces to partisan ends. (191)

These are some of the causal mechanisms that Elster says have not been taken into account as much as they could be, especially in rapidly changing parts of the globe such as Eastern Europe (190). He suggests that a more open-minded reading or rereading of Tocqueville would allow one to get a better grip on what those mechanisms are and how they work, or might work, case by case, since the Tocquevillian mind 
knows that "results may vary" and "past performance is not necessarily indicative of future results." 131

\section{Jean-Michel Heimonet, Tocqueville et le devenir de la démocratie: la perversion de l'idéal (1999, 397 pages)}

Jean-Michel Heimonet is the author of eleven books published over a twenty-year period (1986-2007) by smaller but thoroughly respectable presses. In 1999, after having devoted years of teaching, research, and writing to topics often lumped together under the heading "French theory," he turned his attention to the honorary American that some Frenchmen love to hate, and came out with a big book on Tocqueville. ${ }^{132}$ He has followed that up with three shorter essai books that all explicitly make use of Tocqueville as an important guide. ${ }^{133}$ Heimonet's other "tutelary deities"-comparable I'm suggesting to Tocqueville's daily exercise with Pascal, Montesquieu, and Rousseau - are Georges Bataille (1897-1962, especially the writings devoted to evil and the sacred) and Albert Camus (1913-1960, especially L'Homme révolté, 1951). ${ }^{134}$ As far as I know, none of Heimonet's books have been translated, and none of his fellow Tocqueville enthusiasts seem to have read him-not Rahe, whose fifty pages of footnotes crammed with book titles testify to his having read just about everything on Tocqueville that's out there, and not Antoine, despite the fact that one of her central themes, religion, is also of prime importance for Heimonet. And yet his books are all in print and as easy to procure as anyone else's. The website goodreads.com lists no reader reviews, and under the heading "Jean-Michel's Fans" are the dispiriting words: "None yet." How could Heimonet's Tocqueville book have made no friends or enemies in all this time? Simple oversight? Willful neglect? Malicious intent? It's hard to say.

The silence or silent treatment in response to what Heimonet has written about Tocqueville recalls the modern death sentence that Tocqueville says falls on the writer who dares to venture beyond the formidable barrier around thought erected by the omnipotent majority in today's democratic republics.

...You will remain among men, but you will forfeit your rights to humanity. When you approach your fellow creatures, they 
will shun you as one who is impure. And even those who believe in your innocence will abandon you, lest they, too, be shunned in turn. Go in peace, I will not take your life, but the life I leave you with is worse than death. (G294)

I don't want to exaggerate. There are some book reviews only a click away online, but very few on the four Tocqueville books. And presumably Professor Heimonet has not been "deactivated" from the Catholic University of America, where, according to the school's website, he holds the position of "Ordinary Professor of French" and in that capacity presumably still goes to faculty meetings, teaches, holds office hours, and grades papers, just like any other humanities professor in America.

Could there be something offensive or upsetting in his writings that would cause the majority of professional Tocqueville scholars to shun him? Is he maybe a silenced "whistle-blower"? Or is it perhaps that his work on Tocqueville is so derivative, amateurish, or off-base ("hors sujet") as to be not worth reading let alone making use of or quoting from? The last hypothesis seems impossible since Heimonet's interest in religion (and the sacred) clearly overlaps with Tocqueville, for whom, as everybody agrees, religion occupies a central place as the spiritual stuff within democratic societies that makes democratic man care about the public sphere and work on meaningful group projects that in turn affirm and strengthen community spirit. ${ }^{135}$ Religion also keeps the demolander from acting on the temptation to abandon civilization and simply strike out for the territory like the carefree boy Huckleberry Finn.

Secondly, there's nothing amateurish in the sense of sloppy or slapdash about Heimonet's books. There is only the amateurism that he himself admits to on the first page: coming to Tocqueville belatedly with the inexperience but also the fresh enthusiasm of an outsider. The "tolle lege" story he tells on the first page-rereading Tocqueville after living as a Frenchman in America for fifteen years, still trying to make sense of it all-is as believable and endearing in its own way as Elster's story or that of any other close encounter whose mix of intrigue and mystery makes a big impression.

Could one say Heimonet is derivative in the sense of being a copycat or lazily following the lead of others? He is clearly indebted to Eduardo Nolla's edition of Democracy in America like a lot of other readers and has 
learned things from Claude Lefort. ${ }^{136} \mathrm{He}$ is also familiar with the work of Furet, Mélonio, Gauchet, and Manent. But he specifically marks disagreements he has with the last two about the status of religion in Tocqueville's writings (against Manent, pp. 273-275; against Gauchet, pp. 326-330). Nor is it likely he derived his views from the work of Agnès Antoine, since he published his book on religion and citizenship four years before hers came out; and he probably has had little contact with her given the distance between the academic worlds of Paris and Washington, D.C. If anything, there is a certain sui generis, "my way" quality to Heimonet's Tocqueville books. They put Democracy in America into new constellations with the writings of authors that I dare say had never before been associated with him, notably Bataille, Barthes, and Camus. Besides the use of these stars from the world of French theory, which strikes me as motivated and instructive and not forced or fraudulent, Heimonet also makes use of a broad literary background (familiarity with Orwell, Huxley, Popper, German idealism and romanticism) and his knowledge of current events and the commentators that surround them (Barber, Mailer, Soros, Sunstein).

Before 9/11 and the ensuing resurrection of Orwell's “Two Minutes Hate" strategy on ideologically polarized American radio and TV shows over the last decade, not as many people were quoting Benjamin Barber or Cass Sunstein, and certainly not in books about Tocqueville. ${ }^{137}$ The use of these contemporary cultural critics becomes more prominent in Heimonet's three smaller Tocqueville \& Co. books. But in all four there is a strikingly original back and forth movement between the here/now of our terror-stricken modern societies and the there/then of the first half the nineteenth century in America and Europe that seems to most of us now like ancient history.

Along the time line of the last 150 years, at roughly the same eightyyear distance between "us" and "them," between our Internet age and the age of Jackson, Lincoln, Napoleon III, and Tocqueville, lies the disturbing decade of the 1930s. This decade, I am claiming, is what now separates our modernity from the "Antiquity" of Tocqueville's day and all that came before him. ${ }^{138}$ Our own time, interestingly, is often compared to the 1930s - it's a decade that haunts us - and it was also around the centenary of Democracy in America, in 1935, that Tocqueville first began to be 
"rediscovered." The 1930s is an important decade in the lives of Forster, Huxley, and Orwell, who will be discussed later, and in the career of Georges Bataille (1897-1962), whose writings are of crucial importance for Heimonet. He stands as a hybrid, transitional figure on the borderline between the new anciens (the pre-1914, pre-1930s world) and the new modernes (the Internet age), just as Tocqueville stood or floated-along with his countrymen-between the Old Regime and a new age still struggling to come into existence as he put it.

The title (in English) of Heimonet's first Tocqueville book-Tocqueville and the Becoming of Democracy: The Perversion of the Ideal-gets across two ideas. First, that it is going to be about Tocqueville's vision of democracy and how it might develop by its own means (or lack of means, incapacity, vulnerability), its own becoming that grows out of its being by its agency. That notion of becoming must be important to Heimonet, because otherwise the first part of the title could simply have been Tocqueville et l'avenir de la démocratie (Tocqueville and the Future of Democracy), which suggests a mere inventory of "forces" in the most general indeterminate sense. The second part of the title after the colon, The Perversion of the Ideal, names the low distortion or degradation from the once high élan of democracy's becoming that had been boldly launched by the Puritan idea/l, namely that a religious spirit and a spirit of freedom could and ought to be complementary and mutually reinforcing. This is the story that Heimonet understands to be the main thrust of the opening chapters of Democracy in America, and it is the falling off from the grandeur of this ideal to the sterility and vulgarity of small, overly private concerns that Tocqueville worries about for the rest of DA I and all of DA II-and rightly in Heimonet's view. Hence the need to insist on the example set by religion, which serves a double role: (1) it lubricates the wheels of democracy by encouraging cohesiveness and dynamism; (2) it directs that energy (or at least a portion of it) to higher projects and goals (such as passions and powers) beyond the most primary needs for basic survival: food, shelter, clothing, and sex. It even reinvents the notion of basic needs and inserts the religious, the sacred among them ("L'âme a des besoins qu'il faut satisfaire"- "the soul has needs that must be satisfied," DA II, 2, 12, 169). For Heimonet, it is an important moment later in DA II when Tocqueville declares that faith is the norm within human 
existence and incredulity is the accident or aberration: "L'incredulité est un accident, la foi seule est l'état permanent de l'humanité" (DA II, 2, 9, 403). Here Heimonet understands Tocqueville to be claiming a status for religious faith — which will be lived through acts of experiencing the sacred-that is very close to Bataille's affirmation one hundred years later of man's primal need for the sacred.

What Bataille contributes to Heimonet's reading of Tocqueville is the insight that the perversion of the ideal, the desecration of the grandeur by the low, the dirty, the vulgar, is necessary to establish the very notion of the ideal, the high, the transcendent. And therefore religion's role is not only to encourage cohesiveness but to also permit, and even incite, transgression, going against the grain, being an annoying irritant; for example, to the majority and its mours (its beliefs, routines, and values). The religieux plays this paradoxical double role of being the shepherd of the flock of co-believers, but also standing outside the "flock" of civil society, and thereby reminding everyone that there is an outside, and calling the parishioners to contemplate it while yet not dissolving the bonds that constitute the order of church and state (e.g., our ties to family, friends, employers, clubs, governors, and the law). This outside/inside double status is the model that Tocqueville, Bataille, and Heimonet (and long before them, John Calvin, John Knox, and Cotton Mather, for example) incarnate as writers and theorists. Theirs are quasi-priestly services in modern society comparable to the work of shamans and medicine men in earlier civilizations.

Bataille was a librarian and an author of some provocative stories and essays. He was a smuggler or passeur, both within a community and between a community and the transgressive outside of that community. His transgressions, going too far-like Don Giovanni, say, or Dimmsdale or Hester Prynne-were also a nourishment of the community, food that necessarily must come from some outside if it is to nourish and keep the community from turning in hungry stagnant circles. Via the example of Bataille, Heimonet reminds us that Tocqueville, like Adam Ferguson, Gibbon, and other general commentators of world civilization, insisted on the importance of invention and innovation, which explains Tocqueville's allegorical use of China as a negative example of traps to avoid; his scolding assessment of his own countrymen's disorientation 
and improductivity; and his warnings about America's potential for perversion and degradation-paradoxically because there has not been enough perversion (i.e., transgression-call it "Pussy Riot"139) of the enlivening kind that would nourish. Thoreau, a classics major of aristocratic bearing, was a good example of someone who experienced the sacred, lived sacredly, and nourished his community through the act of being outside and coming back and producing Walden (1854), the testimony of his disobedient transgression outside the community and an immense gift.

Reading Tocqueville and Bataille together, as Heimonet invites us to do, highlights the importance of certain remarks of Tocqueville that we had not fully measured. For example, when he witnesses the Fourth of July celebration and remarks on that solemn, spiritual atmosphere. What's going on there in Albany? Tocqueville realizes he is in the presence of the sacred and that in fact democracy in certain circumstances brings individuals a type of ecstatic, religious experience. But there should not be career politicians as there are career religieux in their various orders. It would be better if everyone rotated in and out of these quasi-priestly civilian roles, nourishing themselves and their community in turns, like at a potluck supper. What matters is belief in the religious experience, the sacred, and that can happen in many democratic offices, such as jury duty, serving on a community board or committee, or serving in the police, fire brigade, militia, or when voting - because in those roles one is signifying the community, in and outside the community at the same time, connected and the connection, the agent and the acted on. In those passing moments of communion (paradoxical because they consist in being in an oblique semidetached status vis-à-vis the community) one feels particularly alive, charged, meaningful. One's life and life in general feels important, validated, and one is at the source of that validation, not God, but godlike in the sense of creating, doing, making as God is said to be able to do.

Along the way Heimonet makes many worthwhile observations. For example, that Tocqueville's method is Socratic and not magistral, that he is his own midwife and wants to be a midwife for the thought of the reader, not the master, not the grand arrogant father as Guizot was and perhaps his own father Hervé as well (59). Second, that Tocqueville's 
method is itself democratic-open, free, disinterested inquiry, ready to look at as many sides as can be identified for inspection and weighing (83). Third, that life is the goal of democracy, just as truth is the goal of science and beauty is the goal of art (83). Fourth, that individualism, materialism, and nowism only become problematic for democracy when they stop being perverse (i.e., transgressive) but become a banal normbecause then they are not even in fact themselves: individualism flips into a simulacrum of individualism that is really just another conformity (to the uniform-e.g., having it "your way" composed from a pre-set menu of choices); materialism and shopping become sacred; the now is worshipped as though it were transcendent outside of time (slow-motion cinema, such as the plastic bag scene in the film "American Beauty," is often used to suggest this idea).

Reading Tocqueville and Bataille together lets one better understand how Tocqueville could be opposed to excess individualism and yet favor free individuals; i.e., a defender of an individual's right to liberté d'intelligence, liberty of action, initiation, invention, including the pursuit of eccentric or geeky (but generally law-abiding) minority pleasures such as studying Greek and Latin, for example. Tocqueville realizes that the spirit in "community spirit" is the gift that each individual gives as a sacrifice of his own energy for the sake (sacredness) of the group-it's a don, a free gift. But the community can only benefit from that energy if they themselves are free gifts, if they are not constrained, not duty-bound. The mistake of the Puritans was perhaps to have forgotten this freely given quality of each individual's participation. Voting must not be made compulsory for this reason. That turns the gift of voting into a due, a duty, and perverts its sacred dimension-something that we can perhaps only clearly appreciate when a country (Australia, Brazil, etc.) imposes mandatory voting. ${ }^{140}$

The problem with despotism, says Heimonet, is that it's "asymbolique," which is a fancy way of saying that it is sterile because it has no project, it is throwing nothing together, making no meaning, and therefore obstructing man's nature which is precisely to make meaning ${ }^{141}$ (123). Politics, Tocqueville realized, is one material form of an inner psychic need of the mental life not unlike the circular processes of toddler's play 
or experimental science: a continuous contest of problem solving by making projects and seeing them through to fruition.

So why is the transgressive writer punished by the omnipotent majority? It would be surprising if Heimonet did not comment on "the power that the majority in America exerts over thought," ${ }^{142}$ which he seems to know so intimately. The reason is because the despotic majority cannot tolerate that its project be questioned, doubted, competed with by an alternate project, an alternative vision. It wants more than to be right (which would imply that there's a possibility of being wrong, an outside); it wants "to go without saying," "aller de soi," to be the way it isi.e., immanence-not just the unique thought (la pensée unique), but beyond thinking. In other words, The Truth. To achieve this total mastery, it will exert overwhelming force when necessary against the slightest signs of resistance. It manifests itself in countless everyday situations as the immense pressure of the collective mind over the intelligence of each individual ("la pression immense de l'esprit de tous sur l'intelligence de chacun,” DA II, 18, G491).

Heimonet remarks on the moments when Tocqueville seems to despair of finding anything sacred or high in America, any product of a spirit of creative, "manly" liberty. Such as on page 149 where he quotes the Norman aristocrat's lament: "Il n'existe pas de genie littéraire sans liberté d'esprit, et il n'y a pas de liberté d'esprit en Amérique." ${ }^{143} \mathrm{He}$ is less mindful of other moments (such as DA II, 1, 9-10) where Tocqueville says that while for now there is no American Pascal (see DA II, 56), that sort of extraordinary genius may emerge eventually, because Americans have set up so many free institutions where they are able to exercise and give expression to an esprit de liberté: social clubs, libraries, schools, jury duty, and later liberal arts colleges and research universities, museums, parks, and vast wilderness and urban reserves. In all these places the democrat learns, in his bones, that liberty is something sacred- "chose sainte," (DA II, 1, 2, 19).

Like Tocqueville again, Heimonet wants to balance his despair with hope. He wants to insist on the "nature preventive de notre analyse" (155). In other words, like the ghost's lecture to Scrooge, he's not saying what will happen, but what could happen if certain steps are not taken-certain counterbalancing reforms. Heimonet seems to trust in Tocqueville's 
idea that democracy contains within it the cure for what ails it. (Recall Elster's ten "pathologies of democratic government," 147-149.)

For example, there is the religieux, who, like the teacher, practices a profession that has both conservative and subversive dimensions: conservative because his memory and his literacy allow him to strengthen the connective tissue of the community; subversive because he leads, and while leading by definition he is not following, not consuming, not merely receiving the sense, the products made and delivered by others, but is taking the Promethean step of having an original relation to the world-as Emerson recommended he do-"building his own world," which is transgressive of the values of the group, but which is also necessary if the group is to avoid stagnating and turning in sterile circles. ${ }^{144}$ So there is at once tolerance and intolerance for the religieux, the teacher, the artist, and for the scientist who is researching and not merely applying the results of yesterday's research.

Reading Tocqueville and Bataille together, as Heimonet recommends we do, reveals why judging Tocqueville; i.e., deciding whether he is liberal or conservative, progressive or regressive, avant-garde or reactionary, attracts so much attention. That he could be both, that he has to be both if he is to be true to the high-grand - role that he set for himself, this is not easily accepted by those in different camps who need him to be one or the other. "Reactionary" for the revolutionary Left and therefore to be rejected. "Communitarian" (an epithet) and (overly) protective of the community's local prerogatives for a certain nationalist Right that may deploy the terrifying (and hence uniting) specter of soft despotism, as Rahe does, or else denounce localism as "populism" (another epithet) in order to get people to accept "aristocratic liberalism"; i.e., their brand of managed democracy that they'll name approvingly liberal republicanism or meritocracy... and impose confidently with one-size-fits-all expediency no matter how suffocating or ill-adapted in certain circumstances. ${ }^{145}$

Unlike Marx, says Heimonet, Tocqueville never gives priority to matter over spirit, nor does he dissociate the two, but views them instead as always co-dependent, the one requiring the other for its very knowledge of itself (165). Heimonet clarifies this interdependence via some instructive borrowing from an early essay by Roland Barthes in which the famous semiologist takes stock of the wider social significance of 
Ferdinand de Saussure's Course in General Linguistics (1916). ${ }^{146}$ Barthes points out that what Saussure did by shifting the focus of his discipline from diachronic to synchronic studies was to democratize it (374). In this view Saussurean linguistics becomes the scientific equivalent of the French Revolution in that it ends the dominance of the former regime that was predicated on vertical lineage and inherited meaning and puts in its place horizontal relations where signifiers, like citizens, are all égaux en droits, i.e., have equal rights, and jockey for their significance amid a network of other competing signifiers each with the interest of pursuing its project, making its meaning, asserting itself, its existence and its power to signify, to do things with that significance.

Heimonet repeats that he is not trying to be alarmist or elegiac when he draws attention to the perversion of the ideal (171). The perversion has to happen. We have maybe to lose our community spirit in order to reinvent and cherish it anew. A version of the fortunate fall. So while the perversion is bound to happen, equally necessary is the recovery or relève through meaning making. Heimonet is fond of repeating Camus's affirmation from the Introduction to L'Homme révolté, "Parler répare"Speaking repairs. The regrettable scenario in Heimonet's view would be unmanly cowardice, cowering and retiring, leaving the field to the polarized and complementary opponents-Jihad and McWorld-the two faces of terrorism: the one that swears by the annihilation of all meaning making by exterminating you, and the other by the annihilation of all meaning making by stuffing you with the "burgers" (meanings) they've already made and force you to consume. The one keeps you living in fear of being killed next; the other claims to nourish you, but not so you grow up to be big and strong, but instead so that you live forever dependently, having to receive all from McWorld or from "Dreamworks," the dream factory that saturates you with its images, its narratives, its software, leaving you little chance of creating anything on your own. It tolerates poets, geeks, and nerds, so long as they're "hacks" providing content, entering code under their orders and not competing with them independently.

Heimonet, like Tocqueville, points out problems and cruxes, acting as a warning sign, but does not presume to know a miracle cure. $\mathrm{He}$ offers hints about the kind of behaviors that might get one out of the quagmire, out of the predicament of triviality and sterility, the "informe,", 
the "autodéstruction," the "perversion" toward a grander future-which doesn't mean simply a restoration of Classics or the pre-democratic classical doctrine. Heimonet's is not a nostalgia-driven enterprise angling for any particular past; it's a call similar to Emerson's in his "American Scholar" essay to battle the "counterenlightenment" that democracy is prone to by lighting the lamps that have gone out, if necessary at the light of previous examples that can serve as sources of inspiration-such as Bataille or Camus or Tocqueville. ${ }^{147}$ Their revolt, their example, is what Heimonet calls us to pay attention to and admire for its bold transgressive qualities that went largely against received ideas, simplicity, the easy way out, and consensual thinking and behaving. Democracy, if it remains an open society, preserves the possibility of this revolt that can happen when democratic man realizes that he has allowed his own system to turn on him, on his freedom (of intelligence); and the revolt is at once this realization and the expression of a new launching or lighting, a "reboot" to start anew. While at the same time there must be a conservationminded desire to prevent "overkill" in the very gesture that clears a space for the new freedom to express itself, not to kill off others, their habitats, and their projects, which, on the horizontal playing field of democracy, have as much right to life, liberty, and the pursuit of happiness as the next person's. But there is no ducking contest which is the basis of true politics. Let there be competition but let it be fair competition that moderates the inevitable pride and violence that come with being the winner, restrains the impulse to humiliate and reject out of hand, and allows losers to play again another day.

Heimonet sees religion as Tocqueville's best bet as to how democratic ages might be able to keep democracy off the twin rocks of entropy and totalitarianism (182). Totalitarianism, despite disguising its sterility under a momentary period of intense efficient productivity as all move in the same direction (think Sputnik or Minitel), ultimately reveals and stumbles on its entropy. Tocqueville had in mind a certain sclerotic China, but there are plenty of other examples (the Soviet Union, North Korea), as well as sclerotic corporations that either redo or die (GM, IBM, Xerox), bureaucracy-heavy (and sometimes corrupt) NGOs and charities, unwieldy school systems and political parties, and of course bad marriages and stale friendships. 
Heimonet reiterates his essential message in different ways in the three shorter follow-up books. They dispense with the exegesis of Tocqueville accomplished in the first longer study and use what was learned there to illuminate and comment on various geopolitical events, social phenomena, and transitional effects that Heimonet's Tocqueville mind-set (which is also a Bataille mind-set) allows him to diagnose with verve and insight. Among these phenomena are (1) apathy; (2) hétérophobie, a distrust of others (autrui) and disbelief in Autrui (the transcendent); (3) a distrust (méfiance) that a contract culture exacerbates; (4) twin, complementary terrorisms, Jihad and McWorld, which, Heimonet stresses, are not opposed, as Barber claimed in his book title-the mission of both being to extend dehumanization and the prime tactic being visceral antiintellectualism ("anti-intellectualisme visceral") crushing the soul and man's capacity for sacred meaning making; (5) the power of the archaic to be revolutionary in archconservative, antirevolutionary times or, alternatively, to be conservative and therapeutic in revolutionary times of dislocation and dismantling.

Faith changes objects, it doesn't die ("la foi change d'objet, elle ne meurt point," DA I, 406). This claim is what leads Heimonet to insist that for Tocqueville it's not a specific past tradition that matters as much as vision, faith in a future project so as to avoid resignation ("démission") and renunciation of one's proper humanity. The proper goal is to conserve religion's role within a democracy, to unseat the false, abusive total sacralization of private interest, of mere things, of the accidental ephemeral I-me-mine-here-now.

\section{Sheldon S. Wolin, Tocqueville Between Two Worlds: The Making of a Political and Theoretical Life (2001, 650 pages)}

"Il faut un courage singulier pour ne pas succomber à la depression et continuer - au nom de quoi ? Pourtant je continue, dans mon obscurité: l'homme continue en moi, en passe par là"

"Je me détruis dans l'infinie possibilité de mes semblables, elle anéantit le sens de ce moi." (Georges Bataille, Oeuvres, $\mathrm{V}, 45-46,48)$ 
"It takes singular courage not to succumb to depression and to continue on-in the name of what? And yet I continue, in my obscurity: man continues through me, passes through there."

"I destroy myself in the infinite possibility of my fellow man, it annihilates the meaning of this me."

To get them in the same room, so to speak, I begin this presentation of Sheldon S. Wolin's Tocqueville book with an epigraph from Georges Bataille, as quoted by Jean-Michel Heimonet at the end of Chapter Twelve of one of his Tocqueville follow-up books, La Démocratie en mal d'altérité (2003). I don't claim complete understanding of these three sentences that I've translated as best I can into English. It would seem Bataille is asking the question that occurs to every writer-For whom do I write?-and roughly speaking his answer is: For the infinite possible uses of mankind, for other language-users like myself but beside and beyond myself, "mes semblables,"-from before Baudelaire to Heimonet and beyond. Bataille, I take it, is saying that writing involves self-sacrifice for others and an infinite other, or Other, if you like, whom we can never completely know or master but to whom we can make our meaning-full contribution, our gift, in language - if we manage to fend off depression and mutism. Ultimately, that may be the answer given by any writer, any artist, or any person who builds, transforms, or reinvents something. It is an answer at once true, or at least plausible, but so general, so banal perhaps, as to hardly seem interesting or worthy of our attention. So let's ask a more pointed question: What does Sheldon S. Wolin want, and who cares? Taking the second part of the question first, the short answer is Not as many people as you might expect given his stature, the praise he receives from academic colleagues, the importance of the subjects he treats (politics, democracy, America, the social), and the painstaking attention that characterizes all of his writing - all two thousand or so pages of it. ${ }^{148}$

Some facts about his Tocqueville book. The book was published in 2001, well before the bicentenary, but has still not been translated into French or any other language as far as I know. Among the six endorsements on the back cover, we're told that "Sheldon Wolin speaks with a master's voice," has "enormous intellectual energy and flair," and the book 
is "penetrating, thorough, and authoritative," "a work of supreme scholarship," and a "magisterial study of Tocqueville." I happen to agree with all those claims. In addition, an online merchant lists only praising declarations, fifteen in all, from diverse authorities, including one who calls the work "masterful" and another who claims "the strength of Wolin's monograph lies in his patient, close readings of Tocqueville's major works." But that same online merchant lists no customer reviews for the book. This fact may lead one to reread differently one of those back cover blurbs that calls the book "an arresting critique."-arresting how? Is it a treatment of Tocqueville that makes you stop and think, or is it a book that makes you stop, period? Here we're faced with another embarrassing case of unintended consequences it seems. Presumably, Wolin's goal is to reach out to ordinary people, the demos, and raise their consciousness, educate, guide, embolden, and empower them. ${ }^{149}$ It's his proper professional role as set down in Emerson's “The American Scholar" speech (1837). But he's manifestly not getting through — not to ordinary people, not to American intellectuals other than those who were paid to comment on his book, and not even to French Tocquevillians and democracy sympathizers whom one would expect to be enthusiastic allies. ${ }^{150}$ Why not?

One answer is that he doesn't always know how to talk to ordinary people in democratic times. It was a good idea to go for "the making of" narrative structure, because ordinary people like to have ideas told to them in the form of a story, especially a life story, plus it's easier to remember, just like when things are arranged in a tuneful song such as the letters of the alphabet. On the other hand, it was maybe a bad idea to make up new words for new ideas near the end of his story, whereas he could have simply followed Tocqueville's strategy (in DA II, 4) and described those new things without giving them names. Hearing what sounds an animal makes and seeing how it behaves is often more memorable than being told its name.

"Postdemocracy," for example, and in the follow-up books "fugitive democracy" and "inverted totalitarianism" are three important neologisms for Wolin in which he invests a lot of explanatory energy, but none of these notions has gained any traction with the general public, perhaps because all three go against strongly held positions. First, the temporal prefix post- would be offensive to millions of people who believe they are 
living in actual democracies with democratic forms of government and a democratic way of life, however flawed and fragile. The words posthuman and postmodern are similarly counterintuitive for most people who consider themselves human beings and modern, because alive, and so these name tags may only work as shibboleths among academic oligarchs. Second, democracy does not typically cower, flee, or hide, and therefore to be linked with the noun or adjective fugitive (the connotations of which are runaway slaves or convicts) doesn't compute for ordinary people. Finally, the word totalitarianism sounds scary and hyperbolic and makes no sense to a card-carrying Democrat living in a wide open, unpredictable world that includes wet T-shirt contests, the Internet, Tony Hawk, and Sheldon Wolin. Totalize that! As for the word inverted, the likely associations are gymnastics or other extreme sports, neither of which is doing Wolin's argument much good. Therefore, despite his overall pedagogical clarity, at crucial moments he goes for lame names that have no "stickiness" for ordinary people and on the contrary risk being a drag or a turnoff. ${ }^{151}$ This tone deafness is somewhat surprising coming from someone who lived in demotic California in the 1960s, but there it is. The French would call it déformation professionnelle-one of the disadvantages of an elite education and an overly insular professional life perhaps. ${ }^{152}$

A second explanation is that his "friends" in intellectual circles have not been as helpful as they might have been. The words magisterial, masterful, monumental, supreme, and masterpiece are the kiss of death in democratic times, as any reader of Tocqueville (DA II, 1) knows. ${ }^{153}$ Those words, decoded by the demos, are saying "forbidding," "over my head," "not for me," "I'm not worthy," "I'd turn back if I were you”- "stop." In a similar vein, being an intellectual "star" openly associated with elite institutions of higher learning (Berkeley, Princeton) risks harming instead of helping in a demoland where a combination of envy and resentment is directed toward anyone who thinks. Tocqueville never tires of reminding his reader that thinking presupposes having the time, energy, and desire to think and is therefore an activity that, in the mind of the ordinary demolander, places the thinker in a leisure class from which she may feel mostly cut off and toward which she may also feel either hostility or indifference. ${ }^{154}$ Anyone who has read Tocqueville knows that publishers 
who want to sell brainy books in democratic times would be better off not advertising the prestigious institutional affiliations of their authors or their diplomas, concours victories, or awards. ${ }^{155}$

Another hypothesis might be that the book is too long. But demolanders are not put off by big books. Look at The Da Vinci Code or the Harry Potter books. Is the book's subject matter-a hero moving between different worlds, acquiring special powers, witnessing battles between weak and strong filled with reversals of fortune-not engaging enough? But demolanders love those kinds of stories, just as they are regularly seduced by "making of" supplements to their favorite movies that take them "behind the scenes." So what is it? Why isn't Tocqueville Between Two Worlds a best seller?

Setting aside these marketing questions, we can take a step closer to the book itself and ask why Wolin cares about Tocqueville and about the importance his writings seem to have had over his long career. First, Wolin has an interest in origins and beginnings that is common to many researchers (Darwin, Heidegger, Said). Just as with Elster, for whom Tocqueville is the first social scientist, Wolin claims "Tocqueville" represents many firsts. It's the first time democracy is taken as the central focus of a political theory (59), the first time a living democracy's practical sustainability and not just its formal structure comes in for scrutiny, the first time someone advances any serious belief in that sustainability, and the first time a major theoretical voice also participates in his country's political life through elective office. Wolin is also convinced that Tocqueville "was among the first to sense that modernizing is potentially totalizing" (97) and therefore that society could and most likely would in the years ahead either be steered toward or away from unfree status, i.e., to more authoritarianism or to more liberty.

Following Hannah Arendt (1906-1975), the study of the genesis and genealogy of authoritarianism and totalitarianism was common during the Cold War, and it has been the central concern of many of Tocqueville's earlier and more recent readers, including Rahe and Heimonet. Wolin, who had just graduated from college at the beginning of the Cold War, has also written two follow-ups to his big Tocqueville book that focus on the dangers of "managed democracy," "postdemocracy," and "inverted totalitarianism." They are the second half of the new expanded 
version of Politics and Vision (2004) and Democracy Incorporated (2008). Wolin's concerns in these later studies build on his early encounter with Tocqueville; in a certain sense one could say they have been ghostwritten by Tocqueville under the shadow of the Cold War, by which I do not mean that they are derivative or outdated. ${ }^{156}$ Wolin's long professional career spans the revolutionary "sixties" and the neoconservative backlash that took shape with Ronald Reagan in the 1980s and on into the Internet age. Moving with the years as a scholar and a citizen between ancient and modern worlds - for example, between the turbulent times of mid-nineteenth-century America and Europe and/versus the problematic start to the third millennium-I can easily imagine Wolin being spurred on to write these two additional pieces before it was too late. They are shorter, more declarative, and somewhat testy books written with an urgent indocile tone. These are characteristics that Wolin shares with Heimonet, Rahe, Todd, and Le Strat and Pelletier (and with the post-1848 Tocqueville, one might add). Is the older theorist inclined to scramble a bit, thinking that time is running out, and not just his own?

In contrast, Wolin's Tocqueville book, like his early breakthrough book Politics and Vision (1960), has an aristocratic calm and patience that are similar to the tone set by Agnès Antoine or by the younger Tocqueville, especially in those longer, unhurried chapters of DA I. Time is not money, and money is no object for at least some scholars even in democratic times. ${ }^{157}$ Wolin takes more time to ask questions in the Tocqueville book, and they're mostly real open questions that stand out and genuinely draw in the reader, inviting his participation in the thought-journey that's taking place. In other words, they are not just send/reply placeholders, so-called rhetorical questions or leading questions that allow the master to display knowledge or opinions and catch a breath before barreling on with the demonstration. Here's an example taken at random from page 268 :

How could Tocqueville recommend American democracy to the world while acknowledging that slavery was so deeply embedded in American society that he doubted equality between the races would ever be realized? 
Compare that with this piece of pseudo-Socratic method on page 285 of Democracy Incorporated:

How can elite calculation promote demotic irrationality that then feeds elite miscalculation? How are elites able to manipulate the demos, shape it into an irrational electorate, and then capitalize on it? The answer to both of those questions is this:

The point I want to make is that in the Tocqueville book Wolin is more willing to be the midwife of the reader's own thoughts and his own-because the questions are more real and the answers less clearwhereas in Democracy Incorporated his thoughts are put forward with less doubt and more affirmation - take it or leave it. ${ }^{158}$

This turn toward the magisterial-the academy's version of the totalitarian state, let's be clear, where the professor, if he chooses, can play the great dictator, the benign despot, the clown, or any combination of personae-may already be under way in the last chapter of the Tocqueville book, "Postdemocracy" (561-572). 159 There, less than two pages from the end, Wolin asks this question:

... If, as Tocqueville believed, self-government would be the crucial loss, how might that loss be concealed or, better, sublimated so that it appears to be flourishing? If despotism signifies, at the minimum, the destruction of the political in its modern form, we need to ask, What was that form? The answer is not obscure.

I regret that the answer is not more obscure or open for Wolin, just as I regret that he talks about the political in the past tense ("What was that form?"), as though it were already gone for Tocqueville and perhaps for us. This choice of the past tense leaves him no alternative, it seems, but to sign off with a final bitter declarative: "Democracy is perpetuated as philanthropic gesture, contemptuously institutionalized as welfare, and denigrated as populism" (572). Note how the ternary rhythm gives the list an air of exhaustivity — that's all, folks! How depressing.

Wolin might have made better use of this scorn and mourn technique by following it with a repetition of the real question he asked at the end of the paragraph just cited (570), like this: 
Currently, democracy is perpetuated as philanthropic gesture, contemptuously institutionalized as welfare, and denigrated as populism. Who tomorrow will control the meanings of democracy and, thereby, its fate?

Not only would this ending have been more in the spirit of Tocqueville's own interrogative mood at the conclusion of DA I and II, but it would have left the reader with a real challenge, worthy of his full attention and intelligence, because the answer is obscure. ${ }^{160}$ One of the reasons it's obscure is that one cannot even be sure that it's only a person or group - a "who"- that will control the meanings of democracy.

If Barthes, following Saussure, is right when he says that democracy is structured like a language, well, then, that means no one of us is going to totally decide on the meaning of democracy and its fate any more than Lewis Carroll's Humpty Dumpty decides on the meaning of individual words. The meanings of democracy tomorrow-like the meanings of friendship, marriage, love, liberty, equality, art, war, peace, death, life, and all the other big subjects that interest most of us (e.g., the Internet) - will be decided on by all of us (not each of us), and maybe by some things beyond anyone's will or control. ${ }^{161}$ Will some individuals or groups have more influence than others? Perhaps. But how could we ever predict in advance or measure with certainty afterward whose actions had done what? Who, for example, could predict that the wintry discontent and immolation of a Tunisian fruit seller would change the fate of the Arab world? And why did so many think, before this man's decision to light himself on fire, that certain peoples are fated to remain unfree? ${ }^{162}$

\section{$\phi$}

In the final analysis, however, whatever tactical flaws there might be take little away from the intrinsic merit of Wolin's truly grand, not just "fine," achievement. It would again be in Tocqueville's spirit of paradox to argue that those flaws are even "fortunate falls," since they are instructive and also humanize Wolin, thus bringing him closer to the rest of us more ordinary mortals. Demolanders may love perfectibility, but they secretly hate perfection and are openly hostile to a know-it-all. ${ }^{163}$ But all carping, 
paradox, and other inverted figures aside, Wolin's book is arguably the single greatest commentary on Tocqueville ever written.

What's so great about it? Many things in fact. First, there are "the patient, close readings of Tocqueville's major works" 164 and of some minor ones such as the prison essay, along with a keen sense of how one might think of them as a coherent ensemble. ${ }^{165}$ Second, there are substantive but not overwhelming doses of historical background information that allow the reader to appreciate the originality and boldness-the "material event"-of Tocqueville's achievements as a writer, as well as the complexity and compromises of his political life. Third, the book is uncommonly clear, well organized and motivated, and above all interesting. It is a page-turner (!) because Wolin succeeds in laying out a problem-Where ultimately does Tocqueville stand on democracy?-and relating it to a multitude of questions that engage us all: Where do I stand? where am I going? and my spouse? my kids? their school? my employer? my town? my country? my neighbors? These are large matters, and Wolin's Tocqueville book is a very fine guide to thinking about them. ${ }^{166}$

Taking these in reverse order we can give an example of each. We have already said how real questions addressed simultaneously to the reader and to the author are interest-creating, and we can add to that sympathy-creating: they place the reader in collaboration with the author on a shared journey of discovery. Here is another example taken from Wolin's discussion of the chapter in DA I that concerns the present and future of the three races that inhabit the United States, a chapter that he nominates as "at once the lengthiest, the most revealing, and the most enigmatic of the entire work" (266):

Was the curse of America not that of egalitarianism driven to extremes [producing in its wake extreme individualism, extreme materialism and extreme nowism], but something within the genius of a people whose vaunted pragmatism had allowed them to accept slavery into the original constitution and to trust thereafter in political compromisers such as Henry Clay, to put off indefinitely the day of reckoning?" (268) 
This is a real question because there is no sign that Wolin has a ready answer, and also because it contains within it many important subproblems. How can genius be a curse? Isn't God what Americans trust in, not political compromisers? Was God only a front all along, or did Americans lose their way and their nerve - trusting in Clay instead, what a name!as Heimonet and Rahe both suggest (each in his own way and each with different recommendations about how to recover and repair)?

Wolin's organizational skills are in evidence with his decision to opt for chapters of manageable length with multiple subdivisions that proceed chronologically through Tocqueville's life and times. He also offers a parallel supplement of bite-size epigraphs that are each referenced, thereby allowing the reader to follow up. Unreferenced epigraphs can be marveled at like sand dollars, but they risk projecting a haughty, marmoreal coldness - "Closed"- that may annoy or alienate the ordinary reader in democratic times.

Another sympathy-builder is Wolin's tactful placement of his own contribution within the history of the critical conversation on Tocqueville:

Alexis de Tocqueville made his political and theoretical mark in the world as the result of a voyage to America. Modern scholars have carefully traced every stage of his journey and others have reconstructed in detail the evolution of the manuscript of Tocqueville's classic. Little if any attention, however, has been given to what might be called the theoretical aura surrounding his journey. (34)

Without insulting or bragging, Wolin lets the student who wanders in late know she's welcome, that there is more day to dawn, and she can take part in the journey too.

Wolin's discussion of theory is a good example of an experienced professor's good judgment about how much of the backstory to give. For example, in this account of how theory and especially utopian theories derive from voyages of discovery:

Beginning early in the sixteenth century, the connection between theorizing and journeying acquired an additional dimension due to the voyages of discovery that brought Europeans into contact with vastly different cultures. The 
experience, or rather the reported experience, contributed to the unsettling of European assumptions about place, time, and the possible forms of human organization. As a result a quantum leap of the political imagination occurred. Mediaeval philosophers had no political utopias. Now, in contrast, Europeans could imagine themselves living differently, not necessarily by adopting exotic forms of life but by organizing in a consistent way the "rational" or "natural" possibilities immanent in their own societies.

The word "utopia" (literally "nowhere") was first coined by Thomas More to describe what he called "the best state of the commonwealth." (36-37)

This is smooth sailing for the ordinary reader, because there are few things a demolander likes more than to be told some facts that cover a lot of ground and order in his mind disparate elements that he had never connected before on his own. Wolin gets the job done efficiently here and then proceeds to move the reader along through Bacon, Locke, Machiavelli, Montesquieu, and others in a way that avoids the reefs of superficiality and pedantry and the negative side effects of "great men" fatigue.

Examples of Wolin's sharp textual attention include his two chapters (22 and 23) on Tocqueville's political career: "Souvenirs: Recollections In/tranquillity" and "Souvenirs: Socialism and the Crisis of the Political." By keeping the title of Tocqueville's private political memoir as Souvenirs, the reader who knows both French and English can hear the word naming both memories and the signifying material tokens a traveler accumulates. In these two chapters Wolin demonstrates that while the revolutionary events of 1848 may not have been Tocqueville's finest hour when it came to defending the Republican and Christian value of "fraternité" (solidarity), his fears about socialism leading to an expansion of centralized State power, and thereby being a threat to his aristocratically tinged concept of the political as quintessentially local, had a certain validity. However it does also look as though Tocqueville was caught in a contradiction of praising popular sovereignty abroad while denying it at home.

A second careful demonstration takes place over the following two chapters devoted to The Old Regime and the Revolution. Especially 
valuable is Wolin's discussion of Tocqueville's investment in the "archaic" as a means to resist and perhaps check the will-to-level of the modern State. Wolin explains:

Usually the archaic refers to a practice or belief that has survived the time to which it "properly belongs." Most of Tocqueville's archaisms derived from the Old Regime, which had governed France before the Great Revolution. The principal archaisms in Tocqueville's theory were "feudalism," "aristocracy," and "political liberty." As an element in a theoretical strategy, archaism aims at unsettling the present, bringing it to a temporary pause, insisting that it historicize its self-understanding. But the present instinctively resists historicization. It wants nothing more than to interpret itself by itself, that is, by its own notions and categories, by its own self-confirming narrative. The intrusion [of the archaic] forces the present out of its self-contained hermeneutical circle. Archaism can accomplish this effect because, unlike the present, it has been stripped of its context. It confronts the present like some displaced refugee caught between times and without place. Precisely because it cannot represent the abandoned past to a present whose identity is staked on the death of the past, the archaic trails an odor of death, an unwelcome reminder to the present that change not only brings new things into the world but causes other things to languish and disappear. The archaic forces the modern into self-questioning, slowing the urge to totalize. While premodern societies fetishized the past and were in constant fear of losing it, modernizing societies seek to escape by fetishizing the future. (565-566)

This is well put, but it must be remembered that this is Tocqueville's hopeful vision/version that Wolin is mimicking. ${ }^{167}$ One may note the need to anthropomorphize "the past" and "the present" as signs of the strain to tell a coherent narrative. The truth, what may really take place, as Wolin goes on to say in the next pages (and seven years later in Chapter Seven, "The Dynamics of the Archaic," of Democracy Incorporated), is that two can play at that game; in other words, the force of the archaic is also 
available for retrofitting and collaborative redeployment by the State (aka Superpower, Wolin's name for the new entity that results from the merger of the political and the economic in later modernity). If that happens, the resistant, archaic Tocquevilles of the world can be made to fall or when necessary be tripped into self-caricature, or flattened into objects of unthinking worship or equally unthinking ridicule like Shakespeare's Polonius, Wilde's Canterville Ghost, or Ishiguro's butler in Remains of the Day (1989), or else be smashed like Winston Smith's precious paperweight in Orwell's $1984 .{ }^{168}$ Wolin summarizes the predicament this way:

The vulnerability of democracy-modernity is revealed in its drift toward self-caricature: the free but privatized individual turns out to be the jargon by which identity conceals from itself that it is identical and, as such, the condition of despotism rather than its polar opposite.

Thus democracy is poised to become for our times what aristocracy was for Tocqueville's, the archaic remains of a superceded past. Unlike Tocqueville's aristocracy, however, the passing of democracy, if that is what is happening, is not being experienced as loss, as entrance into a time of postdemocracy, but as freedom from an impossible obligation.

What worries Wolin, and what worried Tocqueville, is that we might all end up being thankful to sign over our liberty to Superpower-Phew, what a load off my mind! - instead of mourning or resisting its passing. This possibility, which Wolin spooks up with the "specter" metaphor ${ }^{169}$ in the title of his follow-up book, leads him to ask about three pages later the real question that I suggested might have more fittingly been placed at the very end. I cite it again this time with the contextualizing lead-in sentences that make it all the more understandable and engaging for the ordinary reader:

The modern political was expressed as the concept of popular sovereignty, the idea that the citizenry should rule. That idea, however, assumed a politically engaged citizenry capable of disinterestedness. Without that assumption, democracy becomes all-purpose, infinitely plastic, and the question 
becomes, Who controls the meanings of democracy and, thereby, its fate? (570)

As I've already said, if the goal is to "nurture the civic conscience of society" and thereby ordinary popular sovereignty and the real advantages that can come from a democratic regime, I don't think it's productive to scare the reader (or oneself) with the idea that an anthropomorphic Superpower is calling all the shots, any more than it would be useful or true to say that we are more or less all decultured hollow men living in solitary confinement under the surveillance of some Superwarden, like at the American prisons Tocqueville visited and perversely recommended imitating in his government report (see Wolin's Chapter Twenty, “The Penitentiary Temptation"). Those who agree will prefer to let the question hang in the air-Who controls the meanings of democracy and, thereby, its fate? - and recall the possible effect of the smallest "Yip" or "Yop," the serendipity of the Tocqueville Paradox, and the chance of unintended consequences. This is not a recommendation that we renounce deliberation and choice and let "invisible hands" or "forces" do all the work. Perhaps better than anyone since Tocqueville himself, Wolin recalls for us the high stakes and the infinite responsibility of the task before us. The presence of the past, to use his phrase, and the whole arc of Wolin's project are clearly stated in the last paragraph of his Introduction:

A broad aim of this volume, then, is to use Tocqueville's ideas as (con)texts for reflecting upon the passage of liberal society from early to late modernity. There is an important sense in which Tocqueville was engaged in a lifelong task of retrieving a receding aristocratic past in order to counteract the new forms of despotism. One possible task for today's theorist is to ponder his example and to undertake the task of retrieving a receding democratic present in order to counteract even more novel forms of despotism. (9)

The task: to retrieve a receding democratic present. Keeping in mind Wolin's lesson that "theorist" means traveler and witness, it should be stressed that he is inviting each and every one of us to take up the task of retrieving democracy, and not merely an avant-garde of "brainworkers" (Orwell) as the elitist, professional-managerial-academic connotation of 
that word theorist might suggest. What the world needs now, says Wolin at the end of the expanded version of Politics and Vision (606), is a discordant, dissonant democracy_-because the former project of reconciliation between community and authority has been largely bulldozed by Superpower and won't be able to be salvaged until communities dig out from beneath the rubble and rebuild. "There's a place for us," sing Tony and Maria in two-part harmony during the height of the Cold War (West Side Story, 1957, 1961) — a democracy composed of public-spirited amateurs and professionals, ordinary and extraordinary individuals whose diverse talents, dispositions, and types of intelligence are aggregated in ways that welcome open debate, pursue projects of common interest, and avoid unrepairable mistakes.

\section{Notes}

73. The Dartmouth College library where I did research in 2008-2009 catalogued 189 books on Tocqueville.

74. See the reception history of Tocqueville's writings as told by Isaac Kramnick in his Introductions to both the Penguin and the Norton editions of Democracy in America. For information about the use of Tocqueville by Raymond Aron as a member of the Congress for Cultural Freedom, see Le Strat and Pelletier, 111-120. Accounts of the CIA-funded Congress for Cultural Freedom include Peter Coleman, The Liberal Conspiracy: The Congress for Cultural Freedom and the Struggle for the Mind of Postwar Europe (1989), Francis Stonor Saunders, The Cultural Cold War: The CIA and the World of Arts and Letters (2000), and Giles Scott-Smith, The Politics of Apolitical Culture: The Congress for Cultural Freedom and the Political Economy of American Hegemony 1945-1955 (2001).

75. See Christopher Newfield, Unmaking the Public University: The Forty-Year Assault on the Middle Class (Cambridge, MA: Harvard University Press, 2008), especially “Inventing PC: The War on Equality," 50-122.

76. In 2007, the share of total income going to the top $1 \%$ of American earners was $23.5 \%$ compared to $8.9 \%$ in 1976 . See Robert H. Frank, "Income Inequality: Too Big to Ignore," New York Times, October 16, 2010. See also Frank Rich, "Who Will Stand up to the Super-rich?" New York Times, November 13, 2010; and Joseph E. Stiglitz, "Of the 1\%, by the 1\%, for the 1\%," Vanity Fair, May 2011. See also Joseph E. Stiglitz's critical overview, The Price of Inequality: How Today's Divided Society Endangers Our Future (New York: Norton, 2012). 
77. For three tales of inequality in America, see Thomas B. Edsall's study from the post-Reaganomics dawn of the Internet age, The New Politics of Inequality (1984), and the more recent studies of Michael J. Thompson, The Politics of Inequality: A Political History of the Idea of Economic Inequality in America (2007), and Paul Krugman, The Conscience of a Liberal (2007, 2009). Edsall's concerns about inequality and austerity in his recent book The Age of Austerity: How Scarcity Will Remake American Politics (New York: Random House/Anchor, 2012) overlap those of the economist Robert J. Gordon. See Edsall's assessment of Gordon's predictions about overall slower growth in the years ahead and the aggravating effect of higher inequality, "No More Industrial Revolutions?” New York Times, October 15, 2012.

78. Charles Sellers, The Market Revolution: Jacksonian America, 1815-1846 (Oxford: Oxford University Press, 1991).

79. Daniel Walker Howe, What Hath God Wrought: The Transformation of America, 1815-1848 (Oxford: Oxford University Press, 2007).

80. “Tocqueville Retrouvé” [Tocqueville Rediscovered], an essay by Raymond Aron, appeared in the inaugural issue of The Tocqueville Review / La Revue Tocqueville 1:1 (Fall 1979): 8-23. As the article attests, this rediscovery was more wish than fact in 1979. However the dream had come true, sort of, by 2004 when Serge Audier published an adaptation of his doctoral thesis entitled Tocqueville Retrouvé: Genèse et enjeux du renouveau tocquevillien français (Paris: Vrin/EHESS, 2004).

81. Francis Fukuyama did not disappear however, and his latest book, The Origins of Political Order (New York: Farrar, Straus and Giroux, 2011), has intriguing Tocquevillian traits, most notably the singling out of religion as a catalyst of political development and as a defender of individual property rights and the rule of law.

82. Martha Nussbaum, The Clash Within: Democracy, Religious Violence, and India's Future (Cambridge, MA: Harvard University Press, 2007). One of the main themes and driving forces of all Tocqueville's writings, especially Democracy in America and the later Old Regime and the Revolution, is a "clash of civilizations" - call it aristocratic mores versus democratic mores. And if Tocqueville was able to report on that "culture shock" with so much clarity and clairvoyance, it is in part because he grappled endlessly with his own "clash within," especially the homeless feeling of living on "between two worlds," cut off from one (past) civilization and not belonging to any other because none yet existed. See Tocqueville's self-portrait as an impartial witness in the letter to his translator Reeve, March 22, 1837, quoted and discussed in Wolin 2001, 87-88.

83. These texts are available in the Norton edition of Democracy in America. 
84. J. P. Mayer, Prophet of the Mass Age: A Study of Count Alexis de Tocqueville (London: J. M. Dent, 1939). German born Jacob-Peter Mayer (1903-1992) was chief editor of Tocqueville's Oeuvres Complètes and prepared many single-volume editions of his works. He also founded the De Tocqueville Centre at Reading University. George W. Pierson, Tocqueville and Beaumont in America (1938). Phillips Bradley contributed notes, a bibliography, and an Introduction to the popular 1945 Knopf edition of Democracy in America (Reeve translation with revisions by Francis Bowen), which is still in print from Random House/Vintage (1990).

85. See David Riesman, The Lonely Crowd (1950); Max Lerner, America as a Civilization: Life and Thought in the United States Today (1957); Seymour Martin Lipset, Political Man: The Social Bases of Politics (1960); Raymond Aron, L'Opium des intellectuals (1955) / The Opium of the Intellectuals (1957).

86. See the bibliography for selected works by these authors.

87. France's concours system is unfamiliar to most Americans, nor is it well understood by the French. Symptomatically, there is no "Que sais-je?" pocket encyclopedia volume or other general study devoted to the history and rationale of concours, only how-to manuals for specific competitions. What's important to know is that a concours puts candidates in competition with each other and selects the top ones based on how many openings are available in a given area in a given year. Therefore, it is more than just an exam that only seeks to measure what you know, and it is also more than a degree since the latter, although usually a student's first goal, is a means to another end (a job), and so forth. A concours is a job recruitment mechanism that instantly confers a significant social promotion and a keen sense of entitlement. To overlook this is to ignore how France bestows some aristocratic-like privileges on over a million of its citizens, who, as one might expect, wield considerable power when "mobilized." In her New Yorker magazine profile on Elizabeth Badinter's “contrarian feminism” ("Against Nature," July 25, 2011, 44-55), Jane Kramer errs when she writes, "By 1972, she had passed the exams for an agrégation in philosophy-the country's advanced pre-doctoral degree" (48). The agrégation in philosophy is not a degree, nor is it a prerequisite for doctoral work. The agrégation is a highly prestigious (because intrinsically difficult and highly selective) concours. Winning that prize, and the job security that comes with it, alters one's whole career and outlook on life. To my knowledge no enterprising latter-day Tocqueville has yet written a sociological study of the impact of concours on, for example, Mai '68, or the other stormy and stressed out periods of French history. Tocqueville however provides the best starting point; see DA II, 3, 20: “On Place-Hunting in Certain Democracies,” DA II, 307-308, G745-746.

88. Examples of the latter would be Gerald Bevan's recent translation of The Ancien Régime and the Revolution (London: Penguin, 2008) and the slim volume Sur le pauperisme (Paris: Allia, 1999) that reprints a Tocqueville 
essay from 1835. See the bibliography for the titles by authors mentioned in this paragraph.

89. See, for example, Jean Baudrillard, America (1989); Bernard Henri-Lévy, American Vertigo (2006); Peter Carey, Parrot and Olivier in America (2009).

90. The phrase "justice, not charity" is associated with the teachings of Reverend William Sloane Coffin, Jr. (1924-2006). See The Collected Sermons of William Sloane Coffin: The Riverside Years, Volume 1 (Louisville: Westminster John Knox Press, 2008), 178.

91. In fact it's even more complex. To review: in the passage quoted above, Kramer gives an example of what she calls Badinter's "contrarian feminism"; and contrarian or against-the-grain thinking, if that's what this is, is certainly a point of similarity with Tocqueville. What is Badinter's thought? She claims that members of the group that benefits the most from the unequal distribution of a particular good are "often" the ones who tolerate (i.e., accept, put up with, stand for) unequal distribution the least. So for her, those who have the most money, say, are often the most eager to have all money seized and redistributed equally to everyone-like starting over in a game of Monopoly, is that it? And she claims (with no page reference) that Tocqueville also makes this claim? But that sounds like "socialism," which Tocqueville was strongly opposed to. Badinter may have the unusual billionaire Warren "tax me more" Buffett in mind, but how many others like him are out there? And where is there? Is Badinter talking about people living under an aristocracy, in an old democracy like America, or in a country perhaps transitioning toward democracy? The answer matters a lot to Tocqueville, because he believes that living arrangements, and the prospect (high or low) that they can change or be changed, will alter people's beliefs, present behavior, and plans for the future. The most relevant chapters on this topic in Democracy in America are II, 2, 3, "How Individualism Is More Pronounced at the End of a Revolution than at Any Other Time”; II, 3, 21, "Why Great Revolutions Will Become Rare"; and II, 3, 22, "Why Democratic Peoples Naturally Desire Peace and Democratic Armies Naturally Desire War." In a stable aristocracy, the local grandee may be more easily nudged into doing good works - charity — and thus alleviating some misery while leaving the inequality on which he depends intact. In a stable, mature democracy, the working citizen generally accepts when asked and at the last possible moment to pay the amount of tax that the majority of voters has decided he owes - an ideal of social justice having replaced charity in his mind: "From each according to his ability, to each according to his need," as Karl Marx recommended in 1875 long after Tocqueville had died. The democrat accepts that abilities and needs are unequal, because everybody is different. The socialist, Tocqueville feared, believes confidently and righteously in his ability to engineer those differences out of existence, and that the end (more equality) justifies the means (less individual liberty). The 
least tolerant of inequality, according to Tocqueville, are those individuals in a society transitioning toward greater equality of social conditions who have just begun to taste privileges that they had never known, and who have become intensely desirous for more, and deeply unsatisfied if they don't get it (G588-589). Followers of the Arab Spring take note.

92. See any online merchant for titles of Tocqueville and Tocqueville studies in other languages.

93. Full disclosure: I received no money or other incentives to include or exclude the work of any particular author. Specifically, I have never met or corresponded with any of the authors featured here except Emmanuel Todd, with whom I exchanged a handful of e-mails in 2003 in connection with my translation of his book Après l'Empire (Paris: Gallimard, 2002) / After the Empire (New York: Columbia University Press, 2003). He and I never discussed Tocqueville, though I would be pleased to do so, just as I would be pleased to meet and converse with anyone about Tocqueville, especially the authors of the texts discussed here. They have taught me a great deal, and I am infinitely indebted to them.

94. See Martin Rogoff, “Book Review, Leo Damrosch, Tocqueville's Discovery of America,” American Journal of Legal History 52:2 (April 2012): 214-217; James Wood, “Tocqueville in America: The Grand Journey Retraced and Reimagined,” New Yorker, May 17, 2010, 104-109.

95. The French Pléide edition (I, 340-352) contains a list of the hundreds of prepared questions Tocqueville was eager to ask. The legend started by Beaumont is that Tocqueville stayed up late every night writing up the answers he heard and his thoughts and impressions of each day's encounters.

96. Reading for Rhetoric, ed. Carline Shrodes, Clifford Josephson, and James R. Willson (New York: Macmillan, 1966).

97. Some of the most influential books of Pierre Bourdieu (1930-2002) are Les héritiers: Les étudiants et la culture (1964), La Reproduction: Éléments pour une théorie du système d'enseignement (1970, with Jean-Claude Passeron), La Distinction: Critique sociale du jugement (1979), and Homo academicus (1984). For a Bourdieu-inspired look at Anglo-American literature studies, see John Guillory, Cultural Capital: The Problem of Literary Canon Formation (1993).

98. Françoise Mélonio, Tocqueville and the French, trans. Beth G. Raps (Charlottesville: University of Virginia Press, 1998), 213.

99. For another longer reading of that signifier and the history of its many meanings, see Alain Laurent, Le Libéralisme américain: Histoire d'un détournement (Paris: Les Belles Lettres, 2006).

100. My definition of research is borrowed from Wayne Booth et al., The Craft of Research, 3rd edition (Chicago: University of Chicago Press, 2008). 
101. It is easy to imagine Rahe awaiting further confirmation of his diagnosis of a "French disease" and welcoming any bad news out of France (such as capital flows out of the country or wealthy citizens self-deporting to flee steep tax increases) in the wake of center-right Nicolas Sarkozy's defeat on May 6, 2012, and the victory of center-left François Hollande, who is France's first Socialist president since François Mitterrand (1981-1995). For another Schadenfreude-tinged profile of Nicolas Sarkozy and France in the run-up to the 2012 presidential election, see Philip Gourevitch, "No Exit: Can Nicolas Sarkozy-and France-Survive the European Crisis?" New Yorker, December 12, 2011, 46-61.

102. On the French historian and politician François Guizot (1787-1874), see Pierre Rosanvallon, Le Moment Guizot (Paris: Gallimard, 1985).

103. For a comparative study of the father-son relationship, see R. R. Palmer, ed., The Two Tocquevilles, Father and Son: Hervé and Alexis de Tocqueville on the Coming of the French Revolution (Princeton: Princeton University Press, 1987).

104. See Tocqueville's differentiating remarks in his Introductions to the first and twelfth editions of Democracy in America and the early chapters on the "configuration," "point de départ," and "état social" specific to North America.

105. On paranoia and politics, see Richard J. Hofstadter, “The Paranoid Style in American Politics," Harper's Magazine, November 1964, 77-86. This essay has received much attention in recent years. See George Packer, "Populism and Paranoia," New Yorker, March 24, 2009, and "More Paranoia," March 27, 2009. The Hofstadter essay is accessible here: <http://www.harpers.org/ archive/1964/11/0014706>. And there is a 2008 Random House/Vintage reissue with Foreword by Sean Wilentz.

106. See Tocqueville's comparison of life on the two banks of the Ohio River in Kentucky versus Ohio that evolves into a detailed comparison of life in slave states versus the free soil North: DA I, 2, 10, 459-480.

107. Worry about the soft despotism of an "imperial presidency" starting with the Franklin D. Roosevelt "administration" sparked the Twenty-second Amendment to the U.S. Constitution (enacted in 1951) establishing term limits - two four-year terms. Since then, similar allegations have fueled angry efforts to use the courts and Congress to undo many New Deal reforms perceived by Orwell- and Tocqueville-influenced conservatives as symptoms of the evil of "big government."

108. I translated this book for Columbia University Press in the first three months of 2003.

109. In the wake of the Arab Spring, Todd published a news analysis interview he gave under the title Allah n'y est pour rien (2011)_Allah has nothing to do with 
it. His most recent book, in collaboration with Hervé Le Bras, is L'Invention de la France: Atlas anthropologique et politique (Paris: Gallimard, 2012) -an update of their earlier 1981 publication entitled L'Invention de la France.

110. Mike Burry is one of the short sellers featured in Michael Lewis's bestseller The Big Short: Inside the Doomsday Machine (New York: Norton, 2010). For a summary, see Michael Lewis, "Betting on the Blind Side," Vanity Fair, April 2010.

111. See Thomas Friedman, "A Theory of Everything (Sort Of)," New York Times, August 13, 2011. Todd could be seen as a French version of Thomas Friedman, Amy Chua, or Malcolm Gladwell. Like these three, he spends considerable time thinking about big trends, the rise and fall of civilizations, and tipping points. For representative works of these three, see Thomas Friedman, Hot, Flat, and Crowded (2008); Amy Chua, Day of Empire: How Hyperpowers Rise to Global Dominance - and Why They Fall (2007); Malcolm Gladwell, The Tipping Point (2000).

112. "Au rythme où évolue actuellement la philosophie politique, les intellectuals de tradition démocratique vont bientôt regretter le tocquevillisme banal."

113. "Mais si Tocqueville a aujourd'hui plus d'héritiers que de contradicteurs, c'est aussi pour quelques thèses banales, dont celle d'une égalité menaçante pour la liberté, ou celle d'un individualisme qui tend à se contredire ellemême." This sentence ends with the footnote that refers the reader interested in knowing more about the "increasing power of tocquevillisme" to the "excellent book" by Claire Le Strat and Willy Pelletier, La Canonisation libérale de Tocqueville. Rahe also recommends this book $(337,54 \mathrm{n})$ "to get a sense of the sources of resistance in France to learning from Tocqueville”, i.e., as a further symptom of the harmful French disease Rahe has diagnosed.

114. "Il n'en a eu que plus de mérite d'avoir accepté, du bout des lèvres, l'inévitabilité de la démocratie" (85). The lips metaphor here is supposed to convey the idea of someone accepting something with resistance, as though it were an unpleasant food or medicine, like cod-liver oil, perhaps. In English the expression "while holding his nose" is perhaps more common. The more standard view is that Tocqueville did not resist the advent of greater equality, except during the revolutionary events of 1848 when he opposed what he considered to be socialist extremism, and he accepted the idea of popular sovereignty and expressed his preference for liberal democracy though, as I have argued, he was ready to accept democratic tyranny, socalled soft despotism, if the only alternative was old-fashioned "sticks and stones" tyranny.

115. “On n’apprend pas à lire pour être l'égal des autres, pour être un 'individu démocratique,' mais pour être un individu mieux formé intellectuellement” (86). 
116. Or be their own Descartes, as Tocqueville observes in the opening chapter to DA II, "De la méthode philosophique des Américains," G483: “America, then, is one of the countries in which Descartes is studied least but his precepts are respected most"-especially with the American's habit of relying "solely on the unaided effort of his own individual reason."

117. The phrase “force and fraud” comes from Thorstein Veblen's The Theory of the Leisure Class (1899), a serious parody of the West's tradition of grand theorizing about the history of civil society and man's alleged "progress."

118. Another example would be Joshua Mitchell's The Fragility of Freedom: Tocqueville on Religion, Democracy, and the American Future (Chicago: University of Chicago Press, 1995). The colon is absent on the cover but appears on the Library of Congress publication data page.

119. In these two excerpts from her Introduction and Conclusion one gets the drift of Antoine's singular project: Introduction, p. 7: "En ce début du XXIe siècle, ou pour le dire autrement, depuis la chute du mur de Berlin qui a mis fin symboliquement, au siècle précédant, la pensée de Tocqueville jouit tant en France qu'en Amérique d'un engouement général.” Conclusion, p. 350: "Contre ceux qui veulent poser les conditions de ce qu'il est permis d'espérer, [Tocqueville] essaie de préserver la possibilité d'espérer ce qui n'est pas encore permis." "Here at the beginning of the twenty-first century, or, to put it differently, since the fall of the Berlin Wall that symbolically put an end to the previous century, there is a general passion for Tocqueville's thought both in France and America. (...) Against those who want to set the conditions of what is permissible to hope for, [Tocqueville] tries to preserve the possibility of hoping for that which is not yet permitted."

120. For a second opinion, see the book review by Cheryl B. Welch in French Politics, Culture \& Society 23:2 (Summer 2005): 145-148. Welch is also the author of the monograph De Tocqueville (Oxford: Oxford University Press, 2001).

121. It is as though Antoine were saying, "No animals were harmed in the making of this book"-because she is the rock and not a fur trader. The painting is Fur Traders Descending the Missouri (1845) by George Caleb Bingham (New York: Metropolitan Museum).

122. The back cover states that Jon Elster (1940-) holds the Chair of Rationality and Social Sciences at the Collège de France. This is one of France's most prestigious institutions of learning, comparable to the Académie Française, to which Tocqueville was elected on December 23, 1841.

123. See the news article by Sheryl Gay Stolberg, "Shy U.S. Intellectual Created Playbook Used in a Revolution,” New York Times, February 16, 2011.

124. The concept of "unintended consequences," the idea that there are outcomes that are not the outcomes of purposeful action, is often said to have 
originated with Bernard Mandeville's Fable of the Bees: or, Private Vices, Publick Benefits $(1705,1714)$. An earlier source may have been the thought behind Christ's pronouncement "Father, forgive them, for they know not what they do" (Luke, 23:34 KJV). The concept gained wider circulation during the Scottish Enlightenment in the writings of Adam Smith (A Theory of Moral Sentiments, 1759; The Wealth of Nations, 1776) and in Adam Ferguson's An Essay on the History of Civil Society (1767). The notion received its modern name and scholarly attention in the twentieth century starting with the American sociologist Robert K. Merton in his essay "The Unanticipated Consequences of Social Action" (1936). Merton also developed related concepts, such as "the self-defeating prophecy" and "the self-fulfilling prophecy," that have become standard sociological tools. Elster's claim is that Tocqueville intuited and used many of these tools to understand social phenomena such as democracy in America and the French Revolution.

125. These include the blending and bending of real and ideal, life and literature. Perhaps more than other human species, demolanders carry out Nietzsche's call to live one's life as a work of art-with all the attendant thrills and agonies. On conflicts between the humanities and social sciences, see David A. Hollinger's book review of Bruce Mazlish's The Uncertain Sciences (New Haven: Yale University Press, 1998), "Running To and Fro," New York Times, May 23, 1999. See also Gary Gutting, "How Reliable are the Social Sciences?” New York Times, May 17, 2012; and Jim Manzi, Uncontrolled: The Surprising Payoff of Trial-and-Error for Business, Politics, and Society (New York: Basic Books, 2012).

126. It is plausible that Tocqueville's wide reading brought him into contact with the innovative theories of Pierre-Simon de Laplace (1749-1827) on statistics, probability, and Newtonian physics-especially the less technical versions that he wrote up in Exposition du système du monde (1796) and Essai philosophique sur les probabilités (1814). Raymond Boudon raises the possibility of this link in his discussion of Tocqueville's thoughts on necessity and chance (20-26). My point is that Tocqueville may have become attuned to the explanatory power of statistics applied to a given sphere of activity without being aware of the actual numbers themselves. He may also have been stirred by Laplace's famous relegation of God to the status of a "hypothesis." For a discussion of Laplace in the context of American pragmatism, see Chapter Eight, “The Law of Errors," in Louis Menand's The Metaphysical Club: A Story of Ideas in America (New York: Farrar, Straus and Giroux, 2001), 177-200.

127. Elster, 145. Elster does not mention The Wisdom of Crowds (2004) by James Surowiecki, but they've hit on the same phrase to explore similar questions about group intelligence and group decisions. See the Wikipedia entry "Wisdom of the Crowd" for additional bibliography. 
128. This discussion in $D A I, 2,5$, takes place in a subsection appropriately titled "On American Democracy's Power Over Itself”- “Du Pouvoir qu'exerce en général la démocratie américaine sur elle-même” (317-319). The "en général”generally, in general, i.e., not all the time-is lost in Goldhammer's translation and others. This is a pity since Tocqueville's point here is that democracy's mastery is not total, and it is able and willing to make nonfatal mistakes because it is a somewhat childlike regime that knows it learns best from trial and error. Remember Manzi's title, Uncontrolled: The Surprising Payoff of Trial-and-Error for Business, Politics, and Society.

129. See the useful Chronology in Goldhammer, especially pages 898-904.

130. Elster, 184. Talcott Parsons (1902-1979) was an influential American sociology professor at Harvard University from 1927 to 1973. Three of his major theoretical works are The Structure of Social Action (1937), The Social System (1951), and Toward a General Theory of Action (1951).

131. Google "Tocqueville" and you will find among the top-listed links Tocqueville.com, a New York-based asset management company, and Tocquevillefinance.fr, its French partner.

132. Heimonet's Tocqueville book is searchable at Google books.

133. La Démocratie en mal d'altérité: Masse et terreur, réflexions sur l'informe du pouvoir moderne (Paris: L'Harmattan, 2003); Les Deux faces du terrorisme et l'autodéstruction des sociétés ouvertes (Paris: Éditions Kimé, 2005); La Raison démocratique dans les limites du religieux: Terreur intellectuelle et l'âge postmoderne (Nantes: Éditions Cécile Defaut, 2007).

134. Three of Bataille's most influential texts are L'Expérience intérieure (1943), La Part maudite (1949), and L'Érotisme (1957).

135. For a recent study of the uniting and dividing forces behind religious beliefs, see Jonathan Haidt, The Righteous Mind: Why Good People Are Divided by Politics and Religion (New York: Pantheon, 2012). For an example of the French interest in the subject of care, see Fabienne Brugère, L'Éthique du "care" (Paris: PUF: Que sais-je?, 2011), as well as Brugère's meditation on revitalizing French democracy, Faut-il se révolter? (Paris: Bayard, 2012). Recent French interest in "care" and caring (about relationships especially, such as those fostered by democracy) has been partly inspired by the belated French discovery of the work of American feminist and ethicist Carol Gilligan, especially her groundbreaking study In a Different Voice (1982), which appeared in a French translation only recently as Une voix différente: Pour une éthique $d u$ care (Paris: Flammarion, 2008). Another classic study along these lines that exists in Italian but not in French translation is Robert Bellah et al., Habits of the Heart: Individualism and Commitment in American Life (Berkeley: University of California Press, 1985, 1996, 2008). See also Robert Bellah et al., The Good Society (1992). 
136. Claude Lefort (1924-2010), a French philosopher and political scientist, wrote a dozen books, the most well known being L'Invention démocratique (1981) in which he specified the crisis and chance of democracy to be that it is a "lieu vide" - an empty or open space. Heimonet summarizes it himself on page 174: "Or ce vide fait tout en un leur malheur et leur chance."

137. Among their many books, see Benjamin Barber, Jihad vs. McWorld: Terrorism's Challenge to Democracy (1995), Strong Democracy: Participatory Politics for a New Age (1984); Cass R. Sunstein, Democracy and the Problem of Free Speech (1993), Going to Extremes: How Like Minds Unite and Divide (2009).

138. Abraham Lincoln (1809-1865) was only four years younger than Tocqueville, Napoleon III (1808-1873) three years younger. Andrew Jackson (1767-1845) was five years older than Tocqueville's father, Hervé (1772-1856).

139. See the Wikipedia entry for the controversial Russian rock band "Pussy Riot."

140. See the Wikipedia entry "Compulsory Voting” for an outline of the arguments in favor and against and a list of countries that practice compulsory voting.

141. Veblen called this "the instinct of workmanship."

142. See DA I, 2, 7, 352-355; G292-295, "On the power that the majority in America exerts over thought."

143. DA I, 2, 7, 355, G295. See also DA I, 353, G293: "Je ne connais pas de pays où il règne, en général, moins d'indépendance d'esprit et de veritable liberté de discussion qu'en Amérique." [I know of no country where there is in general less independence of mind and true freedom of discussion than in America.] Note here again Tocqueville's use of en général, which has the effect of moderating his claim somewhat.

144. I am borrowing the terms subversive and conservative here to link up with the observations of the cultural critic Neil Postman (1931-2003) in two of his most well-known books, Teaching as a Subversive Activity (1969, with Charles Weingartner) and Teaching as a Conserving Activity (1979). His Wikipedia entry gives more bibliography and links, including one to a 1990 speech entitled "Informing Ourselves to Death" that has lost none of its relevance in the Internet Age.

145. An example in France that regularly divides "Left" and "Right" is the debate around the advisability of a "collège unique," i.e., a common curriculum policy for French middle schoolers that has existed since 1975. See the documents assembled here: <http://www.ladocumentationfrancaise. $\mathrm{fr} /$ dossiers/college-unique/index.shtml $>$ and these two comments by a collective, < http://www.millenaire3.com/uploads/tx_ressm3/ 
College_unique.pdf $>$, and by François Dubet, an outspoken defender of the "collège unique" policy and an opponent of early tracking: <http:// www.scienceshumaines.com/menace-sur-le-college-unique-rencontreavec-francois-dubet_fr_27203.html>. This debate (common core curriculum versus tracking; socialization versus individualization, etc.) is likely to heat up in the coming years, in France and elsewhere, as part of a general reexamination of the methods and aims of all schools in the global Internet Age.

146. For Heimonet's discussion of Barthes, see pages 23-24 and 373-377. See Roland Barthes, “Saussure, le signe, la démocratie” (1973), in L'Aventure sémiologique (Paris: Seuil / Points essais, 1985), 221-226.

147. See MLA president Russell Berman's 2011 call to resist the contemporary “counterenlightenment.” See DA II, 59, for Tocqueville's warning about the high price to be paid for allowing the "lights" to go out: "Si les lumières qui nous éclairent venaient jamais à s'éteindre...." Emerson also uses the familiar light metaphor in "The American Scholar" essay when discussing the proper use of books in dark "idle times": "But when the intervals of darkness come, as come they must,--when the sun is hid and the stars withdraw their shining,--we repair to the lamps which were kindled by their ray, to guide our steps to the East again where the dawn is" (The Portable Emerson, 57). For a contemporary example of this relighting of extinguished lamps, see Andrew Delbanco, College: What It Was, Is, and Should Be (Princeton: Princeton University Press, 2012).

148. Besides writing six hundred pages on Tocqueville, Sheldon S. Wolin (1922-) is the author of The Presence of the Past: Essays on the State and the Constitution (1989), Politics and Vision: Continuity and Innovation in Western Political Thought (1960, 2004 expanded edition), and Democracy Incorporated: Managed Democracy and the Specter of Inverted Totalitarianism (2008; 2010, with a new Preface by the author). The last two have been translated into both Spanish and Italian. His work has also been the subject of a volume of scholarly essays, Democracy and Vision: Sheldon Wolin and the Vicissitudes of the Political, ed. Aryeh Botwinick and William E. Connolley (Princeton: Princeton University Press, 2001).

149. Wolin has tried to broadcast his educational message about the need "to nurture the civic conscience of society" (Politics and Vision, 606) in many ways, including on YouTube; but extracts from his conversations with Bill Moyers, for example, have been viewed less than 10,000 times, despite Wolin's eloquence and the relevance of his topic.

150. None of the contributors in the volume dedicated to Wolin's work (Democracy and Vision) is French. Symmetrically, of the eight prominent contributors to an ostensibly inclusive well-informed volume of essays entitled Démocratie, dans quel état? (Paris: La Fabrique, 2009) only the two Americans, Wendy 
Brown and Kristin Ross, make use of Wolin. Wolin's early essay “Archaism and Modernity" (Tocqueville Review n. 7 [1985-1986]: 77-88) — a testimony to the long maturation of his ideas about Tocqueville (despite his near total absence from Politics and Vision) — was not included in the "best of" 25 th anniversary collection of that journal. His absence from some French Tocqueville books is to be expected, but it is somewhat surprising in the case of Antoine and Boudon, for example, who clearly are familiar with the work of some other American Tocqueville scholars. Rahe in his characteristic thoroughness notes the existence of Wolin's Tocqueville book, which he dubs "fine," but in the same sentence he slams Wolin for being "too wedded to the shibboleths of the 1960 s to be able to properly consider the present discontents in light of the Frenchman's analysis" $(339, \mathrm{n} 1)$ Rahe's comment would have been more useful to the reader if he had identified those "shibboleths" (i.e., code words that identify and unify a group) and if he had specified what individuals or groups are behind his own coded reference to "the present discontents." If Heimonet has read Wolin, with whom he has so much in common, both thematically and rhetorically, he is keeping it to himself-and vice versa.

151. A more felicitous Wolin creation is the term managed democracy, which has caught on, perhaps thanks to its slightly Orwellian oxymoronic quality. Managed democracy is the term used approvingly by Vladislav Surkov to describe Putin's Russia in two recent New Yorker articles. See David Remnick, "The Civil Archipelago: How Far Can the Resistance to Vladimir Putin Go?" New Yorker, December 19 \& 26, 2011, 95-108, especially page 107; Julia Ioffe, "The Master and Mikhail: Are Putin and Prokhorov Running for President against or with Each Other?” New Yorker, February 27, 2012, 40-45, page 41. "Managed democracy"- "a postmodern system that includes elements of autocracy, democracy, and sheer brutalism," says Remnick-describes well the whole technocratic movement that seeks, for example, to replace elected mayors with appointed "city managers." Another Wolin term that may catch on is Superpower without the Cold War article the or a. "Superpower" puts a new anthropomorphized twist on a familiar concept, and the capital $S$ links in with the longtime French custom of referring to an anthropomorphized governmental/administrative apparatus as the State. In place of "fugitive democracy," Wolin's "discordant democracy" might be more successful; in place of "inverted totalitarianism" perhaps "the new totalitarianism" (TNT). I would avoid "soft totalitarianism" because TNT follows the policy of "speak softly but carry a big stick" and is hard when it needs or wants to be, such as in Guantanamo or Bagram. The long-term success or failure of these neologisms is unpredictable.

152. See William Deresiewicz, “The Disadvantages of an Elite Education," American Scholar (Summer 2008), referenced in Andrew Delbanco's op-ed, “A Smug Education?” New York Times, March 8, 2012. 
153. Cornel West's use of the word magisterial to characterize Manning Marable's biography Malcolm X: A Life of Reinvention (New York: Penguin, 2011) does not augur well for the sales of that book.

154. One need only think of the desired comic effect when the American tourist in Paris poses mockingly next to Rodin's famous sculpture depicting cerebral effort.

155. In meritocratic France, however, it is common for publishers to name on the back cover the university that the author graduated from as well as concours achievements and other honors and titles. See, for example, Yvan Elissalde, Du Silence: L'homme et ses prosopopées (Bordeaux: Presses Universitaires de Bordeaux, 1997) _ “Yvan Elissalde, né en 1965, ancien élève de l'École Normale Supérieure, Agrégé de philosophie, Docteur de l'Université ParisSorbonne, enseigne actuellement au Lycée de Blaye.”

156. Overall, Wolin is both a sympathetic and resistant reader of Tocqueville. He admires strengths, but does not hold his tongue about what he considers to be troubling moments in Tocqueville's writings and actions, notably his recommendation of "tough love" in the prison essay and his problematic resistance to socialism in the 1848 period. Wolin resists falling under Tocqueville's spell, while casting a few of his own, perhaps inadvertently.

157. Two other examples would be Wayne C. Booth (1921-2005), who published his breakthrough book The Rhetoric of Fiction (1961) when he was forty, and Angus Fletcher (1930-), who published Allegory: The Theory of a Symbolic Mode (1964) when he was thirty-four. Fletcher also published A New Theory for American Poetry: Democracy, The Environment, and the Future of the Imagination (2004) at age seventy-four.

158. In this respect Wolin's later rhetoric is not so unlike Rahe's, though they offer very different diagnoses of “democracy's drift.” This might be an example of what Cass R. Sunstein calls "group polarization." See his Going to Extremes: How Like Minds Unite and Divide (Oxford: Oxford University Press, 2009). This is a book-length expansion of an early Sunstein essay, “Deliberative Trouble? Why Groups Go to Extremes," Yale Law Journal 110:71 (2000): 71-119.

159. In the French university setting, a lecture course is called a "cours magistral."

160. It is worth recalling Tocqueville's challenging address to the reader in the rousing Introduction to DA I, 60, G6: "Where are we headed, then? No one can say, because we have no basis for comparison." And yet everyone has $a$ say, because in a democracy, meanings (sens) and directions (sens) are not determined vertically, from high to low, but horizontally by all stakeholders.

161. On the question "Who controls the Internet, and, thereby, its fate?" see Vinton Cerf, “Keep the Internet Open,” New York Times, May 24, 2012. See also Carl Bildt's celebration of a recent resolution endorsed by the United 
Nations Human Rights Council, “A Victory for the Internet,” New York Times, July 5, 2012.

162. On France's blindness to the Arab Spring, see, for example, Pierre Vermeren, "Printemps arabe: Pourquoi la France s'est aveuglée," Libération, February 17, 2011, 22: "Having built so many myths in partnership with authoritarian and corrupt Arab elites, the French ended up believing in them: Arabs, Berbers, Kurds, Persians can only be governed by force. Dictatorship is a necessary evil that alone will permit the transformation of these societies at some future time. For now, the irrationality, religiosity, and chronic violence of these peoples necessitates an authoritarian government!" (my translation).

163. Besides Tocqueville's observations on demoland envy in DA I, 2, 5, see the prizewinning study by Richard Hofstadter, Anti-Intellectualism in American Life (New York: Knopf, 1962).

164. This is an excerpt from Thomas Pavel's review in the Wall Street Journal quoted on Amazon.com's sales page for this book.

165. As far as that coherence extends. Wolin is not silent about the questionable coherence of Tocqueville's praise of the process of mastering and taming (dompter) prisoners, especially the use of solitary confinement, a form of lawful tyranny that needs to be compared with Tocqueville's account of the death-in-life solitude of the dissident writer who transgresses majority opinion in democratic societies (cited above, DA I, 2, 5, 294, and DA I, 2, 7, 354).

166. I am purposely echoing here the large questions Tocqueville addresses to his readers in the Introduction to DA I: "Where are we headed, then? No one can say, because we have no basis for comparison.... [G6] Where, then, do things stand?... [G13] Has every other century been like this one? Has man always confronted, as he does today, a world in which nothing makes sense? In which virtue is without genius and genius without honor? In which the love of order is indistinguishable from the lust of tyrants? In which the sacred cult of liberty is confounded with contempt for the law? In which conscience casts but an ambiguous light on the actions of men? In which nothing any longer seems forbidden or allowed, honest or shameful, true or false? [G13]”

167. In Democracy Incorporated (118) Wolin elaborates on this definition of the archaic and distinguishes it from the relic, which is dead. The archaic is living on, ghostlike, a "presence of the past" that is hard to master and therefore potentially subversive.

168. Wolin's chapter on the "Dynamics of Archaism" in Democracy Incorporated shows how the archaic can either resist the present, as one would intuitively expect, or oddly consent to the futurist, permanently revolutionary "new" program of Superpower. Wolin would be providing here a different, perhaps more compelling answer to Thomas Frank's question, What's the Matter 
with Kansas? (2004). An important moment in the chapter is Wolin's halt to ask a real question: "The Question: is the archaic ultimately antithetical to a power-and-profit regime and its technology of continuous innovation; or is the archaist's dedication to the timeless implicitly exploiting the intolerableness of existence under the reigning mania for the new; and is its political support for Superpower a tactic, a way of hurrying society toward the apocalypse?" (121-122). That, it seems to me, is a real question. The strategies of suppression and exclusion, which include the dismissive rhetorical question and ridicule as two tactics among others, are directed against the threat represented by the archaic. Other examples would include the need to turn Thoreau, a man who embraced the archaic against the onslaught of the market-, tech-, and transportation revolutions of his day, into an eccentric figure of fun or into the hero of a children's story that represents him as a bear, not a man (see D. B. Johnson, Henry Hikes to Fitchberg [New York: Houghton Mifflin, 2000]); or Robert Frost, whose embrace of the archaic during the time of the rise of the military-industrial complex is neutralized by turning him into a harmless, grandpa figure writing nature poems in a cozy place called Bread Loaf. Similar attempts at suppression of the archaic elements in Wordsworth, Emerson, Ruskin and Morris, and others uneasy about "keeping up with the times" (in French, "vivre avec son temps”- see Yasmina Reza’s play Art [1994]) could be recounted.

169. Jacques Derrida also had recourse to this metaphor for his title Spectres de Marx $(1993,2006)$. 

II

Democracy 

Chapter 3

\section{"Who controls the meanings of democracy and, thereby, its fate?"}

Not everyone who is interested in democracy (to build it or block it) is necessarily interested in what Tocqueville had to say on the subject. Millions of course have never even heard of him. Tocqueville enthusiasts may regret this, just as admirers of Freud or Saussure may regret the lack of attention accorded to those "founding fathers" by contemporary practitioners in the fields they pioneered. But that's the way it goes, especially in democratic times where memory is faulty, time is scarce, and history and the other humanities subjects struggle to remain in the lifeboat of the university.

Democracy, however, seems to be on everyone's mind lately, with or without Tocqueville's help. ${ }^{170}$ But appearances and perspectives can diverge. ${ }^{171}$ The NGO Freedom House divides the world's seven billion people into three groups according to whether they are living in countries that are "free" (43\%), "partly free" (22\%), or "not free" (35\%). In other words, $57 \%$ of the world's population do not live in an open society (it was 61\% in 1989) and therefore literally cannot know (in their bones) what's being talked about when democracy comes up for discussion. ${ }^{172}$ This was obvious in Tocqueville's day but is probably overlooked by some contemporary authors of books with democracy in the title who may too easily assume that their audience has at least a rough idea of the subject. My point is the foreignness of democracy should not be underestimated, and even those who believe they are living in a fairly open society may never have really thought about what democracy means, let alone what its history or future might possibly be. ${ }^{173}$ 
Of those who think, write, or speak about democracy today we can identify four main groups. First, those who primarily do statistic gathering and analysis such as Freedom House, Democratic Audit, openDemocracy, Equality Now, and similar policy studies organizations dedicated to compiling and disseminating information about democracy and its core values (free and fair elections; an open and accountable government; civil and political rights; a curious, productive, public-spirited civil society). Second, authors of recent studies of democracy, which in English would include the work of Stephen G. Breyer, Bernard R. Crick, Robert A. Dahl, Larry Diamond, John Dunn, David Held, John Keane, Richard A. Posner, Robert Putnam, and Charles Tilly. ${ }^{174}$ In French, besides Emmanuel Todd, there are the books of Fabienne Brugère, Marcel Gauchet, Sandra Laugier, Jacques Rancière, and Pierre Rosanvallon, who also supervises an important political science website (La vie des idées) and a collaborative democracy-analysis project (La république des idées) with the publisher Seuil. ${ }^{175}$ Third, would be the authors of "big picture" books for whom democracy is usually an important piece in a larger puzzle. These authors are frequently named in lists of the world's top public intellectuals. They include Jacques Attali, Thomas Friedman, Jürgen Habermas, Paul Krugman, Kishore Mahbubani, Parag Khanna, and Amartya Sen, for example. Their books are easily recognizable with bold titles such as How to Run the World or Tomorrow Who Will Govern the World? or Can Asians Think? and they regularly turn up at "grand strategy" forums and summits around the world-Davos, WTO, G-20, etc. ${ }^{176}$ The fourth group are the rest of us: ordinary people who have never been called "whiz kid" or "genius" and who may or may not read, vote, belong to a political party or other interest group, sign petitions, write letters to leaders or newspapers, demonstrate, or talk about politics at the dinner table-and who may or may not even be allowed to do one or more of those things under local law and mores. Each of these groups has a different amount of power-imprecisely measurable and ever changing in the Internet age-when it comes to controlling the meanings of democracy and, thereby, its fate.

This last group is in theory the most powerful in a democracy, since when it comes to selecting leaders, numbers are supposed to trump other criteria (such as family ties, intelligence, wealth, physical strength, or 
beauty). But in practice we know it does not always work out that way. Ordinary people have long been the main concern of the first group of fact gatherers, but before the Internet age the information they gathered was not readily available and what was collected was exploited mostly by elites in government, business, and academia since the information was typically stored in large libraries to which only they and a few others had access. The main concern of academic elites, whether democracy authors or big picture book authors, is more complicated. Whether they care more about ordinary people and are writing to them and for them, or instead for other elites like themselves, is a real question. Obviously the audience one chooses to write for conditions both what one says and how. A strong suspicion of a conflict of interest or loyalty disconnect between academic elites (who can use the Internet to further amplify their talking points) and ordinary people (whose chance to be heard is more hit or miss) is probably behind derogatory names for the former, including "the chattering classes," "pointy heads," or "pundits." And today "blogosphere" competes with "ivory tower" to describe where elites congregate, while "academic" is still shorthand for "beside the point, irrelevant."

And yet in the Internet age the humble fact gatherer and organizer has the potential to become much more powerful as the information can be relayed more, and in more ways, than when those roles for shaping and transmitting were solely in the hands of professors, university presses, and librarians. Formerly only eyewitness accounts, whether elite or popular, could be relied on as a source of information about facts on the ground. Therefore diaries, memoirs, and the narratives of professional or amateur historians, as well as literature (poems, plays, narrative fiction) and other arts (music, painting, sculpture, photography, cinema), were valuable sources to get an idea about what was really going on inside a particular regime whether "free," "partly free," or "unfree." But those personal accounts, whether fiction or nonfiction, Proust or Pepys, still represented the reality of only a small selection of the overall population even if some of them emanated from nonelite sources and news outlets. Today that is changing as social networks, e-mail, and other forms of communication make "broadcasting yourself" easier and more affordable.

The information gathered and organized at the websites of Freedom House, Democratic Audit, and Transparency International, to name just 
three, is as available to ordinary people with basic computer knowledge as it is to elite brainworkers such as Robert Putnam or Pierre Rosanvallon. At least in theory. One needs to keep in mind that the two billion richest people in the world count six times as many Internet users as the other five billion and possess ten times more personal computers. ${ }^{177}$ The gap in cell phones, however, is only three to one, which suggests the upcoming potential for larger shifts in power as knowledge becomes more widely shareable. This will of course also depend on whether information on the Internet remains widely accessible, in other words whether the Web becomes more or less democratic, accessible, and "crowdsourced" in the years ahead.

The example of Democratic Audit is instructive. This website based at the University of Liverpool is a valuable source of information about how various countries around the world measure up when it comes to democracy. The nonprofit organization that runs the website was started in the years directly following the end of the Cold War when it was clear that British democracy was underperforming. Three key founders of the organization, David Beetham, Kevin Boyle, and Stuart Weir, developed the idea of conducting an "audit" of democracy in the United Kingdom in the early 1990s in response to a massive social and political problem, and an embarrassing one for a country that, along with the United States and other so-called Western democracies was supposed to be feeling upbeat after the collapse of the Soviet Union and the fall of the Berlin Wall. The reality, they say, was quite otherwise.

Our starting point has been the widespread sense of unease among both the public and political elites about the quality of government and public life in the UK and the deteriorating relationship between the people and their government. This unease is long-standing and cumulative. The public now tend to believe that their country is becoming less democratic; they want more power than they now have between elections; and they have lost confidence and trust in elected politicians. There has been a broad gap in the 1990s between people's satisfaction with their own lives and with public life, politics, and democracy in Britain. 
That assessment from the opening page of the first audit, Political Power and Democratic Control in Britain: The Democratic Audit of the United Kingdom, dates from 1997, the first year of Tony Blair's decade as Labor Party prime minister when hopes were high that "a new relationship between government and the people, based on trust, freedom, choice, and responsibility," was about to start. ${ }^{178}$ Since then three more audits of democracy in the United Kingdom have been completed (1999, 2002, 2009), and the practice has been imitated by many other countries around the world, but not necessarily by the ones you would expect or hope would lead the way. Neither France nor the United States, for example, is listed among the countries that have conducted an audit to assess people's power and political equality in those lands. In fact only nine of the G-20 countries have done so. ${ }^{179}$

The democratic audit of the UK in 2009 provides valuable and easily accessible information for anyone wishing to better understand, for example, the 2011 summer riots in London and other English cities. It is worth knowing, for example, that voter participation has declined significantly in the UK over the past twenty years (dropping from turnouts averaging roughly $75 \%$ from 1945 to 1990 , to roughly $65 \%$ today) and that the four lowest postwar turnouts have all occurred since 1997. ${ }^{180}$ More troubling are the statistics about who is not voting. The voter turnout gap between lower income versus higher income British citizens (55\% vs. $75 \%)$ signals a sharper disaffection for democratic practices in the United Kingdom among the part of the population that in theory has the most to gain from democracy, such as by voting in favor of progressive taxation and the redistribution of private wealth in the form of government-subsidized and government-supervised public services (notably schools and hospitals) that benefit everyone. Also noteworthy is the fact that membership in political parties has fallen from roughly three million to less than half a million over the past fifty years. However, other forms of political participation-signing a petition, discussing views with an elected representative, attending political meetings - while low, have remained fairly steady over the past ten years; and membership in more special-interest organizations such as nature conservation groups has significantly increased. Overall, on the matter of popular participation, the 2009 UK democratic audit shows (1) a shift away from the more 
traditional political processes within a representative democracy toward more direct democratic involvement and (2) a growing class divide when it comes to levels of political involvement.

Unless reversed, the second fact will likely confirm one of the basic observations of Tocqueville's "audit" of American democracy in 1835 and 1840, namely that extreme inequality renders democracy nearly impossible since radically unequal citizens do not have the same interests and therefore will see no reason to cooperate freely and fairly in developing and carrying out projects together ("traiter en commun les affaires communes"). It's worth remembering that democracy in America was only possible because of that "new thing" that so struck Tocqueville during his nine-month stay: "equality of conditions." How is it possible to make democracy work in an era of expanding inequality of social conditions? That is the question facing Britain's current prime minister, David Cameron, and others who have been looking recently to Tocqueville for inspiration to construct a new "Big Society" in the UK with a rejuvenated local community spirit. ${ }^{181}$ In a context of extreme social inequality, however, one of the necessary conditions for a renewal of democracy and peaceful, productive civil society is missing, and it is not surprising in such a situation that people are not just indifferent to "politics as usual" but revolt against the entire "system" that they no longer believe is working for them, but on the contrary rigged against them. ${ }^{182}$

The tools developed by Democratic Audit allow anyone to better understand how that rigging - in both the nautical and negative senses of the term-works. A list of eighty-five criteria grouped into six key areas-(1) free and fair elections, (2) universal suffrage, (3) election of key officeholders, (4) popular control of the political agenda, (5) access to alternative sources of information, (6) freedoms of association and expression-allow anyone to become an auditor to assess whether democracy, i.e., popular control with political equality, really exists and to what degree. These questions can be asked on the level of a particular territory (city, county, region, nation) or about a social structure within a territory such as a school, a company, or another social entity where collective decision making takes place (the United Nations, say, or NGOs such as Democratic Audit itself). These criteria allow the auditor to ask about how well democracy's "mediating values" are being upheld. How 
well does a particular government, school system, or health care network measure up when it comes to the values of authorization (granting power), accountability, ${ }^{183}$ participation, representation, responsiveness, solidarity, and transparency? How well does a particular government (1) respect the rule of law, (2) combat corruption, (3) protect civil, political, economic, and human rights, (4) encourage freedom of the press and free association and discourage media monopolies and overly powerful special-interest groups, (5) keep the military and police under civilian control, and (6) mediate a peaceful coexistence between itself and more local as well as more international levels of democratic practice? The number and variety of questions can seem daunting (the first democratic audit of the UK is over five hundred pages), but asking them and working to get answers is essential to those who believe, like the Americans who drafted the U.S. Constitution, that establishing "good government from reflection and choice" is preferable to yielding to "accident and force" (Federalist \#1, first paragraph).

Introducing Democracy: 80 Questions and Answers by David Beetham and Kevin Boyle (1995) is a more manageable primer for anyone in Cairo or Chicago who may have downloaded Gene Sharp's how-to book, From Dictatorship to Democracy: A Conceptual Framework for Liberation, and is now looking for more guidance about how to make democracy work once the possibility for its genuine existence has been established. ${ }^{184}$ Former Soviet bloc countries such as Hungary and Russia provide clear evidence of how ephemeral liberation can be if democracy's ground rules are poorly understood or only understood on paper without the deep learning that comes over time from the lived experience of democracy. Countries that succeed at the first steps of transitioning from dictatorship to democracy need more help when it comes to implementing and sustaining democratic practices, such as public debate and accountability, and seeing why they matter. They need to not only be persuaded rationally but experience daily what Tocqueville called "the real advantages" of democracy: i.e., (1) that it feels good to live free of arbitrary domination, (2) that democracy is more effective than other systems at protecting rights and the rule of law, (3) that democracy advances the wellbeing of the greatest number and results in better economic performance because it encourages confident entrepreneurship and productivity, and 
(4) that democracy makes for more pacific national and international relations because rational patriotism encourages one to be public-spirited, which eventually means accepting not only that my interests and the country's interests overlap, but that what's good for the "habitat for humanity" (clean air and water, arable soil, stable ecosystems, as well as literacy, transparency, individual rights, etc.) is also good for me.

These and other truths about democracy were not at all self-evident to many of the peoples suddenly left to their own devices at the end of the Cold War. Many witnessed instead a new power grab and the persistence of authoritarian habits, including arbitrary, behind the scenes decision making with no public accountability; the protection of hierarchical privilege; encroachment on other branches of government; widespread corruption and secrecy; and violations of civil, economic, and human rights. ${ }^{185}$ Even today, twenty years later, many of these countries are having a hard time believing in and caring about making democracy work. Some even express nostalgia for their former unfree condition. ${ }^{186}$

Nevertheless, it is in everyone's interest-even that of hardened oligarchs, one could argue - to facilitate a more successful and sustainable set of transitions from dictatorship to democracy in the Middle East and to help countries around the world whose transitions have stalled to find solutions to get back on track instead of turning into mafia-like oligarchies or slacking off and accepting regression into hopeless servitude.

And then there is the troubling case of the so-called Western democracies. which, instead of leading by example since the end of the Cold War, are each guilty of serious infractions of the basic ground rules of democratic government. ${ }^{187}$ Studies documenting extreme inequality, election fraud and other forms of corruption, political gridlock, collusion with private corporate interests that disregard wider public interests, violations of individual rights, and low accountability have become the daily "news" in Western Europe and North America, supposedly democracy's stronghold.

For all three of these groups-(1) the recent and less recent transitioning countries, (2) backsliders like the UK, the United States, Italy, and France, as well as (3) ordinary citizens in countries still vaguely dreaming about the possibility of democracy such as Iran or China-reading Introducing Democracy is a quick way to get one's bearings. This thorough 
and accessible synthesis of all of democracy's essentials, accompanied by attention focusing cartoons by Plantu, "was commissioned by UNESCO as part of its programme of education in democracy and human rights" and was published "simultaneously in many languages" in the 1990s. I have been unable to track down a list of those languages, but I imagine many former Soviet bloc Eastern European languages were included. One hopes that the volume will appear in Arabic, Farsi, and Chinese if it hasn't already and be more widely read in its original English version, because it is arguably the best introduction to democracy available.

There is no need to summarize this already short text (135 pages), but it is worth praising some of its decisions and positions. Organizing itself as eighty questions was an excellent choice. It engages ordinary readers, especially those unfamiliar with democracy either as an idea or an experience who really want answers to questions such as \#13, "Can any country attain democratic government?" or \#9, "Is a free-market economy necessary to democracy?" and of course \#2, "Why should we value democracy?" The eighty questions are divided into five sections that treat (1) "Basic Concepts and Principles" (\#1-15); (2) "Free and Fair Elections" (\#16-35); (3) "Open and Accountable Government" (\#36-50); (4) "Individual Rights and Their Defense" (\#51-63); and (5) "Democratic or Civil Society" (\#64-80). Parts Three, Four, and Five comprise the "chief components of democracy" that make up what the authors call "the democratic pyramid" (see the figure on page 31 ).

The succinct, forthright answers to all eighty questions cannot be listed here, but a few extracts are worth including as an incitement to further reading. In their concluding statement to the opening section, the authors note that democratic government is on weak soil if civil society's associations are not themselves organized and operated democratically.

If people are conditioned to authoritarianism in the family, the school and the church, and if they have no experience of self-organization or co-determination in the workplace, the neighborhood and voluntary associations, they are unlikely to be active citizens or feel any responsibility for the condition of their society at large. (33) 
The view, first put forward by Tocqueville, that democracy must be more than a form of government but a way of life that operates to various degrees in all contexts of collective decision making is repeated several times, notably in question \#73, "What role can schools play in education for democracy?"

A democratic education involves not only the acquisition of knowledge [of the rights and duties of citizenship, for example], however, it is also fostered through the experience of debate on issues of current importance, of presenting arguments and listening to the views of others, and of sharing in collective decisions on matters affecting the life of the school and its community, for example through classroom assemblies, elected school councils, and so on. (119-120)

In answer to question \#23, "Should voting be compulsory?" the authors answer diplomatically that "there's something contradictory about making a 'free election' compulsory, or requiring more people to exercise their 'rights"' (41), and yet they do see an advantage to making registering to vote compulsory since this would allow election organizers to "legitimate electoral purposes, such as equalizing the number of voters in constituencies, which require a full and accurate return to be made" (43). In other words it would help fight gerrymandering, ballot stuffing, and other fraudulent schemes.

The authors also make tactful observations about the plurality system of voting (also known as "first-past-the-post" or "winner-takes-all”). Although having the merit of simplicity, this system ends up exaggerating the impression of support for the largest party and is undemocratic since some votes are in effect "wasted," a fact that undermines the basic democratic principle of political equality. (See \#28, "What are the differences between electoral systems?" and \#29, "What are the advantages and disadvantages of these systems?” pp. 50-55.)

What comes back over and over in this introduction to democracy is that (1) people need to be able to practice democracy (and not just be told about it) in order to care about fostering it and "deepening" it (a metaphor used several times); and (2) gross inequality of opportunity kills democracy. 
We can conclude this evocation of the pedagogical efforts of Beetham and Boyle with their answer to question \#58, "How do social and economic rights relate to democracy?"

In the democratic pyramid (see question 15), the fundamental rights which secure employment, housing, food, an adequate living standard, education and other needs are treated as constituting the essential foundation of civil society. A society where there is widespread hunger can only achieve democratic politics very imperfectly. The satisfaction of the basic human need to survive is a necessary platform if democracy is to function. Democratic principles require that each elector or citizen should have an equal voice. To the extent that there is gross inequality in life chances, in access to education for example, the democratic potential of a society is severely limited. At the same time democracy as a collective process is a means whereby such inequalities can be identified and alleviated. (100)

The authors' insistence on democracy as a "collective process" and a "means" is worth pausing over because it demonstrates the hopeful note that runs through this book. This hope is founded on the belief that while some misfortune may be the result of bad luck and accidents, much is the result of bad policy, and that bad policies can be identified and replaced by better policies. There is the further belief that democratic institutions are the best "aggregation mechanism" (Surowiecki) for collective decision making by a variety of ordinary, differently talented people because they get the best results over the long term. This ties into what Tocqueville was getting at when he said democratic peoples had the advantage of making "repairable mistakes" because, unlike oligarchy or monarchy or any other closed, vertical, conflict-intolerant system of government by the Few over the Many, democracy is not opposed to learning from its own mistakes, to feedback loops, "error reports," and whistle-blowers. ${ }^{188}$ In fact, such continuous, collective, self-examination and cross-examination about what the public good is and the best means for attaining it is at the heart of democratic practice, even if it is often resisted and hard to do. 
This may all sound obvious, and in a sense it is to anyone who has given it some thought or had the good fortune of living and working in a democratically run town, country, school, or company. But often these best practices are neglected or ignored and in many cases have not even crossed the minds of those who have never known anything but paternalistic, authoritarian rule. The former may possess the theory but lack practice; the latter lack both-all they've ever heard is "My way or the highway," and therefore they have no idea how democracy (public debate, listening, testing, compromise, accountability, etc.) works. Introducing Democracy and The Democratic Audit of the UK are useful Tocquevillebrand tools for implementing a new democracy or repairing an old one, and both can contribute to sustaining a democracy that works better over the long haul, with regular "checkups" and "patches," than any other operating system.

\section{$\phi$}

According to the Democratic Audit website, only about thirty or so countries have followed the UK example and conducted a systematic "audit" of democratic practices within their territory. It is disappointing but not surprising that France and the United States are not among them. Disappointing because they are two countries that have also frequently expressed universalist pretensions, claiming to set an example for others to imitate; and not surprising since both countries have a history of pride and occasional smugness that can blind them to some of their own failings and leave them touchy about the ones they half recognize. For both, acknowledging a possible weakness and following a good idea that comes from longtime rival England is not easy to do. ${ }^{189}$ See Tocqueville on the effects of envy and resentment (e.g., DA I, 2, 5) —an important subtext in all of his major writings.

The U.S. and France happen to be the two countries I know best, or am least ignorant about-having now spent almost equal parts of my life in each. When asked how they compare, my reply for the past twenty years has been that each is the bad conscience of the other, and I think that still holds true today. Americans' "rugged individualism" (whether "manly" self-reliance à la Steve Jobs or stubborn anti-intellectualism à la George W. Bush) would seem to prevent them from coming together and 
agreeing on a set of democratic audit criteria, whether those of Beetham, Boyle, and Weir or someone else's set of indicators. Hence we get the Joshua Mitchell audit, the Paul A. Rahe audit, the Sheldon S. Wolin audit, the Stephen Breyer audit, and a hundred others all diagnosing "drift" or "fragility" or "gridlock" or some other "democracy deficit" for which the auditor is often light on workable solutions. These may be well-meaning studies motivated by a genuine desire to see the situation improve; but they are generally uncoordinated and therefore rather isolated and weak and can end up mutually drowning each other out even as they compete for attention-a typical scenario in democratic times as noted in DA. Moreover, their presentation styles suggest they are not addressing those who would derive the most benefits from more democracy, namely ordinary unemployed, underemployed, or overemployed people with kids and aging parents to care for; and these first two features (going it alone and talking over the heads of ordinary busy people) turn off readers who come to doubt an author's motives (How interested in democracy is he really?) and methods (Whatever happened to "treating common things in common"?)

The French resistance to a democratic audit is a bit different, since it is still far from certain whether a majority of French people really want to live democratically in the first place. A paternalistic "guardian" republic such as Plato described is good enough for many of them, especially it would seem for most elected officials in Paris and the provinces, who are mostly all older, white, male career politicians. For centuries France has been a country that believes in one-person-one-social-status (in French statut social; e.g., peasant, merchant, industrialist, student, soldier, politician, etc.), and this monolithic essentialism about one's identity ("Je suis dentiste," for example) runs counter to democracy's requirement that nonspecialist voices not only be tolerated but actively encouraged to contribute to collective decision making. ${ }^{190}$ Not to mention democracy's approving acknowledgment of the amateur, the semiprofessional, the multitalented, multitasking jack-of-all-trades, and his or her openness to changing jobs, cities, spouses, etc. ${ }^{191}$ Except in special circumstances, amateurism has negative connotations in France and is rejected as unserious, "pas sérieux." Therefore, conducting a democratic audit-a general, continuous self-examination that itself comes dangerously close to the 
idea of self-governance - would be conceding too much ground of legitimacy and desirability to democracy, and France's power elite has resisted letting that cat out of the bag for over two hundred years.

Hence the rather marginal impact of the numerous pro-democracy publishing achievements of Pierre Rosanvallon-in his own name and on behalf of collaborators. ${ }^{192}$ Another symptom is the derision poured on the high-ranking Socialist and presidential hopeful Ségolene Royal, who had the audacity to call for "participatory democracy" during her losing effort against then candidate Nicolas Sarkozy in 2007. ${ }^{193}$ The expression amounted to an admission that France's brand of democracy is "an empty shell, a form without any substance" to borrow Beetham and Boyle's characterization of a state where ordinary people come to see no point in democracy, "because it seems to have no relevance to their everyday lives and the situations in which they live them" (132). Yet the expression also contained within it the affirmation that the French were not fated to live in a fake democracy but could, if they cared to, live in a real democracy.

A third symptom of French ambivalence toward democracy is the regular appearance of publications by individual auditors of the American kind-Emmanuel Todd of course, but also Jacques Attali, Nicolas Bavarez, and Hervé Kempf, for example-whose books lamenting the sad state of governance in France may be found on sale in train stations and other popular book outlets for a few months before disappearing in the news cycle amid endless political and social scandals, stock market news, and talk about sports, vacations, one's employability ("insertion professionnelle"), or retirement ("retraite"), and the weather. ${ }^{194}$ The granddaddy of all such singular auditors was Tocqueville himself, but as I've already said his comeback or "rediscovery" in France is uncertain at best.

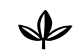

For the record, as our own synoptic audit, it may be worth recalling some of the highlights in the history of democracy in America since Tocqueville's day. Major influences (negative and positive) on democratic practices include the following:

Mass immigration in the $1820 \mathrm{~s}$, ' 30 s and '40s puts into question the social homogeneity that was instrumental in getting democracy off to a good start in America. Also, millions of new white males crowd in and 
push down the socioeconomic aspirations of women, blacks, and Indians by blocking or delaying their access to jobs and the public sphere.

The Civil War further puts into question the unity of the country and the idea of a "general interest" that applies over the whole territory. ${ }^{195}$ However the North's victory does prove that "the bullet would not replace the ballot" when a minority is unsatisfied with the outcome of an election. It teaches the minority a lesson about the necessity of being a "good loser" under a democratic regime and accepting the role of "loyal opposition." It also reveals that while the "omnipotence of the majority" is a real danger, so is the powerlessness of a majority when it faces a divisive and well-organized minority faction capable of disrupting national unity and throwing into doubt and disarray the coherent, widely shared beliefs and collective aspirations of the Many. ${ }^{196}$

The rise of large corporations challenges the democratic state because in general they are run autocratically and not democratically, and therefore the "work world" increasingly becomes a glaring antidemocratic contradiction within American civil society. ${ }^{197}$ U.S. factory life and the time and efficiency management studies known as Taylorism establish a despotic state within the state - a situation that resembles the society described at the end of DA II, 2, where Tocqueville imagines the lean and mean "aristocratic" disposition that the division of labor and scientific management techniques could bring about.

The slow but steady push back by labor unions tries to establish more freedom, equality, and "horizontal," democratic self-governance in opposition to the vertical corporate hierarchy. Labor unions oppose the corporate model but could sometimes fall into some of the same bureaucratic abuses_-rigid hierarchies, lack of transparency, exclusivity — and thereby undermine their oppositional legitimacy. ${ }^{198}$

There is the steady rise in literacy, the increasing number of high school graduates, and the rise of American universities and colleges thanks to the land-grant funding system and donations from some corporation presidents who respond to Andrew Carnegie's "Gospel of Wealth" exhortation. ${ }^{199}$ Quality schools, colleges, and universities become-like the legal community Tocqueville admired-a counterforce that relies on literacy and memory and as such is able to moderate the tyranny of the majority in the United States, as well as democracy's penchant for the 
immediate and the approximate "good enough" solution, by creating a mostly benign guild aristocracy that prizes history, planning, precise and loving craftsmanship, beauty, and truth and defends academic freedom and self-governance through the institutions of teacher unions, tenure, peer review, and faculty senates and student councils. ${ }^{200}$

These conflicting pressures on democracy (to strengthen or to weaken it) are followed in the twentieth century by several governmental paradigm shifts that all move in the direction of greater equality of social condition.

They include the following: FDR's New Deal (America's first experiment with European-style "social democracy") and his defense of the Four Freedoms: "Freedom of Speech, Freedom of Worship, Freedom from Want, Freedom from Fear."

The continued increases in literacy and the number of high school educated people, and the mass expansion of college educated people (which accelerated after 1945 with the G.I. Bill).

Nonviolent resistance movements that result in greater inclusiveness, social solidarity, and civil, social, and economic rights victories:

1. For African Americans in the 1960s (Montgomery, Birmingham, Selma [AL], Albany [GA], St. Augustine [FL]) thanks to Martin Luther King, Jr.'s example and President Johnson's “Great Society” leadership (Civil Rights Act, 1964; Voting Rights Act, 1965).

2. For women in the 1970s and 1980s (despite lingering wage inequality, discrimination, sexism, and the still unratified Equal Rights Amendment).

3. For homosexuals in the 1990s and 2000s (despite lingering discrimination and the as yet unattained national acceptance of "gay marriage" or "marriage equality").

On the other hand, there are many negative trends that have weakened democracy in America (especially since the 1960s) in the following areas:

Elections: the exaggerated importance of money and paid political consultants in election campaigns; ${ }^{201}$ unlimited donations by corporations and unions; ${ }^{202}$ negative campaigning; style over substance; 
personality and celebrity positioning over policy and program politics; gerrymandering; irregular and sometimes illegal electoral procedures; disparate, unwieldy, and inconvenient voting procedures such as continuing to hold elections on a workday. ${ }^{203}$

Education: federal, state, and local cuts in public education budgets for $\mathrm{K}-12$, colleges, and research universities; skyrocketing education costs and student debt; widespread attempts to redefine education as a private good (to be paid for by the "customer") instead of a public good to be financed to a significant extent collectively through taxes and government spending and supervision.

The press: media monopolies; extremes of overly quiescent or hyperaggressive behavior in the media; generalized venality that places private profits over public interest; the financial crisis of print media without a workable business model in the Internet age; underfunding of investigative journalism and the homogenizing effect of overreliance for content on wire services, press releases, and partisan think tanks and lobbies such as the American Legislative Exchange Council (ALEC).

The state: expanded numbers and powers of nonelected officials in career civil service administrations, quasi-nongovernmental organizations, and subcontractors; multiculturalism's perpetuation of "separate but [not] equal"; the legislative and judicial rollback of "affirmative action" for women and disadvantaged minorities and the resistance to class-based affirmative action; ${ }^{204}$ categorical, divisive antigovernment rhetoric and behavior since Goldwater and Reagan; tax revolts; low voter turnout for general elections and a proliferation of single-issue referenda that undercut trust and pride in representative democracy; decline of rational patriotism, resurgence of jingoistic patriotism; the abuse of the filibuster and other congressional rules (arcani imperi) that cause "gridlock"; an unrepresentative, obstructionist Senate; no term limits on members of Congress, many state governors, and most judges; ${ }^{205}$ elective judgeships and campaign finance abuses by judges.

The economy: lack of supervision of corporate America and Wall Street; deregulation; weakening of labor laws and denigration of unions; low accountability to customers and clients; the stagnation of incomes of the American middle class since the 1970s; sharp declines in U.S. family assets since $2007 ;^{206}$ the spread of "unpaid internship" scams; mostly 
silent acceptance of "corporate welfare" through tax subsidies, credits, reimbursements, and exemptions, and of "affirmative action for the rich" through legacy set-asides in higher education and "entitled mediocrity" (the gentleman's A-); retreat from a progressive tax code (lowering of the highest tax bracket, and favorable tax rates on capital gains and carried interest); abandonment of "the war on poverty" and the proliferation of "blame the victim" counteroffensives - calling the poor "lazy," "undeserving," "takers," "cheaters," lacking in "character"; the accentuation of "a culture of extreme inequality."207

Religion and social mores: increased public space and airtime accorded to self-righteous religious organizations that divide Americans into saved and damned; the abuse of "identity politics" and the return of a winnertake-all "spoils system."

Another category of double-edged, positive and negative influences on democracy in America, from 1945 to the present, would include the following:

The Cold War: a spur to introspection and progress, "win hearts and minds," the Apollo space program; MLK and Malcolm X use the "Freedom" ideology of U.S. foreign policy as a lever to advance domestic social changes versus a spur to wall off and refuse change; an alibi for selfrighteousness: McCarthyism, "better dead than red," "my country love it or leave it," and the banalization of "the paranoid style in American politics" (Hofstadter).

The War on Terror: reaffirmation of basic rights versus fearful, docile yielding of rights (see "Patriot Act"); foreign wars of choice (Korea, Vietnam, Iraq, Afghanistan); neighborly U.N. "nation-building” efforts in former Yugoslavia territories and elsewhere versus arrogance of outside meddling experts.

Mass immigration: new ideas and energies versus exploitation, social wedge, xenophobia, and homesickness.

The Internet: greater access versus less guidance; more freedom, less accountability; blogging brings more, alternative reporting and also more "preaching to the converted," "group polarization," profiling, and secret surveillance; potential for "cyber-democracy" versus potential for "the revival of the propaganda state" 208 and cyber-bullying. 
E-mail and social media: a chance for better communication, dialogue, and understanding versus a risk of less and worse communication with filtering, unchecked incivility, deception, and incitements to attacks (both cyber- and real).

The major challenges that American democracy faces todayextreme inequality, low social solidarity, a wavering commitment to public service, and an ill-defined general interest—all make it difficult for the president and Congress to unite the nation around necessary reforms in the areas of health care, education, and energy policy, for example. That the country has major long-standing problems in these and other areas (law enforcement, decent jobs, housing, environmental protection, etc.) is not disputed, but how to describe, rank, and solve them is the source of major disagreements that impede effective action such that many have begun to doubt Tocqueville's claim about the "real advantage" of democracy's high productivity. ${ }^{209}$

As any reader of Barack Obama's Dreams from My Father (1995) knows, the difficulties of "community organizing" in a culture of extreme inequality have existed in the U.S. for forty or fifty years at least. They were summed up thirty years earlier in the nervous title of a book by Martin Luther King, Jr., Where Do We Go From Here: Chaos or Community? (1967). King, Lyndon Johnson, and Franklin Roosevelt may have done more than anyone else to make democracy in America something more than a dream, myth, decoy, or distant legend recounted by an idealistic, freedom-loving French aristocrat, but sustaining their achievements has become very difficult to say the least. Tocqueville may have wanted to believe that expanding equality of social conditions was "providential"; but his own historical account of the material changes that gradually brought about greater equality over the preceding seven centuries implies that man's will, not God's, could change and swing things back toward greater inequality. As President Obama discovered (and the South Chicago community organizer before him), it takes not just $a$ village, but millions of local initiatives to nurture community spirit and sustain democratic habits and institutions, in America or anywhere else, because democracy is not the work of one or several heroic individuals, nor is it a static guaranteed inheritance. ${ }^{210}$ It is instead a living credo that people can govern themselves translated into a way of life that daily bears 
out a faith in mankind's intelligence, imagination, passion, and compassion and welcomes the organizational skills and wisdom of individuals of differing talents, predispositions, and interests. ${ }^{211}$

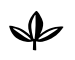

If democracy in France today has not been exhaustively evaluated by any national or international group such as Democratic Audit, it's safe to say that its strengths and weaknesses are somewhat different from those in the United States. ${ }^{212}$ They can be fairly easily summarized as follows. Perhaps the leading strength is that, for now, with the exception of some fringe groups on the Left and Right, France is not divided into "different moral visions," 213 nor is any major political party behaving irrationally or having irrationality become its default mode or new normal. For example, no member of any major French political party is running for governmental office on the slogan "government is the problem," nor is anyone proposing balancing budgets while simultaneously cutting taxes (especially the taxes of the richest). In other words, for two generations France has benefited from a fairly strong centrist consensus about desirable social ends (e.g., clean air and water, affordable health care and housing, quality public schools, secure decent jobs, livable wages, access to arts and parks, etc.) and, for the most part, about the ways to attain those goals.

The biggest problem (because it risks disrupting that consensus about social ends and means) is that, like in the United States, income inequality, or a division into "two Frances," has grown significantly in recent years, and this division is putting added strain on the already delicate but nevertheless still fairly stable postwar welfare state (état providence) of France's Fifth Republic. ${ }^{214}$ Political, economic, and social equality for women and minorities living in France did not fully come about when times were good (roughly 1945-1975), though the lot of French women did improve somewhat comparatively speaking (right to vote 1955, birth control pill 1967, decriminalization of abortion 1975). The progress for minorities (especially the children and grandchildren of North African immigrants) - always difficult to measure in France due to laws restricting ethnic identification in census data-appears to have stalled in the last thirty years, ${ }^{215}$ during which France's economy has cycled through 
so-so years and bad years. But France's comfortable white male elites ${ }^{216}$ have managed to cushion political inequality and soften socioeconomic inequality during the leveling off of the country's overall prosperity thanks to deficit spending that has maintained fairly egalitarian systems of health care, housing, and education that remain broadly accessible and of relatively high quality. Compared to conditions in the countries of origin of most French immigrants (Eastern Europe, North Africa, Southeast Asia), these basic life-support systems still function pretty well and therefore add to the country's attractiveness alongside its long-standing reputation as a popular tourist destination. However, strains on the social fabric and periodic attention-getting crises are increasingly visible. ${ }^{217}$

If France has remained fairly "democratic," in the above-named sense of affordable and accessible, when compared to the United States, it remains to be seen how and for how long those favorable conditions will be sustained. And as affordability and accessibility become more difficult to sustain (amid rising housing prices, increasing health care costs, and inequality between schools), levels of anger are likely to increase over the lack of decision-making power accorded to ordinary citizens. ${ }^{218}$ In other words, so long as times were fairly good, one kind of democracy (access to goods and services-what the French usually mean when they talk about démocratisation) could make up for the lack of the other kind of democracy (i.e., political power). But as the good times become a distant memory for all but a few, and the majority of French youth face not just the prospect but the present reality of living less well than their parents and grandparents, they may demand that the French Republic grant more political equality and accept living with more democratically run institutions. $^{219}$

The law about legislative parity between male and female legislators is one symptom of a certain impatience with the state of democracy in France. ${ }^{220}$ Other features of the French Fifth Republic that are likely to become the focus of more vocal protest in the years ahead include the following:

Cumul des mandats, i.e., the possibility for an elected official to hold more than one elective office simultaneously, such as mayor and National Assembly deputy. Currently 80\% of France's deputies hold another elective office. This practice limits political participation (which 
is exactly the intention of those who favor it) and necessarily aggravates problems of absenteeism (since a deputy-mayor cannot be in his town and the National Assembly in Paris at the same time) while increasing elected officials' reliance on aides, "briefings," and other secondhand information.

The Sénat, whose members are elected indirectly by local elected officials (in a way similar to the U.S. Senate prior to the Seventeenth Amendment of 1913). France's Senate is designed to be that temperate body of more dispassionate, wise legislators that the Federalist and Tocqueville both praise as a useful counterweight to the possible tyranny and impulsive unreason of minority or majority "faction." However, there is a danger that its members can be disinterested to the point of becoming disconnected, in effect an "old boys' club" out of touch with the realities of ordinary French people. Others who are more at ease with paternalistic politics - either because they are one of the fatherly "old boys" or have been one of the winners within that system-find the Sénat venerable and not venal, not senile but sensible.

Term limits. With his election in 2007 and defeat in 2012, Nicolas Sarkozy became the second French president to serve the reduced term of five years. (In 2008 France changed from unlimited seven-year terms to a maximum of two five-year terms.) The previous two presidents, François Mitterrand and Jacques Chirac, had served fourteen $(2 \times 7)$ and twelve years $(7+5)$, respectively. There are no term limits, however, for other elected officials in France, and French mayors are noted for being on average among the oldest in Europe (57) and retaining political power for decades.

The Question of the independence of the judicial branch in France and its accountability. This is a vast complex subject about which ordinary French citizens know very little, one reason being that there are no juries or jury duty in France and therefore the experiential education in how the judicial system works in France from the inside is missing. Most people have little knowledge of the judicial system unless they happen to be directly implicated in it either as a criminal or victim of crime. Crime and court scandals are a part of every news cycle of course, and occasionally there are massive consciousness-raising affairs, such as the Affaire Dreyfus (1895-1906) or more recently the Affaire d'Outreau (2004-2005), 
which exposed contemporary weaknesses in the French justice system, notably concerning the powers of the juge d'instruction. But for the most part, crime and justice are treated superficially and emotionally in the major media with little effort at educating the public or including them in this area of collective decision making. The French like to repeat that "No one is supposed to be ignorant of the law"; and yet law and the legal world in France is generally considered the arcane domain of experts and remains shrouded in mystery, while the ordinary citizen is often left feeling passive and powerless ... which suits those in control just fine.

Education. France's National Education system is the country's biggest employer, and its critics compare it to a wooly mammoth (big and prehistoric) and to the Soviet Union (rigid, bureaucratic, unfree, hypocritical). Nowhere perhaps are the strengths and weaknesses of France's paternalistic preferences more in evidence than in its schools. The principal strength comes in the area of socialization and the transmission of basic knowledge, which is why France continues to do a credible job when it comes to preschool, primary, and secondary education. Socialization (i.e., learning to work together in a group and toe the line) is well carried out by the clarity, order, and rules that are the hallmarks of French "classical" education. But France gets lower marks when it comes to the equally necessary "romantic" sides of the educational development of older teenagers and young adults, namely individualization, self-reliance, experimenting, debating and sifting, problem solving, and innovation. ${ }^{221}$ France can be praised for not going the way of the United States and Great Britain, where it has increasingly been decided that education is a private good to be paid for by the "customer." In France, nursery school through doctoral studies, ages three to thirty roughly, remain essentially tuition-free on the theory that educating each generation of young people is a collective responsibility and in everyone's interest since the workforce of tomorrow will be the country's economic engine and, crucially, will finance the retirement of the workforce of today. However, merciless tracking and teaching to the test begins very early (around age eleven), and students have access to very different amounts of financial and emotional support over the following ten to fifteen school years, often depending on how savvy, wealthy, and well-connected their parents are. State spending on students in France's university system is notoriously 
low compared to per-student spending on primary and secondary education-not to mention the lavish public spending on classes préparatoires that groom France's talented tenth for entry into its selective and wellfunded Grandes Écoles, an array of private and public schools that are the gateways to power, prestige, and wealth in France. ${ }^{222}$ There is also the problem of France's long-standing bias in favor of the cerebral (especially mathematics) and contempt for the manual despite massive lip service to the contrary (Concours Lépine, Prix des meilleurs ouvriers de France, etc.) - an obvious stumbling block when it comes to competing internationally with industrial powerhouses such as China and Germany, or even with Denmark and Finland. It is no accident that the leader of the pigs, i.e., the "brainworkers," in Orwell's Animal Farm (1945) is named Napoleon (changed to César in early French translations of that ageless "fairy story"). For centuries in France, from royalists to republicans, oligarchy did not pose a problem, and top-down, centralized Napoleonic methods in all areas from agriculture to telecommunications to education have been the accepted norm.

So long as France's elites had only to convince themselves of their own superiority and believe in the "meritocracy" that had formed them and that they had inherited and would in turn administrate to form the next generation-essentially a form of national cloning through cooptation and "sending down the elevator" (renvoi d'ascenseur) — there were no serious challenges to the status quo. The disruption of "mai ' 68 " is ritually exaggerated in France and resulted in no paradigm shift within l'Education Nationale. It's during the Internet age-after the collapse of the Soviet Union and Communism (which many French educators sympathized with all along), and especially since the European Union's Masstricht Treaty (1993) the Shanghai international rankings of colleges and universities (2003-), and the global impact of Google and Facebook-that France has felt the heat of the international spotlight directed at its educational mores and top-down methods generally. ${ }^{223}$ Since 1989, in a world that is increasingly "hot, flat, and crowded," France's national education system has found itself having to compete like never before both to place its graduates and to convince international students to do their studies in France and adopt the "Made in France" label. And at the same time it must convince its own best people not to flee the country. ${ }^{24}$ Pockets of 
complacency and sheltered privilege are quickly drying up ${ }^{225}$ as France's education system struggles to embrace ideas like "self-reliance," "innovation," and "imagination" that its strict, military heritage going back to Napoleonic and pre-Revolutionary Catholic teaching methods had prohibited. ${ }^{226}$ It remains to be seen whether France innovates in a direction that simply becomes leaner and meaner than it already was toward the $80 \%$ of the population whose hearts and minds were never really the primary concern of France's teacher-gatekeepers; or whether the country's schools can recast their harsh meritocratic model and embark on a new less complacent direction that would nurture the thoughts and feelings of each child and essentially educate for citizenship within a democracy instead of merely training a workforce for obedient fulfillment of necessary tasks within a tightly regulated republic. ${ }^{227}$

Europe. European and transcontinental pressures (in the form of treaties and other international agreements and initiatives that regulate the circulation or blockage of goods, services, and people) have caused changes within France's National Education system, but this is true in every other sector of French society as well-agriculture, industry, trade, tourism, hospitals, prisons, and energy and environmental policies. This "global" impact of the international on the national raises the question of national boundaries and national identity that France has also been struggling with for the very good reason that there can be no republicdemocratic or paternalistic - without a clearly defined public, i.e., rules that decide who is in and who is out, who gets to vote, work, pay taxes, receive government money directly or indirectly... and who doesn't. When Tocqueville traveled to America in 1831 it still took over a month to cross the Atlantic in a sailing ship, and even in 1931 or 1981 there did not exist today's super rapid movement of people, goods, and services that has caused the very notions of nationhood and national sovereignty to become wobbly.

One solution to the problem is to give up on the idea of a bounded "public sphere" based on territorial birth and a chosen set of naturalization laws, for example. Those willing to give up on this traditional idea of a public are often also giving up on the idea of the political and hence of government. They seem to be in favor of simply allowing individualsliving persons defined by the life and death of their physical bodies-to 
enter into agreements with other individuals or other private entities (businesses for example) to buy and sell goods and services as their interests dictate. It's the idea of "Doctors without Borders" generalized to all trades and professions-defense contractors without borders, call centers without borders, credit default swaps without borders, etc. ${ }^{228}$

A second solution, which had many sympathizers after the international disorder brought on by the two World Wars of the twentieth century, goes in precisely the opposite direction: instead of giving up on the idea of a public, it makes it the cornerstone of a unitary conception of human belonging within which particular publics or republics (nations if one wants to still use that term from the preglobalized era) are allowed at least nominal existence. The United Nations and other international organizations were founded to coordinate and harmonize what were still called out of habit countries into one supranational republic, organized as much as possible along democratic lines with shared values and aspirations embodied in the Universal Declaration of Human Rights and other such documents.

A third solution would be a situation where a traditional public continues to be bounded in its identity with certain material and symbolic documents such as passports and anthems, and by concrete measures such as elections and paying taxes into this national treasury as opposed to that one; but most large decisions would be made not by elected individuals but by nonelected world commissions of energy experts, education experts, production experts in the areas of agricultural and construction, water management, and so forth. People would not be a public in the traditional sense but closer to what Tocqueville called "les administrés" (DA I, 131)_administrated units supervised and regulated by a worldwide system of controllers to use Huxley's term or cadres (literally "frames") as the French say.

A fourth solution looks at the upcoming shortages in fossil fuels ("peak oil") and the limited ability (at present at least) to bring other energy sources on line quickly enough and sees an inevitable scaling down of globalization and a return of localism and small-scale operations, protectionism, and tribalism. This has been the fertile ground for muscly extremist parties and paranoid vigilantism in "rude nations" throughout history. 
Perhaps at no time since the 1920s and 1930s-once known as "the long weekend"-have there been so many conflicting views about whether human societies could or should move in the direction of greater universalism and internationalism, protectionist clannish isolationism (brothers and others), or regionally defined alliances with one's closest neighbors no matter who they are (hang together or hang separately).

After the "revolutions" of Tocqueville's day, and the second series of rapid and extensive changes that started about a century later with the banalization of cars, electricity, indoor plumbing, and centralized heating and cooling, then air travel, then high speed rail, container ships, and computers, there is now a third emergent "revolution" in transportation, communication, energy, education, and health care captured by the name "the Internet Age" that, coupled with the lingering negative effects of the economic downturn that began in 2008, has led many to draw comparisons between our contemporary opportunities and crises and those of the 1930s. ${ }^{229}$ After arguing at length in favor of the contemporary usefulness of a certain French witness of the 1830s, I would like to now consider the guidance offered by three British witnesses from the 1930s, George Orwell, Aldous Huxley, and E. M. Forster, as well as the thoughts and feelings of two internationalists of English origin, Charles Spencer Chaplin, Jr., and the late Tony Judt. ${ }^{230}$

\section{Notes}

170. And some vociferously reject his help. See, for example, Daniel Choi, "Unprophetic Tocqueville: How Democracy in America Got the Modern World Completely Wrong," Independent Review (Fall 2007): 165-178.

171. For Amartya Sen, the ascension of democracy is the most distinctive characteristic of the twentieth century. See his La Démocratie des autres, trans. Monique Bégot (Paris: Rivages, 2006 [1999, 2003]). And yet in a recent op-ed piece, "The Crisis of European Democracy," New York Times, May 22, 2012, Sen has expressed his alarm about democracy's recent setbacks in Europe.

172. Besides this lack of experiential knowledge, there are linguistic barriers. The French language, for example, has no word for shallow water-it has to say, "eau peu profonde." But that is less troubling than not having easy equivalents for the words accountability, accountable, or responsive government, for 
example. In other words, crucial vocabulary for introducing the notion of democracy and explaining what it consists of does not readily exist in French. One can imagine this is also true for many other languages spoken in places where democracy has either never existed or, as with France, been disparaged through most of its history.

173. Americans who grew up reciting "The Pledge of Allegiance" and take democracy for granted are generally unaware how much criticism and how little enthusiasm there have been for the democratic form of government in most places throughout human history-including France, which has for over two centuries preferred meritocracy as a "halfway house" (Elster) between aristocracy and democracy.

174. See the bibliography for the titles of books by the authors named in this paragraph.

175. La vie des idées: <http://www.laviedesidees.fr>. La république des idées: $<$ http://www.repid.com>.

176. Parag Khanna, How to Run the World: Charting a Course to the Next Renaissance (New York: Random House, 2011); Jacques Attali, Demain, qui gouvernera le monde? (Paris: Fayard, 2011); Kishore Mahbubani, Can Asians Think? Understanding the Divide between East and West (Singapore: Times Books International, 1998). For a profile of Davos, see Nick Paumgarten, "Magic Mountain: What Happens at Davos?” New Yorker, March 5, 2012, 44-53.

177. See the poster supplement " 7 Milliards de visages" in the French edition of National Geographic magazine, March 2011, as well as the January 2011 English-language issue cover story "Population 7 Billion." See also the Wikipedia entry "Global Internet Usage." For a profile of telecommunications entrepreneur Mo Ibrahim's efforts to combat dictatorships in Africa, see Ken Auletta, “The Dictator Index,” New Yorker, March 7, 2011, 44-55.

178. The idea of a "new relationship" comes from Tony Blair's New Britain-My Vision of a Young Country (1996). Blair's sentence appears as an epigraph along with a key passage from James Madison's Federalist \#51 (1788) about the necessity of "auxiliary precautions" that will help the people to oblige governors to behave responsibly. Not surprisingly, the unease about the quality of government and public life in the UK in the 1990s coincided with the lived experience of widening income inequality. By the 1990s Britain had become more unequal than at any time since the 1940s. See John Hills, Income and Wealth: The Latest Evidence (York: Joseph Rowntree Foundation, 1998), and John Hills, ed., New Inequalities: The Changing Distribution of Income and Wealth in the United Kingdom (Cambridge: Cambridge University Press, 1996).

179. The G-20 countries in italics have conducted a democracy audit according to the Democratic Audit website, formerly http://www.democraticaudit.com/ 
audits-worldwide: Argentina, Australia, Brazil, Canada, China, European Union, France, Germany, India, Indonesia, Italy, Japan, Mexico, Russia, Saudi Arabia, South Africa, South Korea, Turkey, United Kingdom, United States.

180. This information is viewable at the website <formerly http://www. democraticaudit.com/key-indicators-of-uk-democracy $>$. For comparison, it is worth noting that voter turnout in French legislative elections in June 2012 was the lowest in the history of the Fifth Republic, with almost $45 \%$ abstaining. The abstention rate in the second round of the 2012 presidential election was $20 \%$. See a complete review of the 2012 presidential and legislative election results (and comparisons with the 2007 results) at the website of Le Monde: <http://www.lemonde.fr/resultats-electionpresidentielle/> and <http://www.lemonde.fr/resultats-electionslegislatives/>, accessed June 20, 2012.

181. For a summary of the Big Society project and its problems, see Lauren Collins, “All Together Now: What's David Cameron's Big Society About?" New Yorker, October 25, 2010, 38-48. For a longer account, see Jesse Norman, The Big Society: The Anatomy of the New Politics (Buckingham: University of Buckingham Press, 2010). See also, Matthew Hilton and James McKay, The Ages of Volunteerism: How We Got to the Big Society (Oxford: Oxford University Press, 2011).

182. It's understandable that critics of the Big Society see it as a cynical "bait and switch" ploy to shift responsibility to the private individual and force acceptance of government's abandonment of its longtime role as the public's steward and defender. See also the testimonies about lives mangled in the Big Capitalism societies of France and the U.S. as told by the journalists Florence Aubenas (Les Quais de Ouistreham, 2010) and Barbara Ehrenreich (Nickel and Dimed, 2001). For an even darker testimony, see Roberto Saviano's Gomorrah: Italy's Other Mafia (2007, [2006]) and the film adaptation by Matteo Garrone (2008).

183. Accountability could be defined as getting leaders to be answerable to their constituents when they take on responsibility for specific missions, to submit to periodic "audits," and when appropriate to accept punishment for mishaps that occur "on their watch"; i.e., to be answerable for mistakes and misbehavior. Many books in English contain the word accountable or accountability in the title. See, for example, Roger Connors and Tom Smith, Change the Culture, Change the Game: The Breakthrough Strategy for Energizing Your Organization and Creating Accountability for Results (2011). Connors and Smith are the authors of two previous studies on the same topic: The Oz Principle: Getting Results through Individual and Organizational Accountability (with Craig Hickman, 2004) and How Did That Happen? Holding People Accountable for Results the Positive Principled Way (2009). See also "Accountability" in Wikipedia. 
184. David Beetham and Kevin Boyle, Introducing Democracy: 80 Questions and Answers (Cambridge, UK: Polity/UNESCO, 1995).

185. Besides the efforts of the well-established NGO Human Rights Watch (http://www.hrw.org), see the experiment to expose and reduce corruption in India at the website http://www.ipaidabribe.com/.

186. See Seth Mydans, “20 Years after Soviet Fall, Some Look Back Longingly,” New York Times, August 18, 2011.

187. Wolin goes even further and sees Superpower as the mostly intended consequence of a big merger between eviscerated democracies and overly powerful corporations. This is his main claim in Democracy Incorporated (2008). For another indictment of violations by the United States of the Universal Declaration of Human Rights, see the op-ed piece by former president Jimmy Carter, “A Cruel and Unusual Record,” New York Times, June 24, 2012.

188. At least in theory. In practice, it takes courageous (or desperate) individuals to keep the omnipotent majority from totally shutting out "inconvenient truths," "unpopular essays," and all disobedience and insubordination in opposition to the practices of the dominant culture. Witness the "noisy exit" of Greg Smith in his open letter of resignation from Goldman Sachs published on the op-ed pages of the New York Times, "Why I Am Leaving Goldman Sachs," March 14, 2012. Such public declarations are frequently met with damage control maneuvers that often include condemnation of the whistle-blower. Witness the difficulty police officers have reporting corruption within their ranks: Joseph Goldstein, “Officers, Exhorted to Report Corruption, Still Fear Retaliation,” New York Times, June 24, 2012. Or Witness the backlash against Andrew Lohse, a recent denouncer of Dartmouth College's dehumanizing fraternity culture as reported by Janet Reitman, "Confessions of an Ivy League Frat Boy: Inside Dartmouth's Hazing Abuses,” Rolling Stone, April 12, 2012. Lohse's editorial, “Lohse: Telling the Truth," appeared in the campus newspaper the Dartmouth on January 25, 2012. And then there is Roberto Saviano, who is living the Salman Rushdie life under police protection outside Italy after receiving death threats in retaliation for his whistle-blowing investigative journalism in Gomorrah: Italy's Other Mafia. On the Bradley Manning / WikiLeaks case, and the threat to democracy of an uninformed citizenry, see Floyd Abrams and Yochai Benkler, "Death to Whistle-Blowers?” New York Times, March 13, 2013. The authors cite the statement by U.S. Supreme Court justice Hugo L. Black in the famous Pentagon Papers case from 1971: "The guarding of military and diplomatic secrets at the expense of informed representative government provides no real security for our Republic." On Edward Snowden, the N.S.A., and investigative reporting by The Guardian, see Ken Auletta, "Freedom of Information,” New Yorker, October 7, 2013, 46-57. 
189. On the difficulty couples have giving and receiving criticism, see the cover story editorial in the Economist for March 31, 2012, "France's Future: A Country in Denial," and the article in the same issue, "The French Election: An Inconvenient Truth," 29-31. To which one reader of unspecified nationality responded in a comments thread, "The English accusing the French of denial is a classic case of the pot calling the kettle black."

190. France's essentialist thinking comes through in its obsession with everyone's distinct and singular état civil, statut social, and formation. For example, the French generally tend to avoid baking and prefer buying their pastry from a qualified pastry chef, who has received the proper training, diploma, and approval rating from his professional peers. An astonishing exception to this high respect for specific professional training and competency testing is the authorization that is granted to former deputies and ministers to practice law without passing any aptitude tests whatsoever. Understandably, this special arrangement that was updated in a April 3, 2012, government decree is unpleasing to many French lawyers and law professors. The French bar association, Le Conseil national des barreaux, sees the decree as irresponsible and a blatant invitation to lobbying abuses. The conseil hopes to see the decree overturned by the Conseil d'Etat, i.e., France's supreme court. See Nicolas Cori, "Le barreau parallèle des hommes politiques," Libération, April 6, 2012.

191. It is worth remembering that the French anthropologist Claude LéviStrauss famously associated the "bricoleur," the do-it-yourself tinkerer, with the uncivilized "savage mind" in La Pensée Sauvage (1962). On the enduring French aversion to bricolage, see Raffi Duymedjian, "La France snobe les vertus du bricolage," Le Monde, April 2, 2013, <http://www. lemonde.fr/economie/article/2013/04/02/la-france-snobe-les-vertus-dubricolage_3151937_3234.html >.

192. Rosanvallon's excellent La Société des égaux (Paris: Seuil, 2011) is unlikely to become a bestseller.

193. President Sarkozy's failure to get reelected in 2012 may have been partly due to possible democratic impurities in his $\mathrm{CV}$ as compared to the impeccable "guardian" credentials of François Hollande as a career politician. Royal's surprise defeat in the 2012 legislative elections may also have been further punishment for her spirited but losing efforts to expand beyond her own purist background and embrace "participatory democracy." See also the analysis of the 2012 presidential election by center-Right former minister Roselyne Bachelot in her book À Feu et à Sang (Paris: Flammarion, 2012) and also her own call for "participatory democracy" in an earlier study of the French mayor, Les Maires: Fête ou défaite? (Paris: Éditions Anne Carrière, 2001). For a profile of Sarkozy's predicament six months before the 2012 election, see Philip Gourevitch, "No Exit: Can Nicolas Sarkozy-and 
France-Survive the European Crisis?” New Yorker, December 12, 2011, 46-61.

194. See Nicolas Bavarez, La France qui tombe (2003), Aron: Penser la liberté penser la démocratie (2005); Hervé Kempf, Comment les riches détruisent la planète (2007), L'Oligarchie ça suffit, vive la démocratie (2011). On the difficulty of criticizing anything in America, including the weather, due to the people's "irritable patriotism," see DA I, 2, 6, 322, G271-272: “America is therefore a land of liberty where, in order not to offend anyone, a foreigner must not speak freely about individuals or the state, the people or the government, public or private enterprises, indeed about anything he finds there, except perhaps the climate and soil. In fact, one encounters Americans prepared to defend even the latter two things as though they had had a hand in making them." One wonders what Tocqueville would say about France's brand of irritable patriotism under the Fifth Republic.

195. Tocqueville had speculated about the country being torn apart by its own divergent interests when he witnessed the widening gap in the socioeconomic reality and mœurs of Kentucky, a slave state, and Ohio, a "free soil" state. See DA I, 2, 10, 459-463.

196. The reader of $D A$ must stay alert to these two opposite dangers-too much unity versus too little-because Tocqueville is less explicit than he could be about the necessity for majority rule to strike a balance so that it is strong enough to incite community spirit and rational patriotism, but not so strong that it chokes off dissenting voices, thereby provoking hurt feelings, anger, desires for secession or divorce, or even civil war. The Many must assert their prerogative as the majority but remain mindful of minority rights and the usefulness of a loyal opposition - a term coined by John Hobhouse in 1826 in the British Parliament according to the Wikipedia entry "Loyal Opposition."

197. See Alfred D. Chandler, Jr., The Visible Hand: The Managerial Revolution in American Business (Cambridge, MA: Harvard University Press / Belknap, 1993); and Alan Trachtenberg, The Incorporation of America: Culture and Society in the Gilded Age (New York: Hill and Wang, 2007). For an update on the problem, see Steve Coll, Private Empire: ExxonMobil and American Power (New York: Penguin, 2012).

198. See Melvyn Dubofsky and Foster Rhea Dulles, Labor in America: A History, 8th edition (New York: Wiley-Blackwell, 2010 [1975]).

199. See Christopher Newfield, Ivy and Industry: Business and the Making of the American University, 1880-1980 (Durham: Duke University Press, 2003).

200. See William Glasser, The Quality School: Managing Students without Coercion (New York: HarperCollins, 1998 [1990]). For two recent defenses of American higher education's social aspirations, see Geoffrey Galt Harpham, The Humanities and the Dream of America (Chicago: University of Chicago 
Press, 2011); and Andrew Delbanco, College: What It Was, Is, and Should Be (Princeton: Princeton University Press, 2012). On intellectual freedom and creativity in American universities, see Richard P. Feynman, Ralph Leighton, Edward Hutchings, and Albert R. Hibbs, Surely You're Joking, Mr. Feynman! Adventures of a Curious Character (New York: Norton, 1997 [1985]). For a succinct diagnosis of the decline of the humanities and a spirited call for their rejuvenation-complete with nod to Tocqueville-see Lindsay Waters, Enemies of Promise: Publishing, Perishing, and the Eclipse of Scholarship (Chicago: University of Chicago Press / Prickly Paradigm, 2004), 57.

201. For a brief history of political consulting, see Jill Lepore, "The Lie Factory: How Politics Became a Business,” New Yorker, September 24, 2012, 50-59.

202. See the Wikipedia entry Citizens United vs. Federal Election Commission, a Supreme Court decision dating from January 21, 2010. For a retelling of how the Citizens United decision happened, see Jeffrey Toobin, “Money Unlimited: How Chief Justice Roberts orchestrated the Citizens United Decision,” New Yorker, May 21, 2012, 36-47. See also Joe Nocera's editorial about the harm to democracy caused by unlimited campaign donations, "Buying the Election?" New York Times, October 8, 2012.

203. Overcoming the inconvenience of Tuesday voting with easy "early voting" procedures in almost all of the fifty states is a recent improvement in America's electoral system. For an overview, see the website of the National Conference of State Legislatures: <http://www.ncsl.org/ legislatures-elections/elections/absentee-and-early-voting.asp $x>$, accessed October 21, 2012.

204. See David Leonhardt, "Rethinking Affirmative Action,” New York Times, October 13, 2012.

205. Only fifteen states have term limits on state legislators. A chart with details about the conditions in each is available from the National Conference of State Legislatures: <http://www.ncsl.org/legislatures-elections/legisdata/ chart-of-term-limits-states.aspx $>$, accessed September 4, 2012. See also the Wikipedia entry “Term Limits in the United States.”

206. See the Federal Reserve's 2012 Survey of Consumer Finances (SCF) in Federal Reserve Bulletin 98:2 (June 2012). The report shows that American families' median net worth fell from $\$ 126,400$ in 2007 to $\$ 77,300$ in 2010, representing a 40\% drop. Median family income has declined for over a decade.

207. This is Barbara Ehrenreich's reverse-Tocquevillian observation at the end of her twelve-month journey through the world of low-wage workers in America, where she did stints as a waitress, maid, and chain-store clerk. See her exposé Nickel and Dimed (New York: Henry Holt, 2008 [2001]), 212: "There seems to be a vicious cycle at work here, making ours not just 
an economy but a culture of extreme inequality." Ten years later, after the crash of 2008, the Arab Spring, and the "Occupy Wall Street" movement, this message may be beginning to get through. Or not. For opposing views, see Steven Rattner, “The Rich Get Even Richer," New York Times, March 25, 2012; and Adam Davidson, "The Purpose of Spectacular Wealth according to a Spectacularly Wealthy Guy,” New York Times, May 1, 2012.

208. See Nancy Snow and Philip M. Taylor, "The Revival of the Propaganda State: US Propaganda at Home and Abroad since 9/11," International Communication Gazette 68 (2006): 389, <formerly http://gaz.sagepub.com/ content/68/5-6/389>.

209. It is not easy to determine whether the problem is democracy as such or democracy as constituted in America. On the latter possibility, see Adam Liptak, "Sidebar: 'We the people' Loses Appeal with People around the World,” New York Times, February 7, 2012; and Sanford Levinson, "Campaign Stops: Our Imbecilic Constitution,” New York Times, May 28, 2012.

210. In 1996, First Lady Hillary Rodham Clinton published It Takes a Village: And Other Lessons Children Teach Us (1996). The book drew fire from many conservatives, and former U.S. senator Rick Santorum published a rebuke in 2005 entitled It Takes a Family: Conservatism and the Common Good.

211. For an example of that credo in action, see the free print and online local newspaper the Forecaster serving towns in southern and midcoast Maine (USA), <http://www.theforecaster.net/>.

212. The closest thing to such an audit has been carried out over many years by Pierre Rosanvallon. However, an "equality audit" of the United States and France has been carried out in recent years by the economists Thomas Piketty and Emmanuel Saez (see Part Three, Chapter Two).

213. See Paul Krugman's stark outline of those two opposed visions in his column "Free to Die,” New York Times, September 15, 2011: “... American politics is fundamentally about different moral visions."

214. France's current constitutional government, known as the Fifth Republic, began in 1958 - thirteen years after the end of World War II and four years before Algerian independence in 1962. On the birth of the modern French nation following the German occupation and postcolonial turmoil on three continents, see Todd Shephard, The Invention of Decolonization: The Algerian War and the Remaking of France (Ithaca: Cornell University Press, 2008); and two classic studies: Alistair Horne, A Savage War of Peace: Algeria 1954-1962 (New York: New York Review of Books Classics, 2006 [1977]); and Robert O. Paxton, Vichy France: Old Guard and New Order, 1940-1944 (New York: Columbia University Press, revised edition 2001 [1972]). See also the widely respected studies by Benjamin Stora, for example, Algeria, 1830-2000: A Short History, trans. Jane Marie Todd (Ithaca: Cornell University Press, 
2001). For an overview of the political history of the Fifth Republic, see Arnaud Teyssier, Histoire politique de la Ve république, 1958-2011 (Paris: Perrin, 2011).

215. See the recent audits published by the French Middle East specialist Gilles Kepel, Banlieue de la République: Société, politique et religion à Clichy-sousBois et Montfermeil (Paris: Gallimard, 2012), and Quatre-vingt-treize (Paris: Gallimard, 2012).

216. In 2008, in the two chambers of France's legislative branch, women accounted for $22 \%$ of French senators and $19 \%$ of the "deputies" in the National Assembly (the French equivalent of the U.S. House of Representatives). In 2008, 14\% of France's 36,683 mayors were women.

217. In the eyes of many (not necessarily all racists or xenophobes), France's immigration and integration problems, for example, could be characterized as a case of "build it, and too many come." Few recognize immigrants as a powerful entrepreneurial engine, though it's been clearly demonstrated in the American case. Instead, who is entitled to what and on what conditions is at the center of a large problem of not just French but European Union sovereignty and social organization today. In France and elsewhere it is not always easy to differentiate between isolated incidents and general trends when it comes to problems of housing, health care, education, and the economy. For one attempt, see the cover story in the magazine Le Point for April 12, 2012, "Notre rapport sur l'état de la France-Les chiffres qui accablent, Les raisons d'espérer.”

218. Since 2007 and the presidential campaign of Ségolène Royal, there has been a steady (but still minority) demand for "participatory democracy," "real democracy," and "real socialism" - recently incarnated by the presidential candidacy of Jean-Luc Mélenchon. For a snarky summary of Mélenchon's recent national prominence, see Alain Duhamel, "Jean-Luc Mélenchon, notre grand poète national," Libération, March 29, 2012, 21.

219. France's lesser known "culture of extreme inequality" was highlighted in a Barbara Ehrenreich-like copycat experiment about "La France d'en bas" by the French reporter Florence Aubenas. See her best-selling account of life as a maid in Caen, Le Quai de Ouistreham (Paris: Éditions de l'Olivier, 2010). For a study of France's physically and mentally disabled, known as "les personnes en situation de handicap," see Yves Boutroue, En bas de la France d'en bas (Paris: L'Harmattan, 2005).

220. For an overview of the "parity" debate in France, see Gérard Pavy, La Parité: Enjeux et pièges, La dynamique des sexes au travail (Paris: L'Harmattan, 2010).

221. See Richard Rorty, "Education as Socialization and Individualization," in Philosophy and Social Hope (London: Penguin, 1999), 114-126. 
222. The details of these spending gaps, like the perks allocated to "special regime" subgroups within France's workforce, are mostly kept out of the newspapers. For an overview, see the work of French sociologist François Dubet, Les places et les chances (Paris: Seuil, 2010); and Dubet's admonitory op-ed piece from 2009, "Les pièges de l'égalité des chances" (The Traps of Equality of Opportunity), Le Monde, November 30, 2009. It is to be hoped that a French translation of Charles Murray's controversial Coming Apart (2012) will enter the public debate in France to add further arguments to supplement those of Dubet, and before him Pierre Bourdieu, about the social costs of meritocracy. An enterprising publisher might also consider translating into the French context Bill Bishop's The Big Sort (2008).

223. The spotlight is increasingly the cumulative effect of a "thousand points of light," now called "crowdsourcing," such as with this blogspot and the comments thread and links that it generates: <http://understandingsociety. blogspot.com/2013/03/decline-of-french-universities.html?utm source $=$ feedburner\&utm_medium $=$ feed\&utm_campaign $=$ Feed $\% 253 \mathrm{~A}$ +Understandingsociety+\%2528UnderstandingSociety\%2529>, accessed March 5, 2013.

224. In a recent survey of professor salaries (but not taking into account fringe benefits like health plans), France ranked 16th out of 28 countries, just behind Argentina and Malaysia and above Japan and Brazil. Canada was ranked first, the United States fifth. See D. D. Guttenplan, "How Much Is a Professor Worth?” New York Times, April 2, 2012. It is also worth noting that roughly 300,000 French citizens currently live and pay taxes in Great Britain, a third in London.

225. But not quickly enough for some. For now, posts in French public primary and secondary education are only open to citizens of European Union member countries through the concours recruitment process. This national and regional preference policy excludes Americans, Australians, and Canadians, for example, from becoming English teachers in France's public schools despite a glaring need for more and better teachers in this job sector.

226. The best-selling Walter Isaacson biography of Steve Jobs (Paris: JC Lattès, 2011) is perhaps even more of a sensation in France than in the U.S. since it is overturning four centuries of received ideas about science and the art of business from Colbert to Napoleon to Robert Schuman and the other French architects of the European Union. See also Malcolm Gladwell, “The Tweaker: The Real Genius of Steve Jobs,” New Yorker, November 14, 2011.

227. The caring, intelligent, usually male schoolteacher is a stock figure in a certain French cinema- “Au revoir les enfants" (1987), "Être et avoir” (2002), "Les Choristes" (2003) — but a more representative picture of France's schools, it could be argued, is a cross between toughness and absurdity, "The 400 Blows" (1959) and "L'Élève Ducobu” (2010). For a recent 
account by a disillusioned primary schoolteacher, see Kévin André, Les Désarrois d'un jeune instit (Paris: JC Lattès, 2006). The first chapter, "Voyage to the Heart of the Absurd," conveys the atmosphere of a system with multiple problems.

228. Interestingly, one of the founders of Médecins sans frontières, Bernard Kouchner, briefly served from 2007 to 2010 as Foreign Affairs Minister (Tocqueville's former post) in the center-right government of Nicolas Sarkozy, a decision that led to his expulsion from the Socialist Party. Since 2011, Kouchner has pursued his international bent as a consultant, with or without borders I do not know.

229. For a discussion of the three revolutions and where we might be heading now, see the widely discussed paper by economist Robert J. Gordon, "Is U.S. Economic Growth Over? Faltering Innovation Confronts the Six Headwinds," National Bureau of Economic Research, August 2012: <http:// faculty-web.at.northwestern.edu/economics/gordon/Is\%20US\%20 Economic\%20Growth\%20Over.pdf>, accessed October 30, 2012. For a summary, see Annie Lowrey, “A Dismal Outlook for Growth,” New York Times, August 28, 2012.

230. The list of witnesses could be extended to include Virginia Woolf and Christopher Hitchens, or Dorothy Day and Richard Wright, or many others in or outside the English-speaking world, but I shall stick to these five representatives. 


\section{Chapter 4}

\section{Restore Previous Session}

Call it, then, the state of exception: these years during which, in the name of security, some of our accustomed rights and freedoms are circumscribed or set aside, the years during which we live in a different time. This different time of ours has now extended ten years - the longest by far in American history — with little sense of an ending. Indeed, the very endlessness of this state of exception - a quality emphasized even as it was imposed - and the broad acceptance of that endlessness, the state of exception's increasing normalization, are among its distinguishing marks.

- Mark Danner, "After September 11: Our State of Exception" New York Review of Books, September 29, 2011

Even if a catastrophe can be avoided, one thing is certain: the pressure to reduce deficits will push the eurozone into prolonged recession. This will have incalculable political consequences. The euro crisis could endanger the political cohesion of the European Union. There is no escape from this gloomy scenario as long as the authorities persist in their current course. They could, however, change course. They could recognize that they have reached the end of the road and take a radically different approach. Instead of acquiescing in the absence of a solution and trying to buy time, they could look for a solution first and then find a path leading to it. The path that leads to a solution has to be found in Germany, which, as the EU's largest and highest-rated creditor country, has been thrust into the position of deciding the future of Europe.

- George Soros, "Does the Euro Have a Future?" New York Review of Books, September 29, 2011. 
"The primary will of the world is no longer about peace or freedom or even democracy; it is not about having a family, and it is neither about God nor about owning a home or land. The will of the world is first and foremost to have a good job. Everything else comes after that."

- Jim Clifton, The Coming Jobs War, quoted by Charles M. Blow, "For Jobs, It's War," New York Times, September 16, 2011.

One year before and after the over-hyped "Y2K" that was supposed to cause such big problems for us all via the difficulties that our computers more than ourselves would have crossing into the new millennium, i.e., in 1999 and 2001 to be precise, Europe and the United States entered into new eras that would fundamentally change the way the people in those territories would live. On January 1, 1999, the Euro was introduced as the single accounting currency of eleven countries of the European Union. ${ }^{231}$ On September 11, 2001 (four months after my daughter Rose was born) four passenger planes were hijacked for use in coordinated suicide attacks on New York and Washington, D.C. Nearly 3,000 people died. Those events in Europe and North America seemed at the time to be setting the two continents on very different paths, just as other events had done back in 1789. At that earlier time in the U.S., the revolutionary spirit of 1776 was being reined in somewhat as the country chose, narrowly, to ratify a new constitution and experiment with a federal government and its first president, George Washington (elected on February 4, 1789). With the storming of the Bastille on July 14, 1789, France, and with it Europe, embarked on the first wave of its Revolution that would inflame the continent, disrupt civil society, and provoke conflicts that would subside and reignite at irregular intervals for the next 150 years, swinging France and its neighbors between tyranny and license, to use Tocqueville's termstoo much government or too little - until the emergence of the European Economic Community (EEC) in 1957 and France's Fifth Republic in 1958 put things on a somewhat more even keel.

In the past dozen years, the roles seemed reversed, with Europe heading toward ever greater stability and cooperation between its member states, while the United States, which had been drifting recklessly for over 
a decade since the end of the Cold War, was, after "9/11," entering into a new period of panic-stricken crisis government characterized by an emergency mentality of permanent siege, permanent "revolution" and instability, rising inequality, and paralyzing disagreements between the two major political parties. While the U.S. was suddenly waking up to realities it had mostly ignored for fifty years, especially during its post-Cold War complacency ("Why do they hate us?" Is a democratic "free world" compatible with the rigors of modern capitalism? Should Christians be billionaires?), it's now widely felt that a European union was more a wish (of dogmatic dreamers in and outside government) than a fact, and that the European common currency was imposed without sufficient popular support, i.e., without taking the time to nurture a stable set of common mores or institutions, such as respect for the rule of law, to impose common tax and spending policies, or even to establish a common European treasury. In short, it was and still is a Europe without Europeans.

In 2008, the financial crisis caused the histories of Europe and the United States to converge and the illusions on both sides of the Atlantic to come into clearer focus. Parallels were drawn with the 1930s, another time when both Europe and America faced deep economic hardship, social instability, and class divisions. ${ }^{232}$ Those comparisons multiplied as the financial crisis became a full-fledged economic and political crisis on at least two continents with secondary effects that risk engulfing the rest of the world. Just as local conflicts morphed into "World War" on two occasions twenty years apart in the twentieth century, today many around the world are wondering what the local consequences will be of the acute Euro crisis and the steadily worsening crisis of America's ongoing "state of exception" that has crippled its democratic institutions, tarnished its moral standing in the world, and damaged its own faith in its usually positive, productive, can-do self. Have Europe and the United States simply gone too far this time and made mistakes that are unrepairable? Or can Europe and America follow the advice of George Soros excerpted in the epigraph above, namely "recognize that they have reached the end of the road and take a radically different approach"? "Instead of acquiescing in the absence of a solution and trying to buy time, they could look for a solution first and then find a path leading to it." But will they? And can they do this in a way that is democratic instead of employing the 
usual, and usually disastrous (for the 99\%), top-down, elites-know-best approach? We will soon find out since living in denial and on borrowed time (and money) appear increasingly unsustainable. ${ }^{233}$

One thing is certain: change will happen, and the way we live now will soon be different, either through deliberation and choice or accident and force. While thinking about upcoming changes, how they will feel, and what they will mean in the long run, it might be advisable to keep a cool head and recall, and perhaps learn from, another tense time that millions ultimately survived, though it's true millions did not, namely the 1930s. I find it particularly worthwhile to reconsider the testimony of three British witnesses: Orwell, Huxley, and Forster. Perhaps there is something special about being British that makes being a witness from that old country especially valuable. Could it be its geographic location between North America and Europe? Could it be its status as an island (I-land/eye-land) that endows its people with uncommonly acute powers as witnesses? Or is it just that Orwell, Huxley, and Forster were three exceptionally gifted and eloquent individuals? Perhaps there's no definitive answer, but I heartily recommend that citizens today who wonder "Where do we go from here, community or chaos?" take time out from their busy schedules and their focus on today's stock market news and unemployment figures to reread 1984, Brave New World, and Forster's essays (especially "What I Believe" from the collection Two Cheers for Democracy) and his narrative fiction (especially "The Machine Stops"). My purpose here is not to offer full readings of these works, but to draw attention to aspects of them that can broaden and deepen our understanding of Tocqueville, democracy, and the Internet age.

\section{Reading 1984 in the Internet Age}

Lately there have been many backward glances to the 1930s, especially to the causes and consequences of the Great Depression that famously began on October 29, 1929, and to the rise of National Socialism that reached a climax with Hitler's invasion of Poland on September 1, 1939, and England's declaration of war against Germany on September 3, 1939. The latter event was the focus of an acclaimed film, The King's Speech, released in 2010. One hopes this heightened attention to events that took 
place in the days of our grandparents and that bear certain resemblances to our own times (bank failures, massive unemployment, extremist politics) will yet allow us to avoid repeating the worst catastrophes of the decade that followed. With that goal in mind, it might be useful to unearth other documents, radio broadcasts, and films from that earlier era. I would recommend, for example, a remake of Charlie Chaplin's first talking film, The Great Dictator (1940), or at the very least an "HD" rerelease of the original. ${ }^{234}$ It might also be entertaining and instructive to do an Internet age remake of Orwell's 1984 since the original version, released in 1984 during the middle of the Reagan-Thatcher years, is marred by traditional totalitarian hyperbole and the ghosts of Wagner, Leni Reifenstahl, and Orson Welles. A new version, a job for Armando Ianucci, perhaps, or Matteo Garrone, could set the action closer to, say, 2004 or 2014, by which time Ingsoc and Newspeak would have advanced to a cooler, calmer efficiency appropriate to the Internet age of "cookies," drones, Google, and managed democracy's permanent "war on terror."

It's moving to watch The Great Dictator today, especially those memorable scenes of the coin in the pudding, the globe scene, and of course Charlie Chaplin's final impassioned speech, which he wrote himself in favor of democratic dignity and liberty. ${ }^{235}$ It's also instructive to recall the U.S. government's action in 1952 to keep Chaplin from reentering what had become his adopted country. Chaplin was a victim of McCarthyism, which, in a cruel irony, turned him into the homeless person he often portrayed in Depression-era films. Chaplin's humor might seem miles away from Orwell's gravitas, and yet his films and Orwell's writings are underlining a common vulnerable human condition with our upside potential for kindness and love, and our downside risk for violence, intolerance, manipulation, and being manipulated by others. They each knew what George Kennan was getting at when he said in a speech to the Naval War College in 1947-during the early, pre-McCarthy, Cold War time when Orwell was writing 1984 (it would be completed in 1948 and published in early 1949) — that "there is a little bit of the totalitarian buried somewhere, way down deep, in each and every one of us." Sheldon Wolin makes use of that claim as his epigraph to Chapter Two of Democracy Incorporated, entitled “Totalitarianism's Inversion: Beginnings of the Imaginary of a Permanent Global War." The full statement is this: 
The fact of the matter is that there is a little bit of the totalitarian buried somewhere, way down deep, in each and every one of us. It is only the cheerful light of confidence and security which keeps this evil genius down... If confidence and security were to disappear, don't think that he would not be waiting to take their place. (15)

Of course in 1947 it was impossible for Kennan to imagine the evil genius as also possibly a "she" resembling Margaret Thatcher, Condoleezza Rice, or Angela Merkel, for example, but nevertheless we get his point. Is it not the same point Charlie Chaplin is making when he decides to play two matching roles, the antihero barber-tramp and the Hitleresque dictator, Adenoid Hynkel? Is it not also why Chaplin injects the globe scene-a vivid representation of the dictator's total political control-with buffoonery (the humping fanny that sends the ball into the air) and ends it with a final pop, as well as the reason behind having the barber's final speech in favor of democratic socialism crescendo with a raised voice and mannerisms that recall certain enthusiastic speeches of the leader of National Socialism who is performing on stages across Germany at the very same time the movie is released in the United States?

"You must speak. -I can't. -You must, it's our only hope." This imperative to speak out and bear witness that immediately precedes the barber's improbable, surprising declaration would seem to have been a force behind the steady urgency of the writings of Orwell, Huxley, and Forster. ${ }^{236}$ Orwell's 1984 is written by a dying man (tuberculosis, like Tocqueville and Thoreau) who worries about the end of the world and does everything in his power-speaking, writing, leading by exampleto make it more likely that a decent world where people can work and play and love each other, and think and say what they want, and move about freely will survive. He puts everything he has and much of himself into what he must know will be his finale, a sort of valedictory address to the world. ${ }^{237}$

People who have read the book probably remember the rats and the torture in the grim third and final part. Those and other dark aspects of the novel are certainly what get played up in the 1984 movie version. Besides the sorrowing, however, there are many lighter moments of rejoicing and toiling (more or less happily). Winston Smith basically 
likes his job-rewriting history_and takes quiet pride in his language skills, both in English and Newspeak. He's glad to have fallen in love with Julia-standard middle-aged male gratification at winning the affections of a sweet young thing - and to have improvised a subversive love pact with her in defiance of the Party's interdiction of private lives and private thoughts and feelings.

Despite his brooding private side that makes him revolt against all pressures to conform (in conformity with the romantic social code of the artist-rebel), Winston likes people, likes striking up conversations, likes making connections. Thus he feels bad when his intellectual colleague Syme is "vanished"; when the avuncular shopkeeper Charrington who sold him the beautiful paperweight and rents him the upstairs "love shack" turns out to be a member of the Thought Police; or when the old man at the bar from whom he hopes to get a usable history about life before the revolution turns out to be a chatterbox of disjointed memories ("a rubbish-heap of details," 105); and of course when O'Brien, whom he thought was a freedom-loving member of the Brotherhood, and whom he looks up to somewhat like an older brother (there's even a phonetic resemblance, "O brother"), becomes his torturer-not Goldstein but lead, and misleading. But the fact that these relationships don't turn out well doesn't stop him from believing in people and the world, its objects and textures, until of course the final dehumanizing breakdown is complete. And even so, the novel's last verb is one of connection, "loved""He loved Big Brother."

It's worth noting, and I will return to it later, that this verb is in the past tense, just as it is worth noting the assortment of texts and variety of writing styles that Orwell packs into this book. Especially noticeable are the "Appendix" on "The Principles of Newspeak" and the interpolated book by Emmanuel Goldstein, The Theory and Practice of Oligarchical Collectivism, that Winston enjoys reading silently to himself and out loud to Julia (a clever means for reader sympathy-building). Other varieties of text include the Party slogans, "War is peace," "Freedom is slavery," "Ignorance is strength"; the scraps of English poetry (the "bells" rhymes); "prole” prose (e.g., "'E could'a drawed me off a pint"); prole song (e.g., "It was only an 'opeless fancy..."); Newspeak prose (e.g., "times 3.12.83 reporting bb dayorder doubleplusungood refs unpersons 
rewrite fullwise upsub antefiling"); and Ingsoc poetry-a rewriting of the American poet Henry Longfellow's sonorous ode to honest work and strength of character, "The Village Blacksmith," into a short, chiastic, punning ditty: "Under the spreading chestnut tree / I sold you and you sold me / There they lie, and here lie we / Under the spreading chestnut tree." In one of Orwell's many ironic winks, the pub where a range of living and dead souls while away their time, including Winston in the final chapter, is called the Chestnut Tree Café- "haunt of painters and musicians. There was no law, not even an unwritten law, against frequenting the Chestnut Tree Café, yet the place was somehow ill-omened" (64). It is the tragic antithesis of the Village Blacksmith's open air workplace, which is a sacred space where all the good, beautiful, and true lessons of life are learned.

Alongside the bowdlerized version of "The Village Blacksmith," Orwell allows himself some lyrical prose of his own that hearkens back to English romantic poetry of olden times. Here is the opening of Chapter Two in Part Two that will center around the impossible love of Winston and Julia (Orwell's wink at Shakespeare's star-crossed lovers Romeo and Juliet):

Winston picked his way up the lane through dappled light and shade, stepping out into pools of gold wherever the boughs parted. Under the trees to the left of him the ground was misty with bluebells. The air seemed to kiss one's skin. It was the second of May. From somewhere deeper in the heart of the wood came the droning of ring-doves. (135)

There can be no fall without first establishing the heights from which it will take place, no ugly hell without a beautiful heaven, no winter of discontent without first a midsummer night's dream. Orwell's tale hurtles toward its tragic conclusion with all the inevitability of Greek or Shakespearean tragedy. And that's the whole point. Orwell wants to pack the entire English language and the achievements of all of world literature, of all civilization practically, into this book. He wants it to be a readable omnibus of a book-his Ulysses (Joyce's had appeared in 1922). He clearly aspires to have it be a truly great book-one far surpassing Goldstein's political science master's thesis-a book containing 
thoughts and feelings, like seeds stored in air-tight jars, out of which human civilization could be rebuilt from the ruins of catastrophe. Orwell is sending a time capsule into the future, betting on what Tocqueville and Sheldon Wolin are also investing in, namely (1) the restorative power of the archaic (such as with the disinterested aristocratic treatise and the scholarly monograph) and (2) the subversive power (in a world where all must serve) of the gratuitous and useless (such as the glass paperweight with the coral inside: "It's a beautiful thing," 109). ${ }^{238}$

In 1948 Orwell, that is, Eric Blair (1903-1950), is a man in his midforties who hopes that 1984 will help prevent English socialism from becoming another version of the National Socialism that engulfed Germany and much of Europe. He hopes that forty or so years later, in 1984, when his adopted son Richard Horatio Blair would be about his and Winston Smith's age, England and other countries will still have open, decent societies. And if not, if things were to go in a Stalinist-Soviet direction between 1948 and 1984 and afterward, Orwell nevertheless slips in an indeterminate hopeful note that was brought to my attention by Thomas Pynchon's insightful introduction to a re-edition in 2003 (the first year of the second Iraq War and the year my son Daniel was born).

Pynchon asks a basic question that might occur to any reader of 1984 : "Why end a novel as passionate, violent and dark as this one with what appears to be a scholarly appendix?" Here is his answer:

The answer may lie in simple grammar. From its first sentence, "The Principles of Newspeak" is written consistently in the past tense, as if to suggest some later piece of history, post 1984, in which Newspeak has become literally a thing of the past-as if in some way the anonymous author of this piece is by now free to discuss, critically and objectively, the political system of which Newspeak was, in its time, the essence. Moreover, it is our pre-Newspeak English language that is being used to write the essay. Newspeak was supposed to have become general by 2050, and yet it appears that it did not last that long, let alone triumph, that the ancient humanistic ways of thinking inherent in standard English have persisted, survived, and ultimately prevailed, and that perhaps the social and moral order it speaks for has even, somehow, 
been restored. (...) In its hints of restoration and redemption, perhaps "The Principles of Newspeak" serves as a way to brighten an otherwise bleakly pessimistic ending — sending us back out into the streets of our own dystopia whistling a slightly happier tune than the end of the story by itself would have warranted. (xxiii-xxiv)

This explanation seems plausible, and it got me thinking more about the novel's last sentence: "He loved Big Brother." The standard interpretation, I suppose, is that by his loving Big Brother and renouncing as "false" his memory of being "wildly excited and shouting with laughter" with his mother and sister while playing a board game, the Party has won and what's lost is "the ancient time... when there was still privacy, love and friendship, and when the members of a family stood by one another without needing to know the reason" (35). Yet Pynchon's hypothesis allows one to reread that closing sentence differently. Not "He loved Big Brother," but "He loved Big Brother"-in other words, we, living at the time of the narrating of this tragic love story of Winston and Julia, do not!

The point might be clearer if we substitute different nouns: "In 1848 the French loved Louis-Napoléon Bonaparte," "In 1948 the English loved Clement Attlee," "In 1984 Americans loved Ronald Reagan.” But they don't now - at least not so totally and unquestioningly. Our feelings about these and other charismatic leaders are much more complex and conflicted today than simple love. And one of the reasons may have to do with the portrait of Big Brother and the Party he represents that Orwell bequeathed to future generations, a portrait that he was already teaching us to read critically, discriminatingly, thanks to its juxtaposition with the "ancient time" that we could also call archaic or first, with old customs and habits (mours to use Tocqueville's favorite term) that existed prior to the revolution and the modern revolutionary spirit that is carried on by the Two Minutes Hate, the Thought Police, etc. This Old Regime and "the presence of the past," as Sheldon Wolin would say, have constantly to be beaten down in a society that demands complete orthodoxy, i.e., no critical thinking, no consciousness (61).

But thoughts are constantly cropping up again because there is always more past being produced every day, and thinking can arise from mere succession, the mere juxtaposition of then and now, or of subject and 
predicate. Hence the desire of every totalitarian regime to stop time and control language. Hence too, then, the desire of Winston, the rebel without a cause, to raise his glass of "dark-red liquid"- “'It is called wine,' said O'Brien with a faint smile. 'You will have read about it in books, no doubt" (198) — in a toast "to the past" (204). It also explains his willingness, eagerness even, to affirm, "We are the dead." But surely this is hyperbole, spoken for effect. It would be more accurate to say, "We are the archaic" or "We are dinosaurs" as some professors refer to themselves, since that is what Winston really means-and this is spoken as edgy defiance (against the grain, against the conformist pressure of Ingsoc), at least the first time he says it (156), and O'Brien too (203), and not as deflated resignation as it sounds at the moment of his arrest by the Thought Police (252).

Orwell's 1984 is a nightmare that both retells dreams and is written with the odd logic of dreams that Freud sensitized us to. It is Orwell's answer to Hölderlin's question "Wozu dichter in dürftiger zeit?"-What's a poet to do in hard times? Resist and bear witness. But I am convinced by Pynchon's observations that it is a nightmare from which we are supposed to wake up, like Scrooge, and change our lives. It is inspired writing, inspired, I think, by a variant of the "religious terror" $(D A \mathrm{I}, 6)$ that inspired Tocqueville-terror of the "irresistible revolution" toward equality, and the prospect that if misused, equality would extinguish all meaningful liberty. Orwell, like Tocqueville, worried that socialism, if pushed too far by zealots or fanatics, and if it succumbed to the depraved instead of the manly passion for equality (DA I, 115), would be incompatible with liberty and therefore incompatible with creative development, whether scientific, artistic, or simply existential such as the love between two people or random acts of human kindness to strangersof which Tocqueville was no doubt the grateful recipient in America on many occasions.

"What mattered were individual relationships," says Winston, referring to "the people of only two generations ago" (191), i.e., back in the days before the revolution. "The proles, it suddenly occurred to him, had remained in this condition. They were not loyal to a party or a country or an idea, they were loyal to one another. (...) The proles had stayed human” (191). This may be a slight exaggeration, like Longfellow's 
Blacksmith with his "brawny arms," "strong as iron bands," that seem to have captured Orwell's imagination; nevertheless we get his point: party loyalty can kill loyalty to friends and family. And inversely, affectionate clannishness can lead to suffocating provincialism and cronyism that shut out the discoveries and productivities of networks of weak ties that develop within the massive, moderate middle. What can look like a help can end up a hindrance. "Here comes a candle to light you to bed, here comes a chopper to chop off your head!" (254). Tocqueville could relate to that, since, as Gopnik astutely noted, the question for him was always, "Given that democracy is sure to come, how do you make a democracy that does not turn into a bunch of guys with a guillotine killing all your relatives?" (214) For Tocqueville, as for Orwell, the danger was not so much the establishment of "stupid hedonistic Utopias," as O'Brien calls all previous efforts at social engineering, however regrettable such soft worlds would be, lacking as they do in grandeur, excellence, and selfless courage. The greater danger is the hard-edged world the Ingsoc party seeks to establish:

A world of fear and treachery and torment, a world of trampling and being trampled upon, a world which will grow not less but more merciless as it refines itself. Progress in our world will be progress towards more pain. The old civilizations claimed that they were founded on love or justice. Ours is founded upon hatred. In our world there will be no emotions except fear, rage, triumph, and self-abasement. (306)

This world with its echo of the dark closing of Matthew Arnold's "Dover Beach" is the hard despotism that Tocqueville wanted to avoid at all cost, and I think he and Orwell would pragmatically accept soft despotism's dull vulgarity, if at least now and then-fugitively, as Wolin would say-it left room or made room for love and justice, since out of these liberty and human dignity have a chance to be revived. 


\section{Revisiting Brave New World (1932) and \\ Brave New World Revisited (1958)}

In a gesture that both points out and sidesteps the author's decision to adopt and keep a second identity via a pen name, Simon Leys's review of the "Orwell Diaries" leads off with this affirmation: "Blair's personal life and Orwell's public activity both reflected one powerfully single-minded personality: Blair-Orwell was made of one piece: a recurrent theme in the testimonies of all who knew him at close range was 'his terrible simplicity.' He had the 'innocence of a savage."' ${ }^{339}$ It is worth recalling in this context that Aldous Huxley's anti-hero, his Winston Smith, his barber-tramp, is a bicultural savage later referred to as Mr. Savage. A savage who ends up hanging himself at the end of Brave New World, which was published long before 1984 or 1984 in 1932, and, like Orwell's dystopia, sets its action in a not too distant future. Was Huxley among those who thought Orwell, or at least the mentality evoked in Orwell's 1984, a bit simplistic, savage, and uncivilized?

The Harper editions of Aldous Huxley's Brave New World (1932) and Brave New World Revisited (1958) both reprint in an appendix to the texts a letter that Huxley wrote in 1949 thanking Orwell-Blair for sending him a copy of $1984 .{ }^{240}$ We learn from this letter that Orwell expressly asked his publishers to send a copy to Huxley, who had been his French teacher at Eton. ${ }^{241}$ This strengthens the hypothesis that through the voice of O'Brien Orwell may be taking aim at his former professor's "stupid hedonistic society" portrayed in Brave New World, criticizing presumably the notion that a nonviolent utopian society could be engineered into existence merely on the basis of (1) thorough-going infant conditioning, (2) strict discipline within and between social hierarchies (Alphas, Betas, Deltas, etc.), and (3) the provision of infinite supplies of pleasurable substances (soma) and distractions (feelies) to diffuse tension and occupy one's time. Against this pleasure principle totalitarianism that Huxley depicted during the height of the Great Depression but before Hitler came to power, Orwell offers a pain principle version, one could say. Orwell's ruthless and fearful new world comes directly in the wake of World War II with just enough distance from the multiple violent atrocities of that conflict to make it highly provocative in the early years of the Cold War as the Western democracies and Eastern Communist bloc were 
hardening into a permanent, highly militarized face-off, vying for world dominance and competing for the allegiance of nonaligned countries in the so-called Third World.

Thus, a more gentlemanly, polite rather than political face-off is engaged in between Huxley and Orwell; and of course Huxley will ultimately have the upper hand-having the good health and long life that enabled him to write both before and after the conflicts of the 1930s and '40s which spurred both men to dramatize in novelistic form their thoughts on the threats to democracy and freedom in modern times. But Orwell's visions and mordant language seem to have haunted the older Huxley, and therefore declaring who in the end wins their professor-student dual can only be speculation.

Huxley chides Orwell and his 1984 for being essentially old-fashioned, archaic let's say, because it has the ruling oligarchy rely still on the "policy of the boot-on-the-face." Huxley deems the continuation of such practices "doubtful," because too "arduous" and "wasteful."

My own belief is that the ruling oligarchy will find less arduous and less wasteful ways of governing and of satisfying its lust for power, and these ways will resemble those which I described in Brave New World. (... ) Within the next generation I believe that the world's rulers will discover that infant conditioning and narco-hypnosis are more efficient, as instruments of government, than clubs and prisons, and that the lust for power can be just as completely satisfied by suggesting people into loving their servitude as by flogging and kicking them into obedience. In other words, I feel that the nightmare of Nineteen Eighty-Four is destined to modulate into the nightmare of a world having more resemblance to that which I imagined in Brave New World. The change will be brought about as a result of a felt need for increased efficiency. (BNWR, appendix, 9-10)

Unconvinced, it would seem, by Veblen's 1899 theories about the persistence of drudgery (for the powerless) and the prestige of waste (for the predatory modern leisure class), Huxley accuses Orwell of remaining under the spell of classic totalitarianism, what we've been calling hard 
despotism. In contrast, Huxley sees the menace to human freedom as coming from the soft despotism that Tocqueville imagined in 1840 and that he, Huxley, in a sense expanded on, standing as he is in 1932 on the shoulders of Tocqueville and subsequent commentators (e.g., Gramsci) of at least three additional generations of close collaboration between the social sciences, monopolistic capitalism, and pseudo-democratic or openly authoritarian oligarchy politics.

The God figure in Brave New World, for example, is not a mysterious, mustachioed menace but a heroic prime mover, Henry Ford. Time itself is measured in annual units of "A.F." ("after Ford"), and the revolution is named after the efficient social organization that his career and name are synonymous with: "Fordism." Those who for whatever reason insist on being individuals and not conforming to society's brave new rules are not vanished or reduced through torture to catatonic, zombie-like creatures as happens in the world of Big Brother. ${ }^{242}$ They are merely exiled to faraway islands in Huxley's kinder gentler dystopia. Huxley has citizens in his post-Ford world diffuse any free-floating anxieties and desires through a multitude of pleasure-inducing distractions, whereas in the post-Hitler world Orwell chooses to have his fictional Ingsoc citizens kept constantly on message and in line via group calisthenics for the body and for the mind with the litany of good news about Oceania's superiority, emotionchanneling exercises such as Two Minutes Hate and Hate Week, and of course constant surveillance by video cameras and spies.

Beyond these and other differences in means, however, what is probably most striking to the contemporary reader is how powerfully complementary the visions in these two books are-each successful enough in its own way to have entered vernacular English. We call something "Orwellian" when we want to single out for criticism a piece of harsh authoritarian behavior wrapped in euphemism, such as the use of the term deactivated to characterize the abrupt firing of some tenured professors at the State University of New York at Albany in 2010. ${ }^{243}$ And we call something a "brave new world"-extending Huxley's ironic borrowing of Miranda's wide-eyed declaration in Shakespeare's The Tempestwhen we want to cast doubt on some new attitude or practice that asserts itself in the name of progress and modernity. ${ }^{244}$ In both worlds "history is bunk," 245 and art and science as pure creative inquiry are outlawed, 
as is any individual purpose or private project. One must conform to one's group identity at all times and consistently carry out one's public duties as dictated either by Big Brother and his Party surrogates, such as O'Brien, or in Huxley's world by "Our Ford" and his surrogate Directors and Controllers, such as Mustapha Mond. And live happily, or at least tranquilized, ever after.

Contemporary observers since the days of Orwell and Huxley (who both died during the Cold War in 1950 and 1963, respectively) know that neither soft despotism nor hard despotism has disappeared in the Internet age. On the contrary, both approaches are exercised by openly authoritarian regimes as well as in modern democracies on a regular basis as conditions require. For some there is the "Patriot Act" and "Homeland Security"; for others there is "extraordinary rendition" and "enhanced interrogation techniques." These groups here are held in thrall by targeted advertising, cell phones, smart phones, headphones, and the infinite sources for distraction of the Internet; those groups there are deported or exterminated or else held in place by solitary confinement, detention camps, and other forceful police tactics.

It would seem, though, that for Huxley the differences between hard and soft approaches were important (as we saw they were for Tocqueville), since he felt compelled to elaborate on them further in a more extended reply to Orwell in Brave New World Revisited. In Chapter Three of that follow-up book devoted to "over-organization" and its deleterious effects on freedom and the chances for democracy, Huxley offers a comparison of the ways one might go about imposing a "Social Ethic" on a species, man, that according to Huxley's research is "a moderately gregarious, not a completely social animal-a creature more like a wolf, let us say, or an elephant, than like a bee or an ant" (BNWR, 23). Man's moderately gregarious nature is a core belief of great importance for Huxley.

In their original form human societies bore no resemblance to the hive or the ant heap; they were merely packs. Civilization is, among other things, the process by which primitive packs are transformed into an analogue, crude and mechanical, of the social insects' organic communities. At the present time the pressures of over-population and technological change are accelerating this process. The termitary has come to seem 
a realizable and even, in some eyes, a desirable ideal. (...) However hard they try, men cannot create a social organism, they can only create an organization. In the process of trying to create an organism they will merely create a totalitarian despotism. (BNWR, 23)

Brave New World and 1984 are two imaginary attempts-composed amid plenty of real world twentieth-century experiments - to achieve this reduction of the indocile, freedom-loving wolf-man into the entirely social, tractable ant-man. And Huxley compares the fables two pages later in this paragraph:

It is worth remarking that, in 1984, the members of the Party are compelled to conform to a sexual ethic of more than Puritan severity. In Brave New World, on the other hand, all are permitted to indulge their sexual impulses without let or hindrance. The society described in Orwell's fable is a society permanently at war, and the aim of its rulers is first, of course, to exercise power for its own delightful sake and, second, to keep their subjects in that state of constant tension which a state of constant war demands of those who wage it. By crusading against sexuality the bosses are able to maintain the required tension in their followers and at the same time can satisfy their lust for power in a most gratifying way. The society described in Brave New World is a world-state, in which war has been eliminated and where the first aim of the rulers is at all costs to keep their subjects from making trouble. This they achieve by (among other methods) legalizing a degree of sexual freedom (made possible by the abolition of the family) that practically guarantees the Brave New Worlders against any form of destructive (or creative) emotional tension. In 1984 the lust for power is satisfied by inflicting pain; in Brave New World, by inflicting a hardly less humiliating pleasure. (BNWR, 25-6)

As description this is fine as far as it goes, and it leads Huxley to restate a few pages later the chiding criticism he made to Orwell in his private letter nearly ten years before. Huxley does not rule out that "torture and 
massacre, slavery, and the persecution of heretics" may yet return once again among so-called civilized people, just as they did to general surprise after World War I; but, he affirms, "in the immediate future there is some reason to believe that the punitive methods of 1984 will give place to the reinforcements and manipulations of Brave New World" (BNWR, 31).

And yet history has shown that the advent of software and other soft-serve technologies can take place right alongside harsher traditional methods of persuasion. ${ }^{246}$ It's strange that Huxley didn't foresee this complementary coexistence of carrots and sticks, seductive pulling and coercive pushing. Surely he had heard the expression "speak softly but carry a big stick." It's also strange, since Huxley claims greater verisimilitude for his fable, that he would consider plausible a world-state in which war and want have been eliminated, for both in the 1930s and in the 1950s the global socioeconomic reality was one of scarcity and increasing competition-too many malnourished people chasing too few good jobs. Furthermore, it's Huxley himself who is underlining throughout Brave New World Revisited the tension-producing conditions that lower the chances of democratic practices replacing dictatorships or of enduring in places where democracy has worked up until now thanks to traditions of local cooperation and abundance. Therefore, he's in the awkward position of explicitly claiming that the mechanisms of social control depicted in Brave New World are the wave of the future and yet having to implicitly concede (given the thesis of BNWR) that a state of permanent war over immaterial ideologies and a permanent struggle to possess scarce material resources spread unevenly over an increasingly crowded planet was better intuited in the tripartite, ultranationalistic competitive scenario laid out in 1984.

Brave New World posits "Ten World Controllers" and the existence of uncivilized areas such as the "Savage Reservation" that the malcontent Bernard Marx (Huxley's "Winston Smith”) visits with Lenina (Huxley's "Julia," sort of), but there is no account given as to how this peaceful world-state came about, nor any explanation of how or why the reservations continue to exist, nor why troublemakers like Marx, Mr. Savage, and Helmholtz are merely exiled to islands for individuals instead of being tortured into submission or summarily killed off like Joseph K. or any other undesirable misfit. 
In other words, while the essay Brave New World Revisited might have been partly motivated by a competitive desire to point out some alleged flaws in the work of a famous rival in the field of theoretical-mythicalprophetic utopia studies, ${ }^{247}$ Huxley ends up inadvertently revealing some weaknesses in his own imaginative creation. This fact takes nothing away from the many strengths of the later essay, which offers a persuasive argument about how hard it will be for democracy to take hold or survive in an overcrowded, overorganized world. It also claims that in such a densely organized world it will also be next to impossible for man to remain truly human and pursue projects freely and lovingly in accordance with his fundamental nature and values. Huxley's argument leads one to wonder if democracy is integral to man's preservation of his humanity. Might democracy be best characterized not as a human right, but as a human requirement? Huxley does not explicitly ask those questions though his inquiry leads in that direction. However, he does ask an essential practical question in his concluding chapter entitled "What Can Be Done?"namely, Are humans all that interested in preserving their humanity?

At this point we find ourselves confronted by a very disquieting question: Do we really wish to act upon our knowledge? Does a majority of the population think it worth while to take a good deal of trouble, in order to halt and, if possible, reverse the current drift toward totalitarian control of everything? In the United States - and America is the prophetic image of the rest of the urban-industrial world as it will be a few years from now-recent public opinion polls have revealed that an actual majority of young people in their teens, the voters of tomorrow, have no faith in democratic institutions, see no objection to the censorship of unpopular ideas, do not believe that government of the people by the people is possible and would be perfectly content, if they can continue to live in the style to which the boom has accustomed them, to be ruled, from above, by an oligarchy of assorted experts. (BNWR, 120)

Note the popular "drift" metaphor. Sixty years later, we could wonder what today's opinion polls would report if young people were asked similar questions in post-Mao, post-Deng China or in Putin's Russia, Obama's 
America, Hollande's France, or Cameron's UK, for example. And aren't many Americans and Europeans today saying that the answer to the post-2008 bust that has replaced their boom is not more democracy but stricter discipline, "austerity," and top-down management by experts? ${ }^{248}$

Huxley recommends "Education for Freedom"- the title of his second-to-last chapter-which for him means reaffirming that "without freedom, human beings cannot become fully human and that freedom is therefore supremely valuable." But there is a troubling circularity to this declaration that perhaps will be most quickly picked up on by someone who is malnourished, homeless, uninsured, or unemployed. To them freedom may sound like a luxury they can't afford or just another word for "nothing left to lose" (Joplin). Therefore the burden is on Huxley and those who share his views to demonstrate that freedom is "supremely valuable" and a necessary condition for achieving all primary human needs. If successful, he might gain acceptance for the idea put forward by Tocqueville, Heimonet, and others that "the purpose of life was not well-being but some intensification and refining of consciousness, some enlargement of knowledge" (BNW, 177) — what Tocqueville calls alternately "esprit de liberté" and "esprit religieux," and Heimonet (following Bataille) "le sacré." And acceptance for the related idea of Saussure, as relayed by Barthes, that this "intensification" has to happen with others and imposes limits; an idea relayed in turn by Heimonet when he writes, "Awakening to the consciousness of one's non-sufficiency, the common feature of religion and associations, is no longer only an art but an ethic of limits." ${ }^{249}$ Here is what Huxley says educating for freedom would teach us:

The value, first of all, of individual freedom, based on the facts of human diversity and genetic uniqueness; the value of charity and compassion, based on the old familiar fact, lately rediscovered by modern psychiatry - the fact that, whatever their mental and physical diversity, love is as necessary to human beings as food and shelter; and finally the value of intelligence, without which love is impotent and freedom unattainable. (BNWR, 112)

It sounds like the "Humanities" curriculum of a mostly bygone age that believed in liberal arts education, such as when William James could 
write of "The Social Value of the College Bred" (1907). But how many today are willing and able to enroll in such courses? And who will pay for them? Does a majority of the population think it worthwhile to take a good deal of trouble to stop the current drift toward totalitarian control of everything?

\section{Forster's Democracy: A Room with a View}

If he had been a fictional character in Huxley's Brave New World, E. M. Forster would certainly have been sent off to a faraway island since everything he wrote over his long life (1879-1970) contained "the threat of unorthodoxy" (BNW, 148) and the menace of being true and hence of being banned, like Shakespeare (218), whose archaic quality and strange beauty, says Mustapha Mond, risked making it too attractive and therefore provoking the sort of "deconditioning" that could upset the harmonious, if dull, social state that he and the other World Controllers had managed to engineer into existence.

Forster's indocile writings - his novels, stories, essays, and occasional prose pieces-all defend "the infinity of the private man," his liberty to experiment and invent, and his freedom to engage in loving relationships with people, places, and things. Human life for Forster was "a room with a view," that is to say, a given form that nevertheless held out a prospect for endless renovation and innovation in collaboration with others, living or dead. In Huxley's Brave New World, thoughts such as "Only connect" (the epigraph to Forster's 1910 novel Howard's End) must be censored. Mustapha Mond explains why:

It was the sort of idea that might easily decondition the more unsettled minds among the higher castes-make them lose their faith in happiness as the Sovereign Good and take to believing, instead, that the goal was somewhere beyond, somewhere outside the present human sphere; that the purpose of life was not the maintenance of well-being, but some intensification and refining of consciousness, some enlargement of knowledge. Which was, the Controller reflected, quite possibly true. But not, in the present circumstance admissible. $(B N W, 177)$ 
The total state as depicted in Huxley and Orwell's fables employs engineers of all sorts for purposes of conditioning and control, but neither society can tolerate the artist, the scientist, or the religious mystic since these types of individuals have a tendency to wander off and disobey the state's rules while pursuing their own projects for their own sake with a self-reliant, aristocratic sovereignty. ("Science is dangerous; we have to keep it most carefully chained and muzzled," $B N W$, 225.) The appropriately named Mr. Emerson in Forster's novel A Room with a View (1908) is one such individual and the triumph in that love story is the nudge that gets his son and Lucy Honeychurch to channel their inner Beethoven and connect in the end instead of succumbing to conformist hobgoblins.

Although perhaps tempted by the moralizing tendency of an age that can lead smart, sensitive souls to want to teach and remonstrate (think of Steinbeck's The Grapes of Wrath, 1939), Forster's modesty and ironic touch helped him be less preachy and maintain a somewhat clearer border than either Huxley or Orwell between the narrative mode of his fictions and the declarative mode in his essays. In both genres, however, he is offering a steady, low-key defense of tolerance and other "negative virtues" such as "not being huffy, touchy, irritable, revengeful" (46). Forster, who says he belongs to "the fag-end of Victorian liberalism," speaks out respectfully but firmly in favor of the same "manly courage" Tocqueville extolled and that one finds in earlier British liberals such as Milton (Aeropagitica) and Mill (On Liberty), and Lowes Dickinson, author of " $A$ Modern Symposium, which might be called the Bible of Tolerance" (47). Having the courage to tolerate is the main idea in Forster's short essay on the "very dull virtue" tolerance and its superiority to love when it comes to the decent negotiations of public life.

Forster's essay "Tolerance" is one of sixty-eight pieces written in the 1930s and '40s that he published together under the title Two Cheers for Democracy in 1951, the year after Orwell's death. Collectively they look back with relief that not quite everything was destroyed in Europe during the previous two decades, but with only moderate optimism about what lies ahead as the Cold War begins to harden hearts and minds once again both in- and outside the so-called Free World. The essays collected in that volume, thankfully still in print, are very much "a survivor's tale"to borrow the subtitle of Spiegelman's Maus — a tale told by a sensitive, 
considerate, and plucky aristocratic democrat who is leading by example in ways that recall Tocqueville, i.e., with a measure of indestructible faith in "the strange nature of man" (43), in his wolfish need to live freely and semisocially Huxley might say, and (therefore) with few delusions about the reliability or abundance of human virtue, patience, or intelligence.

Broadcasting from his island, so to speak, at Cambridge University in 1951, Forster concludes his "Prefatory Note" to the volume with these words: "The darkness that troubles us and tries to degrade us may thin out. We may still contrive to raise three cheers for democracy, although at present she only deserves two" (xii). The verb thin out is typical of Forster's prose style, which is both high-spirited and down-to-earth. Never haughty or folksy, he writes as a man speaking to men about common problems of urgency (see "Three Anti-Nazi Broadcasts" or "The Challenge of Our Time"), neglected figures who deserve greater attention (see "John Skelton" or "Henry Thornton"), or misconceptions and mistakes that more careful second thoughts can perhaps set right (see "Jew-Consciousness" or “Art for Art's Sake”).

Unlike Forster's charming novels, many of which were lovingly turned into movies almost twenty years ago now by the generation raised first on bedtime stories and later television, his essays, written for an "age of unrest" (102) and an "Age of Faith" (67), risk falling into neglect despite their intelligence, good humor, and relevance in our attention deficient, restless Internet age marked by increasing isolation and immunity. ${ }^{250}$ Forster recognized the danger of his own oblivion as he contemplated what we've been calling the archaic's challenge to the modern:

$[\mathrm{T}]$ he past, and the creations that derive from the past, are losing their honour and on their way to being jettisoned. We have, in this age of unrest, to ferry much old stuff across the river, and the old stuff is not merely books, pictures, and music, but the power to enjoy and understand them. If the power is lost the books, etc., will sink down into museums and die, or only survive in some fantastic caricature. The power was acquired through tradition. Sinclair Lewis, in Babbitt [1922], describes a civilisation which had no tradition and could consequently only work, or amuse itself with rubbish; 
it had heard of the past, but lacked the power to enjoy it or understand. (102)

Forster's effort in these sixty-eight pieces is to be the passeur, the ferryman. But he insists repeatedly that he is not simply teaching "art appreciation" or curating reverence. He is not defending tradition and the individual talent for their own sakes so much as he is relighting a beacon by testifying to the imaginative achievement and "internal harmony" of the work of art that "stands up by itself" like nothing else in the world, as he says in "Art for Art's Sake" (92). Yet appreciation and testimony and creativity are related, as he notes in "Does Culture Matter?"

The appreciator of an esthetic achievement becomes in his minor way an artist; he cannot rest without communicating what has been communicated to him. This "passing on" impulse takes various forms, some of them merely educational, others merely critical; but it is essentially a glow derived from the central fire, and to extinguish it is to forbid the spread of the Gospel. (106)

At key moments that become turning points in their lives, individuals in Forster's fictions oppose forces of extinction as they come into contact with this "glow derived from the central fire." That is why spiritual connections and personal relationships that induce such spiritual connections with "the central fire" figure prominently in the novels and stories.

Personal relationships are Forster's starting point in the essay "What I Believe," which begins, "I do not believe in belief. But this is an age of faith, and there are so many militant creeds that, in self-defense, one has to formulate a creed of one's own" (67). In hard times, even poets must account for themselves. This passionate and lucid act of self-defense against militant creeds, composed, I imagine, like Tocqueville's masterpiece out of "a sort of religious terror," and published in the decisive year 1939, could be considered the keystone to the whole volume and is the source for the expression "two cheers for democracy" that he used for its title. This is an apt summary of Tocqueville's assessment of democracy too: a set of orderly but open relations that produces a more just and confident form of society than what Forster calls "efficiency regimes," but one that is also wasteful, reckless, vulgar, and often ruthless toward 
nonconformists who may (at a price) resist the "salutary yoke" imposed by the tyrannous majority. ${ }^{251}$ For Forster the real advantages of democracy are easily summarized:

[Democracy] is less hateful than other contemporary forms of government... It does start from the assumption that the individual is important and that all types are needed to make a civilization... It does not divide citizens into the bossers and the bossed-as an efficiency regime tends to do... It allows criticism, and if there is not public criticism there are bound to be hushed-up scandals... So Two Cheers for Democracy: one because it admits variety and two because it permits criticism. Two cheers are quite enough: there is no reason to give three. Only Love the Beloved Republic deserves that. (69-70)

The last remark is Forster's dry mock at the sort of unthinking patriotism that Tocqueville and Orwell both derided as being limiting and of limited usefulness. The reason democracy cannot get three cheers from Forster is perhaps most clearly stated in the essay "The Challenge of Our Time" (1946). It has to do with his preference for the individual over a mystic faith in "the people," or as Orwell has Winston Smith say, "the proles." His respectful but firm reservation about the people - the demos-is worth quoting at length:

Temperamentally, I am an individualist. Professionally, I am a writer, and my books emphasize the importance of personal relationships and the private life, for I believe in them ....

If we are to answer the challenge of our time successfully, we must manage to combine the new economy and the old morality. The doctrine of laisser-faire will not work in the material world. It has led to the black market and the capitalist jungle. We must have planning and ration books and controls, or millions of people will have nowhere to live and nothing to eat. On the other hand, the doctrine of laisser-faire is the only one that seems to work in the world of the spirit; if you plan and control men's minds you stunt them, you get the censorship, the secret police, the road to serfdom, the community of slaves. Our economic planners sometimes laugh at 
us when we are afraid of totalitarian tyranny resulting from their efforts - or rather they sneer at us, for there is some deep connection between planning and sneering which psychologists should explore. But the danger they brush aside is a real one. They assure us that the new economy will evolve an appropriate morality, and that when all people are properly fed and housed, they will have an outlook which will be right, because they are the people. I cannot swallow that. I have no mystic faith in the people. I have in the individual. He seems to me a divine achievement and I mistrust any view which belittles him. If anyone calls you a wretched little individualand I've been called that-don't you take it lying down. You are important because everyone else is an individual tooincluding the person who criticises you. In asserting your personality you are playing for your side.

That then is the slogan with which I would answer, or partially answer, the Challenge of our Time. We want the New Economy with the Old Morality. We want planning for the body and not for the spirit. But the difficulty is this: where does the body stop and the spirit start?

... Suppose you are planning the world-distribution of food. You can't do that without planning world population. You can't do that without regulating the number of births and interfering with family life. You must supervise parenthood. You are meddling with the realms of the spirit, of personal relationships, although you may not have intended to do so. And you are brought back again to that inescapable arbiter, your own temperament. When there is a collision of principles would you favor the individual at the expense of the community as I would? Or would you prefer economic justice for all at the expense of personal freedom? (55-58)

There is much to notice here: first, the allusion to Tocqueville via Hayek's borrowing for the title of his instantly popular libertarian essay The Road to Serfdom (1944); second, the concern Forster shares with Huxley about overpopulation and how large global problems and the urge to solve them via regulation can lead to overorganization that in 
turn leads to an arrogant oligarchy of experts who endanger democracy insofar as they stifle freedom and hem in the participation of individuals who are lectured that "there is no alternative" to the dominant viewpoint and the public policy that logically follows from it; and third, the pointed rejection of any romantic idealization of "the people" as inherently virtuous - a matter he returns to in his essay "George Orwell" (1950), which directly follows this one, where he assumes that Orwell ("a bit of a nagger") shared Winston Smith's belief in "the proles." Forster adds, "He also believes in 'the people,' who, with their beefy arms akimbo and their cabbage-stalk soup, may survive when higher growths are cut down. He does not explain how 'the people' are to make good, and perhaps he is here confusing belief with compassion" (62). But perhaps here Forster has confused Blair-Orwell with the narrator of 1984 .

Rhetorically, the most striking features of the passage are the connective apostrophes to the reader ("you," "your") and the interrogative mode at the end that requires each of us to truly think about and take responsibility for the consequences of a decision that will be based not on pure reason or calculation but on temperament-a table-turning strategy that recalls William James's use of temperament to dislodge rationalist logic in his manifesto Pragmatism (1910). Forster's description of the dilemma and his submission of a true open question to the reader also recall the end of Tocqueville's "Real Advantages of Democracy" chapter (DA I, $2,6)$, where after many apostrophes he essentially asks, "What kind of a society do you want? We have to get clear on that" ("Que demandezvous de la société et de son gouvernement? Il faut s'entendre")—if you want features $a, b, c$, don't pick democracy; but if you want $x, y, z$, then do pick democracy. In both there is a voice that says, "We're in this together."252

Ultimately, Forster's "two cheers for democracy" is his attempt to get around the "collision of principles" and the dilemma of mutual exclusion (and the danger of mutually assured destruction), by substituting an "aristocracy of the sensitive, the considerate and the plucky" for the third cheer that is rendered impossible (as it was already for Tocqueville) by the tyranny of the majority and all the other negative tendencies of democracy-notably individualism that runs toward egotism and opens the way toward oligarchy by experts; materialism that runs toward frenzied overconsumption and indebtedness; and nowism that leads to 
contempt for the past and no vision (or taking on of responsibility) for the future. Forster would rather pin his hopes on the leaven provided by the members of his plucky aristocracy rather than on the people's uncertain goodness or the wisdom of technocratic consultants brought in from the social sciences and schools of management to advise and administrate. ${ }^{253}$

Nevertheless, the aristocracy he describes is democratic in the sense that its members crop up everywhere and all stand in opposition to the traditional hero-worship (especially the worship of power, rank, and influence) that comes with traditional aristocracy. "Its members are to be found in all nations and classes, and all through the ages, and there is a secret understanding between them when they meet" (73); they behave a bit God-like, "as if they were immortal and as if society was eternal" (71); what is good in these people is "their insistence on creation, their belief in friendship and loyalty for their own sakes" (72); and "such people get more of a chance under a democracy than elsewhere" (69). These individuals express something spiritual, but in a non-Christian form that Forster finds preferable (as it avoids church hierarchies with their money-soaked pyramids of power, secrecy, and hypocrisy), which is why he concludes by distinguishing his position from that of traditional Christian believers who "have Faith with a large F. My faith has a very small one, and I only intrude it because these are strenuous and serious days, and one likes to say what one thinks while speech is comparatively free: it may not be free much longer" (76). Forster feels the urgency of bearing witness. He is the consummate professor-artist who accepts that no one ought to duck accountability, and so like Shelley before him, he defends his actions and those of his tribe, hoping that society will in turn remember its duty to artists and not banish or kill them off completelyhardly a groundless fear in 1939.

\section{$\phi$}

In 2011 the British publisher Penguin celebrated the fiftieth anniversary of its popular series Penguin Classics by putting out a set of low-cost, pocket-sized Mini Modern Classics that included a volume containing two Forster stories, "The Machine Stops" and "The Celestial Omnibus." The latter had been the title story of an anthology I read more than thirty 
years ago, but it was "The Machine Stops" that got top billing for this reedition, and it's easy to see why. Market analysts at Penguin, who perhaps noticed that technology skeptics and other Zeitgeist watchers of the Internet age responded favorably to Jaron Lanier's 2010 manifesto You Are Not a Gadget, may have intuited that they could attract a similar group of readers with a slim volume hardly bigger than an iphone that features Forster's 1909 "meditation" on a gadget-filled world that gradually comes to enslave the minds and bodies of its human inventors. Forster imagines a world where people live underground like bees in cells because the surface of the earth has become uninhabitable or is said to be so, and they communicate as much as possible indirectly_direct contact being shunned as vulgarly "unmechanical"-via "blue optic plates." Decades before "The Jetsons" or Skype, Forster imagined the video call.

But it was fully fifteen seconds before the round plate that she held in her hands began to glow. A faint blue light shot across it, darkening to purple, and presently she could see the image of her son, who lived on the other side of the earth, and he could see her. (2)

Change the circle to a rectangle and Forster could be describing a contemporary conversation on any computer screen. Other gadgets and dry comments in the story are likely to hold the post-9/11 Internet age reader's attention, right up to the "air-ship" that crashes into a building at the cataclysmic end of the story.

The mordant irony of this short story starts out from a simple motherson "communication gap" in a posthuman world. ${ }^{254}$ But instead of casting the boy as the hip technophile and the mother as the square technophobe, it is just the reverse. The son asks his mother to come and see him. "Vashti watched his face in the blue plate. 'But I can see you!' she exclaimed. 'What more do you want?' 'I want to see you not through the Machine,' said Kuno” (3). Acting on some vestige of maternal instinct, she travels to meet with her son and listens as he tells her more heretical ideas: "The Machine is much, but it is not all ... Cannot you see, cannot you lecturers see, that it is we who are dying, and that down here the only thing that really lives is the Machine." He then recounts his daring escape to the surface of the earth; informs her of the Central Committee's 
threat to sentence him to "homelessness"; and most importantly makes the "venomous" remark, "The Machine stops" (45).

Signs of "the collapse of humanity" (48) multiply in the third act of the story, entitled "Homelessness," until eventually "the Committee of the Mending Apparatus" "confessed that the Mending Apparatus was itself in need of repair" (49). However, the repairs are not forthcoming, and this Machine civilization comes to an apocalyptic end. But in extremis, Forster has Kuno voice the revolutionary credo that the earth will be repopulated by a new Humanity of wised up "Homeless" people.

"I have seen them, spoken to them, loved them. They are hiding in the mist and ferns until our civilization stops. Today they are the Homeless - to-morrow-"

"Oh, to-morrow-some fool will start the Machine again, to-morrow."

"Never," said Kuno, "never, Humanity has learnt its lesson."

As he spoke the whole city was broken like a honeycomb....

Note the echoes from that magical play of misguided statecraft, Macbeth: "mist... to-morrow... fool." Shakespeare seems to have been hardwired into British brains in those days. Note also that whatever the outcome might be in the play beyond the play, so to speak, Kuno has managed to get through to his mother, since it is she who calls the one who might start the Machine again a "fool." This and other subtly hopeful characteristics of the story ("Is there any hope, Kuno?" "None for us.") may have led Huxley and Orwell to use Forster's "meditation" as a template for their own mythopoetic utopia studies. At any rate, the sales and marketing people at Penguin books would probably be glad if more of us would like to make use of it ourselves.

\section{Missing Tony Judt's Anger}

As a recipient of the Orwell Prize and as a former student of Forster's at Cambridge University, it seems fitting to close out this tour of prominent, interrelated 1930s British witnesses of democracy and dictatorship with the "audit" carried out by the British-born cosmopolitan historian Tony Judt. He was born in 1948 (like Heimonet and Pierre Rosanvallon), 
which makes him a sort of early baby boomer just as President Obama, born in 1961, is the symmetrical late baby boomer. Being born on or near the point of articulation between two periods or generations is perhaps more conducive to becoming the sort of privileged witness or "edge person" that Judt identifies himself with. Judt's name suggests both jutting out and judge, two features that happen to characterize his somewhat "edgy," against-the-postmodern-grain assessments of the topics he treated in his many books and essays. He died in August 2010 of the motor neuron disease ALS - amyotrophic lateral sclerosis - also known in the U.S. as "Lou Gehrig's disease" in memory of a famous baseball player who died of ALS in 1941. In France it is known as the maladie de Charcot, in honor of Jean-Martin Charcot, the doctor who first diagnosed it in detail-the same doctor whose work on hysteria and hypnosis would influence Freud and the development of psychoanalysis. In the last two years of his life, as he was progressively losing power over his body from limbs to core, Judt managed to write two fine little books. One is an extended essay on the rise and fall of social democracy and the possibility of its afterlife. The other is a selection of shorter pieces on heartfelt topics that are linked together, like the Swiss train cars moving through a wintry landscape depicted on the book's cover, by the warmth and intelligence of Judt's lively mind. Their titles are Ill Fares the Land (2010) and The Memory Chalet (2010). ${ }^{255}$

One has to marvel at the extraordinary courage and determinationcomparable to that of Stephen Hawking or Jean-Dominique Bauby-of someone undertaking and actually completing these projects. And at the combination of generosity and stubbornness that seems to have pushed Judt to write to the end where lesser figures with already a shelf of publications to their names might have occupied their last days sailing or fly fishing. But of course those latter activities, while possible for the cancer patient, say, are not options for the ALS patient, who instead finds himself unexpectedly entombed in the cell of his own body, an odd plot twist that even Poe had not imagined, though Forster in "The Machine Stops" came close.

There are no doubt plenty of reasons that justify awarding Tony Judt the Orwell Prize (2009) and the Hannah Arendt Prize (2007), but I would like to create and bestow on him an "E. M. Forster Prize" 
for "enterprising curiosity, an undefeatable spirit, tenacity in pursuit,"256 and optimism in the face of a depressing set of crises at every level starting with his own personal condition (advancing paralysis, terminal illness) and moving out to that of his professional life as a contemporary humanities professor (reduced social honor amid a new "counterenlightenment"257) and then to the world at large (austerity, scarcity). Despite the high seriousness of his historical essays, Judt's true temperament may have been closer to Forster's. Judt is irrepressibly cheerful-just look at that endearing smile on the back flap of his two last books - and lacks the anger of an Orwell or Heimonet, though he wishes he and his colleagues could be angrier.

In his Introduction to 1984 discussed above, Thomas Pynchon says that Orwell was constantly worried about losing the anger that seems to have been his fuel, his spur. In Ill Fares the Land, Judt seems worried about not finding his - not being able to adequately express his anger or incite an anger in his contemporaries that would be productive and not destructive. Perhaps, like many, he is undecided about the value of anger and wonders whether it is best to let it out or hold it in. ${ }^{258}$ Unlike the Memory Chalet, which is Judt's Forster-like "Harvest," Ill Fares the Land is supposed to be the Orwell book, a jeremiad in the tradition of Politics and The English Language (1946) written under the twin signs of lamentation and anger, and yet the anger is mostly muted or missing despite repeated invocations.

There is much to be angry about (8)... "you speak of being angry at our political quiescence" (9)... This is not to say that a new generation of radicals was insensitive to injustice or political malfeasance: the Vietnam protests and the race riots of the '60s were not insignificant. But they were divorced from any sense of collective purpose, being rather understood as extensions of individual self-expression and anger (90)... Liberation is an act of the will. We cannot hope to reconstruct our dilapidated public conversation-no less than our crumbling physical infrastructure-unless we become sufficiently angry at our present condition (161)... Incremental improvements upon unsatisfactory circumstances are the best that we can hope for, and probably all we should seek. Others have 
spent the last three decades methodically unraveling and destabilizing them: this should make us much angrier than we are. (224, emphasis added)

The above instances of the words anger, angry and angrier suggest that on the one hand Judt believes in the role of anger as a catalyst of consciousness-raising and political action, but he is also perhaps mindful of the possibility of (1) its degeneration into tantrum and sterile self-indulgence, (2) of not getting beyond that primary gut feeling of pain and hurt, and (3) of its escalating out of control. In other words, three counterproductive outcomes. For anger to be more than mere "venting," he knows that it must be articulate, it must be backed up by well-crafted arguments (claims based on reasons and evidence that acknowledge objections and alternative views and respond to them), and it must be in the service of some "collective purpose" and not pursued for its own sake.

Having been twenty in 1968 and not six, sixteen, or thirty-six, Judt was in a better position than many to both take part in and see the limitations of various forms of protest in Europe, America, and Israel around that time. ${ }^{259}$ The possibility of one's anger being insufficiently articulate and articulated to larger aims, and therefore mocked and dismissed as childish tantrum and irresponsible pique-as David Brooks does to the Occupy Wall Street movement ${ }^{260}$ — is probably what makes Judt repeat (even more times than the word angry) his belief that what's seriously lacking is the proper way of talking about our current social maladies.

That the one groping for a proper diagnosis of the "ill" "land" is an ill man dying of a mysterious motor-neuron disease for which there is currently no cure adds poignancy to the whole enterprise. One should also keep in mind that both these farewell books are dedicated to Judt's teenage sons by a third younger wife (i.e., he knows whereof he speaks when talking about "divorced from any sense of collective purpose"). In other words, they attempt the grand écart of combining a certain insouciance with a deathbed admonitory dimension: try and avoid the mistakes made by me and mine (including excess insouciance). As another Englishman who knows his classics, Judt channels his inner Shakespeare (via Oliver Goldsmith) and throws a bit of updated King Lear and John of Gaunt (Richard II, “...this sceptered isle...”) into his original remix of empire anxiety and declinist talk. Understandably, he wants his heirs to avoid 
being a part of another "Lost Generation" and to avoid if possible the mass suffering that his own parents experienced in the 1930s.

But do we have here a case of the blind leading the blind? Or is it instead that in the world of the blind, the one-eyed are worth following for a while at least? Judt knows that the historian, like the economist or philosopher, must neither exaggerate nor minimize the value of his contribution to the public debate, and he's often straining to follow his own prudential advice. This is noticeable in the large number of pointed but polite questions and repeated calls for better talking. Here are some examples:

If 1989 was about re-discovering liberty, what limits are we now willing to place on it? Even in the most "freedom-loving" societies, freedom comes with constraints. But if we accept some limitations-and we always do-why not others? Why are we so sure that some planning, or progressive taxation, or the collective ownership of public goods, are intolerable restrictions on liberty; whereas close-circuit television cameras, state bailouts for investment banks "too big to fail," tapped telephones and expensive foreign wars are acceptable burdens for free people to bear?

There may be good answers to these questions; but how can we know unless we pose them? We need to rediscover how to talk about change: how to imagine very different arrangements for ourselves, free of the dangerous cant of "revolution." (152-153)

Here we see that Judt's anger is most articulate in the interrogative mode. He wants to be a catalyst, leading by example by asking the questions others have forgotten or forgotten how to ask. But the number of repeated calls for better talk suggest that better questions are not enough-good answers or at least "good enough" answers will also have to be formulated and translated into action. Like someone who remembers a past experience of being burned, bitten, or stung, Judt is less inclined to go in that more explicit direction, so he mostly stays in the comfort zone familiar to the tenured Anglo-Saxon college professor, asking questions and calling for better talk: 
Something is profoundly wrong with the way we live today... We know what things cost but have no idea what they are worth. We no longer ask of a judicial ruling or a legislative act: is it good? Is it fair? Is it right? Will it help bring a better society or a better world? Those used to be the political questions, even if they invited no easy answers. We must learn once again to pose them. (1-2) ... Our problem is not what to do; it is how to talk about it. (6) ... "What is most striking", she wrote, "about what you say is not so much the substance but the form ... No one talks like this any more." Hence this book. (9) ... Our disability is discursive: we simply do not know how to talk about these things any more. (34) ... We need to rediscover how to talk about change: how to imagine very different arrangements for ourselves, free of the dangerous cant of 'revolution'. (153) ... [T] o recast our public conversation-seems to me the only realistic way to begin to bring about change. If we do not talk differently, we shall not think differently. (171) ... We need to re-open a different sort of conversation. We need to become confident once again in our own instincts: if a policy or an action or a decision seems somehow wrong, we must find the words to say so. (173) ... Much of what is amiss in our world can best be captured in the language of classical political thought: we are intuitively familiar with issues of injustice, unfairness, inequality and immorality - we have just forgotten how to talk about them. Social democracy once articulated such concerns, until it lost its way. (234, emphasis added)

"Our problem is not what to do; it is how to talk about it." Our problem? That may be the problem for a paralyzed professor or professorate, but surely the problem for some of us is precisely what to do, no?

But what if we go along, take Judt at his word, and ask How good is he at following his own advice and talking the talk that he recommends to others? The answer is, Only so-so. Judt does a fairly good job at retelling the story of social democracy's rise during the postwar years (Keynes, Beveridge, Attlee) and of the "ironic legacy of the '60s" (i.e., how advocates for more civil rights and individual freedoms became accomplices 
in the neoliberal, neoconservative resurgence that led to economic unfreedom, surveillance, and "the cult of privatization"). ${ }^{261} \mathrm{He}$ also usefully names the Austrians (Drucker, Hayek, Popper, Schumpeter, Von Mies) who were instrumental or instrumentalized in dismantling social democracy's egalitarian gains in the name of a dubious "freedom to choose" (Ill, 91-106) — in part by seizing on some bad plans (e.g., eugenics, shoddy low-income housing) to condemn all public planning and subsidized public services. He also does a good job (Ill, 106-19, Memory, “The Green Line Bus," 57-63) at recounting with specific facts and figures the disastrous consequences of the sell-off of British public assets such as the railroad and bus lines, transactions that set the pattern for the privatization of profits and the socialization of risk that has only lately been denounced since the 2008 bailout of U.S. banks and the similar caving in to the "bankster" logic of "too big to fail" in the European bank crisis that intensified in 2011. ${ }^{262}$

For the most part, however, naming names is not Judt's strong suit, and instead of answering precisely a worthy question, "What's living and what's dead in social democracy?" (the title of his concluding chapter), he tends to fall back on vaguely worded condemnations or zingers like this remark that concludes the introduction to Chapter Four, "Goodbye to All That?": "The years from 1989 to 2009 were consumed by locusts." Maybe, but who exactly are the locusts Judt has in mind? The reader is left to guess and may feel angry at Judt for his silence instead of at the postCold War, Internet age "locusts." It would have been more helpful-i.e., stand a better chance of advancing Judt's desired aim of channeling anger for a worthwhile collective purpose - if he had been less biblical here and more bibliographic. ${ }^{263} \mathrm{Judt}$ names none of the principal players in the financial crisis of 2008 (Bernanke, Geithner, Greenspan, and Paulson on the government side, sort of; as well as Joseph Cassano [AIG], Dick Fuld [Lehman], Ken Lewis [Bank of America], Daniel Mudd [Fannie Mae], and Robert Williamstad [AIG] on the corporate side); nor does he steer the reader toward any useful summary of the 2008 crash and bailout such as the documentary films American Casino (2009) and Inside Job (2010) or the ongoing investigative coverage of those events in the New York Times, the New Yorker magazine, or the New York Review of Books, where Judt was a regular contributor. ${ }^{264}$ Judt's silence lets everyone off 
the hook—no account, no accountability—and the image of "locusts" naturalizes a man-made disaster by substituting a narrative of inscrutable cyclical forces that just happen.

The silence and holes, which any research assistant could have filled, weaken Judt's presentation, which falls back on passive, no-fault accounts of social democracy's demise ("it lost its way") and on vague metaphors such as "dismantling" and the even more regrettable (because misleading) metaphor of "unraveling" $(13,44,79,142,224)$ to describe what would be more accurately characterized as a hijacking. "Unraveling" is not the mot juste to describe the deliberate unmaking, by lawmakers not seamstresses or naughty kittens, of the American and British versions of social democracy during the thirty years since the hostile takeovers that accelerated during the years of Reagonomics and Thatcherism. That the cause and effect relationships that led to the transformation of the social state into the security state are not entirely clear in Judt's head seems evident from his mixed metaphors in the following sentence, where the passivity and accidental nature of unraveled fabric conflict with the activity of deliberately taking something apart piece by piece: "By eviscerating public services and reducing them to a network of farmed-out private providers, we have begun to dismantle the fabric of the state" (119). Dismantle the fabric? Orwell would wince.

Judt is just not adversarial enough to get angry or effectively trigger the productive anger that could catalyze the new discourse about social ends and means that he repeatedly calls for. Other symptoms of this disconnect between what he says he wants and what he does include a defense of dissent without naming dissenters ("The Case for Dissent," 156-166), and a frequently naive and/or misleading "we" (such as in the sentence just cited) despite what he knows to be a divided, conflictridden civil society (in the U.S., the UK, and Europe) with less and less consensus and solidarity on very basic matters such as education, housing, health care, and tax policy. In one instance Judt shows he can strip off the wallpaper $W e$.

... It has become commonplace to assert that we all want the same thing, we just have slightly different ways of going about it. 
But this is simply false. The rich do not want the same thing as the poor. Those who depend on their job for their livelihood do not want the same thing as those who live off investments and dividends. (168)

Exactly. So then why does Judt say on page 119 "we have begun to dismantle the fabric of the state"? And why assert that "We are all democrats today"? (emphasis added). There has always been strong opposition to democracy coming from many quarters, including from some Democrats. And certainly some people have been more active and motivated when it comes to dismantling social democracy than others, and many have opposed the dismantling, albeit mostly unsuccessfully. ${ }^{265}$ Furthermore, the state as a whole is not being dismantled, only the social state that for a few decades (roughly 1940-1980) reduced inequalities that had built up during the century after the publication of Democracy in America. In the last thirty years the state has only gotten bigger and more entangled in the economy under the stewardship of oddly named "conservative" politicians who profess to be opposed to "big government." The social security state is weaker than it was thirty years ago, but the security state (i.e., the highly militarized surveillance state of Superpower that Wolin calls "managed democracy" and "inverted totalitarianism") became stronger than ever between 1989 and 2009. Talking about locusts—as though the sins were limited to overconsumption and "bumbling" (162) — obscures the extent of the deliberate, calculated damage to American democracy and other would-be democracies over the past thirty years, and it lets the hijackers off the hook, hidden in the wooly prose of a "great unraveling."266

It is similarly bewildering to see Judt trust in the good instincts of "young people in the United States and elsewhere" (186) when earlier he had used Camille Paglia (85) and his own youthful memories to underscore the fact that his generation's exaggerated individualism and youth worship made him and his self-styled progressive peers complicit in the right's unmaking of social democracy ("The Ironic Legacy of the 60s," 85-91). Oddly, he can ignore the way to hell paved by his generation's supposedly good intentions and claim with apparent sincerity that "the perennial desire of youth to do something 'useful' or 'good' speaks to an instinct that we have not succeeded in repressing." Ironic legacy indeed. Channeling his inner Rousseau, Judt wants the reader to overlook once 
again that problematic "we," believe in such a universal instinct for good, and go along with the unproven claim that "selfishness is uncomfortable even for the selfish" (186). Judt sees the rise of gated communities as evidence of this discomfort; yet one could argue, on the contrary, that the construction of such exclusive and excluding living arrangements and other similarly carefree, callous behaviors prove just how comfortable many wealthy people are inside their selfish "lifestyle enclaves."267

In the book's penultimate paragraph Judt asks, "But were my students of the 1990s and after truly selfish?" With "Business" as far and away the most popular major in American colleges and universities, ${ }^{268}$ the answer would seem obviously to be "Yes"; but for Judt the question is concentrated on that adverb truly, and he seems ready to let his students off the hook too by suggesting they became selfish and money-obsessed from bad parenting or bad television broadcasts. He answers his own question this way:

Assured from all quarters that radical change lay in the past, they saw around them no examples to follow, no arguments to engage and no goals to pursue. If the purpose of life as lived by everyone you see is to succeed in business, then this will become the default goal of all but the most independent young person. (237)

Independent-minded like Thoreau or independently wealthy like the Astors? But there were plenty of arguments-in Milton's senseto engage young people in the roaring 1990s: the skyrocketing cost of higher education, health care, and health insurance; the deindustrialization and financialization of the American economy with downsizing, offshoring, and casualizing of the workforce; the unmaking of unions; the privatization and higher riskiness of retirement plans; the rewriting of the tax code to favor the very wealthy; and of course a dozen major environmental emergencies from global warming to overfishing. With these examples of "radical change" staring them in the face, young people truly saw no goals to pursue other than selecting business instead of English, history, political science, biology, physics or engineering as their college major? Whether the youth of twenty years ago, now in their early forties with children of their own, were truly selfish or instead more sinned 
against than sinning is a question that perhaps only a dying academic, or academy, would ask.

And someone who had not read his Tocqueville well enough. Democracy in America is constantly wondering how rational patriotism, i.e., the simultaneously disinterested and interested communal spirit necessary for good governance and treating common affairs in common, will be able to survive in democratic lands when everyone is relatively weak and therefore restless and nervous about securing their well-being. Individualism and clannishness are rational behaviors in democratic ages, but he knew they could lead to social pathologies. Democracy favors self-reliant banding together of the like-minded but can also trigger selfishness and with it the possibility of disbanding and disconnecting-especially as commerce and industry are allowed to become more sophisticated, specialized, and hypercompetitive. Democracy's looser horizontal relations can nurture community spirit or just as easily kill it off. See Shakespeare's King Lear, or Democracy in America II, 2, 16, "How Excessive Love of Well-Being Can Impair It” (G638).

Interestingly, Tocqueville comes up three times in Ill Fares the Land, but mostly in the form of mild Tocqueville sauce (a cold lead-off epigraph on the first page and a second one on page 29-both without references). ${ }^{269}$ The third mention (157) is somewhat more helpful since it occurs within Judt's "Case for Dissent" and alludes (also without page reference) to the famous passage from $D A I, 2,7,354$, where Tocqueville condemns the soft despotism of the majority in democratic lands that can allow token dissidents - an Emerson, a Thoreau, a Judt? — to live on, entombed and largely powerless at the mercy of the tyrannous majority:

But the balance, noted by Alexis de Tocqueville among many others, has long since swung towards conformity. Individuals remain free to say what they wish; but if their opinions cut athwart those of the majority they will find themselves outcast. At the very least the impact of their words will be muted. (157)

Presumably we are to read those words with sympathy for the professor who is himself slipping into muteness. But what if it's for the best? Of course I don't mean Judt's untimely death, which is genuinely tragic; but 
instead his half-wise, half-foolish valedictory address with echoes of King Lear that are more subtly provocative for being most likely quite unintentional. Again the irony of unintended consequences.

Judt's memoir, like Thoreau's Walden, has been addressing "poor students," but Judt lacks the irreverent self-deprecation of a Thoreau or Forster, nor does he have the anger of an Orwell, and therefore he can't bring himself to add any crotchety aside about the possibly limited practical usefulness of his address as the thirty-seven-year-old Thoreau managed to do in his opening chapter "Economy":

Perhaps these pages are more particularly addressed to poor students. (...) Practically, the old have no very important advice to give the young, their own experience has been so partial, and their lives have been such miserable failures, for private reasons, as they must believe; and it may be that they have some faith left which belies that experience, and they are only less young than they were. I have lived some thirty years on this planet, and I have yet to hear the first syllable of valuable or even earnest advice from my seniors. $(4,9)$

Thoreau could also have entitled his book Ill Fares the Land-Oliver Goldsmith was available for him too-but he didn't; and he didn't end his fundamentally joyful memoir like Judt did with a lame covert allusion to Marx's Theses on Feuerbach (1845) or to any other authority. Thoreau followed Emerson's advice, but not his example, and came up with his own original relation to the universe, signing off with the declaration "The sun is but a morning star." In so doing he in effect performed, precisely through an act of creative interpretation, a kind of change. With that declaration a new perspective, a new outlook on something very old gets invented-and a renewed connection for a new age between man and his world is offered to us, his students.

What I want to say is that in 2010 Tony Judt may still have had a bit too much 1960s self-indulgence for his own good or that of his reader. And yet his heart is in the right place at many junctures in these two memoirs, or at least it seems so to me. One sign of Judt's compassionate fellow feeling comes through with the charts and graphs he makes use of to clearly illustrate the disastrous social consequences of extreme 
inequality: lower social mobility and life expectancy and higher rates of crime and mental and physical illness (16-20). Another notable instance is what he has to say about playing fields (206) and railroads (207-216) as examples of collective public goods that need to be cherished if societies are going to reclaim a political and social role for the state-one that opens windows of opportunity for its citizens that its current missions as cop and blackmailed financial backer of last resort do not achieve. Judt also speaks Tocqueville's language when it comes to the "good and ill" of individualism:

We too readily assume that the defining feature of modernity is the individual: the non-reducible subject, the freestanding person, the unbound self, the un-beholden citizen. This unattached individual is favourably contrasted with the dependent and deferential subject of the pre-modern world. There is something to this account: "individualism" may be the cant of our time but for good and ill it speaks to the connected isolation of our wireless age. However, what is truly distinctive about modern life is not the unattached individual. It is society. More precisely civil—or (as the 19th century had it) bourgeois-society. (215)

Ultimately, the wish for a civil society-one composed of decent, courteous, tolerant citizens who respectfully grant equal dignity and other basic human rights to all and protect them whenever necessary-is what links Judt to his 1930s forebears Chaplin, Orwell, Huxley, and Forster... and to Tocqueville, our common 1830s ancestor, and before him to the American framers in the 1780s, and their British and European sources of inspiration and guidance (Hobbes, Locke, Montesquieu, Rousseau, Ferguson, etc.). From Jefferson to Judt, we are all flawed contradictory individuals, neither angels nor devils, neither exactly wolves, ants, or bees, but men and women, and therefore animated by common human concerns during "a time of troubles" (Memory, 207), including the hope that democratic courage and tolerance continue to be able to repair mistakes and allow each individual, whether singly or in groups, to pursue new opportunities under the rule of law, with liberty and justice for all. 


\section{Notes}

231. Currently seventeen countries use the single currency of the "eurozone": Austria, Belgium, Cyprus, Estonia, Finland, France, Germany, Greece, Ireland, Italy, Luxembourg, Malta, the Netherlands, Portugal, Slovakia, Slovenia, and Spain.

232. See, for example, Joe Nocera, “The 1930s Sure Sound Familiar," New York Times, October 14, 2011. Nocera observes similarities between America in 2011 and 1930s America as described in the 1940 book Since Yesterday by Frederick Lewis Allen. See also Alain Duhamel on the resurgence of far-right politics in France, "Marine Le Pen: Le retour aux années 1930," Libération, March 31, 2011. See also the prescient comparative study by Joseph E. Stiglitz, The Roaring Nineties (New York: Norton, 2004).

233. Conditions looked similarly unsustainable to Tocqueville when he told his fellow deputies in 1848 "We are living on top of a volcano." He implied that no one would profit from an eruption, but Wolin and others (e.g., Naomi Klein in The Shock Doctrine: The Rise of Disaster Capitalism [2007]) are claiming that present day instabilities and terror capitalism are in fact desired and engineered by the "inverted totalitarianism" of Superpower.

234. The 2012 film The Dictator by Sacha Baron Cohen of "Borat" fame is a noteworthy attempt to treat similar themes. See David Denby's mixed review in the New Yorker, May 28, 2012, 76-78.

235. These scenes can be viewed on YouTube. One can also view a video uploaded on March 15, 2011 (coincidentally the first day of the civil war in Syria), by Peopleproject depicting scenes of the "Arab Spring" juxtaposed with some soft guitar rock and Chaplin's speech as an off-camera voice here: $<\mathrm{http}: / /$ www.youtube.com/watch?v=ePSqOsMskWQ>.

236. My consciousness of the importance of witnessing and testimony was raised by a 1986 graduate seminar taught by my future thesis director Shoshana Felman. It featured Mallarmé's Musique et les lettres and the films Judgment at Nuremberg (1961) and Claude Lanzmann's Shoah (1985).

237. Christopher Hitchens (1949-2011) made a similar address in his last book, Mortality (2012), which was fittingly reviewed by Christopher Buckley alongside a review of the American edition of Orwell's Diaries that contains an Introduction by Hitchens. See the New York Times Book Review for August 31, 2012.

238. There would be much to say about this paperweight—or perhaps read in the writings of other Orwell commentators who already have said a lot. See Orwell's own thoughts about things in "Why I Write," recently quoted in a review of a re-edition of Orwell's diaries by Simon Leys, "The Intimate Orwell," the New York Review of Books, May 26, 2011: "I am not able, and I do not want, completely to abandon the worldview that I acquired in childhood. 
So long as I remain alive and well I shall continue to feel strongly about prose style, to love the surface of the earth, and to take pleasure in solid objects and scraps of useless information. It is no use trying to suppress that side of myself. The job is to reconcile my ingrained likes and dislikes with the essentially public, non-individual activities that this age forces on all of us." Winston's paperweight, like his conversation with the old man who delights in word-ideas like "pint of wallup," "lackeys," and "top hat" (101-105), could be seen as a form of resistance to "the essentially public, non-individual activities that this age forces on all of us"-and rightly so, because society is not a choice but a necessity. Yet Orwell's and Tocqueville's counterpoint would be that it is also right that individuals should push back and not allow those public activities to have total control.

239. Simon Leys, “The Intimate Orwell," the New York Review of Books, May 26, 2011.

240. Aldous Huxley, Brave New World (New York: Harper Perennial Modern Classics, 2012); Brave New World Revisited (New York: Harper Perennial, 2006). Both works are also available in one volume with a foreword by Christopher Hitchens (New York: Harper Perennial, 2004). Page references will be to the two separate volumes.

241. Hitchens discusses the relations between the two men and their milieu in his foreword, vii-xxi.

242. For another vision from the same era, see Chaplin's film Modern Times (1936).

243. See Jean-Jacques Courtine, “Campus américains: le français en déclin,” Le Monde, November 1, 2010.

244. See The Tempest, V, 1, 205. See, for example, former MLA president Sidonie Smith in her discussion "Narrating Lives and Contemporary Imaginaries" (PMLA 126:3 [May 2011]: 565), "We may feel reduced to a vast yawn or to laments about the insufficient attention to language and literariness or to anxiety about the alliance of selves and marketing in a brave new world of commodities exchanges trading consumption data. This is one way to regard the brave new world of the I. But I want to argue that the narrating I is much more than this reductionist dismissal suggests."

245. BNW, 34. The declaration "History is bunk" is attributed to Henry Ford, the American car maker.

246. For more on the virtues of softness, see Joseph Nye, Soft Power: The Means to Success in World Politics (2004). For more on hardness, see the Wikipedia entries "Bagram Airfield," "Guantanamo Bay Detention Camp," and "Syrian Uprising."

247. A genre inaugurated by Plato's Republic (c. 380 BCE) and in modern times by Thomas More's Utopia (1516). 
248. Of course others, Paul Krugman first among them, are criticizing "austerity" policies as cynical madness.

249. Jean-Michel Heimonet, Les Deux faces du terrorisme et l'autodestruction des sociétés ouvertes (Paris: Kimé, 2005), 76, my translation. The entire chapter this sentence comes from, "Démocratie et Religion," is highly relevant to Huxley's discussion, and in fact Heimonet's book bears many similarities to Brave New World Revisited, most notably the stance of witnessing the tragic self-destruction of open societies.

250. On "the age of isolation" and "the rise of immunity," see Malcolm Gladwell's Afterword to his best-selling magpie study The Tipping Point: How Little Things Can Make a Big Difference (New York: Little Brown, 2002 [2000]), 265-275.

251. On the attraction and repulsion of ruthlessness in American life, see Edward Tenner, "Nasty Like Us," the New York Times, May 26, 2012.

252. The idea of having to choose between two moral visions and two societies has been a recurring theme, especially since 2008, notably in editorials of the liberal economist Paul Krugman and in speeches of the Democratic U.S. president and candidate Barack Obama. This choice was also underscored in a campaign speech in Obama's favor by former president Bill Clinton on September 5, 2012, at the Democratic National Convention: "The most important question is, what kind of country do you want to live in? If you want a you're-on-your-own, winner-take-all society, you should support the Republican ticket. If you want a country of shared prosperity and shared responsibility-a we're-all-in-this-together society-you should vote for Barack Obama and Joe Biden.” Accessed April 15, 2013, <http://www. youtube.com/watch?v=uzDhk3BHi6Q>.

253. For example, Forster's “Bloomsbury” contemporary John Maynard Keynes (1883-1946).

254. For another professor's story of the posthuman, see N. Katherine Hayles, How We Became Post-Human: Virtual Bodies in Cybernetics, Literature, and Informatics (Chicago: University of Chicago Press, 1999).

255. Yet a third volume, Thinking the Twentieth Century, a set of late interviews between Judt and Timothy Snyder, was published in 2012.

256. The expressions are not Forster's, though they could be. They are the watchwords of the educator Kurt Hahn (1886-1974), the inspirational founder of the Outward Bound School: "I regard it as the foremost task of education to ensure the survival of these qualities: an enterprising curiosity, an undefeatable spirit, tenacity in pursuit, readiness for sensible self denial, and above all, compassion.”

257. See Russell A. Berman (2011-2012 president of the Modern Language Association), "From the President: In Defense of Learning, The Seattle 
Convention," MLA Newsletter (Fall 2011). "We are confronting nothing less than a determined counterenlightenment intent on diminishing the cultivation of independent thought."

258. Anger, like ruthlessness, often elicits ambivalent feelings about its productiveness versus destructiveness. For a discussion of one psychologist's thoughts on anger's limited usefulness in couples therapy at least, see Harville Hendrix's bestseller, Getting the Love You Want: A Guide for Couples, 20th anniversary edition (New York: St. Martin's Griffin, 2008 [1988]), xvii-xviii, and other page references under "anger" in the index. The prevailing view is that anger must be "managed." See, for example, Glenn Schiraldi and Melissa Kerr, The Anger Management Sourcebook (New York: McGraw-Hill, 2002).

259. See, for example, the senti/mental education chapters in Part Two of The Memory Chalet.

260. David Brooks, “Milquetoast Radicals," New York Times, October 10, 2011. Brooks concludes his dismissal with one of his customary knowing, adult pronouncements: "Don't be fooled by the clichés of protest movements past. The most radical people today are the ones that look the most boring. It's not about declaring war on some nefarious elite. It's about changing behavior from top to bottom. Let's occupy ourselves." Brooks, a post-boomer born one week after Barack Obama, has made a career as a public intellectual within the Republican party that has become so extreme he passes for a moderate. For more on Brooks's view of radicals, see Part Three, Chapter Two.

261. Kurt Andersen makes a similar claim in "The Downside of Liberty," New York Times, July 3, 2012. However several letters to the editor, "What Do the 60s Tell Us About Today?” (New York Times, July 6, 2012), object against lumping together left-wing social movements and right-wing greed: $<\mathrm{http}: / /$ www.nytimes.com/2012/07/07/opinion/what-do-the-60s-tell-us-abouttoday.html?ref=opinion $>$. Accessed July 7, 2012. See also Charles Taylor's discussion of the gray area between self-fulfillment and self-indulgence in Chapter Five, "The Slide to Subjectivism," of The Ethics of Authenticity, op. cit., 55-69.

262. Nicholas Kristof summarizes these recent events in his largely sympathetic assessment of the Occupy Wall Street movement "The Bankers and the Revolutionaries," New York Times, October 1, 2011.

263. Other dubious zingers include "We no longer have political movements" (134); "We are all democrats today" (144); "Ours is an age of pygmies" (165). These sententious pronouncements weaken Judt's argument and may indeed anger the reader, but in a negative unproductive way.

264. See, for example, James B. Stewart's profile of the French banker Jérôme Kerviel in "The Omen: The Trader Who Brought a Bank to Its Knees," 
New Yorker, October 20, 2008, 54-75. See also John Lanchester's review of 2008 books by David Einhorn, Charles Morris, Kevin Phillips, and Robert Schiller, predicting financial trouble ahead, "Melting into Air: Before the Financial System Went Bust, It Went Postmodern," New Yorker, November $10,2008,80-84$. Judt points the reader to many books, but not to a single one on the housing and financial crisis, though many were published in 2009: Andrew Sorkin's Too Big to Fail (2009), Barry Ritholtz, Bailout Nation (2009), Charles Gasparino, The Sellout (2009), William Cohan, House of Cards (2009), Lawrence McDonald, The Colossal Failure of Common Sense (2009), David Wessel, In Fed We Trust (2009), Justin Fox, The Myth of the Rational Market (2009).

265. Besides the dissident work of Jean-Michel Heimonet and Sheldon Wolin, see the writings of John W. Dean, Broken Government: How Republican Rule Destroyed the Legislative, Executive, and Judicial Branches (2008), Arianna Huffington, Right Is Wrong: How the Lunatic Fringe Hijacked America, Shredded the Constitution, and Made Us All Less Safe (2008), Chalmers Johnson, Nemesis: The Last Days of the American Republic (2008) and Dismantling the Empire: America's Last Best Hope (2011), Christoper Newfield, Unmaking the Public University: The Forty-Year Assault on the Middle Class $(2008,2011)$, Robert Reich, Beyond Outrage (2012), and Naomi Wolf, The End of America: Letter of Warning to a Young Patriot (2007).

266. Even the literal-minded Paul Krugman loses his usual way with words and falls for this misleading metaphor for the title of one of his books, The Great Unraveling: Losing Our Way in the New Century (2003).

267. Lifestyle enclave is a term coined by Robert Bellah and his collaborators in Habits of the Heart to designate pseudo-communities where members "express identity through shared patterns of appearance, consumption, and leisure activities.... They are not interdependent, do not act together politically, and do not share a history" (3rd edition [2008], 335).

268. According to 2009 data, roughly 330,000 business degrees are conferred annually, compared with 130,000 for the next highest major in "social science" that lumps together several disciplines.

269. One can often locate unreferenced passages by using Wikiquote and the "find" function within a digital version of Tocqueville's writings. Judt's epigraph on page 1 comes from DA II, 3, 21, 323-4; Goldhammer 759. The epigraph on page 29 comes from a letter to Ernest de Chabrol dated 9 June 1831. 
In the Internet Age 



\section{Chapter 5}

\section{Democracy Watch 2011}

I wrote the first draft of this chapter-a snapshot of democracy in 2011 - on December 17, 2011, the first anniversary of the day Mohamed Bouazizi, a twenty-six-year-old Tunisian, set himself on fire in front of a government building in the provincial town of Sidi Bouzid in desperate protest against the mistreatment he reportedly suffered from police for illegally selling fruits and vegetables. ${ }^{270}$ Bouazzi would die from his burns eighteen days later on January 4, 2011. His action is credited with sparking the Tunisian "Jasmine Revolution" and more generally the "Arab Spring"-a series of revolutionary uprisings throughout the Middle East that have led to regime change in Tunisia, Egypt, Libya, and Yemen. Other protest movements against authoritarian regimes, notably in Syria, are in progress. Thanks to the Internet, I can "Google" Mr. Bouazizi, read an extensive profile of him on Wikipedia, view footage of the day's commemoration that was broadcast on France's TF1 evening news channel, ${ }^{271}$ or watch an "infographe" posted on the website of France's daily newspaper Le Monde by a photo journalist who visited Sidi Bouzid to do a follow-up story one year after Mr. Bouazizi's immolation. ${ }^{272}$ Or click on any of the hundreds of other links my Google search has generated for me.

On December 25, 2010, Kevin Boyle, an internationally known lawyer, political activist, and "voice for human rights," died of cancer in England at age sixty-seven. Born in Newry, County Down, one of nine children of a Northern Irish Catholic taxi driver, Kevin Boyle studied, practiced, and taught law for thirty years in Galway, Ireland, and later at the University of Essex in England. He was active in the Northern Ireland civil rights movement and went on to defend vulnerable individuals and groups suffering human rights abuses, notably in Turkey, Russia, and South Africa, in trials that contributed significantly to the development 
of international human rights law. He first came to international prominence on July 19, 1989, with the launch of the world statement in defense of Salman Rushdie - a declaration signed by many famous writers and academics who united to oppose the death threats and official fatwa against Rushdie issued by Ayatollah Khomeini earlier that year in the wake of the publication of Rushdie's controversial book The Satanic Verses (1988). ${ }^{273}$ On September 11, 2001, Kevin Boyle began a new job as a close collaborator with the UN High Commissioner for Human Rights, Mary Robinson, the former president of Ireland. He also wrote and edited many books, including Article 19 World Report (1988), Introducing Democracy (1995, with David Beetham, discussed above), and Human Rights and Democracy-The Role of the Supreme Constitutional Court of Egypt (edited with Adel Omar Sherif, 1996). I don't know if Kevin Boyle took note of Mohamed Bouazizi's act of protest during his own last difficult days. His widow, Joan Boyle, told me she wasn't sure. It's a pity in any case that neither man lived long enough to witness the struggle for and against democracy and human rights that ignited in 2011.

On December 5, 2011, parliamentary elections were held in Russia. These elections were marred by allegations of fraud, and these chargessome of which are backed up by video clips uploaded to websites such as Youtube $^{274}$ - triggered protests, notably the large assembly in Moscow on December 10, 2011. ${ }^{275}$ Many observers now wonder if Putin's Russia will also undergo Middle Eastern-style regime change sometime in the near future. ${ }^{276}$ On December 17, 2011, Ellen Barry reported that Russian president Dmitri Medvedev would like to see his and Putin's United Russia Party take the lead in reforming the model of the Russian state, which Medvedev said had "exhausted itself." But it is uncertain how much power or influence Medvedev will have since Putin took over again as president in 2012. ${ }^{277}$

On December 15, 2011, the former French president and former mayor of Paris, Jacques Chirac, was convicted of embezzlement and misuse of public funds to finance his political party by having created fictitious municipal jobs during his tenure as mayor. The court ruled that "Jacques Chirac breached the duty of trust that weighs on public officials charged with caring for public funds or property, in contempt of the general interest of Parisians." 278 He received a two-year suspended 
sentence. The crimes for which he was convicted date back to the early 1990s, but he had exercised his right to immunity, granted by the French Constitution, during his twelve years as president. From 1995 to 2007 he served two terms, first seven years, then five (due to a term-length change in the Constitution). Two days later, his Wikipedia page had already been updated to take into account this first-ever, "historic" conviction of a French president of the Fifth Republic. On December 16, 2011, Le Monde quoted an excerpt from a text read by the former president's lawyer on his behalf in which Jacques Chirac comments on the significance of his trial. ${ }^{279}$

Le principe de responsabilité est au cœur de l'action politique. Je mesure que ce rendez-vous est nécessairement un instant politique. Je crois qu'en permettant de remettre les choses à leur vraie place, [ce procès] peut être bénéfique à notre démocratie. Il donne tort aux démagogues qui soutiennent que, dans notre pays, la justice serait sévère aux faibles et complaisante aux puissants.

If the concept were explained, would Jacques Chirac_or any French person-accept "accountability" as the most proper translation for "responsabilité" in the above quotation instead of "responsibility"? It all depends perhaps on whether one accepts that the French notion of responsabilité contains, besides the standard notion of "to be in charge," the future-oriented notion of "to be held accountable" and therefore "possibly subject to punishment for wrongdoing if the official account of what happened as decided upon in court so demonstrates"- the latter notion being much more clearly and distinctly accounted for by the English term accountability, for which there exists no French equivalent. If he would, then a possible translation of Jacques Chirac's statement could be this:

The principle of accountability is at the heart of political action. I consider this rendezvous [i.e., this trial] as necessarily a political moment. I believe that by allowing things to be put back in their true place, [this trial] can perhaps be of benefit to our democracy. It proves wrong those demagogues who allege that in our country justice is harsh toward the weak and indulgent toward the powerful. 
The journalist comments in a concluding sentence, "These words sounded right [sonnaient juste] in a trial that had become, suddenly, yes, historic." This declaration, including the avoidance of the word trial in favor of the euphemistic rendez-vous, can be seen as a modest effort to conserve a certain grandeur, with a small "g," for the former president who decided in the same spirit of self-denial (i.e., sacrifice of his own selfinterest in favor of the broader interest of the health of France, its judicial system, and democracy in general) to not exercise his right to appeal the court's decision.

The irony that several observers did not fail to underline in the wake of the court's decision was that given the more relaxed mours of ten or twenty years ago in the area of political corruption, ${ }^{280}$ Jacques Chirac might not have been convicted at all had he not exercised his right to immunity back in 1999. Others disagree, pointing to the conviction in 2007 of his associate Alain Juppé (named France's Foreign Affairs minister in 2011) in the same affair. ${ }^{281}$ The Chirac-Juppé affair raises the question of evolving visions of justice and judicial procedure as mours in a particular context change over time. And then there are the complications that arise when mours are significantly different in one context versus another at a given time-something the former director of the International Monetary Fund, Dominique Strauss-Kahn, learned from scandals surrounding his actions in a hotel in New York in May 2011 and other places in France. ${ }^{282}$

Different continent, different news. On December 15, 2011, the New York Times featured this headline in the attention-getting upper-left corner of its website: "U.S. Marks End to 9-Year War, Leaving an Uncertain Iraq." Reporter Tim Arango summed up Thursday's big story in America with this paragraph:

After nearly nine years, about 4,500 American fatalities and $\$ 1$ trillion, America's war in Iraq is about to end. Officials marked the finish on Thursday with a modest ceremony at the airport days before the last troops take the southern highway to Kuwait, going out as they came in, to conclude the United States' most ambitious and bloodiest military campaign since Vietnam. 
Meetings to discuss who was responsible (i.e., in charge) and questions about who, if anyone, will be held accountable for this protracted, costly, and inconclusive war are ongoing, though mostly in the media and on some university campuses, not in the streets or the courts. ${ }^{283}$ To date, for example, no civilian has been convicted of any crime in relation to the torture scandal at the Abu Ghraib prison in Iraq or in relation to allegations of misconduct and illegal actions at other detention facilities since 2001. Detailed and abundantly footnoted accounts of this scandal and of the Iraq War can be found on Wikipedia and in the writings of New Yorker magazine contributors Seymour Hersh and Jane Mayer. ${ }^{284}$

Arango summarized the state of Iraq at the moment of the U.S. pullout with these words:

Iraqis will be left with a country that is not exactly at war, and not exactly at peace. It has improved in many ways since the 2007 troop "surge," but it is still a shattered country marred by violence and political dysfunction, a land defined on sectarian lines whose future, for better or worse, is now in the hands of its people.

The question everyone is asking is whether now, without the authority of Saddam Hussein or the authority of the armed forces of the United States, the different groups that compose Iraqi society are willing and able to live together and share power. "We should finally get some answers about the future for democracy in the Arab world now that U.S. troops have left Iraq," said Middle East specialist Thomas Friedman in his audit-editorial published less than one week after the U.S. pullout on December 20, 2011.285

"A country that is not exactly at war, and not exactly at peace" is also an apt description of Egypt during the weekend of the first anniversary of the Tunisia uprising. On December 17, 2011, the top story in the Middle East for the New York Times was not the first anniversary of Mohamed Bouazizi dousing himself with paint thinner and setting himself on fire, but instead the latest outbreak of violence in Cairo surrounding the controversial parliamentary election process and popular opposition to the military's choice of Kamal Ganzouri as interim prime minister, an illegitimate choice for many Egyptians due to this politician's ties to former 
Egyptian president Hosni Moubarak, who was forced from power on February 11, 2011. ${ }^{286}$ David Kirkpatrick summarizes the grotesque absurdity of the situation in his opening sentence.

Egypt's military rulers escalated a bloody crackdown on street protesters on Saturday, chasing down and beating unarmed civilians, even while the prime minister was denying in a televised news conference that security forces were using any force.

One does not need to be on drugs to view the world with "kaleidoscope eyes" these days; indeed, one could say that arranging as best one can an ever-changing selection of breaking news fragments has become the habit of all those who are trying in good faith to keep up with what appears to be an accelerating, decentralized, interconnected and disconnected, multipolar and yet polarized world. But as with drugs, this type of news gathering can induce dizziness, fever, and fatigue; and it's tempting to respond by either tuning out completely or by delegating the task to one news sifter-the American Family Association, Fox News, MSNBC, the New York Times, Slate, Arts and Letters Daily (a sifter of sifters sponsored by the Chronicle of Higher Education), France 24, Al Jazeera, etc.or to one set of "friends" whose ideology, values, or take on the world one more or less agrees with and let them tell you what you should think about everything. ${ }^{287}$ "It's the attention economy, stupid"-something Tocqueville noticed early on would be of critical importance to relatively weak, insecure, overworked citizens in democratic times.

Of course "friends" written with scare quotes has become a standard way to allude to Facebook's "democratized" social network. ${ }^{288}$ Launched in 2004, Facebook has more members today than any other country in the world except India and China-over 800 million as of December 2011. I mention it because the fictionalized movie version of its founding, The Social Network (2010), was released on DVD on January 11, 2011, just three days before the resignation and departure of Tunisian president Ben Ali, and one month before the resignation of Egyptian president Hosni Mubarak. The DVD grossed over \$13 million in its first week, and the worldwide total gross for the film is roughly $\$ 225$ million. ${ }^{289}$ With Facebook, the sublime of large numbers is everywhere. Facebook, 
along with other social networking sites powered by the Internet, cell phones, and multifunction smart phones, is commonly credited with playing a crucial role in the events of the "Arab Spring." New technologies are also commonly thought to have played an important role in the subsequent "Occupy" movements around the world that sprang up in 2011 in imitation of the occupation of Cairo's Tahrir Square in the winter and spring of 2011, which resumed with more violence in November and December of 2011 as noted above. ${ }^{290}$ Certainly, for now, the violence and stalled reforms of the Arab Spring recall more the crackdown of the 1968 "Prague Spring" than they do the more or less peaceful 1989 "Velvet Revolution" led by Vaclav Havel, who died on December 18, 2011. ${ }^{291}$ Velvet is not the texture that comes to mind when one thinks of the political turmoil that raged across the Middle East between December 2010 and December 2011.

And then there's the Euro crisis. On December 15, 2011, while others may have been thinking about Jacques Chirac, Iraq, or something else, IMF managing director Christine Lagarde, Dominique Strauss-Kahn's replacement as of June 2011 and one of only two women (the other being a high-end prostitute) to appear in the documentary film Inside Job (2010), gave a speech at the U.S. State Department in which she warned that the world faced a 1930s-style economic slump if further international cooperation to solve the crisis did not happen soon. ${ }^{292}$ Lagarde avoided using the D-word, but others such as Paul Krugman have said, "It's time to start calling the current situation what it is: a depression." 293 What's more, some Europeans, many Catholic-influenced Italians, for example, seemed oddly accepting of the harsh austerity medicine that will soon take effect in the form of higher taxes and lower government services and pensions. ${ }^{294}$ Atonement for sins widely shared was the way it has been presented by the post-Berlusconi government of Mario Monti in December 2011, even though many (notably in the "Indignant" and "Occupy" protests) reject this blame-the-public narrative and claim instead that the crisis is a top-down disaster that resulted from wrongheaded policies forcibly imposed by ideologically blinded elites; e.g., the "Bush tax cuts" for the wealthy, the war of choice in Iraq, financial deregulation, and the creation of a common currency, the Euro, without common mores, rules, or principles, such as accountability, to cushion the 
shocks inherent in capitalism and insure member-countries' long-term probity and credit-worthiness. ${ }^{295}$ Viewed from Zuccotti Park or Tahrir Square, it almost looks as though the Euro crisis exists to neutralize the Arab Spring and other grassroots movements in rich or poor countriespushing them off the front pages, out of sight, out of mind-and that if it didn't exist, it would have had to be invented. Is there any truth to that conspiracy theory?

If we have a moral obligation to be intelligent, we have to ask what all these events mean and how they are related, besides being nearly simultaneous. Many have compared 2011 to 1848 , a year Tocqueville knew well, and for that and many other reasons it might be worth looking to the "elegant Norman" for some help. ${ }^{296}$

\section{Notes}

270. For an account of Bouazizi's confrontation with the police, see Kareem Fahim, "Slap to a Man's Pride Set off Tumult in Tunisia," New York Times, January 11, 2011.

271. <http://lci.tf1.fr/monde/sidi-bouzid-des-milliers-de-tunisienscommemorent-le-debut-de-6882262.html>, accessed December 17, 2011.

272. http://www.lemonde.fr, accessed December 17, 2011: <http://www.lemonde. fr/afrique/infographe/2011/12/16/retour-a-sidi-bouzid-un-an-apres-ledebut-du-soulevement-arabe_1619885_3212.html\#ens_id=1245377>.

273. See Kevin Boyle, World Statement: Writers and Readers in Support of Salman Rushdie (London: International Committee for the Defense of Salman Rushdie and His Publishers, 1989).

274. See Andrew Rosenthal's assessment in his December 6, 2011, New York Times editorial "From Russia, with Fraud": http://loyalopposition.blogs.nytimes. com/2011/12/06/from-russia-with-fraud-2/?scp=2\&sq=Russian $\% 20$ election\%20fraud\&st $=$ cse.

275. On the role of the Internet, social media, and the blogger Aleksei Nalvney in the December 2011 protests in Russia, see Ellen Barry, "Rousing Russia with a Phrase," New York Times, December 9, 2011.

276. See the New York Times's "Room for Debate" discussion of whether the Kremlin is losing or loosening its grip (December 12, 2011): <http://www.nytimes.com/roomfordebate/2011/12/12/ is-the-kremlin-loosening-its-grip/?ref=opinion $>$. 
277. Ellen Barry, “Medvedev Urges Reform of Russia’s Political System,” New York Times, December 17, 2011. See also Alena V. Ledeneva, Can Russia Mondernise? Sistema, Power Networks and Informal Governance (Cambridge: Cambridge University Press, 2013).

278. Steven Erlanger, "Chirac Found Guilty in Political Funding Case," New York Times, December 15, 2011. See also the editorial in Le Monde (December 17, 2011): “Un president intouchable, une anomalie": http:// www.lemonde.fr/idees/article/2011/12/16/un-president-intouchable-uneanomalie_1619785_3232.html.

279. Pascale Robert-Diard, "Jacques Chirac condamné, un jugement historique," Le Monde, December 16, 2011. <http://www.lemonde.fr/ societe/article/2011/12/16/jacques-chirac-condamne-un-jugementhistorique_1619692_3224.html>, accessed December 18, 2011.

280. For example, it is public knowledge now, and was insider knowledge at the time that Chirac's predecessor François Mitterrand used taxpayers' money to provide lodgings for a mistress and illegitimate daughter during his presidency. See Raphaëlle Bacqué, Le Dernier Mort de Mitterrand (Paris: Grasset, 2010).

281. See the Wikipedia entry for Alain Juppé. After the election of François Hollande in May 2012, Juppé, who is mayor of Bordeaux, was replaced as minister and declared he would not run for a seat in the National Assembly in June 2012 because he wanted to respect the Socialist government's intention to completely terminate France's tradition of allowing politicians to hold many elected posts simultaneously, the famous cumul des mandats.

282. Again, see the Wikipedia entry “Affaire Dominique Strauss-Kahn.” Le Monde journalist Sylvie Kaufmann published a useful summary in the New York Times, “France, the U.S. and Strauss-Kahn,” July 5, 2011.

283. On low accountability of military leaders, by themselves, civilian leaders, or the public, see Thomas E. Ricks, "Questioning the Brass,” New York Times, November 11, 2012.

284. See, for example, Seymour Hersh, Chain of Command: The Road from 9/11 to Abu Ghraib (New York: HarperCollins, 2004); Jane Mayer, The Dark Side: The Inside Story of How the War on Terror Turned into a War on American Ideals (New York: Doubleday, 2008).

285. Thomas Friedman, “The End, For Now,” New York Times, December 20, 2011. The sentence quoted was the headline subtitle on the website. Accessed December 21, 2011. See also Friedman's global audit in his December 17, 2011, editorial, “Help Wanted.” His main claim is this: "We are present again at one of those great unravelings - just like after World War I, World War II and the cold war. But this time there was no war. All of these states have been pulled down from within-without warning. Why? The main driver, 
I believe, is the merger of globalization and the Information Technology revolution. Both of them achieved a critical mass in the first decade of the 21 st century that has resulted in the democratization-all at once-of so many things that neither weak states nor weak companies can stand up against. We've seen the democratization of information, where everyone is now a publisher; the democratization of war-fighting, where individuals became superempowered (enough so, in the case of Al Qaeda, to take on a superpower); the democratization of innovation, wherein start-ups using free open-source software and 'the cloud' can challenge global companies. And, finally, we've seen (...) 'the democratization of expectations' - the expectation that all individuals should be able to participate in shaping their own career, citizenship and future, and not be constricted." Note here Friedman's recycling of the pesky "unraveling" metaphor (probably a wink at Krugman's book) and his use of the term democratization in the casual way the French often use it to mean "expanded access." Whether this is followed up by true democracy, i.e., expanded access for the Many to real decisionmaking power, remains to be seen. <http://www.nytimes.com/2011/12/18/ opinion/sunday/friedman-help-wanted.html>, accessed September 8, 2012.

286. David D. Kirkpatrick, "Leader Denies Use of Violence as Cairo Crackdown Persists,” New York Times, December 17, 2011.

287. Readers will have noticed my own reliance on the New York Times and the New Yorker magazine.

288. Democratic as opposed to the "aristocratic" Social Register of America's high society.

289. According to Wikipedia, accessed December 18, 2011. On Facebook's alleged tendency to "reduce further the possibilities for improving the real world," see Jean-Jacques Delfour, "Facebook: magasin des amis et désir de police totalitaire,” Le Monde, September 2, 2010.

290. On the role of blogging and social network sites in the "Arab Spring," see David D. Kirkpatrick and David E. Sanger, "A Tunisian-Egyptian Link that Shook Arab History," New York Times, February 13, 2011; and Steve Coll, "The Internet: For Better or for Worse," New York Review of Books, April 28, 2011. Coll's review-essay discusses Tim Wu's The Master Switch: The Rise and Fall of Information Empires (2011) and Evgeny Morozov's The New Delusion: The Dark Side of Internet Freedom (2011). On the Occupy Wall Street movement that began on Twitter on July 13, 2011, and in Zuccotti park on September 17, 2011, see William Yardley, "The Branding of the Occupy Movement," New York Times, November 27, 2011. For a look at OWS through the eyes of one participant, Ray Kachel, see George Packer, "All the Angry People," New Yorker, December 5, 2011, 32-36. On the links between the 2011 Arab winter and spring and the Occupy summer and fall, see Matthew C. Klein, "Educated, Unemployed, and Frustrated, New York Times, March 
20, 2011. Klein does not call for the occupation of Wall Street, but he presciently asks about its possibility in the wake of the protests in Egypt and the "indignant" protests in Western Europe in the spring of 2011. On the shift from blogging to social network sites, see Verne G. Kopytoff, "Blogs Wane as the Young Drift to Sites Like Twitter,” New York Times, February 20, 2011. On the impact of eighty-three-year-old Gene Sharp's heavily downloaded "From Dictatorship to Democracy," see Sheryl Gay Stolberg, "Shy U.S. Intellectual Created Playbook Used in a Revolution,” New York Times, February 16, 2011. Another important geriatric content-provider in 2011 was ninety-four-yearold Stéphane Hessel, whose pamphlet Indignez-vous! (2010; published in English as Time for Outrage!) has sold more than 3.5 million copies worldwide and is credited with energizing popular protests in Spain, France, and elsewhere in 2011.

291. Dan Bilefsky and Jane Perlez, "Vaclav Havel, Dissident Playwright Who Led Czechoslovakia, Dead at 75,” New York Times, December 18, 2011. For a longer profile of Vaclav Havel, see Timothy Garton Ash, “The Revolution of the Magic Lantern,” New York Review of Books, January 18, 1990. Accessed December 19, 2011. Meanwhile, on the other side of the world, the supreme leader of North Korea, Kim Jong-il, died on December 17, 2011.

292. "IMF Warns the World Risks Sliding into a 1930s-Style Slump," Guardian, December 16, 2011.

293. Paul Krugman, “Democracy and Depression,” New York Times, December 11, 2011. The word also appears in the titles of two of his recent books: The Return of Depression Economics and the Crisis of 2008 (2009) and End This Depression Now! (2012).

294. David C. Unger, "Inside the Euro Zone, Bracing for Austerity,” New York Times, December 17, 2011.

295. Paul Krugman, “The Unwisdom of Elites,” New York Times, May $8,2011$.

296. See, for example, Time Magazine World, “1848 vs. 2011,” March 10, 2011. Accessed December 19, 2011. <http://www.time.com/time/magazine/ article/0,9171,2058292,00.html>. A longer more probing article by Robert Freeman, "2011 Is 1848 Redux. But Worse," Common Dreams (www. commondreams.org, March 6, 2011), begins with an epigraph from Tocqueville, a line from a famous speech that Tocqueville gave on January 29, 1848: "Gentlemen, I warn you. Though the violence is not yet upon us, we are sleeping on a volcano." Tocqueville quotes and discusses this speech and other early events in 1848 in the first chapter of his Souvenirs, written in 1850-1851 and published posthumously in 1893. 
Chapter 6

\section{Democracy and the New Dignity}

One way of trying to make sense of the events discussed in the preceding chapter is to interpret them in light of Tocqueville's study of democracy, especially his compare and contrast analysis of the mores of aristocratic and democratic times. So what do those events have to do with Tocqueville and democracy? Directly it would seem not a lot. There have been only scant references to Tocqueville in discussions of the Arab Spring, the Occupy movements, and other "revolutionary" events of 2011. This is a pity, since the escalation of protest in Tunisia, Egypt, and Zuccotti Park receives at least a partial explanation if one remembers the "Tocqueville effect," or "Tocqueville Paradox" as Jon Elster calls it (162-169) — also known as "the theory of rising expectations." Simply stated, it's the idea that one becomes both more desirous for something - e.g., equality, freedom, dignity — as one gets small first doses of it, and less tolerant of doing without it. Although he had sketched this idea in Democracy in America (DA II, 2, 3), the more memorable formulation comes in Book Three, Chapter Four, of The Old Regime and the Revolution (Elster, 164).

It is not always going from bad to worse that leads to revolution. What happens most often is that a people that put up with the most oppressive laws without complaint, as if they did not feel them, rejects those laws violently when the pressure is alleviated. The regime that a revolution destroys is almost always better than the one that immediately preceded it, and experience teaches that the most dangerous time for a bad government is usually when it begins to reform. ${ }^{297}$ 
In 2011 the Internet was abuzz with self-congratulations about the more level playing field (or battlefield) offered by the savvy use of social media sites, laptops, and cell phones that allegedly permitted more efficient organization, mobilization, and execution of protests. Only a few commentators of the Arab Spring made the observation that these protests may have been triggered in part by marginally better living conditions and moderately higher equality that large numbers of both populations had experienced under the Ben Ali and Mubarak regimes. ${ }^{298}$ The relatively more favorable economic conditions and more liberal political situation in comparison with the greater misery within recent memory, combined with the yawning chasm between those still generally paltry living conditions and the opulence of ruling elites in the Arab world, makes the situation rather similar to what Tocqueville describes in the France of Louis XIV to Louis XVI, or, we might add, to Honnecker's German Democratic Republic and the whole Soviet Bloc at the dawn of the Internet age around 1988. But except for the occasional Tocqueville sauce epigraph (most often without a precise reference), his sociological observations have so far not been enlisted to help understand the Arab Spring or Occupy movements, whether to expand or suppress them. ${ }^{299}$ Clearly scholarly voices like Boyle, Elster, Heimonet, and Wolin have not gotten through. If only Gene Sharp had told his many followers to download Tocqueville!

As for "democracy," which has had an image problem going back over two thousand years, not just two hundred, there have been many references to it, but it has taken a backseat to other more pressing concernsjobs and dignity especially. This is partly understandable, especially in the Middle East that has no large-scale economic activities to support a middle class besides the oil industry and tourism. ${ }^{300}$ It should be clear by now that democracy is viewed with ambivalence by many leaders and ordinary citizens - and not just in the Middle East. Republicans-in the U.S., France, and elsewhere-generally favor oligarchy and plutocracy and actively oppose most attempts to introduce more horizontally organized institutions and practices that would welcome and value the presence and input of ordinary people in any decision-making process or collective action. Others, though professing democratic sympathies, often prefer managed, white collar, paternalistic democracy ("Brussels 
knows best") and have hardly any more respect or patience for ordinary contributions than do their Republican counterparts. Both highly credentialed groups generally mock the idea of the "wisdom of crowds" and deride the political involvement of ordinary people as "populism," "mob rule," or "socialism," "fascism," or "communism"-depending on who's listening. ${ }^{301}$

Many people who have never known anything but power pyramids with rigidly hierarchical and static economic and political institutions may be deeply skeptical of democracy as well. Theirs is a radical doubt that doesn't question democracy comparatively-Democracy brand $x$ versus Alternative regime $y$ - on, say, criteria of sustainability, productivity, or other short- and long-term costs and benefits. Instead of arguing, they fundamentally doubt popular sovereignty from the get-go. They no more believe in democracy than they believe in Santa Claus. "Seven billion people governing themselves? Not in a million years!" Others may be honestly undecided about democracy but firmly believe that it's not a priority at the moment, and therefore they push it down lower on their "To Do" list somewhere between "Solve global warming" and "Floss teeth." Or else democracy seems to them like an unreliable, superfluous luxury. ${ }^{302}$ Or too wasteful and slow given the enormity and urgency of present-day global emergencies. ${ }^{303}$ The excuses, always called reasons, are endless. For them, democracy can and must wait. A dream deferred.

All of these views that set democracy aside-whether motivated by cynical power grabs, argued skepticism, paralyzing ambivalence, or total incomprehension and unfamiliarity-are flawed, and yet somewhat understandable in certain circumstances. Again, look at the Middle East. The twenty-three-year-old national motto used throughout the reign of Ben Ali, "Liberté, Ordre, Justice," was replaced not by "Liberté, Égalité, Démocratie" but by “Travail, Liberté, Dignité Nationale" (Work, Liberty, National Dignity). Liberty is retained in the new motto, but it moves to second place, after Work, and functions as the bridge linking Work and National Dignity. The contrast with the former motto of Ben Ali's dictatorship, which had unsurprisingly placed Order in the central position, is stark. But this new motto with its insistence on the concrete primacy of Work before Freedom and Dignity is also strikingly different from the more abstract French revolutionary motto (Liberté, Égalité, Fraternité) and 
from the similarly vague conclusion to the American Pledge of Allegiance with its affirmation of "Liberty and Justice for all." Despite their vagueness, however, the words fraternity and all in these two slogans evoke the sort of social glue that is supposed to unite people in those societies, namely brotherly love and shared freedoms and fairness. Those who put forward the new Tunisian motto- $a$ fundamental exercise in rebranding, let it be said-clearly wanted to go for something more directly graspable. The primacy of assuring one's basic material needs - food, shelter, clothing, health, and education - through "decent work" 304 is understandably uppermost in the minds of millions of poor, unemployed, undernourished, undereducated Tunisians, Egyptians, and "Occupy" protesters throughout the world. Alongside the material benefit of allowing one to secure the basic needs for survival, meaningful work is the cornerstone of the basic spiritual need for dignity, something that Tocqueville and other inheritors of humanist and Enlightenment values came to consider natural to the human species (DA I, 2, 5, 292).

But why "National dignity"? Excess nationalist fervor in the twentieth century in particular has led many to be immediately leery of nationalism and patriotism in all their forms. And Tocqueville had already pointed out that patriotism based on the mere accident of one's birth or upbringing in a particular location- "Proud to be a Mainer"-is strained and phony if it's not undergirded by freely contracted collaborative projects between the state and the citizen in which general public interests (clean air, good roads, quality schools) overlap with particular private ones (my health, my commute, my mind) — the famous "win-win" incentive. Time will tell if there are dark shadows behind Tunisia's choice, but the third element in its new motto may simply be articulating-perhaps imperfectly_another basic spiritual need, which is to belong and to feel a part of the group project of a team, band, party, or cooperative. What's true for signs is true for people as well. No one is totally self-reliant. We don't establish or retain worth (dignity comes from the Latin dignus = worthy) entirely on our own, but through the recognition, the acknowledgment, the respect or love of others, usually close collaborators, whether in running a business, a family, a city, or a nation. ${ }^{305}$ Acquiring, maintaining, building, or restoring dignity, like all value creation, happens in society (including online), and it matters little whether my dignity is inscribed 
within the social context of a city, town, family, tribe, school, church, state, nation, or website. Judt got it right when he essentially repeated Adam Ferguson's affirmation about the primacy of groups (Civil Society, 10) by recalling that "what is truly distinctive about modern life is not the unattached individual. It is society" (Ill, 215). There must be others to ignite the "communal spirit" between citizens who are equal in their "inalienable" human rights, to which lately has been added the right to dignity. ${ }^{306}$ It's understandable, therefore, that Dignité, not Démocratie, was nominated in December 2011 by the French journalist Didier Pourquery as the word of the year.

\section{Q}

The importance of dignity in 2011 had in fact already been declared fundamental back in late January in an eloquent and compassionate editorial by New York Times columnist David Brooks, who rather uncharacteristically channeled his inner Martin Luther King, Jr. or Malcolm X to comment on "the power of the bottom-up quest for dignity" sweeping through the Arab world:

I wonder if sometime around 50 years ago a great mental tide began to sweep across the world. Before the tide, people saw themselves in certain fixed places in the social order. They accepted opinions from trusted authorities.

As the tide swept through, they began to see themselves differently. They felt they should express their own views, and these views deserved respect. They mentally bumped themselves up to first class and had a different set of expectations of how they should be treated. Treatment that had once seemed normal now felt like an insult. They began to march for responsive government and democracy....

Protesters invariably say that their government has insulted their dignity by ignoring their views. They have a certain template of what a "normal" country looks like-with democracy and openness - and they feel humiliated that their nation doesn't measure up. ${ }^{307}$ 
Brooks's main claim is that dignity has gained more dignity in the post-1945 and certainly the post-1989 era, even though it's unclear from his account how "the quest for dignity" could produce "a remarkable democratic wave" given what he calls the "freedom recession" with "more governments retreating from democracy than advancing toward it." Nevertheless, Brooks vividly captures this universal quest for dignity (and maybe for democracy) with the novel image that people "mentally bumped themselves up to first class." 308 There have been a lot of manmade events in the last twenty years that would tend to support what Brooks says, though they are obscured in his retelling behind fanciful images and water metaphors like "wave" and "tide." It is also worth noting Brooks's warning, à la Gene Sharp, that "while the public hunger for dignity is unabated, the road from authoritarianism to democracy is rocky and perilous." The rocky road image is hardly original, but the point being made is hard to disagree with: democracy is definitely not built in a day, a year, or even a decade - nor can it survive without regular exercise and experimentation. The piece also takes a few jabs at the absurdity and fudging of the "tardy" response to the Egyptian revolution by President Obama and his foreign affairs team (which in the Libyan conflict the White House would spin as "leading from behind"), but it recovers its dignity at the end with a concluding recommendation: "If you start with a healthy respect for the quest for dignity, if you see autocracies as fragile and democratic revolts as opportunities, then you'll find it much easier to anticipate events." Tocqueville could not have put it better.

But the similarity between Brooks and Tocqueville does not end there. Nine months later, in an editorial on the Occupy Wall Street movement ("The Milquetoast Radicals," October 10, 2011), Brooks roundly dismisses the demands expressed by some of his fellow Americans for more dignity and fairness and less arrogance and inequality. He shows little sympathy or respect for their quest for dignity, little ability to see the now famous " $1 \%$ " as a powerful but fragile autocracy propped up by willing lawmakers who rewrote the U.S. tax code and pushed through deregulation of the banking industry to allow them to become much richer much faster than anyone else. ${ }^{309}$ Nor does he seem to see the Occupy Wall Street movement as a legitimate revolt designed to combat the attack on dignity that is aggravated by the increasingly extreme inequality 
that has gripped America over the past forty years. ${ }^{310}$ Brooks concludes that piece with an unproven claim and a zinger: "It's not about declaring war on some nefarious elite. It's about changing behavior from top to bottom. Let's occupy ourselves." Such "gotcha!” moments have become common in the Internet age which is also the age of snark. ${ }^{311}$

In the middle of the piece Brooks writes, "If there is a core theme to the Occupy Wall Street movement, it is that the virtuous 99 percent of society is being cheated by the richest and greediest 1 percent." This is a spurious claim. To my knowledge, OWS protestors never claimed that the rich are all "nefarious" and "greedy," only that they could afford to pay more in taxes and that extreme inequality is wrong because unfair, and wrongheaded because economically counterproductive. ${ }^{312}$ Nor do I think the OWS crowd thought of themselves as necessarily virtuous - whatever that means-but that they were decent, hardworking Americans who were getting screwed by an entirely legal but immoral economic, political, and judicial system - a view not very different from Tocqueville's assessment of the way blacks, Indians, and women were being legally mistreated in the 1830s. In any case, this piece and its tart conclusion are more in keeping with Brooks's usual "moderate Republican” stance. The quip "Let's occupy ourselves" is saying "You, Buster, would be better off studying to get into a good college, landing a character-building summer job, getting some marketable skills... And stop complaining!"313 Incidentally, this is also the message that Barack Obama heard as a boy in Indonesia from his mother, Stanley Ann Dunham (Dreams from My Father, Chapter Two).

Of course the classic "bootstrap" argument and "blame the victim" tactics of both American conservatives and France's "meritocracy" apologists on both the Left and the Right are hardly new, but they are less persuasive today when unemployment among college graduates in Europe and North America is higher than ever, the purchasing power of most salaried workers of all ages has stagnated for years, American student debt is through the roof, and median American household assets have fallen by $40 \% .{ }^{314}$ Thus it was child's play for Paul Krugman to nail Brooks, whom he refers to via an anonymous plural "pundits," in a follow-up editorial on November 3, 2011, "Oligarchy, American Style." The irony is that Krugman's conclusion to this piece could have been written 
by Brooks himself so long as he were writing about faraway Egyptians, sheiks, and emirs.

But why does this growing concentration of income and wealth in a few hands matter? Part of the answer is that rising inequality has meant a nation in which most families don't share fully in economic growth. Another part of the answer is that once you realize just how much richer the rich have become, the argument that higher taxes on high incomes should be part of any long-run budget deal becomes a lot more compelling. ${ }^{315}$

The larger answer, however, is that extreme concentration of income is incompatible with real democracy. Can anyone seriously deny that our political system is being warped by the influence of big money and that the warping is getting worse as the wealth of a few grows ever larger?

Some pundits are still trying to dismiss concerns about rising inequality as somehow foolish. But the truth is that the whole nature of our society is at stake.

The point I want to make is that Krugman's correction of Brooks's blindness to the merits of the Occupy Wall Street movement-merits that more and more people can see for themselves without being a Nobel Laureate in economics ${ }^{316}$ —has other historic parallels. It's sometimes said that Tocqueville had an easier time praising democracy when it was happening in far-off America, but when it risked coming in all its unwashed hurly-burly ways to his own backyard in 1848 he was less enthusiastic. Especially if it took the form of socialism, which for Tocqueville was not true democracy, but merely inverted aristocracy. In Tocqueville's eyes, socialism would be a nightmarish Mardi Gras of role reversal between masters and servants extended to all seven days of the week, 365 days a year. For Tocqueville, socialists like Louis Blanqui or Pierre-Joseph Proudon were not community organizing democrats but self-righteous extremists prone to arrogant feelings of superiority and divisive moralizing. The socialist seemed to share the smug certitude of the aristocrat and a similar willingness to take and use other people's money, but in a grotesque, farcical, impromptu way that underscored 
its arbitrariness and questionable legitimacy. Right or wrong about the intentions and motives of socialists (Taking or making? Predators or producers?), Tocqueville's aversion to the specter of socialism and to the revolutionary lyricism of a Lamartine dampened French interest in Tocqueville for over a century. During that time the charge of bad faith and hypocrisy was leveled at the "elegant Norman" for his opposition to Paris workers' demands in the "June days" of 1848 and his acquiescence to an alliance among the various wealthier classes to which he belonged that would allow Louis Napoleon to gain power and squash the quest for work, liberty, and dignity of wage laborers. In June 1848, an estimated 6,500 revolutionaries were killed or executed; another 11,000 were jailed or sent to Algeria. ${ }^{317}$

Reduced to its simplest terms, Tocqueville (or his ghost at least) paid a high price-a century of the silent treatment by most of his countrymen, not just "Marxists"-for seeming to praise democracy in America from his study but impede its advance in France during his ten years as a politician. For the Right (including most of his family members), Tocqueville was faulted for being too sympathetic to the demos; for the Left, he was never sympathetic enough, especially in hard times. Others, though more admiring of him in general, have difficulty reconciling Tocqueville's many insights about regimes that are quite far from his own in space or time (nineteenth-century America, seventeenth- and eighteenth-century France) with what seems to be a lack of feeling and vision in the local circumstances in which he wielded some political influence during the 1840s. However, given the forgetfulness and spontaneous generosity of many people living in later democratic times, David Brooks is unlikely to suffer the same fate; and some may even remember the January "Quest for Dignity" column where the better angels of his nature were singing and pardon his reactionary October column against OWS.

As for Tocqueville, I dare say most Americans paid little attention to his hypocrisy (if that's the right word) in 1848, or in 1893 when the somewhat self-incriminating testimony of the Souvenirs was published, and so they experienced little cause for resentment that would lead them to resist reading Tocqueville. However, as Paul de Man pointed out in the area of literary criticism, a double-stranded rhetoric of "blindness and insight" can weave its way into a variety of contexts, sometimes quite 
unexpectedly. It could be that Tocqueville's limitations as a politician made him realize finally that Democracy in America could not be read as a straightforward how-to manual (a sort of Democracy for Dummies), even though he may have fooled himself for awhile into believing it could. Those lost illusions may have then allowed him to see beyond the limited, static accounts of the Old Regime and the Revolution that his own study of those times - so strikingly sensitive to the unique and evolving conditions constituted by multiple variables-would surpass. The blindness, then, would have been a sort of midwife of the insight.

In the American context, it is generally acknowledged now that a contradiction between generosity abroad and harsh behavior at home has taken place several times in the country's history. Aside from the glaring nineteenth-century example of the practice of slavery in a country that proclaimed all men are created equal, there is the early-twentiethcentury example of wishing "to make the world safe for democracy" during World War I while denying basic rights to American employees who were trapped within the harsh, undemocratic world of the companies for which they worked-in effect autocratic states within the supposedly democratic United States. The grotesque injustice of this contradiction spurred on the Progressive Era and New Deal that resulted in laws that would push back against industry's efforts to flout the more democratic mores that were becoming the new normal outside the factory gates.

More recently, the progressive era known as "the Sixties" took advantage of the Cold War strategy "to contain Soviet aggression" to ask when America's elected officials and judges were going to step in to contain white America's aggression toward African Americans, male American aggression toward women, or straight America's aggression toward the nonstraight. These and other civil rights movements, for greater religious tolerance, for example, included demands for equal dignity and all that goes with it, even if freedom and equality were the dominant watchwords then and not dignity"

More recently still, after 9/11 (and then two wars and a banking disaster, massive recession, double-digit unemployment, worsening statistics on poverty and inequality, and the somewhat disappointing performance of the much vaunted first African American president), Americans seem finally to be getting past "Why do they hate us?" and coming around to 
consider the idea that maybe there is something wrong with what happens on Wall Street - which is of course not an excuse to try and blow it up as was attempted in 1920,1993, and 2001. But this newfound insight, sharpened by attention-getting facts (inequality in America is comparable to what it is in Argentina and worse than in Tunisia and Egypt ${ }^{318}$ ) and slogans ("We are the ninety-nine percent"), has led many to decide that Wall Street does need to be "occupied" by people with values different from the aggressively predatory and unegalitarian culture subscribed to by the majority of the deciders who have worked in New York's financial district for the past forty years. ${ }^{319}$

In December 2010, Mohamed Bouazizi said in effect, "You have robbed me of my freedom, my dignity, my right to work; you have crushed me like a ball of paper. Alright, if I am a ball of paper, then I will light myself on fire." It was a radical strategy for reclaiming his dignity from his own ashes, a gambit that cost him his life but turned him into a national hero and international symbol. There were several copycat immolations in the days and weeks that followed Bouazizi's dignityseeking act of indignation. None of the OWS protestors has gone that far, but they too are trying to reclaim their dignity from the ashes of their dreams that have been incinerated by unemployment, mounting debt, lost savings, lost homes, and what they consider to be mostly deaf media and undignified, derelict politicians and judges. Some are claiming, others just hoping, that 2011 marks the beginning of a new Progressive Era to push back against the abuses and excesses of the past forty years and renew a commitment to protect the universal human right to dignity. ${ }^{320}$

\section{\&}

There are only five references to dignity in the nine hundred pages of Democracy in America. Democracy's emergence out of expanded equality of social conditions is Tocqueville's main topic, not dignity. Nevertheless, these five references are worth noting since the necessity of conserving "the natural dignity of the human species" would seem to be a central concern for him, even if it does not receive lengthy explicit development. Dignity and justice are part of the new grandeur of a democratic regime. These two values compensate for the diminution of old-style grandeur 
that is the inevitable consequence of turning away from the paradigm of the hierarchically organized aristocratic regime.

The reference to dignity cited above comes at the end of a paragraph from $D A$ I, 2, 5, where Tocqueville pauses in his discussion of "public officials under the control of American democracy" to express his indignation at the unfeeling arrogance of French magistrates as compared to the "natural style in the government of democracy," which he prefers.

When I see magistrates in France treating the parties before them rudely or derisively, shrugging their shoulders at the strategy of the defense, or smiling smugly as an indictment is read, I wish that someone would strip off their robes to see whether dressing as ordinary citizens dress might remind these judges of the natural dignity of the human race. ${ }^{321}$

This is the second occurrence of dignité, which comes after a first use of the term in relation to the early Indians whose imperturbable aristocratic-like independence and dignity Tocqueville admires. ${ }^{322} \mathrm{He}$ points out that this is a consequence of a high degree of equality among them, a fact that contrasts with the inequality and hierarchy in civilized countries.

If the common people of civilized countries are coarse, it is not only because they are ignorant and poor but also because, in that condition, they find themselves in daily contact with enlightened and wealthy men.

The daily contrast between their own misfortune and weakness and the prosperity and power of a few of their fellow human beings stirs anger in their hearts at the same time as fear. Their sense of inferiority and dependence vexes and humiliates them. This internal state of the soul is reflected in their mores as well as their language. They are at once insolent and base.

The truth of this is easily proved by observation. The people are coarser in aristocratic countries than anywhere else, and coarser in opulent cities than in the countryside.

Wherever men of such great wealth and power are found, the weak and poor are all but overwhelmed by their baseness. Seeing no way to restore equality, they despair utterly for 
themselves and allow themselves to sink below the threshold of human dignity.

This unfortunate effect of contrasting conditions is not a factor in the life of the savage. The Indians, though all ignorant and poor, are also all equal and free.

When the first Europeans arrived, the natives of North America (...) were governed by a habitual reserve and a kind of aristocratic politeness. (DA I, 1, 1, 81-82, G27)

The key claim in this passage is that loss of dignity, which manifests itself as coarseness (grossièreté), results from unequal conditions and despair at "seeing no way to restore equality." The portrait of the "common people" Tocqueville gives here is complex, comprising both indignant anger toward others and self-doubt about one's own worth-and it rings true with the testimonies one hears from oppressed groups and victims in many contexts where dignity is violated or denied in both material and immaterial ways. ${ }^{323}$

A third reference to dignity occurs in the important tenth chapter of Volume Two, Part One, "Why Americans Devote Themselves More to the Practical Applications of Science than to the Theory." Here Tocqueville conducts one of his masterful compare and contrast analyses of the strengths, weaknesses, and trade-offs of democracy and aristocracy. If in democratic times dignity is more widely felt, "in aristocratic times, vast ideas of the dignity, power, and grandeur of man are widely entertained"-among the aristocrats themselves, it must be stressed, since in their eyes they are the only true men.

In aristocratic societies, the class that shapes opinion and takes the lead in public affairs enjoys a permanent and hereditary place above the multitude and naturally forms a high idea of itself and of man in consequence. (DA II, I, 10, 56-57, G525)

From the perspective of the aristocrat, to be less than the best-less than an aristoi-is to be less than a man. ${ }^{324}$ Nevertheless, if dignity in democratic times is more widely experienced, and the "family of man" therefore a less exclusive club, it is often acquired with difficulty, and its maintenance in a world of change, insecurity, and middling talents and energies is a constant struggle-whereas for the superior-feeling 
aristocrat, it comes with the territory so to speak, and remaining dignified is hardly more difficult than breathing.

The fourth reference to dignity comes in a later chapter on manners where Tocqueville takes pains to show that American manners may not look dignified from an aristocratic perspective, but they have their own sort of homespun, middling dignity that is basically decent despite possible flashes of haughtiness, vulgarity, and unsteadiness due to the democrat's lack of poise and destabilizing self-doubt about his worth and worthiness.

In democratic countries, grand manners are rare because private life is usually quite petty. Manners are often vulgar, because thought seldom has occasion to rise above a preoccupation with domestic interests.

Genuine dignity of manners consists in always appearing to be in one's place, neither higher nor lower. The peasant can manage this as well as the prince. In democracies, everyone's place is in doubt. Hence manners there are often haughty but seldom dignified [in the aristocratic sense]. What is more, they are never well disciplined or instructed. (...)

Still, this is much more evident immediately after the fall of the aristocracy, than it is later on. (...)

In democracies, manners are never as refined as they are among aristocratic peoples, but neither are they ever as crude. You hear neither the swearing of the rabble nor the noble and choice expressions of the high nobility. There is often vulgarity in mores but not brutality or baseness. (DA II, 3, 14, 269, 271, G711, G713)

This is a good example of Tocqueville's core belief that expanding equality of social conditions lowers the high and raises the low and expands the moderate middle. Cast negatively, i.e., from the aristocratic point of view, this evolution lacks dignity in the sense of grandeur, but viewed democratically, it gains dignity in the sense of decency-a key democratic term of praise. The middle might be less grand or even mediocre, but it is not base and thus conserves a decent amount of dignity. 
Tocqueville comes out squarely in favor of this new democratic dignity as decency in the second to last chapter of the whole book, where the best way of defending dignity and independence, he asserts, is by proclaiming oneself to be a friend of equality and actually behaving like one. This recommendation comes at the end of an important paragraph that begins with one of Tocqueville's firmest declarations that looking backward at supreme dignity, grandeur, and absolute power as they existed in aristocratic times is vain and futile. As a reminder to despots still holding on to exclusive power today, as well as to their allies and sympathizers, it is worth citing the whole paragraph and the short ones that frame it.

I believe that it is easier to establish an absolute and despotic government in a nation where conditions are equal than in any other, and I believe that if such a government were established in such a nation, it would not only oppress men in general but in the long run would rob each one of them of several of the principal attributes of humanity.

Despotism therefore seems to me particularly to be feared in democratic ages.

I would have loved liberty in all times, I think, but at the present time I am inclined to worship it.

I am convinced, moreover, that anyone who attempts to base liberty on privilege and aristocracy in the age we are now embarking on will fail. Anyone who attempts to amass and hold authority within a single class will fail. No sovereign today is clever enough or strong enough to establish despotism by restoring permanent distinctions among his subjects. Nor is any lawmaker wise or powerful enough to maintain free institutions if he does not take equality for his first principle and creed. Those of our contemporaries who seek to create or secure the independence and dignity of their fellow men must therefore show themselves to be friends of equality, and the only honest way to show themselves so is to be so: the success of their sacred enterprise depends on it.

Thus the goal is not to reconstruct an aristocratic society but to bring forth liberty from the midst of the democratic society in which God has decreed we must live. 
These two fundamental truths are to my mind simple, clear, and fruitful, and they naturally lead me to consider what kind of free government can be established in a nation in which conditions are equal. (DA II, 4, 7, 389-390, G822)

This passage, which includes the fifth and final reference to dignity, serves to clarify once more several of Tocqueville's key positions. First, it should be noted that he does not advocate a retreat from equality as a way to prevent or reduce the likelihood of despotism. Absolute despotism is more likely under conditions of equality, it's true, but that eventuality should be combated in other ways than by reverting to unegalitarian policies and principles. Second, it is still rather odd that Tocqueville again explains the state of equality as God's decree (or "providential" as he wrote in the Introduction) since throughout the two volumes he has been alluding to specific geohistoric conditions, man-made customs and habits, and policy decisions (e.g., the elimination of entail) that each incrementally expanded the equality of social conditions among Americans and many Europeans and reinforced egalitarian thinking. Moreover, it's presumably because equality can recede-God's decree disobeyed, justice swept aside - that we need to be "friends of equality," i.e., supporting it as sense and sensibility dictate, and presumably combating any return to extreme inequality.

Therefore, because equality of social conditions may be reversed (1830s appearances and a seven-hundred-year-old trend notwithstanding), it is worth befriending and defending equality on the grounds of what a more or less egalitarian society makes possible - the "real advantages" of democracy ( $D A \mathrm{I}, 2,6)$ that are summarized here as "to create or secure the independence and dignity of their fellow men" (and presumably, one day, of women and minorities). In short, independence and dignity, for which equality is a necessary condition, are what Tocqueville is proposing as checks against the establishment of "an absolute and despotic government," which, alas, equality also makes it easier to establish.

But it should also be stressed again that the liberty and dignity that Tocqueville speaks of here are not the same species that would exist in aristocratic regimes. Democratic dignity is more a modicum of decency than high refinement; democratic liberty is more law-abiding entrepreneurship and collaborative experimentation than infinite romantic 
genius, revolutionary individual virtuosity, or unadorned lawlessness. More Ford, less Faust; more Amundsen than Scott, more Emerson than Thoreau, more Whig than wigged out. One may be left free to break the law, but knowing one may be held accountable. ${ }^{325}$ Tocqueville summarizes his defense of the moderate middle two paragraphs later.

Hence there is no reason to expect that the sphere of individual independence will ever be as large in democratic countries as in aristocratic ones. But that is not something to wish for, because in aristocratic nations society is often sacrificed to the individual and the prosperity of the majority to the grandeur of the few. (G823)

In other words, Tocqueville would perfectly understand and perhaps even share in Thoreau's disdain for the achievement of the Egyptian pyramids, which are a monument to the absolute domination of the Few over the Many. ${ }^{326}$ (Walden, Chapter One).

However, as we shall see in the next chapter, Tocqueville also recognized the salutary effects of tolerating and even encouraging the "sphere of individual independence," "freedom of the intellect" (DA II, 1, 2, 19, G493), and the conservation or restoration of all those tendencies that are not native, so to speak, to a particular regime. In the case of a democracy-a predominantly risk-averse regime of savers, not saviors-these would include the promotion of the arts, the public display of fine art, and the study of Latin and Greek and the other non-vocationally oriented disciplines known as the "humanities." But equally important would be the open-ended tolerance in everyday life, enforced by the U.S. Bill of Rights, for example, for indocility, eccentricity, principled civil disobedience, and above all free speech and association. Other "aristocratic" checks on the possible despotism that an egalitarian (and therefore conservative- and conformist-leaning) democratic government might engender include a nosy, indocile free press and free or low-cost institutions: voting, jury duty, libraries, schools, museums, parks, the post office, and today Internet access. Other aristocratic touches he favored, all of which act as "auxiliary precautions" (Federalist \#51) to ward off the bad governance, corruption, and possible tyranny of the majority, include an independent judiciary, a bicameral legislature with longer terms in office 
for one of the two chambers, decent wages and working conditions for government employees, and the veto power of the president. In general, Tocqueville admired the encroachment-preventing apportionment of qualified independence and general dignity among the three branches of the American federal government and between the states and the national government. This can be seen from his sympathetic borrowings from both The Federalist Papers and from the writings of Jefferson that are closer to the "Spirit of '76"-notably his quip about the despotism of a crowd being no less distasteful than the despotism of a single person. ${ }^{327}$

The crucial point of the Tocqueville passage cited above (the opening to the second to last chapter of Democracy in America, where, after nine hundred pages, the author has a last shot to achieve clarity and closure) is that independence and dignity are two of "the principal attributes of humanity." And if humanity is to be defined as all men and women (the demos, and not confined to the grand few, the aristoi), then creating and securing those principles is more likely in times of equality. But it is also at great risk in those same times, and therefore care must be taken to encourage the "manly and legitimate passion for equality" and check the undignified, humiliating, or as he says "depraved taste for equality, which impels the weak to want to bring the strong down to their level, and which reduces men to preferring equality in servitude to inequality in freedom" (DA I, 1, 3, 115, G60). If that could be achieved, then the liberty and dignity of a democratic regime could - at least now and then, fugitively to borrow Wolin's term-be as grand as or greater than that of an aristocratic or republican regime. It's worth repeating that for Tocqueville democracy was not just a form of government; it was a way of life that resulted in a new man. Whether this new man (and woman) is absolutely better is probably undecidable since there would not seem to be any sufficiently external perspective from which to weigh and compare the mores of the inhabitants within different regimes. Therefore, without caving in completely to "cultural relativism" and "anything goes," we can say that the merits and demerits of more or less inclusiveness (or exclusion) within more or less horizontally (or vertically) organized institutions and regimes may be something that well-informed, reasonable individuals and peoples ought to debate and may on various points politely disagree about. 


\section{Notes}

297. See also the Gerald Bevan translation, The Ancien Régime and the Revolution (London: Penguin, 2008), 175. In French, Alexis de Tocqueville, L'Ancien régime et la revolution (Paris: G-F Flammarion, 1988), 266.

298. For an early assessment of the Tunisian revolution, see Robert D. Kaplan, "One Small Revolution,” New York Times, January 22, 2011. See the summary "Zine El-Abdine Ben Ali” in the New York Times, June 20, 2011: “Under Mr. Ben Ali an extensive police state and significant corruption had developed side by side with a relatively large middle class, liberal social norms and broad gender equality."

299. In sociology's modern era, the American James Chowning Davies and his "J-Curve" are more frequently cited than Tocqueville when it comes to explaining revolutions. See the Davies Wikipedia entry and J. C. Davies: “Toward a Theory of Revolution," American Sociological Review 27 (1962): 5-19. See also J. C. Davies, When Men Revolt and Why: A Reader in Political Violence and Revolution (1971).

300. On the slowness of political change in the Arab world due to weak economies, see James Surowiecki, “The Tyrant Tax,” New Yorker, March 7, 2011, 31 : "Government employment is still the easiest route to a job, and subsidies have become more, not less, important... What the region needs is less crony capitalism and more competition. What it might get is political reform accompanied by economic stasis. When it comes to solving economic woes, toppling the tyrants could turn out to be the easy part."

301. Witness, for example, the horrified reaction on October 31, 2011, to Prime Minister Giórgios Papandréou's proposal to organize a national referendum on whether Greece should accept new economic austerity measures-an idea that Europe's economic and political elites quickly encouraged him to let drop.

302. See the opinion of a Chinese youth as reported in Evan Osnos, "Angry Youth,” New Yorker, July 28, 2008, 36: “'Chinese people have begun to think, One part is the good life, another part is democracy, Liu went on. 'If democracy can really give you the good life, that's good. But without democracy, if we can still have the good life why should we choose democracy?'” Other Chinese people consider an open society as essential not, optional. See Eric Abrahamsen, "A Liberal Arts Education Made in China," New York Times, July 3, 2012. But as the American example shows, liberal arts colleges alone do not guarantee democracy and can even hinder it when campus life is too cut off from the real world or focused on other things besides learning.

303. See the opinion of John Elkington, the author of Cannibals with Forks: The Triple Bottom Line of 21st Century Business (1997), as reported by Michael 
Specter in "Big Foot: In Measuring Carbon Emissions It's Easy to Confuse Morality and Science," New Yorker, February 25, 2008: "I believe that much of what we count as democratic politics today will fall apart, because we are simply not going to be able to deal with the scale of change that we are about to face. It will profoundly disable much of the current political class."

304. See the Wikipedia entry "Decent Work."

305. Declaring "I am somebody!" is vain if there's no one around to hear you but rocks, trees, and owls. In the 1970s before the Internet, Jesse Jackson's selfesteem campaign on behalf of African Americans attempted quixotically to build a sense of self-worth amid the indifference or outright opposition of others who were directly or indirectly sending the message, "You are nobody." In the Internet age, everyone is familiar with the emotional, social, and financial payoff of "liking" (i.e., recommending, endorsing) something or someone. This new, more active sense of the verb to like is part of today's new democratic dignity.

306. By lately I do not mean within the past two years. Human rights activists such as Kevin Boyle have long fought for the right to dignity, and the philosopher Charles Taylor, making use of Tocqueville's warnings about the fragility of "political liberty," underlines the threat to "our dignity as citizens" as one of the "three malaises" of our age (the other two being "excess individualism" and the "hegemony of instrumental reason") — and he was writing twenty years before the Arab Spring. See Charles Taylor, The Ethics of Authenticity (Cambridge, MA: Harvard University Press, 1991), 10. Taylor also writes about dignity in Multiculturalism: Examining the Politics of Recognition (Princeton: Princeton University Press, 1994). Other studies of dignity as a human right include The Constitution of Rights: Human Dignity and American Values (1992), Human Rights and Human Dignity (2005), Advocating Dignity: Human Rights Mobilizations in Global Politics (2010), The Politics of Human Rights: The Quest for Dignity (2010), Dignity: In Honor of the Rights of Indigenous Peoples (2010), and Dignity in Adversity: Human Rights in Troubled Times (2011). More recently, see George Kateb, Human Dignity (2011) and Jeremy Waldron's defense of dignity in The Harm in Hate Speech (2012). Waldron's book received a notable endorsement from Stanley Fish in the New York Times, “The Harm in Free Speech,” June 4, 2012, to which Waldron replied, "Hate Speech and Free Speech, Part Two," New York Times, June 18, 2012, and Fish followed up again in "Hate Speech and Stolen Valor," New York Times, July 2, 2012. My point, which this cluster of publications between 1991 and 2011 confirms, is that the new dignity is a significant, large-scale social change among us humans during the post-Cold War, Internet Age. Just as Tocqueville noted the profound changes wrought by the advent of democracy (DA II, 3, 22), the new dignity may have altered the human species. 
307. Emphasis added. David Brooks, “The Quest for Dignity,” New York Times, January 31, 2011, <http://www.nytimes.com/2011/02/01/ opinion/01brooks.html>. Accessed February 28, 2013.

308. A generation ago, this lyrical "we-are-the-world" sentiment was captured in a successful photography exhibit and album entitled The Family of Man (1955). Roland Barthes published a short semiological study of this photo album in his Mythologies (1957). The sentiment has also been expressed by the French philosopher Jean-Luc Nancy, who writes in Vérité de la démocratie (Paris: Galilée, 2008), 61, "la démocratie est aristocratie égalitaire"-democracy is egalitarian aristocracy.

309. And many of "them" are the lawmakers. Forty-seven percent of the U.S. Congress belong to the $1 \%$ according to the Opensecrets.org website of the Center for Responsive Politics as relayed by ABC News: <http://abcnews. go.com/blogs/politics/2011/11/47-of-congress-members-millionaires-astatus-shared-by-only-1-of-americans/>, accessed July 4, 2012.

310. In addition to the writings of Piketty, Saez, and Eduardo Porter, see Timothy Noah, The Great Divergence: America's Growing Inequality Crisis and What We Can Do about It (New York: Bloomsbury Press, 2012). See also Joseph Stiglitz, The Price of Inequality (New York: Norton, 2012).

311. See the writings of Brooks's colleague at the New York Times, Maureen Dowd, who makes Brooks sound like a calm sage. See also David Denby's essay Snark: A Polemic in Seven Fits (New York: Simon and Schuster, 2009). The audio book title is Snark: It's Mean, It's Personal, and It's Ruining Our Conversation (2009). Denby comments specifically on Dowd's destructive snarkiness in this essay.

312. Recent studies argue that extreme inequality is bad for business and a leading cause of the failure of nations. See Daron Acemoglu and James Robinson, Why Nations Fail: The Origins of Power, Prosperity, and Poverty (2012). See also Richard G. Wilkinson, The Spirit Level: Why More Equal Societies Almost Always Do Better (2009) - a new edition appeared in 2010 with an even more affirmative title, The Spirit Level: Why Equality Is Better for Everyone. For a dissenting opinion, see Christopher Snowdon, The Spirit Level Delusion: FactChecking the Left's New Theory of Everything (2010).

313. This was the dominant message of a second Brooks editorial on the same subject published on October 31, 2011, “The Wrong Inequality," which recommends concentrating on "red inequality" (a life expectations gap) and not "blue inequality" (the income gap), with little acknowledgment of the OWS thesis that extreme income inequality is a major cause of the widening gap in life expectations and the disappearance of the middle class. Brooks prefers to side with Charles Murray and see "character flaws" as the cause of America's "coming apart" instead of seeing them as effects of social and economic injustice. The sharply different reactions to Murray's book, Coming 
Apart: The State of White America 1960-2010 (2012), may be taken as a further symptom of the author's basic thesis, namely that America is deeply divided and falling apart.

314. On lost assets, see <http://www.washingtonpost.com/business/economy/ fed-americans-wealth-dropped-40-percent/2012/06/11/gJQAlIsCVV_ story.html>, accessed July 4, 2012.

315. Krugman made his point even more explicit in a follow-up editorial three weeks later, "We are the 99.9\%," New York Times, November 24, 2011. "The recent Congressional Budget Office report on inequality didn't look inside the top 1 percent, but an earlier report, which only went up to 2005, did. According to that report, between 1979 and 2005 the inflation-adjusted, after-tax income of Americans in the middle of the income distribution rose 21 percent. The equivalent number for the richest 0.1 percent rose 400 percent." See also Krugman's earlier piece on OWS, “Losing Their Immunity," New York Times, October 16, 2011.

316. Other New York Times columnists have written sympathetically and eloquently about the OWS movement, notably Nicolas Kristoff, “America's 'Primal Scream': Income Inequality,” New York Times, October 15, 2011. On the problem of Brooks-like denialism, see Charles Blow, "Inconvenient Income Inequality,” New York Times, December 6, 2011. See also George Packer's profile of one OWS participant, Ray Kachel, "All the Angry People," New Yorker, December 5, 2011, 32-38.

317. Tocqueville visited Algeria on two occasions in 1841 and 1846. His writings on Algeria are collected in Tocqueville, Sur l'Algérie, ed. Seloua Luste Boulbina (Paris: GF-Flammarion, 2003). Tocqueville's views on French colonization ought not to be reduced to the labels "hard-liner" or "apologist," but a fuller treatment is beyond the scope of the present study. See Hervé Guineret, Tocqueville, De la guerre au colonialisme: Les enjeux des démocraties modernes (Paris: Ellipses, 2007).

318. See Eduardo Porter's discussion of the measurement of inequality known as the "Gini coefficient” in “The 1 Percent Club's Misguided Protectors," New York Times, December 10, 2011. See also <http://www.globalresearch.ca/ index.php?context=va\&aid=22999>, accessed July 4, 2012.

319. The literature on modern predatory culture stretches from Thorstein Veblen's Theory of the Leisure Class to Robert H. Frank and Philip J. Cook's The WinnerTake-All Society: Why the Few at the Top Get So Much More than the Rest of Us (New York: Penguin, 1996). On predatory culture in politics, see Paul Pierson and Jacob Hacker, Winner-Take-All Politics: How Washington Made the Rich Richer, and Turned Its Back on the Middle Class (New York: Simon and Schuster, 2010). 
320. See Jeffrey D. Sachs, “The New Progressive Movement,” New York Times, November 12, 2011. There are wider questions of animal, plant, and planet rights, perhaps including dignity, that extend beyond the scope of the present study. See Dominique Bourg and Kerry Whiteside, Vers une démocratie écologoque (Paris: Seuil, 2010).

321. This is the Goldhammer translation, page 233, except I have substituted Bevan's word smugly for indulgently to render the French sourire avec complaisance. What Tocqueville dislikes is the callous feeling of superiority of these French judges, and that seems to be communicated better with smugly. See DA I, 2, 5, 292: "Quand je vois, parmi nous, certains magistrats brusquer les parties ou leur adresser des bons mots, lever les épaules aux moyens de la défense et sourire avec complaisance à l'énumération des charges, je voudrais qu'on essayât de leur ôter leur robe, afin de découvrir si, se trouvant vêtus comme les simples citoyens, cela ne les rappellerait pas à la dignité naturelle de l'espèce humaine."

322. In his Essay on the History of Civil Society (1767), Adam Ferguson expressed similar praise of the inhabitants of "rude nations" based on what he had read of Indians in travel narratives.

323. One thinks of the treatment of "aliens" by immigration officials or the experience of prisoners such as the account by James Baldwin in his autobiographical essay "Equal in Paris" reprinted in Americans in Paris, ed. Adam Gopnik (New York: Library of America, 2004), 467-481.

324. See Part One, "L'Invention des semblables," in Pierre Rosanvallon's La Société des égaux (Paris: Seuil, 2011), 25-106. See also Primo Levi, Se questo è un uomo / If This Is A Man (1947, 1958).

325. On the necessity of restraints as a component part of freedom, see Adam Ferguson, Essay, op. cit., 150-151: "Where the citizen is supposed to have rights of property and of station, and is protected in the exercise of them, he is said to be free; and the very restraints by which he is hindered from the commission of crimes, are a part of his liberty. No person is free, where any person is suffered to do wrong with impunity. Even the despotic prince on his throne, is not an exception to this general rule. He himself is a slave, the moment he pretends that force should decide any contest. The disregard he throws on the rights of his people recoils on himself; and in the general uncertainty of all conditions, there is no tenure more precarious than his own."

326. On "vulgar" and "sensible" grandeur, see Henry D. Thoreau, Walden, Chapter One, "Economy”: "The grandeur of Thebes was a vulgar grandeur. More sensible is a rod of stone wall that bounds an honest man's field than a hundred-gated Thebes that has wandered farther from the true end of life. The religion and civilization which are barbaric and heathenish build splendid temples; but what you might call Christianity does not. Most of 
the stone a nation hammers goes toward its tomb only. It buries itself alive. As for the Pyramids, there is nothing to wonder at in them so much as the fact that so many men could be found degraded enough to spend their lives constructing a tomb for some ambitious booby, whom it would have been wiser and manlier to have drowned in the Nile, and then given his body to the dogs."

327. In Federalist \#48, Madison quotes from Jefferson's Notes on the State of Virginia about the danger of too much power concentrated in the legislative branch: "[C]oncentrating these in the same hands, is precisely the definition of despotic government. It will be no alleviation, that these powers will be exercised by a plurality of hands, and not by a single one. One hundred and seventy-three despots would surely be as oppressive as one. Let those who doubt it, turn their eyes on the republic of Venice. As little will it avail us, that they are chosen by ourselves. An ELECTIVE DESPOTISM was not the government we fought for; but one which should not only be founded on free principles, but in which the powers of government should be so divided and balanced among several bodies of magistracy, as that no one could transcend their legal limits, without being effectually checked and restrained by the others." See DA I, 2, 7, 360, G300. 


\section{Chapter 7}

\section{What Would Tocqueville Do?}

\section{Some Policy Recommendations for Democrats and Dictators}

But can we be sure that the new dignity is a sign of democracy's triumph in the post-Cold War Internet age? What if this new dignity were not a sign of democracy's victory but of its defeat? It should be remembered, for example, that many people view the affirmative action and multiculturalism drives of the 1970s and '80s not as new social strengths that have their origins in the liberation movements of the sixties, but as admissions of failure (to integrate and involve others around defining and advancing common goals) - failures that display themselves in the tactical maneuvering of "identity politics," special pleading for "diversity," quotas, and the like. ${ }^{328} \mathrm{~A}$ similar discrepancy between appearances and realities, theory and practical outcomes, is noted by the critics of organized labor who attack the successes of labor unions by pointing to cases of abuse or by making unproven blanket statements such as unions are bad for business, make the labor market too rigid, tie the hands of management, etc.-oddly forgetting that pushing back against the overly free hand of management was the whole purpose of unions to begin with, just as affirmative action and multiculturalism were generally considered to be necessary steps to break the undemocratic white male lock on economic opportunity and political power that existed in twentieth-century America until the 1970s, even if each in time generated its own set of problems (e.g., reverse discrimination and sectarianism).

So what about dignity? Might all the high-minded dignity talk of the last twenty years actually be a symptom of today's phony, cynical democracy-lite as described by Wolin? In other words, is dignity talk a bone 
thrown to the Many in consolation for the hijacking of public debate and political rights by the Few, and for the big merger between today's politicians and wealthy corporations that took place largely without people's consent or knowledge? Is it a sideshow to conceal democracy's decline? Is dignity talk another case of charity substituting for justice? Or is it justice trying to emerge as best it can in the face of widespread opposition? Just as Jesse Jackson's poignant "I am somebody" dignity campaign in the early 1970s expressed more a future wish for a "rainbow coalition" than a present reality, ${ }^{329}$ it's worth noting that forty years later some people view the "first African American president" as a good house nigger with whom they can do business, but a nigger all the same. ${ }^{330}$ More generally, there is certainly ample evidence in the daily news (hazing, sexual assault, domestic violence, illegal and immoral predatory behavior of all kinds, escalating unemployment, poverty, homelessness, and hopelessness) that would suggest the new dignity and the human rights agenda articulated in the Universal Declaration of Human Rights in 1948 remains a dream that has not yet been fulfilled. ${ }^{331} \mathrm{~A}$ beautiful dream, perhaps, but not the daily reality of most people, who, on the contrary, are stuck in a "freedom recession."

If democracy is the form of government best equipped to fulfill the promises contained in the Universal Declaration of Human Rights - the most translated document in the world according to the Guinness Book of Records - there remains the challenge of how to "install" that operating system in places where it has hardly ever existed, and the even greater challenge of how to defend it in places where it is under direct attack and shore it up in places where it is suffering daily indirect attacks on its advisability, affordability, or sustainability in today's world. ${ }^{332}$ Tocqueville can be of help in this struggle for democracy and dignity. And of course his words can also be of use to dictators and democracy skeptics who need only to read his recommendations and design ways to undermine their implementation - the most effective strategy being simply to do nothing, since as Tocqueville has demonstrated, left to its own designs without "auxiliary precautions," democracy quickly runs itself into the ground all on its own without the intervention of outside "evildoers."

American democracy circa 1830 took two generations to build. It followed several generations of local, in-house trial and error experiments 
in community organizing that had been going on since 1607. A shaky version 1.0 came online slowly between 1776 and 1781, and then a version 2.0 went public in 1788 with a succession of patches and add-ons over the next fifty years. But on its present destructive course, American democracy's death will likely coincide with the extinction of the last baby boomers sometime around 2040, i.e., the bicentenary year of Volume Two of Democracy in America.

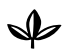

Those who would like to avoid the irony of having some lines from Tocqueville read out at democracy's funeral will want to pay attention to his list of recommended attitudes and policies put forward with near bullet-point clarity in the second to last chapter of Democracy in America (DA II, 4, 7, 389-397). His list of the behaviors he wants to encourage and those he wants to discourage is predicated on the idea that it would be best to avoid "an absolute and despotic government" and embrace the "saintly enterprise" of creating and securing ordinary "independence and dignity" by being friends of equality. In other words, Tocqueville's list is written for those who want to defend and strengthen democracy, not kill it off or keep it from emerging in the first place. He has made up his mind that political equality ought not to be denied in times that have seen the expansion of equality in all other areas. This follows from his early claim (DA I, 1, 3) that it's impossible to keep men unequal in one area while they're equal in all others: "On ne saurait concevoir les hommes éternellement inégaux entre eux sur un seul point, égaux sur les autres" (DA I, $115, \mathrm{G} 60$ ). This may sound like trying to get an "is" from an "ought," yet he acknowledges the possibility that some may want to have nearly all men (besides themselves, of course) be equally powerless when it comes to politics (i.e., public debate and decision making) instead of similarly empowered.

Tocqueville is perfectly willing to concede that some prefer vertical, hierarchical social arrangements of authority (in some, many, or even all settings) over inclusive, horizontal, i.e., democratic decision making. And so do most people. After all, who thinks an airplane pilot should walk back to the passengers in coach and ask them how to respond to the turbulence that the plane is experiencing? How many people think children 
under twelve should be invited to debate their bedtime? Or be co-equals in primary school curriculum planning? In many areas most of us expect hierarchies of competence and power and find an "elitist" selection based on tests, relevant experience, or other objective criteria to be just and good. However, there are many areas where reasonable people may differ about who gets to participate in the decision-making process, how, and how much. This is why Tocqueville concludes his "Real Advantages of Democracy" chapter (DA I, 2, 6) with the direct, second-person address to his readers to get clear about what they really want. The passage is worth citing in full.

What do you want from society and government? Clarity on this point is essential.

Do you wish to impart a certain loftiness to the human mind, a generous way of looking at the things of this world? Do you want to inspire in men a kind of contempt for material goods? Do you hope to foster or develop profound convictions and lay the groundwork for deep devotion?

Is your goal to refine mores, elevate manners, and promote brilliance in the arts? Do you want poetry, renown, and glory?

Do you seek to organize a people so as to act powerfully on all other peoples? Would you have them embark on enterprises so great that, no matter what comes of their efforts, they will leave a deep imprint on history?

If, in your view, these are the main objectives that men in society ought to set for themselves, do not choose democratic government, for it offers no guarantee that you will reach your goal.

But if it seems useful to you to turn man's intellectual and moral efforts to the necessities of material life and use them to improve his well-being; if reason strikes you as more profitable to man than genius; if your purpose is to create not heroic virtues but tranquil habits; if you would rather see vice than crime and are prepared to accept fewer great deeds in exchange for fewer atrocities; if, instead of a brilliant society as a stage for your actions, you are willing to settle for a prosperous one; and if, finally, the principal purpose of a government 
is not, in your view, to make the nation as a whole as glorious or powerful as can be but to achieve for each individual the greatest possible well-being while avoiding misery as much as possible; then equalize conditions and constitute a democratic government.

But if the time for choice is past and a force superior to man is already, without consulting your wishes, propelling you toward one of these two forms of government, try at least to get out of it all the good that it can do; and knowing its good instincts as well as its wicked inclinations, strive to limit the effect of the latter and promote the former. (DA I, 2, 6, 341342, G281-282)

Many readers will probably focus their attention on the contrasting portraits of the aristocratic regime (presented via questions) and the democratic regime (presented as a series of "if" clauses), perhaps wondering to what extent the two roads pointed out to "you" are mutually exclusive. However, the last paragraph is also important since it contains Tocqueville's advice about what to do in the likely event that one is not entirely free to choose the regime one will live under. In that case, says Tocqueville, whether it be horizontal democracy or vertical authoritarianism, or some combination of both, try and make the most of it by staying alert to your regime's positive and negative tendencies and doing your best to restrain the latter while encouraging the positive aspects. Mindful perhaps of this pragmatic advice from $D A$ I, namely the necessity of paying constant attention to the positive and negative dispositions and inclinations given the conditions at a given moment, he then proceeds in the second to last chapter of DA II to make his list of policy recommendations that will favor "manly" liberal democracy and discourage the oppressive "soft" democratic-despotism he described in the previous chapter ("What Kind of Despotism Democratic Nations Have to Fear," DA II, 4, 6).

His first observation is that it makes no sense to come out in favor of "small government" and try to shut down or dismantle the state (Paul A. Rahe and Teapartiers take note). For Tocqueville, remember, soft despotism is preferable to a free-for-all and also better than traditional, hard totalitarianism. It's necessary and desirable that the state should be active 
and powerful in democratic times since individuals are all relatively weak, but it should be kept from abusing its agility and force ("Il ne s'agit point de le rendre faible ou indolent, mais seulement de l'empêcher d'abuser de son agilité et de sa force." DA II, 390, G823).

The second observation is similar to what Publius asserts in Federalist \#51, namely that "In framing a government which is to be administered by men over men, the great difficulty lies in this: you must first enable the government to control the governed; and in the next place oblige it to control itself." The levers for obliging the central government to control itself in aristocratic times were the regional power centers of quasi-independent dukes, counts, princes, and other local lords who could extend or withdraw their cooperation when it came to the royal administration of government policies (i.e., their interpretation, application, and enforcement). (See Shakespeare's history plays, e.g., Richard II and Richard III, for proof of this.) In democratic times those independent instruments of control are by definition lacking, but substitute "democratic procedures" can replace them, says Tocqueville, and these will serve the same purpose of preventing the central power from both governing and administering, lawmaking and law enforcing over every nook and cranny of citizens' lives. ${ }^{333}$ Tocqueville shares the Federalist view that the "partition of power," keeping it divided and dispersed-the famous "branches" of government_-reduces the likelihood of tyranny, but dismantling the state increases the likelihood of having society swing endlessly and unpredictably between extremes of anarchy and tyranny.

I am well aware that today these [aristocratic] methods will not do, but I see democratic procedures replacing them.

Rather than transfer all administrative powers from corporations and nobles to the sovereign alone, some of those powers can be entrusted to secondary bodies temporarily constituted of ordinary citizens. In this way, the liberty of private individuals can be made more secure without diminishing their equality. (DA II, 390, G823)

Over the next seven pages Tocqueville praises once more the freely engaged in associative life in democratic regimes as that which will check and counterbalance the central power's tendency to want to make and 
enforce all the rules. If hereditary civil servants are out, they can nevertheless be replaced in democratic times by elective ones or by individuals appointed by elected officials to serve on local agencies, boards, commissions, and other administrative bodies. These democratic assemblies, says Tocqueville, perhaps inspired again by arguments from The Federalist, have the benefit of creating quasi-aristocratic offices without aristocrats. ${ }^{334}$ There is the status honor, even holiness ("sainte entreprise"), attached to carrying out a certain task judged valuable by the group. And since the tasks are carried out by the power vested in one's office, not "in me," the impersonal execution qua president, senator, sheriff, chair, dean, or school superintendent brings less risk of the traditional aristocracy's injustices and dangers, namely arbitrariness, arrogance, blindness, cronyism, encroachment, favoritism, impulsiveness, impunity, immunity, insularity, lawlessness, overreaching, secrecy, smugness, or all of the above. Play the role of aristocrats, for a term or two, "temporarily," but not be aristocrats - that's the thing.

I am firmly convinced that aristocracy cannot be reestablished in the world. But ordinary citizens, by associating, can constitute very opulent, very influential, and very powerful entities - in a word, they can play the role of aristocrats.

In this way one could obtain several of the most important political advantages of aristocracy without its injustices or dangers. A political, industrial, commercial, or even scientific or literary association is an enlightened and powerful citizen that cannot be made to bow down at will or subjected to oppression in the shadows, and by defending its rights against the exigencies of power it saves common liberties. ( $D A$ II, 391, G823)

Note the list of the different kinds of associations and therefore possible roles: "political, industrial, commercial, or even scientific or literary association." Tocqueville is clearly suggesting that many other groups besides just the legal community (praised in DA I as a check on the omnipotence of the majority) can also play a counterbalancing role in democratic times. Among these are political groups (parties, lobbies, interest groups), private businesses, and as an afterthought perhaps but 
nevertheless included in the list are academies in the arts and sciences. Tocqueville could have little inkling about the future development of liberal arts colleges and research universities in the second half of the nineteenth century, but these associations qualify in his mind as positive counterweights to democratic tyranny, similar to the role played by the legal community and religious organizations.

Higher education is inescapably hierarchical and therefore aristocratic with its groupings and rankings of various knowledge workers and apprentices. (Those who know about a given subject get to stand at the head of the class before those who don't.) And yet it is oftentimes democratic when it comes to its internal organization with faculty senates, peer review, and professor-presidents. For a century after Tocqueville's death, higher education's federating institutions (the Modern Language Association, American Historical Association, etc.) expanded and gained influence as important "auxiliary precautions" (Federalist \#51) against the omnipotence of the majority. Like the legal profession with its "bar association," academics in all disciplines value literacy, memory, logic, attention to detail and particular cases, and the cautious formulation and application of general principles, theories, and laws within reasoned arguments. As such, these "communities of memory" (Bellah) where academics do their work (sifting the past, examining the present, and setting a course for the future) strengthened democracy's ability to criticize itself - a role that was left to lawyers, judges, preachers, and journalists in Tocqueville's day, with imperfect results as he observes when lamenting the high degree of conformism and low liberty of intelligence in America (DA I, 332). Scientific and literary associations that sprang up around the country between 1860 and 1960 — whether broad-based public universities or smaller but broad-minded private liberal arts colleges - fulfilled Tocqueville's wish for "enlightened citizens" to act as defenders of "common liberties." John Dewey (1859-1952), who was born the year Tocqueville died, was instrumental in articulating a new democratic relationship between schools and society that became a successful nationwide model (see his Democracy and Education, 1916). ${ }^{335}$ Today, however, "the higher learning in America" (Veblen), like the country's brand of democracy, is in deep crisis even as foreign students continue to flock to American campuses and foreign academics seek to 
imitate some American academic ways at their home institutions. ${ }^{336}$ Yet one more ironic legacy.

Other things that Tocqueville says ought to be stressed in democratic times, precisely because of the demolander's self-destructive tendency to ignore or reject them, include the following three related items.

Teach democratic man the value of forms (G826). In aristocratic times when the classical doctrine based on clarity, order, and rules was preeminent, there was no need to insist on the importance of manners, grammar, rituals, and ceremonies. In democratic societies where even spelling rules or stop signs can seem like an imposition, it is necessary to counteract the democrat's tendency to consider all forms as annoying restraints and infringements on personal freedom. Not to do so is to weaken respect for the rule of law, which is a cornerstone of any democracy.

Teach respect for individual rights (G824-827). In democratic times that develop a passion for equality, tranquility, and blind obedience to majority rule (often in the name of "team spirit" or "family values"), it is easy for demolanders to have a bully's contempt for individual rights, especially the right to think and act differently from the group. ${ }^{337}$ Therefore it is of special importance that a free press and an independent judiciary be able to continuously remind forgetful, busy, outwardly brash but secretly insecure demoland citizens of (1) the importance of individual rights (freedoms to and freedoms from), not least because ideas and initiatives are almost always in someone's head before becoming a collective idea, value, or project; (2) the general superiority of reality-based decision making over faith-based or fantasy-based decision making; and (3) the utility of the universal insurance policy provided by formal legal principles such as habeas corpus and due process that can be exercised on a moment's notice even by individuals who, like in the case of catastrophic illness, think "that is never going to happen to me." Alongside respect for individual rights and forms, a free press and independent judiciary are two more indispensable cornerstones of a democracy that it is in everyone's interest - for their own good and the good of societyto cherish and uphold by demonstrating as often as necessary that the group (team, town, nation) is safer and stronger with them than without them. ${ }^{338}$ 
Temper the taste for movement, speed, and revolution (G827). For example, nothing is more normal in democratic times than a passion for "fast food." It dovetails perfectly with the democrat's desire for all that is quick, cheap, and "good enough." But a "fast food nation" could learn a thing or two from the "slow food" movement that started in "Old Europe." 339 Movement, speed, and change, which have often been practical necessities at many times in human history, should not be allowed to be promoted as ends in themselves - and particular suspicion should be applied to instances where, in Orwellian fashion, permanent change is promoted by so-called conservatives ("War is peace"). Tocqueville notes how the demolander's "taste for change" is related to his contempt for forms and the seductiveness of force.

When any nation changes leaders, opinions, and laws several times within a short period, the men who compose it end up acquiring a taste for change and becoming accustomed to the idea that all change occurs rapidly with the help of force. They then naturally conceive a contempt for forms, whose lack of power they witness daily, and they become impatient with the dominion of rules, which they have so often seen flouted before their very eyes. (DA II, 394, G827)

Tocqueville no doubt had France's protracted nineteenth-century revolutionary history in mind, but there are hundreds of more recent examples of "revolutionary changes" and not just in the world of hightech. For example, it is interesting to learn that PepsiCo, the global snack food giant, is in the process of rethinking its 1960s-inspired brand of endless, impulsive "fun and freedom" products (e.g., chips and soda) and will perhaps try to reposition itself as a health-food giant. Or that Pixar thinks of itself as a virtuous "fun factory," a new-and-improved Disney that "really should be running Western Civilization." ${ }^{340}$ But experience has shown that the virtue of multinational corporations, like the virtue of nations, though to be welcomed, is often expensive, unreliable, and shortlived due to the frequent conflicts that crop up between doing good and doing well (enough). And when that happens, some auxiliary force must be exerted to advocate and enforce policies that will supply "by opposite and rival interests, the defect of better motives." ${ }^{341}$ This auxiliary 
force, which some will invariably decry and oppose (usually because it restrains their force), can emanate from any of the three branches of government-or from another source such as the press (including literature and now the "blogosphere" and "twitterverse"), NGOs, the academy, the marketplace, the pulpit, or from groups or individuals whose power is boosted by the Internet.

In an evocation of the problematic relationship of "Capital and Democracy" that occurs late in the expanded edition of Politics and Vision, Sheldon Wolin summarizes well the human costs of unimpeded glorification of high-speed, permanent change.

[W] ho is to define and control the course of change, and who is to bear the brunt of it? The fact that scientific and technological advances have made available the power of introducing continuous, unrelenting change as the organizing focus and distinctive mark of postmodern societies can also be seen as the principle by which elites establish their credentials to monopolize policy determinations and promote the culture that validates themselves. As several commentators have noted, the powers embodied in modern change do not enter the world without disrupting and eventually destroying established life-forms of work, play, personal and social relations, belief, and habitat. Those who define, direct, finance, and prosper from significant change rarely experience their own lives mangled or stupefied and the misshapen results passed on as an inheritance. (597)

Tony Judt might have cited those words in his case study of Britain's mangled rail and bus service; admirers of Charles Murray's research might want to factor in Wolin's observations when trying to understand what's "coming apart" today and who or what is to be held accountable; and Paul Krugman might consider "The Great Mangling” or "Mangled and Stupefied" as a catchy title for his next chronicle of world economic history.

Turning back to Tocqueville, his observations about contemporary trends in this penultimate chapter concludes with a short list of goals 
(each introduced by an infinitive verb) that are most proper in "a world that is totally new" (G7).

The political world changes. We must now seek new remedies for new ills.

To set broad but visible and immovable limits on social power; to grant certain rights to private individuals and guarantee their uncontested enjoyment of those rights; to preserve what little independence, strength, and originality is left to the individual; to raise him up alongside and support him vis-à-vis society; these seem to me the primary goals of lawmakers in the age upon which we are just now embarking. (DA II, 396, G829, emphasis added)

It is important to note again that these are context-specific recommendations, not absolutes. Just as a cancer patient doesn't receive the same treatment as a diabetic, other social ills would require other remedies. The situation as Tocqueville sees it in 1840 requires the measures he lists for the reasons he has already stated at length. And for one more that he repeats in the paragraphs that follow the one just cited: namely, the fact that in democratic times there are large numbers of people who "abandon liberty because they deem it to be dangerous" while others, "fewer in number but more enlightened," also abandon liberty "because they judge it to be impossible" (G830). Tocqueville is particularly sharp with the latter on this page, probably because many come from within his own peer group from which he takes his distance.

Among our contemporaries I see two ideas which, though contradictory, are equally disastrous.

Some see in equality only the anarchic tendencies to which it gives rise. They are terrified of their free will; they are afraid of themselves.

Others, fewer in number but more enlightened, take a different view. Alongside the road that leads from equality to anarchy, they have at last discovered the path that seems to lead men ineluctably into servitude. They adapt their souls in advance to this inescapable servitude and in despair of 
remaining free already worship from the bottom of their hearts the master who is waiting in the wings.

The former abandon liberty because they deem it to be dangerous, the latter because they judge it to be impossible. (G829-830)

However, Tocqueville does not despair but instead tells the reader once more the reason behind his whole enterprise - the raison d'être of the whole book- which is grounded in his belief that liberty is not necessarily dangerous nor is it impossible.

If I held the latter belief [i.e., that liberty is impossible], I would not have written this book. I would have confined myself to bewailing the fate of my fellow men in private.

I chose to speak out publicly about the dangers that equality poses to human independence because I firmly believe that those perils are the most formidable that the future holds, as well as the least anticipated. But I do not believe that they are insurmountable. (G830)

In other words, Tocqueville does not believe, as many did and still do, that democracy is doomed to fail. He goes on to conclude this penultimate chapter with a final recommendation to his readers to maintain a "salutary fear" that will keep one "vigilant and ready for battle" and help fend off "the spineless and idle terror that afflicts and saps the heart"the latter being a self-destructive, unsalutary yoke.

Vigilant and ready for battle strikes me as a stance worth adopting today if we are to pursue the worthy task that Sheldon Wolin, one of Tocqueville's most astute readers, recommends to us in times of Superpower: "to nurture the civic conscience of society" (Politics and Vision, 606). But are there enough of $u$ interested in that nontrivial pursuit today who are motivated and strong enough to oppose those of $u s$ who have other interests and motives? We shall see. 


\section{Notes}

328. See Arthur M. Schlesinger, Jr., The Disuniting of America: Reflections on a Multicultural Society (1991).

329. Jackson's consciousness-raising political career was one of the early manifestations of the multicultural movement that grew out of the sixties black power movement. A YouTube video of a 1970s Sesame Street episode shows him rallying a colorfully dressed, ethnically diverse set of little kids around his catechism: <http://www.youtube.com/watch?v=iTB1h18bHlY>.

330. Google "Obama house nigger" to see the number and variety of people who have made this charge.

331. The Wikipedia entry "Universal Declaration of Human Rights” contains background information and the full text. Dignity is mentioned in the first line of the preamble and in the first sentence of article 1: "Whereas recognition of the inherent dignity and of the equal and inalienable rights of all members of the human family is the foundation of freedom, justice and peace in the world...." Article 1: "All human beings are born free and equal in dignity and rights." Dignity also occurs in articles 22 and 23 and in the fifth clause of the preamble. December 10 is "International Human Rights Day” in memory of the declaration's adoption by the United Nations General Assembly.

332. See former U.S. president Jimmy Carter's lament about the American government's poor human rights record since 9/11, "A Cruel and Unusual Record,” New York Times, June 24, 2012.

333. Occasionally in American history, including in recent decades, individual states have tried to function as sites of regional opposition to the central government-the Civil War being the most well-known example. Calls for "states' rights" date back to Jefferson. However, their fight for independence on a single issue or policy, whether slavery, education, banking, or zoning, is usually of limited extent and duration since the central government's economic weight (not to mention its military might) can force states to comply with federal law. Nor is a regional power necessarily able to avoid reproducing a version of the arbitrary rule it may denounce at the national level, in other words the hypocrisy of the pot calling the kettle black.

334. See Federalist \#51: “... it is evident that each department should have a will of its own; and consequently should be so constituted that the members of each should have as little agency as possible in the appointment of its members... The interest of the man must be connected with the constitutional rights of the place. It may be a reflection on human nature that such devices should be necessary to control the abuses of government." Culture (i.e., "devices") must supplement man's imperfect (nonangelic, nonomniscient) nature. Note the 
deliberately impersonal constructions: the will is in "each department," and the rights are "of the place" not of the person.

335. John Dewey is occasionally looked to in today's embattled times, but not often enough. See, for example, Wesleyan University president Michael S. Roth, "Learning as Freedom," New York Times, September 6, 2012-a declaration that has many parallels with the concluding chapter of Huxley's Brave New World Revisited and other defenses of liberal education of the past sixty years.

336. To my knowledge, no country has sought to duplicate the National Collegiate Athletic Association (NCAA) within its higher education system.

337. See Jane Mayer on American Family Association leader Bryan Fischer, "Bully Pulpit: An Evangelist Talk-Show Host's Campaign to Control the Republican Party," New Yorker, June 18, 2012, 56-65.

338. "Now, in nations and times where men conceive a natural contempt for individual rights, the rights of society may naturally be extended and consolidated. In other words, men become less attached to particular rights at the very moment when it is perhaps most necessary to hold on to and defend the few such rights that still exist. (...) [T] rue friends of liberty and human grandeur must remain constantly vigilant and ready to prevent the social power from lightly sacrificing the particular rights of a few individuals to the general execution of its designs." Unlike in more aristocratic caste societies, in democratic societies where the part is more intimately related to the whole, a violation of individual rights tends "to deeply corrupt the national mores and to place the entire society in jeopardy" (G827). This thought was given dramatic representation in a memorable declaration by a fictional Sir Thomas More in Robert Bolt's play A Man for All Seasons (1960): “This country is planted thick with laws from coast to coast, Man's laws, not God's, and if you cut them down - and you're just the man to do it-do you really think you could stand upright in the winds that would blow then? Yes, I give the Devil benefit of law, for my own safety's sake!"

339. See the Wikipedia entry "Slow Food."

340. For sympathetic profiles of Apple, PepsiCo, and Pixar, see the May 16, 2011 issue of the New Yorker magazine: Malcolm Gladwell, "Creation Myth" (44-53), John Seabrook, "Snacks for a Fat Planet” (54-71), and Anthony Lane, "The Fun Factory” (74-87). This trio of you've-got-a-friend-in-me corporate profiles reveals its unspoken dark side when followed up by the next set of profiles in the same issue by Steve Coll, Lawrence Wright, and Jon Lee Anderson on Osama bin Laden's high-tech communications savvy ("The Outlaw") and the unintended consequences of U.S. involvement in Pakistan ("The Double Game") and Afghanistan ("Force and Futility"). 
341. Federalist \#51. This same paper, attributed to James Madison, contains these famous lines: "But what is government itself but the greatest of all reflections on human nature? If men were angels, no government would be necessary. If angels were to govern men, neither external nor internal controls on government would be necessary. In framing a government which is to be administered by men over men, the great difficulty lies in this: you must first enable the government to control the governed; and in the next place oblige it to control itself. A dependence on the people is, no doubt, the primary control on the government; but experience has taught mankind the necessity of auxiliary precautions." In other words, government is not the problem, man is the problem; but man has the ingenuity to craft a treatment, not a once and for all cure, to his own problem. The treatment Madison proposes is constitutional democracy, and The Federalist, largely endorsed by Tocqueville, is its justification and user's guide. 


\section{Conclusion}

To conclude, here are ten more specific policy recommendations that I believe would help nurture the civic conscience of society. I formulated them with North America and Western Europe in mind, but many of these recommendations could be helpful in other parts of the world that are struggling to establish more or better democratic institutions and habits.

1. Combat extreme inequality: If expanding equality of social conditions was the necessary condition for democracy to take hold in America, obviously a severe and abrupt reversal of that trend-in effect a culture of extreme inequality-is the greatest threat to democracy. Recently two French economists have done more than most to play Jiminy Cricket and denounce the lie that America has been telling itself since the Reagan era, namely that income inequality doesn't matter because there is socioeconomic mobility and equality of opportunity in America, anyone can get ahead who really wants to, etc. ${ }^{342}$ While on salary at American universities, Thomas Piketty and Emmanuel Saez did the grunt work into the history of income inequality between rich, middle class, and poor in developed countries over the past one hundred years and presented it clearly in a series of publications that have also exposed the meritocracy myth of high socioeconomic mobility in America. ${ }^{343}$ Their findings have been relayed in major media by business journalists such as Adam Davidson and Eduardo Porter. Their research also put teeth into the Occupy Wall Street movement in 2011 and fueled President Obama's that's-not-classwarfare-that's-common-sense reelection campaign in $2012 .{ }^{344}$ The thrust of Porter's work is to present in layman's terms the research that shows high inequality countries, as defined by the so-called Gini index, have more trouble sustaining economic growth and often experience "painful contractions." 
It's not too hard to see why. Extreme inequality blocks opportunity for the poor. It can breed resentment and political instability-discouraging investment-and lead to political polarization and gridlock, splitting the political system into haves and have-nots. And it can make it harder for governments to address economic imbalances and brewing crises. ${ }^{345}$

These statements echo Davidson's paraphrase of the book-length treatment of the same subject by Acemoglu and Robinson in Why Nations Fail (2012). ${ }^{346}$ Before his death in 2010, Tony Judt made the same case in Ill Fares the Land, borrowing a chart from Wilkinson and Pickett's The Spirit Level $(I l l, 15)$ that casts serious doubt on the standard Republican claim that high social mobility makes up for income inequality. ${ }^{347} \mathrm{On}$ the contrary, the chart shows that more egalitarian countries (Denmark, Canada, Germany, etc.) have much higher rates of social mobility (the possibility of moving between income quintiles during one's working years) than do high inequality countries such as the United States.

It's important to recall that political equality, not economic inequality, was uppermost in Tocqueville's mind in the 1830s and that he did not live long enough to experience the Gilded Age in America or the conspicuous consumption during the Second Empire in his own country. It was clear however to anyone who did live through those times that economic inequality must be addressed simultaneously with political equality, as many Progressive Era academics, labor leaders, politicians, and judges, such as Louis D. Brandeis, consistently repeated. ${ }^{348}$

Other pro-democracy measures, many tributary to the fight against extreme inequality, would include the following:

2. Combat excess individualism, excess materialism, and exaggerated focus on the present: Go outside. Live one day per week without spending money, wearing headphones or a watch, or carrying your phone. If that's too much, try it for one morning or afternoon per week. The preservation of the world may be in wildness ... and occasional unwiredness.

3. Restore the sacredness of the electoral process and of elective office: Remember that serving in government is "an honor not a career" as Warren Buffett recalls in his "Congressional reform act 2011." Other specific changes must include: 
Election reform: encourage mandatory voter registration, early voting, uniform paper voting procedures, and tighter rules and limits on fundraising and campaign advertising; discourage excess polling, exit polling, and cynical voter ID requirements that disguise a vote suppression tactic behind appeals to "common sense" and fraud prevention.

Congressional reform: term limits, accountability for conflict of interest violations, elimination of gerrymandering.

Judicial reform: no elected judges, long-term contracts, eighteen years, no life appointments.

Presidential/governor reform: campaign finance reform, term limits, clearer definition of powers and limits on power.

4. Combat isolation and immunity: Invest in public spaces (libraries, parks, museums, malls, festivals) that foster chance encounters, discoveries, and rediscoveries that get people out of their isolated niches and comfort zones once in awhile. Invest in public education. Reaffirm education as a public good open to all, not a private good reserved for those who can afford it. Invest in affordable public transportation (trains, tramways, buses, bicycles). Establish a flexible two-year mandatory national service requirement for men and women with military and nonmilitary options (avoid using the words draft and conscription with their negative connotations).

5. Combat corruption, crime, and low accountability: Defend the rule of law (transparency, accountability, consequences). Defend an open independent judiciary and the dignity of the legal professions.

6. Combat the worship of change and mobility: Underline the high cost, to individuals and communities, of homesickness, dislocation, relocation, and so-called creative destruction.

7. Combat the worship of get-rich-quick and get-something-for-nothing schemes: For example, governments should not associate their names with gambling and the "state lottery" and ought to devote a part of the tax revenues derived from state-supervised private gambling to public information campaigns about the risk of addiction and gambling addiction counseling. Tell citizens the truth about low socioeconomic mobility to debunk "rags to riches" daydreaming. Encourage effort and reward substantive achievements, not mere participation. 
8. Combat the dogma that private is always better than public: Use public-private partnerships to fund, build, and maintain open, affordable access to institutions that enhance human wellness (sports facilities, libraries, museums, parks). Build and defend affordable public health care and health insurance systems as a human right (as per education). Build and defend affordable public transportation systems (on economic, ecologic, and civic grounds).

9. Defend an open, affordable Internet: An Internet that is not focused merely on commerce and exploitation but devoted to expanding user access to products, services, knowledge, and experiences that build trust, love, fun, and ordinary empowerment. Defend Internet freedom while pursuing abusers and Internet criminals.

10. Defend individual rights as listed in the Universal Declaration of Human Rights.

Many of these recommendations are not new, and some, such as the bill in favor of "Universal National Service," have languished in the U.S. Congress for years. Others, such as the "Stop Online Piracy Act," have been met with swift opposition that has forced both sides back to the drawing board to come up with better solutions to strike the proper balance of a free but regulated civil society, including the Internet. Despite these setbacks, however, serious discussions and actual work on all of the above ten recommendations continues. And there is more constructive criticism of democracy's strengths and weaknesses going on around the world, as well as concrete reform proposals being hammered out and implemented, than ever before. Perhaps most visibly, the "Occupy" movements have raised awareness that democracy is unsustainable without a robust middle class. Many cities in Europe and America have strengthened their commitment to public transportation systems (including low-cost bike rental networks), as well as to quality public education and health care. France curbed its long-standing attachment to a monarchical style presidency by instituting term limits and reasserting the limits of presidential immunity. In the United States, just as most people eventually accepted seat belts and motorcycle helmets, the country seems to be coming around slowly but surely to the idea that it's not okay for fifty million of its citizens to have no health insurance, and an important provision of a major health care reform act that requires individuals to 
take out health insurance was recently upheld by a 5-4 vote of the U.S. Supreme Court. ${ }^{349}$ The right to "marriage equality" has been granted in many countries recently (e.g., Spain, Argentina) and is making progress in many others. To get around the inconvenience and voter suppression of Tuesday voting, user-friendly early voting procedures have been established in many American states-a development that significantly enhances voter dignity by allowing for less rushed and more thoughtful voting, combats the delegitimating effect of high abstention rates by facilitating higher levels of participation, and therefore strengthens representative democracy. Many Internet media have incorporated "reader comments" as a standard supplement, and those "threads" have become an integral part of the news cycle that in some ways is as important as the "news" itself. Canadians have recently pushed back against the privatization of their higher education system, and France too has so far resisted following Britain's experiment with sharply higher university fees that risk lowering access and narrowing educational paths and career options as students take on more debt. The "unmaking of the public university" in the U.S. over the past forty years has been met with increasing opposition in California and elsewhere, and there are many signs that real actions are being taken to save American colleges and universities, put the focus back on knowledge and know-how (instead of on sports and socializing), and make higher education both affordable and valuable for the middle class.

My point is that there have been many small victories on the democracy and dignity fronts on every continent in the last twenty-five years, even though it would be incorrect to exaggerate their importance and impact at this early stage. The "specter of inverted totalitarianism" (Wolin), "the forty-year assault on the middle class" (Newfield), and "the culture of extreme inequality" (Ehrenreich) are real, cannot be wished away, and will likely take at least one or two generations to undo. If Tocqueville is right when he asserts that mores, not laws or geohistorical circumstances, are the most important factor in maintaining the democratic republic in the United States ( $D A I, 2,9)$, it must be remembered that mores are deeply ingrained customs and habits that reflect long-standing value judgments, and as such they don't change quickly 
or without resistance, even when groups of individuals might express a desire for change.

It is clearly democracy's gradual drift into nondemocracy that has Rahe, Heimonet, Wolin, and many other democracy auditors worried... and working in different ways around the world to reverse. Democracy skeptics, of course, don't mind the "managed democracy" that has gripped not just Russia but civil society in the U.S., Great Britain, France, and elsewhere. Many have been angling for it all along, and they are quick to assert, usually from a stable perch of power and privilege, that "there is no alternative" and "it could always be worse" (i.e., gridlock or corruption is better than, say, mass starvation or genocide). Indeed things could always be worse, which is why Tocqueville was willing to express understanding for the "soft despotism" of managed democracy even though he held out hope for something better.

But no society, whether democratic, partly democratic, or outright authoritarian, can exist without an $u s$, and it is generally acknowledged today, based on the last three centuries of various experiments in governance, that dignity-based democracies — not oligarchies-have the advantage of forging the most authentic and least phony or hypocritical us. And they often turn out to build the most fun, prosperous, and sustainable societies as well. The U.S., starting with its famous, "We the people," has demonstrated this to the world more successfully throughout its history than any other country, though not without some serious challenges to the union (and its civic conscience) along the way, such as in 1781-1787, 1850, 1860-1865, 1876 (the disputed election of Hayes), 1886 (the Haymarket affair), 1963 (the March on Washington), 2000 (the disputed election of George W. Bush) ... and now!

Therefore, if there is one thing to take away from reading Tocqueville's Democracy in America today it is that the defense of human dignity and the conservation and practice of healthy democratic mores are still worthwhile pursuits in the Internet Age. 


\section{Notes}

342. Among American researchers, the work of Thomas B. Edsall has for long been exemplary. See, for example, his latest response to the Reaganesque right, “The Hidden Prosperity of the Poor,” New York Times, January 30, 2013.

343. Many of Piketty's publications, in French and English, are available through his professional website: <http://piketty.pse.ens.fr/fr/>. The same is true for Emmanuel Saez: <http://elsa.berkeley.edu/ saez/>.

344. For a brief history of the Piketty-Saez effect see Annie Lowrey, "For Two Economists, The Buffet Rule Is Just a Start,” New York Times, April 16, 2012. For a more in-depth look at the debate launched by the Piketty-Saez claims, see Thomas B. Edsall, “The Fight over Inequality,” New York Times, April 22, 2012. See President Obama's 2012 "State of the Union Address” for the class warfare versus common sense remarks. <http://www.nytimes. com/interactive/2012/01/24/us/politics/state-of-the-union-2012-videotranscript.html>. Video with full-text transcript, accessed July 7, 2012.

345. Eduardo Porter, “The 1 Percent Club’s Misguided Protectors,” New York Times, December 10, 2011.

346. Adam Davidson, "Why Some Countries Go Bust," New York Times, March 13,2012 . The idea that democracy is actually better for business than authoritarian approaches is one of the main claims in Christopher Newfield's essay "Recapturing Academic Business," in Chalk Lines: The Politics of Work in the Managed University, ed. Randy Martin (Durham: Duke University Press, 1998), 69-102. See also Anthony Lane's sympathetic profile of the “democratic initiative" at Pixar (op. cit., 87).

347. Another overview of the inequality question that does not mention Piketty or Saez but does include the customary nod to Tocqueville while reviewing Judt's Ill Fares the Land and six other recent "grand strategy" books is Nicolas Lehmann's "Evening the Odds: Is There a Politics of Inequality?" New Yorker, April 23, 2012, 69-73.

348. For a call in favor of a new Progressive Era to oppose the new inequality in America, see Jeffrey D. Sachs, “The New Progressive Movement,” New York Times, November 12, 2011. For a history of the Progressive Era, see Richard Hofstadter, The Age of Reform (1955); and Robert Wiebe, The Search for Order: 1877-1920 (1967). For a tax reform proposal inspired by Brandeis- "We may have democracy, or we may have wealth concentrated in the hands of a few, but we cannot have both" - see Ian Ayres and Aaron S. Edlin, "Don't Tax the Rich. Tax Inequality Itself,” New York Times, December 18, 2011.

349. For a commentary of that decision, see Jeffrey Toobin, “To Your Health,” New Yorker, July 9 \& 16, 2012, 29-30. 



\section{Appendix}

Here are the answers to the twenty questions listed at the end of Part One, Chapter One. Each answer below should be understood as beginning with "According to Tocqueville."

1. What are three of the original conditions that favored the spread of democracy among the Anglo-Saxon people in North America? (I, 1, ii)(1) A high level of given (not earned) equality with a common language, the same or similar religion (mostly forms of Protestantism), a similar middling level of education and socioeconomic standing (not stupid or poor); (2) they were accustomed to rights and laws; (3) they were accustomed to self-governance.

2. When studying democracy in America, why is it necessary to examine what happens in individual states before considering the union as a whole? (I, 1, v)Because at the state and local level one can best witness the operation of "community spirit" (common people working together to treat matters of common interest) which is the lifeblood of self-governance, i.e., democracy.

3. Why do the citizens of democratic lands often elect mediocre governors? (I, 2, v) They often elect mediocre leaders because they lack the time and intelligence to choose better ones; because the best men tend to be attracted to commerce and industry instead of politics; because the best men can have a negative image of politics as something dirty that they prefer to avoid; and because citizens in democratic lands can envy high achievers and (as a perverse sort of passive-aggressive revenge) prefer a flawed ordinary person over a manifestly more qualified and promising candidate.

4. What are the real advantages derived by American society from democratic government? (I, 2, vi)Democracy encourages many positive/healthy things including the well-being of 
the greatest number; public spiritedness ("rational patriotism"); respect for rights and law; productivity, confidence, and selfesteem. Democracy also makes repairable mistakes.

5. How does the majority in a democratic land become tyrannical? (I, 2, vii)A majority in a democratic land can become tyrannical when it exploits its mere numerical advantage without reasoned arguments (thus substituting "higher numbers make right" for "might makes right"); when it ceases to acknowledge or be responsive to alternative minority views - in effect becoming deaf and blind; when it ceases to recognize a higher law above itself-often called "justice," "divine justice," or "God's will”; or when it ceases to even tolerate alternative minority views (through the practice of mild or aggressive forms of censorship, for example); when it multiplies constraints on fundamental human rights (to equal dignity, for example) and on fundamental freedoms of speech and free association.

6. What moderates the tyranny of the majority in the United States? (I, 2, viii) The absence of a central administration (unlike France); the legal community (especially its brainy dimension, the fact that lawyers and judges necessarily rely on argument and memory and these can counteract the sometimes headless and heedless "mob" dimension of majority rule); juries and jury duty (a continuous experiential education opportunity for citizens to learn about citizenship and self-governance through doing it).

7. What are the main causes that tend to maintain a democratic republic in the United States? (I, 2, ix)Favorable geographic circumstances (size, abundant resources, rival powers distant); the long-standing systematic rule of law; mores ("mœurs").

8. What are the main characteristics of the American philosophic method? (II, 1, I)Pragmatism; a distaste for rigid methods, systems, and forms; self-reliance (as opposed to reliance on traditions, famous predecessors, or outside authorities); antifoundationalist. Americans are Cartesians who mostly have not read a word of Descartes. 
9. Why do Americans show more aptitude and taste for general ideas than the British? (II, 1, iii)Americans' belief in equality combined with a desire to move quickly and efficiently makes them attracted to generalizing and inductive thinking (extrapolating, transferring), whereas the British with their tradition of class-consciousness and castes are more inclined to focus on the specificity of particular cases, less open to universalist talk and transferability, and more skeptical about inductive reasoning.

10. Why have Americans never been as enthusiastic as the French for general ideas, especially in political matters? (II, 1, iv)Despite being more comfortable with generalizing and universalism than the British, Americans are nevertheless confronted with the real experience of decision making more than the French, who are often kept on the sidelines or in the classroom or "salon" and thus are more inclined toward theory and abstraction because they have less practical experience with which to counterbalance itunlike Americans who are regularly agents confronting real cases and learning from doing.

11. How does religion in America benefit and benefit from democratic tendencies? (II, 1, v)Religion allows Americans to have some matters settled and not open to doubting or questioningwhich is time-consuming and debilitating (see Hamlet). Thus religion frees the mind and body for other things - notably business and industry. Conversely, democracy benefits religion by leaving it free to go about its spiritual business within its own spherenamely the eternal, the immaterial, and the transpersonal. There is a live and let live attitude between the civil society and religions within a democracy. Religion brings together ordinary democratic people (who are easily absorbed by self-centered individualism, i.e., an impatient, perhaps even reckless pursuit of material wellbeing) for a shared experience of calm, considered reflection on larger purposes that are not about just me, money, now. Religion counteracts some of democracy's negative side effects and vice versa. Democracy's openness can help curb religion's excessive 
dogmatism, abstraction, and insularity, and thus they act as checks and balances on each other.

12. Why is the study of Latin and Greek beneficial in democratic countries? (I, 1, xv) The study of Latin and Greek is beneficial (even if practiced only by a minority) because it counterbalances negative tendencies in democratic countries (namely impatience, inattention to detail, aversion to difficulty, desire for the cheap, fast, and easy, and lack of respect for history) — “C'est un hygiène salutaire."

13. Why is theater so successful in democratic nations? (II, 1, xix)Because you don't have to be that smart to enjoy it. Unlike with novels and epic poetry, theater requires no higher literacy (no knowledge of rhetorical figures, allegories, cultural allusions) and no strong powers of memory. Most plays (and Broadway shows and movies) can be easily appreciated by the masses.

14. Why do democratic nations display a more passionate and lasting love for equality than for freedom? (II, 2, i) The benefits of equality come easily and immediately, those of freedom/liberty require more effort and time; liberty has been more recently acquired (by most demolanders) and is therefore more easily given up ("Easy come, easy go."); equality being the distinctive feature of the modern age, it is that to which most people are most attached; the fragility of freedom makes attachment to it less strong in practice; men typically notice the negative side effects of extreme liberty (license, recklessness, anarchy) more easily than they do the negative side of extreme equality (sterile conformism, timidity, stagnation); equality can be granted to everyone with little individual effort, whereas liberty usually requires personal labor that, moreover, must be continuously renewed.

15. How do Americans combat the effects of individualism with free institutions? (II, 2, iv)Thanks to free institutions (i.e., systems and services that are low-cost or free and freely accessible, e.g., the press, associations, voting, public libraries, town meetings, juries, public post office, the Internet), Americans have ample opportunities to get outside of themselves and their own little preoccupations and consider the larger issues faced by their village, 
town, city, country, or the entire world. Moreover, Americans are regularly and sincerely invited to get involved in these free institutions - to write "letters to the editor," for example - and by so doing they are forced (once they accept the invitation) to consider what they think and why (or change views) and communicate their reasoned convictions to others, and not only to people who are already predisposed to agree with them. Making these institutions free and open, or nearly so, encourages high levels of voluntary participation, which is the best kind to insure the cultivation of rational patriotism, aka community spirit, and continuous respect for rights and laws.

16. How do Americans counteract individualism by the doctrine of self-interest properly understood? (II, 2, viii)The doctrine of "self-interest properly understood" (intérêt bien entendu) is the core of rational patriotism and community spirit: the considered belief that my interests and the interests of the larger community/ country overlap to a large extent. This doctrine demonstrates that individualism and community spirit are not mutually exclusive but can actually reinforce each other: because men are mostly relatively weak, they must cooperate, and in fact they voluntarily seek each other out to do so-a "win-win" situation-for barn raising, apple picking, hay making, etc.

17. Why are Americans so restless in the midst of their prosperity? (II, 2, xiii)Fear of falling. Americans seek to overcome their relative weakness, but those who manage to do so are rarely satisfied with their acquired strength and instead always seek to become stronger still as a sort of never-ending insurance policy against "losing it all." A second factor is a thirst for perfection (the best) on the part of people who themselves are for the most part less than perfect and if pressed would grudgingly acknowledge their own lack (of intellect, training, patience, passion) that holds them back. Demolanders know they are not the aristoi-the smartest, the richest, the bravest, the most good-looking-but would still like to be "a contender" or own a piece of the best-either really or in some fantasy realm. 
18. What is the influence of democracy on the family? (II, 3, viii)Relations between family members (father/son, husband/ wife, siblings) are generally softer and looser (because not weighted down with centuries of authoritarian tradition and suspicious rivalry), but they are also rather rigorist as a result of a contractual attitude that is brought to these relations. Girls and wives in particular are encouraged to be better educated and wellinformed about their matrimonial choices, but they are confined to the domestic sphere for the most part, and any desire to change the terms of the agreement that is entered into (through divorce or extramarital affairs, for example) is socially unacceptable.

19. How is it that Americans can be generally serious and yet sometimes behave recklessly? (II, 3, xv) They are typically serious because they are involved in the political process in high numbers, either as voters or elected officials, or both; but they are occasionally reckless because they have neither the time, interest and attention, or intelligence to carry out their responsibilities wisely and thoroughly.

20. Why do democratic nations have a natural desire for peace while the armies within democratic nations naturally seek war? (II, 3, xxii)War is bad for business and industry, except for the "business" of war, and so while all those in civil society are generally opposed to war (except for defense contractors), military personnel generally favor war since it is their means of obtaining distinctions and promotions, i.e., "career advancement." 


\section{Bibliography}

Note: Many of the works listed below contain further extensive bibliographies.

\section{Tocqueville in French}

Tocqueville, Alexis de. De la démocratie en Amérique (2 vols. 1835, 1840). Ed. François Furet. Paris: Garnier-Flammarion (G-F), 1981.

Tocqueville, Alexis de. L'Ancien régime et la révolution (1856). Ed. J.-P. Mayer. Paris: Gallimard/Folio, 1967.

Tocqueville, Alexis de. Souvenirs (1850-1851). Ed. J.-P. Mayer, L. Monnier, and B. M. Wicks-Boisson. Paris: Gallimard/Folio, 1999 [1964], 1999.

Tocqueville, Alexis de. Lettres Choisies, Souvenirs (1814-1859). Ed. Laurence Gellac and Françoise Mélonio. Paris: Gallimard/Quarto, 2003.

Tocqueville, Alexis de. Oeuvres: Tomes I, II, III. Paris: Gallimard / Bibliothèque de Pléiade, 1991, 1992, 2004.

\section{Tocqueville in English}

Tocqueville, Alexis de. Democracy in America. Trans. Gerald E. Bevan with an introduction by Isaac Kramnick. London: Penguin, 2003.

Tocqueville, Alexis de. Democracy in America. Trans. Arthur Goldhammer with a chronology by Olivier Zunz and notes by Goldhammer and Zunz. New York: Library of America, 2004.

Tocqueville, Alexis de. Democracy in America. Trans. Harvey C. Mansfield and Delba Winthrop with introduction. Chicago: University of Chicago Press, 2000.

Tocqueville, Alexis de. Democracy in America. Ed. Isaac Kramnick. Trans. Henry Reeve. New York: Norton, 2007.

Tocqueville, Alexis de. Democracy in America. Ed. J. P. Mayer. Trans. George Lawrence. New York: Anchor, 1969 [Harper \& Row, 1966].

Tocqueville, Alexis de. Democracy in America. Ed. Phillips Bradley. Trans. Henry Reeve. New York: Knopf, 1990 [1945]. 
Tocqueville, Alexis de. Democracy in America (abridged). Trans. Stephen D. Grant with an introduction by Sanford Kessler. Indianapolis: Hackett Publishing, 2000.

Tocqueville, Alexis de. Democracy in America (abridged). Ed. Michael Kammen. Trans. Elizabeth Trapnell Rawlings. New York: Bedford / St. Martin's, 2008.

Tocqueville, Alexis de. Democracy in America (abridged). Ed. Scott Sandage. Trans. George Lawrence. New York: HarperCollins, 2008.

Tocqueville, Alexis de. Ancien Regime and the French Revolution. Trans. Gerald Bevan. London: Penguin, 2008.

Tocqueville, Alexis de. The Old Regime and the French Revolution. Trans. Stuart Gilbert. New York: Anchor, 1955.

Tocqueville, Alexis de. Tocqueville: The Ancien Régime and the French Revolution. Cambridge Texts in The History of Political Thought. Ed. Jon Elster. Trans. Arthur Goldhammer. Cambridge: Cambridge University Press, 2011.

Tocqueville, Alexis de. The Recollections of Alexis de Tocqueville. Trans. Alexander Teixeira de Mattos. New York: Macmillan, 1896.

Tocqueville, Alexis de. Recollections: The French Revolution of 1848. Ed. J. P. Mayer and A. P. Kerr. Piscataway, NJ: Transaction Publishers, 1987.

Tocqueville, Alexis de. Letters from America: Alexis de Tocqueville. Ed., trans., and with an introduction by Frederick Brown. New Haven: Yale University Press, 2010.

Tocqueville, Alexis de. Selected Letters on Politics and Society. Ed. Roger Boesche. Trans. Roger Boesche and James Toupin. Berkeley: University of California Press, 1985.

Tocqueville, Alexis de. Writings on Empire and Slavery. Ed. and trans. Jennifer Pitts. Baltimore: Johns Hopkins University Press, 2003.

Tocqueville, Alexis de. Alexis de Tocqueville's Journey in Ireland: July-August 1835. Ed. and trans. Emmet Larkin. Washington, DC: Catholic University of America Press, 1990.

Tocqueville, Alexis de. Alexis de Tocqueville and Gustave de Beaumont in America: Their Friendship and Their Travels. Trans. Arthur Goldhammer. Charlottesville: University of Virginia Press, 2010.

Tocqueville, Alexis de. Tocqueville on America after 1840: Letters and Other Writings. Ed. and trans. Aurelian Craiutu and Jeremy Jennings. Cambridge: Cambridge University Press, 2009. 


\section{A Selection of Tocqueville Studies in French}

Amiel, Anne. Le Vocabulaire de Tocqueville. Paris: Ellipses Marketing, 2002.

Antoine, Agnès. L'Impensé de la démocratie: Tocqueville, la citoyenneté et la religion. Paris: Fayard, 2003.

Aron, Raymond. Les Étapes de la pensée sociologique. Paris: Gallimard Tel, 1967.

Audier, Serge. Tocqueville retrouvé: Genèse et enjeux du renouveau tocquevillien français. Paris: Vrin EHESS, 2004.

Benoît, Jean-Louis. Tocqueville: Un destin paradoxal. Paris: Bayard, 2005.

Boudon, Raymond. Tocqueville aujourd'hui. Paris: Odile Jacob, 2005.

Coenen-Huther, Jacques. Tocqueville. Paris: Presses Universitaires de France (PUF: Que sais-je?), 1997.

De Robien, Gilles. Alexis de Tocqueville. Paris: Flammarion, 2000.

Dubois, Christian. Alexis de Tocqueville: Vie, oeuvres, concepts. Paris: Ellipses, 2004.

Frioux, Dalibor. De la démocratie en Amérique de Tocqueville (avec le texte du tome II, partie 1, chapitres 1-8). Paris: Bréal (Philothèque), 2002.

Guellec, Laurence, ed. Tocqueville et l'esprit: The Tocqueville Review / La Revue Tocqueville. Paris: Les Presses Sciences Po, 2005.

Guineret, Hervé. Tocqueville: De la guerre au colonialisme. Paris: Ellipses, 2007.

Heimonet, Jean-Michel. Tocqueville et le devenir de la démocratie: La perversion de l'idéal. Paris: L'Harmattan, 1999.

Jardin, André. Alexis de Tocqueville 1805-1859. Paris: Hachette, 2005.

Jaume, Lucien. Tocqueville: Les sources aristocratiques de la liberté. Paris: Fayard, 2008.

Lafitte, Jacqueline, and Jean-Paul Lafitte. De la démocratie en Amérique 4e partie du tome II (Analyse et commentaire autour de l'œuvre). Paris: Nathan, 2004.

Le Strat, Claire, and Willy Pelletier. La Canonisation libérale de Tocqueville. Paris: Éditions Syllepse, 2005.

Manent, Pierre. Tocqueville et la nature de la démocratie. Paris: Gallimard Tel, 1982, 1993, 2006.

Mélonio, Françoise. Tocqueville et les français. Paris: Aubier, 1993. 


\section{A Selection of Tocqueville Studies in English}

Allen, Barbara. Tocqueville, Covenant, and the Democratic Revolution: Harmonizing Earth with Heaven. Idaho Falls: Lexington Books, 2005.

Atananassow, Ewa and Richard Boyd, eds. Tocqueville and the Frontiers of Democracy. Cambridge: Cambridge University Press, 2013.

Bessette, Murray. Alexis de Tocqueville and the Challenges of American Society. Lulu.com, 2008.

Boesche, Roger. Tocqueville's Road Map: Methodology, Liberalism, Revolution, and Despotism. Idaho Falls: Lexington Books, 2007 [2006].

Boesche, Roger. The Strange Liberalism of Alexis de Tocqueville. Ithaca: Cornell University Press, 1987.

Brogan, Hugh. Alexis de Tocqueville: Prophet of Democracy in the Age of Revolution. New Haven: Yale University Press, 2007.

Craiutu, Aurelian, and Sheldon Gellar, eds. Conversations with Tocqueville: The Global Democratic Revolution in the Twenty-First Century. Idaho Falls: Lexington Books, 2009.

Damrosch, Leo. Tocqueville's Discovery of America. New York: Farrar, Straus and Giroux, 2010.

Danoff, Brian. Educating Democracy: Alexis de Tocqueville and Leadership in America. Albany: State University of New York Press, 2010.

Danoff, Brian, and L. Joseph Hebert, Jr., eds. Alexis de Tocqueville and the Art of Democratic Statesmanship. Idaho Falls: Lexington Books, 2010.

Edwards, Bob, with Michael Foley and Mario Diani, eds. Beyond Tocqueville: Civil Society and the Social Capital Debate in Comparative Perspective. Civil Society: Historical and Comparative Perspectives. Hanover, NH: University Press of New England, 2001.

Elster, Jon. Alexis de Tocqueville: The First Social Scientist. Cambridge: Cambridge University Press, 2009.

Epstein, Joseph. Alexis de Tocqueville: Democracy's Guide. Eminent Lives. New York: HarperCollins, 2006.

Featherstone, Mark. Tocqueville's Virus: Utopia and Dystopia in Western Social and Political Thought. London: Routledge, 2007.

Hebert, L. Joseph, Jr. More than Kings and Less than Men: Tocqueville on the Promise and Perils of Democratic Individualism. Idaho Falls: Lexington Books, 2010. 
Henri-Lévy, Bernard. American Vertigo: Traveling America in Tocqueville's Footsteps. Trans. Charlotte Mandell. New York: Random House, 2007 [2006].

Janara, Laura. Democracy Growing Up: Authority, Autonomy, and Passion in Tocqueville's Democracy in America. Albany: State University of New York Press, 2002.

Kahan, Alan S. Alexis de Tocqueville: Major Conservative and Libertarian Thinkers. New York: Continuum, 2010.

Kaledin, Arthur. Tocqueville and His America: A Darker Horizon. New Haven: Yale University Press, 2011.

Kessler, Sanford. Tocqueville's Civil Religion: American Christianity and the Prospects for Freedom. Albany: State University of New York Press, 1994.

LaCapra, Dominick. History and Reading: Tocqueville, Foucault, French Studies. Toronto: University of Toronto Press, 2000.

Lamberti, Jean-Claude. Tocqueville and the Two Democracies. Trans. Arthur Goldhammer. Cambridge, MA: Harvard University Press, 1989.

Lawler, Peter Augustine, ed. Democracy and Its Friendly Critics: Tocqueville and Political Life Today. Lanham, MD: Lexington Books, 2004.

Leeden, Michael. Tocqueville on American Character: New York: St. Martin's Press, 2000.

Lerner, Max. Tocqueville and American Civilization. Piscataway: Transaction Publishing, 1994 [Harper and Row, 1969].

Levy, Jonah D. Tocqueville's Revenge: State, Society, and Economy in Contemporary France. Cambridge, MA: Harvard University Press, 1999.

Locke, Jill, and Eileen Hunt Botting, eds. Feminist Interpretations of Alexis de Tocqueville. University Park: Pennsylvania State University Press, 2009.

Mancini, Matthew. Alexis de Tocqueville and American Intellectuals: From His Time to Ours. Lanham, MD: Rowman and Littlefield, 2005.

Manent, Pierre. Tocqueville and the Nature of Democracy. Trans. John Waggoner. Foreword by Harvey C. Mansfield. London: Rowman and Littlefield, 1996. A translation from the French of Tocqueville et la nature de la démocratie (Paris: Gallimard, 1982).

Mansfield, Harvey C. Tocqueville: A Very Short Introduction. Oxford: Oxford University Press, 2010.

Mélonio, Françoise. Tocqueville and the French. Trans. Beth G. Raps. Charlottesville: University of Virginia Press, 1998. 
Mitchell, Harvey. America after Tocqueville: Democracy against Difference. Cambridge: Cambridge University Press, 2006.

Mitchell, Harvey. Individual Choice and the Structures of History: Alexis de Tocqueville as Historian Reappraised. Cambridge: Cambridge University Press, 2006.

Mitchell, Joshua. The Fragility of Freedom: Tocqueville on Religion, Democracy, and the American Future. Chicago: University of Chicago Press, 1995.

Mitchell, Joshua. Tocqueville in Arabia: Dilemmas in a Democratic Age. Chicago: University of Chicago Press, 2013.

Offe, Claus. Reflections on America: Tocqueville, Weber, and Adorno in the United States. Cambridge: Polity, 2005. A translation from the German of Selbtbetrachtung aus der Ferne: Tocqueville, Weber und Adorno in den Vereinigten Staaten (Frankfurt: Suhrkamp, 2004).

Ostrom, Vincent. The Meaning of Democracy and the Vulnerabilities of Democracies: A Response to Tocqueville's Challenge. Ann Arbor: University of Michigan Press, 1997.

Pierson, George W. Tocqueville in America. Baltimore: Johns Hopkins University Press, 1996. Reprint of George Wilson Pierson, Tocqueville and Beaumont in America (Oxford: Oxford University Press, 1938).

Rahe, Paul A. Soft Despotism, Democracy's Drift: Montesquieu, Rousseau, Tocqueville, and the Modern Prospect. New Haven: Yale University Press, 2009.

Raico, Ralph, and Jörg Guido Hülsmann. The Place of Religion in the Liberal Philosophy of Tocqueville, Constant, and Lord Acton. Auburn, AL: Ludwig Von Mises Institute, 2010 .

Schleifer, James T. The Making of Tocqueville's Democracy in America. Indianapolis: Liberty Fund, 2000 [1980].

Schleifer, James T. The Chicago Companion to Tocqueville's Democracy in America. Chicago: University of Chicago Press, 2012.

Welch, Cheryl B. De Tocqueville (Founders of Modern Political and Social Thought). Oxford: Oxford University Press, 2001.

Welch, Cheryl B., ed. The Cambridge Companion to Tocqueville. London: Cambridge University Press, 2006.

Williamson, Chilton. After Tocqueville: The Promise and Failure of Democracy. Wilmington: Intercollegiate Studies Institute, 2012.

Wolin, Sheldon S. Tocqueville between Two Worlds: The Making of a Political and Theoretical Life. Princeton: Princeton University Press, 2001. 
Ziccardi, James M. Fundamental Alexis de Tocqueville: A Practical Guide to Democracy in America. Createspace Independent Publishing Platform, 2011.

Zunz, Olivier, and Alan S. Kahan, eds. The Tocqueville Reader: A Life in Letters and Politics. Hoboken: Wiley-Blackwell, 2002.

\section{A Selection of Democracy Studies in French}

Aron, Raymond. Les Étapes de la pensée sociologique. Paris: Gallimard, 1976.

Aron, Raymond. Démocratie et totalitarisme. Paris: Gallimard, 1987.

Aron, Raymond. L'Opium des intellectuals. Paris: Fayard/Pluriel, 2010 [1955].

Attali, Jacques. Demain, qui gouvernera le monde? Paris: Fayard, 2011.

Baudrillard, Jean. Amérique. Paris: Le Livre de Poche, 1988.

Brugère, Fabienne. Faut-il se révolter. Paris: Bayard Jeunesse, 2012.

Brugère, Fabienne L'Éthique du care. Paris: Presses Universitaires de France (PUF: Que sais-je?), 2011.

Furet, François. Penser la révolution française. Paris: Gallimard/Folio, 1985.

Gauchet, Marcel. L'Avènement de la démocratie: Tome 1, La révolution moderne. Paris: Gallimard, 2007.

Gauchet, Marcel. L'Avènement de la démocratie: Tome 2, La crise du libéralisme, 18801914. Paris: Gallimard, 2007.

Gauchet, Marcel. La Religion dans la démocratie. Paris: Gallimard/Folio, 2001.

Heimonet, Jean-Michel. La démocratie en mal d'alterité: Masse et terreur, réflexions sur l'informe du pouvoir moderne. Paris: L'Harmattan, 2003.

Heimonet, Jean-Michel. Les Deux faces du terrorisme et l'autodestruction des sociétés ouvertes. Paris: Kimé, 2005.

Heimonet, Jean-Michel. La raison démocratique dans les limites du religieux: Terreur intellectuelle à l'âge postmoderne. Paris: Cécile Defaut, 2007.

Laugier, Sandra. Pourquoi désobéir en démocratie? Paris: La Découverte, 2011.

Laugier, Sandra. Une autre pensée politique américaine: La Démocratie radicale d'Emerson à Stanley Cavell. Paris: Michel Houdiard, 2004.

Lefort, Claude. L'Invention démocratique: Les limites de domination totalitaire. Paris: Fayard, 1994. 
Manent, Pierre. La Raison des nations: Réflexions sur la démocratie en Europe. Paris: Gallimard, 2006.

Rancière, Jacques. La Haine de la démocratie. Paris: La Fabrique éditions, 2005.

Rosanvallon, Pierre. La société des égaux. Paris: Seuil, 2011.

Rosanvallon, Pierre. La légitimité démocratique: Impartialité, réflexivité, proximité. Paris: Seuil/Points, 2010.

Rosanvallon, Pierre. La contre-démocratie: La Politique à l'âge de la défiance. Paris: Seuil/Points, 2008.

Rosanvallon, Pierre. La démocratie inachevée: Histoire de la souveraineté du people en France. Paris: Gallimard, 2003.

Todd, Emmanuel. Après la démocratie. Paris: Seuil, 2008.

\section{A Selection of Democracy Studies in English}

Bellah, Robert N., with Richard Madsen, William M. Sullivan, Ann Swidler, and Steven M. Tipton. Habits of the Heart: Individualism and Commitment in American Life. 3rd ed. Berkeley: University of California Press, 2007 [1985].

Beetham, David, and Kevin Boyle. Introducing Democracy: 80 Questions and Answers. Cambridge: Polity/UNESCO, 1995.

Beetham, David and Kevin Boyle. Auditing Democracy in Britain: The Democratic Audit of the United Kingdom (Democratic Audit Paper). London: Charter 88, 1993.

Breyer, Stephen G. Making Our Democracy Work: A Judge's View. New York: Vintage, 2011.

Crick, Bernard R. Democracy: A Very Short Introduction. Oxford: Oxford University Press, 2003.

Crick, Nathan. Democracy and Rhetoric: John Dewey on the Arts of Becoming. Columbia: University of South Carolina Press, 2010.

Dahl, Robert A. On Democracy. New Haven: Yale University Press, 2000.

Dahl, Robert A. Who Governs? Democracy and Power in an American City. 2nd ed. New Haven: Yale University Press, 2005.

Diamond, Larry Jay. The Spirit of Democracy: The Struggle to Build Free Societies throughout the World. New York: St. Martin's, 2008.

Diamond, Larry Jay, and Marc F. Plattner. Electoral Systems and Democracy. Baltimore: Johns Hopkins University Press, 2006. 
Dunn, John. Democracy: A History. New York: Atlantic Monthly Press, 2006.

Edwards, Mickey. The Parties versus the People: How to Turn Republicans and Democrats into Americans. New Haven: Yale University Press, 2012.

Ferguson, Adam. An Essay on the History of Civil Society (Cambridge Texts on the History of Politial Thought). Ed. Fania Oz-Salzberger. Cambridge: Cambridge University Press, 1996 [1767].

Forster. E. M. Two Cheers for Democracy. New York: Harcourt, 1951.

Held, David. Models of Democracy. 3rd ed. Cambridge: Polity Press, 2006.

Huxley, Aldous. Brave New World Revisited. New York: Harper, 2006 [1958].

Ivey, Bill. Hand-Making America: A Back-to-Basics Pathway to a Revitalized American Democracy. Berkeley: Counterpoint, 2012.

Judt, Tony. Ills Fares the Land. New York: Penguin, 2010.

Keane, John. The Life and Death of Democracy. New York: W. W. Norton, 2009.

Lipset, Seymour Martin. Political Man: The Social Bases of Politics. New York: Anchor, 1963.

Lipset, Seymour Martin, and Jason Lakin. The Democratic Century: Norman: University of Oklahoma Press, 2004.

Nisbet, Robert. The Quest for Community: A Study in the Ethics of Order and Freedom. Wilmington, DE: ISI Books, 2011 [1953].

Posner, Richard A. The Crisis of Capitalist Democracy. Cambridge, MA: Harvard University Press, 2011.

Putnam, Robert. Bowling Alone: The Collapse and Revival of American Community. New York: Simon and Schuster, 2001.

Putnam, Robert, with Robert Leonardi and Raffaella Y. Nonetti. Making Democracy Work: Civic Traditions in Modern Italy. Princeton: Princeton University Press, 1994.

Putnam, Robert, and Lewis M. Feldstein with Don Cohen. Better Together: Restoring the American Community. New York: Simon and Schuster, 2003.

Putnam, Robert, and David E. Campbell. American Grace: How Religion Divides and Unites Us. New York: Simon and Schuster, 2010.

Riesman, David, and Nathan Glazer and Reuel Denney. The Lonely Crowd, Revised Edition: A Study of the Changing American Character. New Haven: Yale University Press, 2001 [1950, 1967]. 
Sen, Amartya. The Idea of Justice. Cambridge, MA: Harvard University Press, 2011 [2009].

Skocpol, Theda, with Larry M. Bartels, Mickey Edwards, and Suzanne Mettler. Obama and America's Political Future. Alexis de Tocqueville Lectures on American Politics. Cambridge, MA: Harvard University Press, 2012.

Saco, Diana. Cybering Democracy: Public Space and the Internet. Minneapolis: University of Minnesota Press, 2002.

Surowiecki, James. The Wisdom of Crowds. New York: Random House, 2004.

Tilly, Charles. Democracy. Cambridge: Cambridge University Press, 2007.

Todd, Emmanuel. After the Empire. Trans. C. Jon Delogu. New York: Columbia University Press, 2003.

Wolin, Sheldon S. Democracy Incorporated: Managed Democracy and the Specter of Inverted Totalitarianism. Princeton: Princeton University Press, 2008.

Wolin, Sheldon S. Politics and Vision: Continuity and Innovation in Western Political Thought, Princeton: Princeton University Press, 2004 expanded edition [1960]. 

Tocqueville and Democracy in the Internet Age is an introduction to Alexis de Tocqueville (1805-1859) and his monumental two-volume study Democracy in America $(1835,1840)$ that pays particular attention to the critical conversation around Toqueville and democracy since the end of the Cold War during the Internet Age. The book is addressed broadly to beginning students, specialists, and ordinary curious people who wonder if democracy is still possible today and under what conditions.

\begin{abstract}
"Jon Delogu's Tocqueville and Democracy in the Internet Age astutely connects many of the current issues surrounding the present and possible future states of 'democracy' in the U.S., France, and the world. The author not only makes a convincing case for the relevance of Toqueville and democracy in the 'Internet age' but also demonstrates a command of Democracy in America and the enormous body of criticism and commentary on it."

- William Dow, Professor of American Literature and American Studies, American University of Paris, Université Paris-Est MLV
\end{abstract}

C. Jon Delogu is currently Professeur des Universités in the Department of English at the Université Jean Moulin, Lyon 3 in France. He has been a teacher-researcher in France since 1992. He has also taught at Boston University, Connecticut College, Dartmouth College, Hampshire College, and the University of Southern Maine. He has translated five books for Columbia University Press and is the author of an introduction to Emerson in French.

Cover from a design by Daniel Delogu

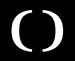

